Department of Social Security

Research Report No. 46

\title{
Social Assistance in OECD Countries
}

\author{
Volume!: Synthesis Report
}

A study carried out on behalf of the Department of Social Security and the OECD by the Social Policy Research Unit

\author{
Tony Eardley \\ Jonathan Bradshaw \\ John Ditch \\ lan Gough \\ Peter Whiteford
}


Crown copyright 1996

Applications for reproduction should be made to HMSO Copyright Unit First published 1996

ISBN 0117624071

ISSN 09615695

Views expressed in this report are not necessarily those of the DSS or any other government department, the OECD or any member countries of the OECD.

\section{.A full list of other publications in this series is shown on page 195}

\section{HMSO}

Standing order service

Placin ${ }^{\mathrm{g}}$ a standing order with HMSO BOOKS enables a customer to receive future titles in this series automatically as published. This saves the time, trouble and expense of placing individual orders and avoids the problem of knowing when to do so, For details please write to HMSO BOOKS (Standing Order Section), Publications Centre. APO Box 276 London SW8 5DT quotin ${ }^{\mathrm{g}}$ reference 2402058.

The standing order service also enables customers to receive automatically as published all material of their choice which additionally saves extensive catalogue research. The scope and selectivity of the service has been extended by new techniques. and there are more than 3,500 classifications to choose from. A special leaflet describing the service in detail may be obtained on request. 


\section{Contents}

Preface

Acknowledgements

List of Tables and Figures

Executive Summary

Chapter I

Introduction

$.1 \quad$ Objectives

1.2 Research methods

Purchasing power parities

A pproaches to comparative research

L3 Why study social assistance?

1.4 The structure of the report

Chapter 2 Social Assistance across the OECD: Patterns and Trends

2.1 A taxonomy of social assistance 26

2.2 Expenditure on social assistance $\quad 32$

2.3 Recipients of social assistance $\quad 38$

Types of assistance benef cicary

Changes in assistance populations over time

$\begin{array}{lll}2.4 \text { Conclusion } & 46\end{array}$

Chapter $3 \quad$ The Structure and Principles of Social Assistance Schemes

3.1 Introduction $\quad 47$

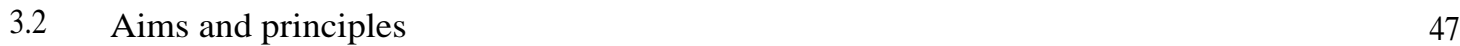

$\begin{array}{ll}3.3 & \text { Conditions of eligibility }\end{array}$

3.4 Inclusion and exclusion $\quad 59$ Minimum age thresholds

Residence and nationality conditions

$\begin{array}{ll}3.5 & \text { Conditions of entitlement } \\ \end{array}$ $\begin{array}{ll}\text { Benefit tend resource units } & 65\end{array}$

The treatment of resources

$\begin{array}{lll}3.6 & \text { Housing costs } & 67\end{array}$

$\begin{array}{lll}3.7 & \text { Meeting urgent or exceptional needs } & 71\end{array}$

$\begin{array}{lll}3.8 & \text { Conclusion } & 78\end{array}$

Chapter $4 \quad$ Administration and Delivery of Social Assistance Benefits

4.1 Introduction $\quad 80$

$\begin{array}{lll}4.2 & \text { Centre-local responsibilities } & 80\end{array}$

4.3 Making a claim and receiving a payment $\quad 82$

$\begin{array}{lll}4.4 & \text { Procedures for verification of identity } & 88\end{array}$

$\begin{array}{lll}4.5 & \text { Computerisation of benefit delivery } & 88\end{array}$

4.6 Fraud prevention and control $\quad 88$ 
$\begin{array}{lll}4.7 & \text { Recovery of overpayments } & 92\end{array}$

4.8 Provision for payment of benefit to third parties 92

4.9 The role of social workers $\quad 93$

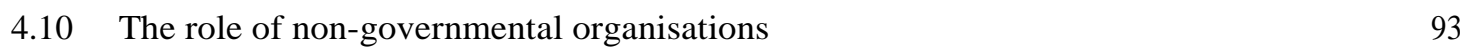

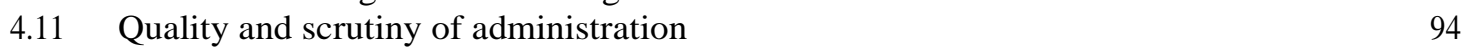

$\begin{array}{ll}4.12 \text { Conclusion } & 95\end{array}$

Chapter $5 \quad$ Benefit Rates, Adequacy- and Take-Up: National Debates 96

$\begin{array}{ll}5.1 & \text { Introduction }\end{array}$

5.2 The construction of social assistance scales 96

5.3 Debates about poverty and the level of benefits 101

The role of non-governmental organisations and poverty lobbies' 103

Debates about adequacy of assistance payments 104

5.4 Take-up of means-tested benefits 106

$\begin{array}{llr}5.5 & \text { Conclusion } & 108\end{array}$

Chapter 6 The Level and Structure of Social Assistance Payments

$\begin{array}{llr}6.1 & \text { Introduction } & 109\end{array}$

$\begin{array}{lr}6.2 \text { Methods } & 109\end{array}$

Housing costs $\quad 112$

$\begin{array}{ll}\text { Local taxes } & 115\end{array}$

$\begin{array}{ll}\text { Health costs } & 115\end{array}$

School and child-care costs $\quad 116$

6.3 Limitations of the model family approach 116

$\begin{array}{ll}\text { Purchasing power parities } & 117\end{array}$

$\begin{array}{lll}6.4 & \text { The results of the income matrix analysis } & 117\end{array}$

$\begin{array}{ll}\text { The structure of social assistance } & 117\end{array}$

$\begin{array}{ll}\text { Social assistance levels } & 124\end{array}$

6.5 Conclusion $\quad 137$

Chapter $7 \quad$ Social Assistance, Work and Incentives 140

$\begin{array}{llr}7.1 & \text { Introduction } & 140\end{array}$

$\begin{array}{lll}7.2 & \text { Background data } & 141\end{array}$

$\begin{array}{lll}7.3 & \text { Duration of assistance } & 143\end{array}$

$\begin{array}{lll}7.4 & \text { Job search requirements } & 147\end{array}$

$\begin{array}{lll}7.5 & \text { Income tests and related arrangements } & 153\end{array}$

$\begin{array}{lll}7.6 & \text { Benefit replacement rates } & 157\end{array}$

$\begin{array}{lll}7.7 & \text { Average effective tax rates and the poverty trap } & 161\end{array}$

$\begin{array}{lll}7.8 & \text { Conclusion } & 163\end{array}$

Chapter $8 \quad$ Diverse Systems, Common Destination? 165

$\begin{array}{llr}8.1 & \text { Introduction } & 165\end{array}$

8.2 Patterns of social assistance 165

$\begin{array}{lll}8.3 & \text { Debates and policy initiatives } & 171\end{array}$

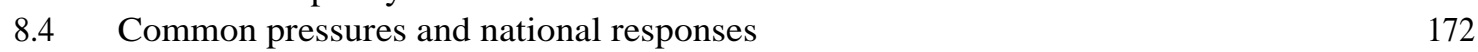

New demands from external forces 172

Pressures from within the policy systems

Unemployment and work incentives $\quad 174$

\begin{tabular}{ll}
8.5 & Evaluating national assistance regimes \\
\hline
\end{tabular}

$\begin{array}{ll}8.6 \text { Conclusion } & 178\end{array}$

$\begin{array}{lr}\text { References } & 180\end{array}$ 


\section{Preface}

This study was initially commissioned in October 1993 by the UK Department of Social Security, to inform its understanding of social assistance schemes in the member states of the European Union and a number of other relevant countries. The original proposal was to include in the study the then 12 countries of the European Union, plus Norway and Sweden as likely future members. together with the English-speaking group of developed countries consisting of the USA. Canada. Australia and New Zealand. In the course of initial information gathering, contact was made with the Social Policy Division of the Organisation for Economic Cooperation and Development (OECD). They expressed interest in the research being extended to the six member countries not already covered by the study and after consultations between the two sponsoring bodies, and with the six member governments, a further contract was agreed. Shortly after the research was commissioned it was discovered that Professor Ian Gough of the University of Manchester had received a social science fellowship from the Nuffield Foundation to pursue $a$ similar study, on a smaller scale but including some of the non-EU countries. Once the OECD participation was confirmed it was agreed that it would be mutually beneficial for the two projects to co-operate.

The results of the research are presented in two volumes. The second volume presents separate country-by-country descriptions of assistance schemes and their place within social security more widely, with trend data on claimant numbers and expenditure and brief discussions of policy issues current in each country. This volume provides a synthesis of comparative and analytical material organised by themes.

Any views expressed are those of the authors and do not necessarily reflect those of participating ${ }^{\mathrm{g}}$ overnments, nor those of either the UK Department of Social Security or the OECD.

University of York

August 1995 


\title{
Acknowledgements
}

We are grateful to the Department of Social Security and the OECD for funding this research, and to the Nuffield Foundation. who supported Ian Gough`s participation in the study.

This study is the result of collaborative effort going well beyond the research team itself_ It is primarily based on information provided by two networks of national informants working in their own countries. The government officials listed below either completed questionnaires themselves or acted as co-ordinators of information collected from different sections of the administration. Many of them undertook this task with energy and enthusiasm, for which we are most grateful. The academic experts, and their colleagues, provided information. commentary and access to a wealth of research studies on social assistance in their own countries. They also commented on our drafts and engaged with us in a continuous process of dialogue to improve and refine our understanding of national systems and policies. It has been an immensely valuable process, and while the responsibility for any errors or misinterpretations remains with the authors, the study would not have been possible without the knowledge, enthusiasm and hard work that the national informants contributed, for only modest rewards.

\author{
Australia \\ Ms Lynelle Briggs \\ Ms Fiona Smart \\ Social Policy Division \\ Department of Social Security
}

\section{Austria}

Mr Hans Steiner

Ministry of Labour and Social Affairs

Dr Walter Pfeil

Institute for Social and Labour Law

University of Salzburg

Belgium

Mr 3. Donis

International Relations

Ministry of Social Security

Mark Andries

Professor Bea Cantillon

Centre for Social Policy

University of Antwerp

\section{Canada}

Mr Gilles Seguin

Social Policy Information and Analysis Directorate

Human Resources Development Canada

Professor Patricia Evans

School of Social Work

York University

Ontario 


\section{Denmark}

Mr Per Hansen

Ministry of Social Affairs

Dr Peter Abrahamson

Department of Economics and Planning

Roskilde University

\section{Finland}

Ms Use Julkunen

Professor Hannu Uusitalo

National Research and Development Centre for Welfare and Health

Helsinki

\section{France}

Mr Antoine Math

Caisse Nationale des Allocations Familiales

Dr. Eliane Jankeliovitch-Laval

Faculty of Law and Economic Sciences

University of Nancy II

\section{Germany}

Dr Manfred Wienand

Deutscher Verein fair offentlichc and private Fiirsorge

Dr Bernd Schulte

Max-Planck Institute for Foreign and International Social Law

\section{Greece}

Mrs N. Nikolopoulou

General Directorate of Welfare

Ministry of Health. Welfare and Social Security

Mr Theodoros Papadopoulos

Department of Social Policy and Social Work

University of York

\section{Iceland}

l.ngibjorg Brodatottir

Ministry of Social Affairs

Ms Majella Kilkey

Department of Social Policy and Social Work

University of York

\section{Ireland}

Ms Anne McManus

Planning Unit

Department of Social Welfare

Italy

No ${ }^{\mathrm{n}}$ official response

Professor Angelo Saporiti

Department of Economic and Social Sciences

University of Campobasso

\section{Japan}

Mr Hidekazu Inegawa

Japanese Delegation to the OECD

Professor Minoru Abe

Japanese School of Social Work

Tokyo 
Professor Takafumi Uzuhashi

Department of Economics

Osaka Sangyo University

\section{Luxembourg}

Mr Claude Ewen

Inspectorate-General for Social Security

Ministry of Social Security

Dr Alain Wagner

Mr Koen Vleminckx

Centre for Studies of Populations, Poverty and

Political Economy (CEPS/INSTEAD)

Netherlands

Mr No Van Der Steen

Mr Mat Nacinovic

Ministry for Social Affairs and Employment

Dr Wim van Oorschot

Tilburg Institute of Social Security Studies

Catholic University of Brabant

New Zealand

Mr David Preston

Mr Don Gray

Social Policy Agency

Department of Social Welfare

Dr Robert Stevens

Faculty of Commerce and Administration

Victoria University of Wellington

\section{Norway}

Mr Knut Brofoss

Department of Social Affairs

Dr Lars-Inge Terum

Institute for Applied Social Studies (INAS)

Oslo

\section{Portugal}

Ms Sara Cardi ${ }^{\mathrm{g}}$ os

Directorate-General for Social Security

Ministry of Labour and Social Security

Dr Alfredo Brut() da Costa

Department of Economics and Planning

University of Lisbon

\section{Spain}

Dr Teresa Guardia

Subdirectorate-General for Research, Statistics and Publications Ministry of Social Affairs

'_VIr Joaquim Aguabella

Dr Jordi Estivill

Office for Social Studies

Barcelona

\section{Sweden}

Mr Jonas Wiklund

National Board of Health and Welfare 
Dr Joakim Palme

Swedish Institute for Social Research

Stockholm

Switzerland

Mr C. Malherbe-

International relations

Federal Office of Social Insurance

Dr Marie-Luce Guillaume

Department of Political Economy

Fribourg University

Turkey

Mr final

Social Insurance Institute

Dr lstar Gozaydin

Faculty of Law

University of Istanbul

United Kingdom

Mr Bruce Reveley

Department of Social Security

\section{United States}

Dr David Ellwood

Mr Bill Prosser

Department of Health and Human Services

Professors Sheila Kamerman and Alfred Kahn

Columbia University School of Social Work

New York

In addition to these, Peter Whiteford acted as the informant for Australia, John Ditch for Ireland and Tony Eardley for the UK.

The study has benefited from the suggestions and comments of policy makers in the Department of Social Security. including Owen Thorpe and Bruce Reveley. of Peter Scherer, Patrick Hennessy and Mark Pearson at the OECD, and of Roland Sigg from the International Social Security Association (ISSA).

We are also grateful for comments and suggestions from our liaison officers at the Department of Social Security. Julia Chilvers and Daniel Murphy, as well as for their support and encouragement.

Finally, the study would have been immeasurably more difficult without the input of a number of other people. Maureen Astin entered the model family matrix data on to the database and undertook initial analyses. Fran Bennett contributed substantially to the UK chapter in Volume Two. Helen Barnes, Joanna Coles. Sarah Dewson and Nina Oldfield also helped with drafting or revising several chapters in Volume Two. Michaela Schunk,from the University of Manchester, provided extra data on Germany. Carol Chaundy drew up a glossary and database of benefit names and descriptions. and with Tom Stimson provided essential research assistance.

Sally Pulleyn, with the help of Teresa Anderson and Helen Jacobs, undertook the job of typing and formatting a huge and complex text with her usual skill and grace under pressure. Lorna Foster proof read much of the text and made useful editorial suggestions. 


\section{Lists of Tables and Figures}

Page

Tables

Table 2.1: A taxonomy of national resource-tested assistance program mes (1992)

Table 2.2: Total assistance expenditure in 1990.91 as a percentage of G.DP. social protection and social security

Table 2.3: $\quad$ Social assistance expenditure as a percentage of Gross

Domestic Product (GDP), 1992

Table 2.4: Cash social assistance as a proportion of GDP. 1980--92

Table 2.5: Total social assistance expenditure as a proportion of social security. $1980-1992$

Table 2.6: Individuals (including children) in families receiving social assistance in 1992, as a percentage of total national populations

Table 2.7: Individual beneficiaries of cash assistance. as a percentage of national populations. $1980-1992$

Table 2.8: $\quad$ Main categories of social assistance beneficiaries, 1992

Table 2.9: Definitions and sources of data for categorical schemes in Table 2.8

Table 2.10: Changes in main categories of beneficiaries. 1980-1992

Table 3.1: Main conditions of eligibility for income-related and meanstested benefits in the OECD countries

Table 3.2: Conditions of entitlement to the main assistance benefits

Table 3.3: Means-tested help with housing costs

Table 3.4: Methods of meeting urgent and one-off needs

Table 4.1: Chiming social assistance, verification and fraud control

Table 4.2: $\quad$ Procedures for recovery of overpayments, appeals and scrutiny of administration

Table 5.1: Mechanisms for setting and uprating social assistance benefits

Table 5.2: Views on the adequacy of social assistance 
Table 6.1: Gross rents nominated by the national informants in purchasing power parity. $£$ sterling and USS. per month, 1992

Table 6.2a: Structure of the social assistance package. Couple aged 35 Amounts per month in $£$ and S PPPs (before housing costs), 1992

Table 6.2b: $\quad$ Structure of the social assistance package. Couple aged 35 . Amounts per month in $£$ and S PPPs (after housing costs), 1992

Table 6.3: $\quad$ Structure of the social assistance package. Couple aged 68. Amounts per month in E. and S PPPs (after housing costs), 1992

Table 6.4: $\quad$ Structure of the social assistance package. $\mathrm{C}=$ ouple aged $35+$ two children $(7,14)$. Amounts per month in $£$ and S PPPs (after housing costs). 1992

Table 6.5a: Families on social assistance: net disposable income (£ sterling purchasing power parity) per month (before housing costs), 1992

Table 6.5b: Families on social assistance: net disposable income ( $£$ sterling purchasing power parity) per month (after housing costs), 1992

Table 6.6a: Implied equivalence scale of social assistance (before housing costs), couple (35) ${ }^{\mathrm{mim}} 100,1992$

Table 6.6b: Implied equivalence scale of social assistance (after housing costs), couple (35) $\quad 100,1992$

Table 6.7a: Social assistance: percentage difference from the mean - all cases before housing costs

Table 6.7b: Social assistance: percentage difference from the mean - all cases after housing costs

Table 6.8a: Pensioners replacement ratio (net disposable income on social assistance as percentage of net disposable income on average earnings) (before housing costs)

Table 6.8b: Pensioners replacement ratio (net disposable income on social assistance as percentage of net disposable income on average earnings) (after housing costs)

Table 6.9a: Ratio of net disposable income on social assistance to net disposable income on social insurance (before housing costs)

Table 6.9b: Ratio of net disposable income on social assistance to net disposable income on social insurance (after housing costs)

Table 6.10: Changes in social assistance which might have affected the level of payments between 1992 and 1995

Table A6.1: Gross average male earnings per month, May 1992 
Table A6.2: Purchasing power parities and exchange rates $(\mathrm{UK}=1.00)$, May 1992

Table A6.3: Social assistance (before housing costs) as percentage of average gross earnings, 1992

Table 7.1: $\quad$ Selected labour force statistics for OECD countries, 1992

Table 7.2: Duration conditions in social insurance and social assistance schemes, 1994

Table 7.3: $\quad$ Measured duration of receipt of social assistance benefits for selected countries

Table 7.4: job search requirements in social assistance schemes, OECD countries, 1994

Table 7.5: Disregards and income tests in social assistance schemes, 1994

Table 7.6a: Replacement ratio: social assistance as percentage of net disposable income at average earnings, OECD countries 1992 (before housing costs)

Table 7.6b: Replacement ratio: social assistance as percentage of net disposable income at average earnings, OECD countries 1992 (after housing costs)

Table 7.7a: Average effective tax rates for social assistance recipients moving into work on average earnings, OECD countries. 1992 (before housin $^{\mathrm{g}}$ costs)

Table $7.7 \mathrm{~b}$ : Average effective tax rates for social assistance recipients moving into work on average earnings. OECD countries, 1992 (after housing costs)

Table 8.1: $\quad$ Selected features of social assistance systems

\section{Figures}

Figure 2.1: A taxonomy of means-tested schemes

Figure 8.1: A typology of extent and generosity of social assistance 


\title{
Executive Summary
}

\author{
Chapter L Introduction
}

\section{Objectives}

The study is concerned with the ways in which countries provide a guarantee of minimum resources to residents who lack sufficient income from other sources. The research was commissioned originally by the UK Department of Social Security to cover the then 12 member countries of the European Union, plus Australia, Canada, Norway, New Zealand. Sweden and the USA (taking four states as examples). The Organisation for Economic Co-operation and Development (OECD) provided additional funding for the study to be extended to the remaining six OECD member countries (Austria. Finland. Iceland. Japan, Switzerland and Turkey).

'Social assistance' does not have a precise definition internationally. For the purposes of the study, it is defined as the range of benefits and services available to guarantee a minimum (however defined) level of subsistence to people in need, based on a test of resources. In some countries a key element of the social safety net comes through non-contributory citizens' benefits or pensions. These are not discussed in detail unless they are also resource-tested.

The study also distinguishes between benefits described as 'poverty-tested' (that is, aimed at providing a minimum income. which is often regarded as a de facto poverty line) and other income-related or means-tested benefits which may have a different purpose, or are withdrawn at a higher income level.

The aims of the study were:

- to provide detailed country-by-country descriptions of the structure of social assistance schemes, with data on expenditure and claimant numbers, recent policy developments and proposals. and an assessment of overall performance. This information is provided mainly in Volume Two

- to provide a comparative analysis of trend data: the legal and administrative structures of assistance schemes; and policy debates and issues affecting the development of social assistance

- to analyse the comparative value of assistance payments, their components and their implicit incentive structures.

Specific issues to be addressed included:

- conditions of entitlement

- coverage

- benefit levels

- $\quad$ operation of means tests

- administration, regulation and finance

- fraud control

- $\quad$ emergency and lump-sum payments

- $\quad$ benefits in kind. 'passported' benefits and exemptions 
- help with housing costs

- the relationship between means-tested and other benefits

- the role of non-governmental or ${ }^{\mathrm{g}}$ anisations and 'poverty lobbies'.

Research methods'

Research was carried out using two networks of national informants. one consisting of senior officials in national ministries and agencies, and the other of experts recruited from universities or independent research institutes. The latter completed a 'model family income matrix'. to allow comparison of the value of assistance benefts, both between countries and within them in relation to insurance benefits and earnings.

Information obtained from the two networks was put in context by reviewing national and comparative literature on social assistance, poverty and income distribution.

Purchasing power parities (PPPs) were used in the comparison of expenditure and to assess the relative value of benefits across countries. PPPs have some limitations, but are generally seen to be a more satisfactory measure than exchange rates.

Within different classifications of approaches to comparative research, the study can be seen as primarily a 'system-by-system ${ }^{\circ}$ analysis (Hauser. 1993). or a 'micro study of policy inputs' (Bradshaw, 1994).

Why study social assistance?

There is ${ }^{\mathrm{g}}$ rowing international interest in selective and targeted approaches to social protection. Research has identified substantial levels of 'new poverty' in EL member countries, partly related to limitations in insurance-based protection in the context of long-term unemployment and social change. The view that high levels of social security expenditure damage economic effort has also become more influential internationally, and financial institutions working in the transitional economies of Eastern Europe have been calling for the establishment of meanstested safety nets as a key element in anti-poverty strategies.

There is a need to understand to what extent reliance on assistance has been increasing. what patterns have emerged in how schemes are organised, and how successful policy approaches to common problems have been. Some previous research has been carried out comparing social assistance schemes in selected countries, but no studies have been mounted on the scale reported here.

\section{Chapter 2. Social assistance across the OECD: patterns and trends}

A taxonomy c social assistance

There are three basic mechanisms by which the state can directly allocate income or services to individuals or households:

'universal' or contingency benefits, not related to income or employment status, allocated to all citizens within a certain social category

(B) social insurance, where the benefit is related to employment status and contributions paid

- means-tested or income-related benefits, where eligibility is dependent upon the current or recent resources of the beneficiary.

Within resource-tested programmes, the study makes three distinctions:

- between 'poverty-tested' benefits, and 'general means- or income-tested benefits'. The latter may go to people well above any poverty line 
- between 'cash' and 'tied' benefits. The latter cover reductions in costs for specific services. the most important of which is housing

( ) between schemes open to all people within a certain income group and those for specific categories. such as older or disabled people.

The study concentrates on benefits aimed at guaranteeing minimum incomes, but the structures of benefit in countries like Australia and New Zealand_which extend beyond the poverty line_ require also the inclusion of benefits performing similar functions in the U.K, the USA and some other European countries. 'Social assistance' in the report therefore includes:

- general assistance providing cash benefits for all or most people below a specified minimum income level

- categorical assistance - providing cash benefits for specific groups (sometimes at a level above the minimum)

(B) tied assistance - providing free or subsidised access to specific goods or services. either in kind or in cash. This is further divided into housing assistance and other tied assistance.

\section{Expenditure on social assistance}

Data on social assistance expenditure are problematic: definitions of what constitutes social assistance expenditure vary and accurate national estimates are not always available. Estimates are presented of expenditure on social assistance as proportions of GDP. 'social protection' and 'social security' (as estimated by the OECD).

As a proportion of GDP, total spending on social assistance in 1992 ranged from 0.1 per cent in Greece. which has no general assistance scheme, to 13 per cent in New Zealand, where virtually all benefits are resource-tested. Categorical assistance for specific groups is more important than general programmes in most continental EU member countries. while housin ${ }^{\mathrm{g}}$ assistance is particularly important in the UK, France and Sweden.

All types of welfare re ${ }^{\mathrm{g}_{i m e}}$ exhibited a rising share of expenditure on means-tested schemes in the 1980s -- a notable convergence of otherwise disparate national patterns. Proportionately, the fastest growth in spending took place in the Nordic countries. though from a low base. Only Japan and Switzerland appear not to have spent a higher proportion of overall social security spending on social assistance between 1980 and 1992.

\section{Recipients of social assistance}

Comparative estimates of the number of people receiving social assistance are also problematic_for reasons similar to those for expenditure. Estimates are given of the total numbers of beneficiaries (including dependants) as a proportion of total populations.

Overall. the English-speaking countries operate the most extensive social assistance programmes. Those with the Iowest numbers receiving assistance include Greece. Japan. Portugal, Spain and Switzerland. In terms of general unified assistance schemes, the UK stands out. delivering Income Support to more than 15 per cent of the population in 1992. When categorical schemes are included. Australia and New Zealand predominate, and Ireland also joins the high-coverage group.

The majority of countries recorded a substantial expansion in beneficiary populations between 1980 and 1992, particularly the UK. Canada. Ireland, Germany and the Nordic countries. The proportionate increase was greatest in the Scandinavian countries (except Sweden, though numbers there have ${ }^{\mathrm{g}}$ rown rapidly since 1992). 
Data breaking down recipients into comparable categories are particularly difficult to obtain. However, generally speaking, old age is a diminishing reason for people to claim means-tested benefits. both in absolute and relative terms. All countries except Japan appear to have a growing demand for assistance payments on the basis of disability. partly because of more generous provision and partly, in some countries, as a substitute for inadequate unemployment protection.

Lone parents make up a disproportionate and growing proportion of the claimant population in many countries, though lone parents' likelihood of being on social assistance is linked to other policies on labour market participation and to the existence of other forms of special provision.

Despite sparse data. unemployment (especially long-term unemployment) appears overall to be the principal cause of the rising social assistance clientele since 1980, especially in the English-speaking countries, except the USA.

In most countries, between half and two-third of claimants are single people, and only around one-third on average have children. Benefit units headed by women, including lone mothers and single women, make up between one-third and 60 per cent of recipients overall.

\section{Chapter 3. The structure and principles of social assistance schemes}

Chapter Three compares the structure of the benefits and the rules governing eligibility and entitlement. It considers how far common principles and practices can be discerned across the schemes.

Issues examined include:

- $\quad$ underlying principles

- conditions of eligibility

$\mathrm{t}$ conditions of entitlement and resource testing

- $\quad$ help with housing costs

- $\quad$ meeting exceptional needs.

Although the basic principles informing different schemes are not dissimilar, the realisation of these principles in practical policy varies considerably. The first major distinction is whether minimum income guarantees are provided across the board, through a generalised scheme, or whether people's needs are addressed within different categorical population groups. At present, the preference of the majority of countries is still to offer protection by category.

The minimum age threshold for most general schemes is 18 years, unless young people have or are about to have children_ or face particular hardship.

More than half the countries studied have some prior residence conditions, as well as limiting the availability of help for refugees and asylum seekers.

Most countries take into account only the resources of the claimant, and the partner in the case of couples. In a few countries, however, expectations of family support extend further, at least in principle. These include Austria, Germany. Japan and Switzerland. By contrast. a small number of countries. mainly in the Nordic ${ }^{\mathrm{g}}$ roup, do not always take into account the resources of a cohabiting partner unless the couple are married.

There is also wide variation in the level and type of earnings, other income and assets discounted in the means test, though most take into account child maintenance payments. Overall. the strictest means tests are found in the Scandinavian countries, plus Austria and Switzerland. 
The various combinations of approaches to means-testing can sometimes appear paradoxical. For example, the Nordic countries tend to combine strict means tests with liberal approaches to cohabitation rules, while countries like Austria and Switzerland may expect claimants to seek support from their wider family, but still offer relatively generous benefits. These paradoxes can partly be explained by looking at different countries' traditions, in terms of expectations of family support, the emphasis placed on work incentives, their attitudes to cohabitation and lone parenthood and the relative importance of assistance schemes in the wider income maintenance systems.

As regards approaches to the benefit and resources unit, it is interesting to note the relative uniformity. With a number of exceptions where wider family obligations have retained a strong legal foundation. the nuclear family is the norm, in spite of some tentative moves towards forms of individualisation. Efforts to shift obligation back on to the wider family seem to be unsuccessful where it has been attempted.

Most countries meet some or all of the housing costs of people with incomes low enough to receive social assistance, usually including owner-occupiers as well as tenants. The main distinction is between those countries which provide help as part of a general social assistance payment (and only for assistance recipients) and those with a general housing benefit scheme open to people on low incomes generally.

Virtually all countries have some arrangements for meeting exceptional needs, through combinations of loans and grants. These are frequently discretionary, but the level of debate generated by such provision in the UK appears to be exceptional.

\section{Chapter 4. Administration and delivery of social assistance benefits}

\section{Centre-local responsibilities}

All social assistance schemes have complex administrative structures, but there are important differences between countries in how benefits are organised and delivered. The main contrast is between countries like Australia and the UK, which have integrated and national schemes with common rules of eligibility and payment levels, and those such as Italy, Norway and Switzerland, where both administrative responsibility and decisions about levels of benefit payable are devolved almost entirely to the local level.

Some of the latter countries face a dilemma: it is usually those regions or local authorities with the lowest potential funding capacity which have the highest demand on social assistance. In these countries, funding is generally split proportionately between central and local governments. Outside the centrallyorganised systems, the trend is towards greater devolvement of powers towards regional or local authorities and reductions or restraint in central funding. The new funding structure set to replace the Canada Assistance Plan from .1996 provides a key example. On the other hand, there is also pressure in several of the Scandinavian countries in particular, and in Switzerland to a lesser extent, for greater national standardisation of benefit levels.

The chapter compares arrangements for the administration and delivery of benefit as follows:

- making a claim and receiving a payment

- $\quad$ procedures for verification of identity

- computerisation of benefit delivery

- $\quad$ fraud prevention and control

- recovery of overpayments

- $\quad$ provision for payment of benefit to third parties 
$\mathrm{S}$ the role of social workers

$\mathrm{S}$ the role of non-governmental organisations

S quality and scrutiny of administration.

Of necessity, all social assistance schemes are complex. as they seek to adjust to the diverse and changing needs of claimants on the one hand and the interests of tax payers and employers on the other. Aspects of the administrative process. such as methods of application and payment, reporting requirements on claimants and recovery of overpayments, seem, at least in principle. broadly similar in most countries. There is considerable disparity in the extent to which fraud and abuse are regarded as serious problems in social assistance. and in the measures adopted to administer it. This variation correlates broadly to the size of assistance schemes. In the larger, centralised systems such as in Australia and new Zealand, increasing use is made of sophisticated computer data-matching technology. but even in the smaller schemes in Scandinavia and elsewhere_ assistance authorities have considerable access to other databases.

More research needs to be undertaken looking in detail at the practicalities of administration 'on the ground' in the different countries, in order to understand the role of administration and benefit delivery in the translation of policy objectives into outcomes.

\section{Chapter 5. Benefit rates, adequacy and take-up: national debates}

\section{The construction of social assistance scales}

In more than half the countries studied benefit rates are set nationally, whether social assistance is locally administered or not. Austria, Canada, Norway, Spain and :Italy (for the local Minima Vitale) are the only countries where both administration and the setting of rates are entirely the responsibility of the provinces or municipalities.

In most countries, uprating of benefits takes place annually, though in a few it takes place more often. Benefits are most commonly uprated in line with movements in the consumer prices index. Exceptions include Austria, Denmark and Finland. where benefits are linked to an earnings index or another benefit: and Germany-, which uses an index of the expenditure of the lower third of the income distribution. The formula used for uprating is not necessarily related to the way benefits were set in the first place.

\section{Debates about poverty and the level of benefits}

How much poverty is debated as an issue varies between countries. Factors which influence the level of debate include the extent to which recent economic problems have resulted in noticeable increases in deprivation, and the effectiveness of political parties or lobby groups at drawing public attention to the issues. There is not necessarily a correlation, however, between intensity of debates on poverty and actual levels of either absolute poverty or inequality.

Debates within the EU member countries have often focused on 'new poverty' identified with certain population groups amongst whom poverty has become more prevalent as a result of recession, social and demographic change and labour market restructuring. Emphasis on economic poverty is often seen as too narrow an approach, however. 'Social exclusion' is regarded as better capturing the broader deprivation which can result from inability to participate in the mainstream life of the citizen. It implies that effective action should encompass more than simply cash income maintenance.

In southern Europe debate has mainly focused on developing guaranteed minimum incomes in line with other EU countries, though discussion has tended to founder on the economic practicalities of such provision. 
The terms of debate have been somewhat different in the Scandinavian countries, where concern has been largely about inequality rather than poverty as such. In both Norway and Sweden, arguments have centred on the advantages of uniform national rates and regulation versus local and individualised discretion.

A theme which has been particularly salient in the USA, and to a lesser extent in the UK. has been that of benefit dependency and work incentives. In both countries assistance benefits are central to their systems of social protection. The 'underclass' debate has also had some resonance in the other English-speaking countries.

The Labor Government in Australia has been engaged in a high profile 'Social Justice Strategy', of which income support benefits are a key element. This includes concentrating resources on lower income families, in order to combat child poverty, through a combination of increased payments and tighter eligibility criteria. This was also one of the aims of the UK's benefit reforms in 1988, but one key difference has been the establishment in Australia of an official working party to research benchmarks of adequacy for benefit payments. By contrast, debate on poverty in New Zealand has been revived as a result of policies of economic liberalisation_involving direct and substantial reductions in some benefits and increases in charges for services.

The existence of organised campaigns and lobby groups appears to be one important element in whether poverty and social assistance are matters of public debate, even though these groups are often judged to have only limited influence. There are some distinctions between countries in terms of whether 'poverty lobbies' consist primarily of secular welfare rights organisations, often dependent on central or local government for funding, or whether the leading role is played by churchbased groups and charities.

Whether benefits are adequate is largely a subjective question. and the extent of research both on measures of adequacy and on views and attitudes varies considerably across countries. The chapter summarises in tabular form the limited information available for different countries. In most countries. the degree of debate about adequacy reflects to some extent the salience of social assistance in the social security system. Where social assistance is more important, it appears that there is more concern about adequacy and more information on the subject. These countries include. as well as Australia and the UK, Ireland. New Zealand and the USA. In those countries where social assistance levels are highly variable or locally determined. there is naturally more difficulty in examining the issue of adequacy.

\section{Take-up of means-tested benefits}

Whether or not benefit rates are considered to be sufficient to live on, means-tested benefits are only likely to be effective against poverty if people who are entitled to claim them do so. It has long been a criticism of means-tested benefits that take-up is often low compared to that for other types of benefit. Other research has suggested that, with the exception of in the UK, the non-take-up of social security benefits has been a particularly neglected topic. This observation was supported by the information provided by national informants for this study. Less than a quarter of the countries were able to provide any recent estimates of take-up and the basis of these was not always clear.

\section{Chapter 6. The level and structure of social assistance payments}

This chapter compares the level and structure of social assistance payments using the 'model family income matrix' data. 
This method draws on the technique developed in a previous study at the University of York on child support in 15 countries (Bradshaw et al,, 1993). Ten examples were chosen to illustrate the range of types of families that might be dependent on social assistance benefits. Information was collected on three benefit 'packages:

- $\quad$ social assistance - representing the 'worst case scenario' for all families

- $\quad$ social insurance --- representing the benefits payable if the model individuals and families were entitled to insurance-based unemployment benefits or pensions. under specified conditions

- the working case -- assuming that specified family members were working for average male production worker earnings.

Calculation of the packages required a common framework of analysis, with specification of:

- $\quad$ housing costs

- local taxes

- $\quad$ health costs

- $\quad$ education and child-care costs.

Housing costs are particularly problematic in comparative research, especially in relation to social assistance, which may or may not include elements for housing. The necessary assumptions made have to be borne in mind in interpreting the results of this analysis. In most analyses, results are presented both before and after housing costs.

\section{Limitations of the model family' approach}

There are several inevitable limitations to this method. It simulates how systems should work rather than how they actually do, and cannot include the behavioural effect of the policies simulated. The more assumptions are made about families in order to create comparability, the less representative they become of real populations. Also, for countries with locally- or individually- determined benefit rates, the figures used are the best estimates available of amounts payable in specified locations. They cannot necessarily be seen as representative of the countries as a whole.

The results of the income matrix analysis

Analysis of the structure of social assistance packages in May 1992 shows that for most countries recipients did not have to pay tax or social security contributions, but in about half they had to make small payments for health costs. In a number of countries additional 'tied' assistance payments were available, such as Food Stamps in the USA and an allowance for electricity in Ireland. Housing costs had a substantial impact, consuming a large element of social assistance payments in several countries, whereas in others, including the UK. recipients had little or no housing costs to pay.

Comparing the level of net disposable income at the social assistance level shows that for a couple with two children, the UK came 15th in the ranking of countries before housing costs and eighth after housing costs. Payments, after housing costs, ranged from $£ 21$ (533) per month, in purchasing power parities, in Portugal to $£ 544$ $(51,024)$ per month in Iceland.

Examination of the implied equivalence scales in social assistance shows that countries' relative position in a ranking changes for different family types. Most countries provided relatively larger assistance benefits to people over retirement age: Canada, France, Greece and the USA were notably more generous to people 
above retirement age. Some did not vary their social assistance payments between those below and above pension age, while a few countries appeared to pay higher benefits to working-age single people and couples than to pensioners. These differences did not appear to follow any obvious pattern, though they may be related to the level of benefits available from old-age insurance pensions.

There were also considerable variations in the ratios of payments to single people compared to couples. for children of different ages. and for lone parents compared to couples with children.

A composite ranking, based on percentages from the mean for nine family types, puts Iceland at the top, after housing costs, heading a group including the Nordic countries, Luxembourg, the Netherlands and Australia, all with levels more than 20 per cent above the mean. Next comes a group of countries led by the UK and including the USA (New York), Japan, France, Canada and Germany. Finally, there is a third group, all with social assistance levels more than ten per cent below the mean, including Belgium. New Zealand, the three other US states and the southern European countries.

Comparing the level of social assistance with average gross earnings, before housing costs, has the effect of improving the relative position of France, Finland and Sweden - all countries where average gross earnings are relatively low because high employer contributions constitute a deferred social wage.

Comparison with social insurance payments gives a picture of the contributions trap' for pensioners and illustrates the potential impact on family incomes when unemployment insurance runs out. Before housing costs, ratios varied considerably, both between countries and within countries by the type of family. Excluding Australia and New Zealand, which have no insurance benefits, the Nordic countries had particularly high ratios, followed by the UK and Ireland. After housing costs, ratios were generally higher because housing benefits are more generous to families on social assistance than on social insurance.

Overall, the highest levels of benefit appeared to be awarded in Switzerland (more specifically in Fribourg, since payments vary throughout the country), Luxembour $^{\mathrm{g}}$. the Netherlands, the Nordic countries and Australia. Among this group, the Nordic countries and Switzerland have common characteristics - they have relatively high levels of GDP, traditionally low levels of unemployment, and social assistance schemes which are residual and locally administered. They also all have strict means tests, while in the Nordic countries there are limited capital or earnings disregards and an emphasis on encouraging claimants to return to the labour market. These common features suggest that countries can sustain higher levels of social assistance provision when they support only a small number of claimants.

\section{Chapter 7. Social assistance, work and incentives}

This chapter provides an overview of features of social assistance arrangements which might influence labour supply behaviour, including how long people might be entitled to unemployment insurance, unemployment assistance and social assistance ${ }^{\mathrm{g}}$ enerally; job search activity tests and sanctions; insertion and integration programmes; and other incentives. Calculations are presented of replacement ratios and effective marginal tax rates.

Selected background labour force data are also given for the OECD countries in 1992. Unemployment rates ranged between 1.5 per cent in Luxembourg and just over 18 per cent in Spain. Since 1992 unemployment has fallen in most of the English-speaking countries and risen particularly in Finland, Sweden and Spain. Rates of long-term unemployment vary considerably and are not always correlated with the unemployment rate as a whole. 
Variations in conditions and coverage of unemployment insurance means that the percentages of assistance recipients who are unemployed and in the labour market also differ substantially between countries. Data are limited, but it is estimated that in 1992 the proportions varied from relatively few in Luxembourg and Portugal to about a third in the UK, half in Canada and Ireland, two thirds in the Netherlands and nearly all in Sweden. About two-thirds of social assistance recipients in the Nordic countries are young single persons who have not established an entitlement to insurance benefits. By contrast, in the UK, couples with children are the largest group of unemployed recipients of social assistance.

\section{Duration of assistance}

Entitlement to unemployment insurance can vary from none or a few months only. to indefinite periods for older workers in some countries. Belgium and the Netherlands appear to have the longest entitlement, if claimants have had sufficient recent employment. Duration of social assistance is generally unlimited where needs continue, except for specific benefits for young people in some countries. In Austria. Denmark, Italy, Spain (outside Madrid). Switzerland and Turkey. duration of payments is discretionary, and an assumption exists that assistance is intended only for limited periods.

Evidence on duration of receipt is patchy and not always comparable, but that available is presented in a table.

Job search requirements

In the majority of countries, recipients are required to register as unemployed and to establish that they are actively looking for work, unless exempted. In a few countries, the requirement to seek work is not a formal rule. but there are strong expectations that individuals will make full use of their capacities. Work tests can also be applied implicitly through the basic conditions of eligibility. In several states of the USA, for example, General Assistance is not available to able-bodied single people or couples without children.

In virtually all countries, work tests are less strict for people who are ill or disabled, or who are over or approaching retirement age. The major variations relate to lone parents. in particular to the age of children who exempt lone parents from the requirement to seek work. The most liberal provisions apply in Ireland. the United Kingdom, Australia and New Zealand. where lone parents are not required to seek work until their youn ${ }^{\mathrm{g}}$ est child is 16 years (or older). Requirements vary across provinces of Canada from the most restrictive (six months) to the more generous (12 years). Germany is also relatively liberal in this respect, as lone parents must normally seek part-time work when their youngest child is at school or in nursery education, and full-time work when the child is 14 or over. In Norway, lone parents receiving the Transitional Allowance are not required to seek work until the youngest child turns ten years of age. In Luxembourg and the Netherlands, the qualifying age is six years and five years respectively. In Austria and Finland, the qualifying age is three years. while in Sweden the age threshold is being liberalised from about 15 months to three years. In both Sweden and Denmark, however, which have the highest expectations that lone parents will seek work, municipalities are required to provide child care for lone parents seeking work. In France, expectations that lone parents receiving the RMI will engage in insertion activities vary between departements.

Most schemes have sanctions against claimants who fail to satisfy work tests. though it is not clear how often these are applied.

A range of work incentive schemes also operate in some countries, including disregards of income in the means-tests, lump-sum back-to-work allowances, and loans and grants for work expenses or self-employed business start-up. Municipalities are obliged to provide special employment schemes in Belgium. Denmark, Germany, the Netherlands, Norway, Spain and Sweden. 


\section{Benefit replacement rates}

Taking account of earnings disregards. replacement ratios were calculated for the model families, comparing disposable income on social assistance in 1992 with that on average male production wages. There are difficulties with this analysis. which are spelled out in the chapter.

For single people and couples (aged 35 years), replacement rates before housing costs were very low in Greece and in Texas and in Florida in the USA. They were also quite low in Pennsylvania, Germany, Canada (for single people), and the United Kingdom. Replacement rates were highest in Switzerland (Fribourg). Sweden, the Netherlands. Norway (Oslo) and Denmark. For couples with children the highest replacement rates were in the same countries (plus Australia). For most other countries the presence of children raises the replacement rate sharply. In general, replacement rates in the UK were around two-thirds of the way down the overall 'league table'.

Replacement rates for tone parents were generally lower than for couples with children if the lone parent did not have to pay for child care when working. The exceptions were Belgium. Portugal and Switzerland. If the working lone parent had to pay for child-care because of the presence of a child under the age of three. her replacement rate increased compared with a one-earner couple not requiring child care.

In general_replacement rates rise where there is additional help with housing costs for families on social assistance - substantially in some countries.

\section{A verage effective tax rates and the poverty-trap}

The other component of an economic analysis of work incentives is the substitution effect associated with the withdrawal of benefits. This is usually analysed as the 'effective marginal tax rate' (EMTR), estimated as the sum of the withdrawal rate on benefits, its interaction with any other form of benefit withdrawal. plus tax liabilities. EMTRs are usually estimated for a small change in labour supply at the margin.

In this chapter, average effective tax rates (AEMTRs) are calculated. estimated over the range of income between zero and average male earnings. This is a more realistic illustration of the choices available to individuals, who generally cannot vary their work effort by small increments. The measure provides an indication of any disincentive effects of moving from unemployment to full-time paid work.

Effective tax rates are lowest where benefit levels are lowest, since there is less assistance to be withdrawn. Correspondingly. effective tax rates are highest where benefits are relatively high, and exceed 100 per cent in those countries where replacement rates also exceeded 100 per cent. Effective tax rates are higher for those without children than for those with children, although in many cases they are lower for lone parents than for unemployed couples with children. In a number of countries. child care costs add to effective tax rates. Housing costs also increase effective tax rates in all countries apart from Portugal, Spain, and the USA. The UK. in this respect, performs relatively well. with rates below the average for most family types.

Social assistance schemes commonly impose a range of work-seeking requirements on recipients, and many offer incentives to return to work. Nevertheless many of the schemes involve high effective marginal tax rates which could, theoretically at least, act as a disincentive to labour force participation.

There is no clear association between the level of replacement rates or the stringency of work tests and the level of unemployment. If anything, there is a tendency for the countries paying higher social assistance benefits to have tougher work tests and lower levels of unemployment. 


\section{Chapter S. Diverse systems, common destination?}

Patterns of social assistance

The extent and generosity of schemes are not correlated. Extensive social assistance schemes in the English-speaking countries deliver relatively generous benefits in Australia and low benefits in the USA. There are similar variations among those countries with low or modest reliance on social assistance.

Looking at key features of social assistance schemes, including coverage and expenditure. level of benefits, administrative structure, operation of the means-test, work tests and degrees of officer discretion, it is possible to identify at least seven 'social assistance regimes':

- Seiectivc welfare systems: Australia and New Zealand

- $\quad$ The public assistance state: the USA

- Welfare states with integrated safety nets: the UK. Canada, Ireland and Germany

- Dual social assistance: France and the Benelux countries

- Rudimentary assistance: Southern Europe and Turkey

- Residual social assistance: the Nordic countries

- Highly decentralised assistance with local discretion Austria and Switzerland.

Japan is difficult to place in this typology, as it shares features of several of the categories.

Debates and policy initiatives

The English-speaking countries with extensive social assistance schemes report a range of issues in common, including the costs of assistance, work disincentives and fraud. In all these countries, except the USA, the high level of unemployment is also a continuing cause for concern.

Welfare dependency and the 'underclass' debate appears to be a defining feature mainly of the stigmatising public assistance system of the USA.

A variety of other concerns feature in debates in different countries, including the rights of immigrants and asylum seekers to social assistance benefits, payment for long-term care of the frail elderly (particularly in Germany and Austria), and the role of social workers in increasingly income maintenance-oriented assistance schemes (especially in the Scandinavian countries).

There is some debate also in the countries with localised schemes about whether to move towards more nationally-standardised regulations and benefit levels.

\section{Common pressures and national responses}

Pressures driving policy change in the area of social assistance can be seen as falling into two groups: first those deriving from forces external to the structure of benefit systems themselves, and secondly those resulting from internal features of policy systems.

New demands from external forces:

- demography

- changing family structures

- labour market change

- rising housing and fuel cost problems. 
Pressures from within policy systems:

A number of related pressures which impact on social assistance policy stem from within the structure of social security systems themselves. These include:

- the breakdown of traditional social insurance coverage

- $\quad$ pressures on public expenditure

- $\quad$ tensions between central and local governments over costs

- $\quad$ public sector staffing.

A key concern has been how to make welfare systems more compatible with changing labour markets. Policies can be grouped into 'carrots' and 'sticks'. 'Carrots' include reducing the withdrawal rate of benefits as earnings rise, providing education, training and work experience programmes for jobless claimants, and extending child care and other benefits to enable claimants with caring responsibilities to combine these with paid work. 'Sticks' include enhanced monitoring of able-bodied claimants, stricter tests of job-search activity, timelimited benefits and reductions in relative benefit levels.

Policy approaches vary across the major forms of assistance regime identified above. They can be grouped into four sets for this purpose:

- Countries with a past record of Cull or near-full employment (the Nordic countries, Switzerland, Austria and Japan): work incentives have been a relatively minor feature of debate (though this is changing in Denmark and Sweden).

- The limited social assistance regimes of southern Europe, includin $\mathrm{g}$ Turkey: here the debate on labour market disincentives within assistance itself is less relevant. Social assistance for the able-bodied of working age is vestigial and its impact on local labour markets likewise slight.

- The remaining Eli member states (excluding the UK and Ireland): here a growing concern with 'new poverty' and social exclusion in the 1980s has fuelled experiments with 'integration' programmes. These have all targeted young unemployed people and tied improved benefit levels to insertion in training and work experience schemes. In the Netherlands, there has been some tightening of work requirements for lone parents. Germany has not developed special insertion schemes, preferring to rely on its established training mechanisms.

- The extensive social assistance states of the English-speaking world (including bi-lingual Canada): it is in these countries that the relation between assistance and the labour market has assumed greater importance in policy debates. Ireland is an exception, with few major proposals or policy changes. New Zealand has opted for a variety of measures to make claiming less attractive, notably absolute reductions in benefit levels.

Other countries in this group have adopted a mixture of carrot and stick, including partial individualisation of income support for couples (Australia); a substantial extension of Earned Income Tax Credit in the USA; extra disregards within Family Credit and a package of back-towork provisions, plus reduction in the insurance element of unemployment payments_ under the new Jobseeker's Allowance (the UK). The sticks have also included more intensive requirements for job-search activity in all these countries. Following the mid-term elections in the USA. debate and policy proposals on welfare have become more punitive.

Overall, the pattern of response to common economic pressures is complex. The prominence of work incentives in policy debates is certainly greater in countries with greater reliance on social assistance. Yet even within this group, differences are noticeable between the Australian selective welfare state and the American public assistance state. 
The many differences observed in social assistance arrangements across the OECD raise questions about how schemes could be evaluated on a comparative basis. The report does not include a full-scale evaluation. as this was not within the study's remit or resources. Some possible criteria are, however. outlined and discussed. 


\section{Chapter 1 Introduction}

\subsection{Objectives}

This study is concerned with the ways in which developed societies provide a guarantee of minimum resources to citizens or residents who lack sufficient income from other sources. Such forms of protection are often described as constituting a 'safety net', through which people should not have to fall. By implication, if people without access to other sources of help fail to be caught by the safety net, they are likely to face poverty or some other manifestation of unmet need although, as the study shows. safety nets may themselves be set below some definitions of a poverty line. Not all OECD countries have such a general safety net but, where they do. a substantial part of the safety net is normally provided through cash benefits or services available to applicants only where they cannot provide for themselves that is. through some form of assessment of the resources already available to them.

Provision of this kind is commonly termed 'social assistance' and is the main focus of this study. though the term does not have a precise definition internationally. especially in translation. For example. in some countries, particularly those of the Nordic group, social assistance is a concept associated not only with income maintenance but also with social work service and individual treatment or rehabilitation; whereas in some others it is understood as referring mainly to discretionary supplementary schemes which are subsidiary to the main meanstested minimum income benefit. Taking branches of social security or benefits simply by their names may be misleading, which is one reason why Brown et al. (19911 have suggested abandoning the term social assistance altogether in comparative studies. We would argue, however. that the term 'social assistance' is sufficiently meaningful and commonly understood to justify its continued use, albeit with caveats. Nevertheless. problems of terminology indicate the need to look at the functions fulfilled by different elements of welfare structures rather than simply at the nominal systems. Therefore, although we frequently refer to social assistance, the main subject of enquiry is more accurately the range of benefits and services available to give a minimum (however defined) level of subsistence to people in need. based on a test of resources.

Even this definition is not without problems. First, we have stated that safety nets are mainly provided through social assistance. but there are countries where minimum income protection for some groups of people, particularly those over retirement age or disabled, comes through non-contributory 'citizens' benefits or pensions. awarded without a test of other resources. However. important as these benefits sometimes are, they are generally not discussed in detail in this study because the main focus of interest is on the resource-tested elements of the social safety net.

The second difficulty derives from the role of benefits which are tested against applicants' resources, but are designed to exclude higher earners rather than to offer a guaranteed minimum to the lowest income groups. There are examples of these in several countries, and they often derive from the selective refocusing of benefits such as family allowances which were previously universal. We deal with this problem by drawing a distinction between benefits we call 'poverty-tested' (that is, aimed at providing a minimum which is often regarded as a de facto poverty line) and those other income- or means-tested benefits which may have a 
different purpose, or may be withdrawn at a much higher income level. This distinction is elaborated in more detail in the next chapter. However, even with this approach absolute consistency cannot be achieved, because in some countries there are important benefits which are resource-tested and available in full when other income is very low, but which are withdrawn at a rate of less than 100 per cent as other income increases - often tapering out at a considerably higher level of income than would allow entitlement to the main social assistance benefit. The UK Family Credit is a good example. Such benefits are important because. to extend the circus analogy, they are intended to act less as safety nets than as trampolines or springboards to help lift beneficiaries back into independence through labour market participation.

The final problem of definition or terminology concerns the use of 'means-tested', income-tested" or 'income-related'. and 'asset-tested' to refer to different forms of resource testing. These terms are sometimes used in the literature loosely or interchangeably, but they do have different meanings, even if the processes which they are describing are not always clear cut. In this study income-tested or incomerelated benefits are generally taken to be those where the level of benefit to which an applicant is entitled is based only on an assessment of his or her earnings or other income (however defined) and where capital or other property and assets are not taken into account. Some benefits have specific rules relating to the value of property or other assets which applicants may have and still be entitled to benefit. and we describe these as assets tests. Where both income and assets are taken into account, benefits are described as means-tested. This definition of means testing also encompasses those benefits where there are no specific limits to the amount of capital or savings an applicant can have, but the savings are deemed to produce a notional amount of weekly or monthly income which is then counted in the income test.

The schemes which exist in each country have evolved out. of different traditions and often in symbiosis with other elements of the particular social security system: to that extent they are necessarily very different. However, there is evidence that all systems are facing common structural, social and economic pressures. Moreover the policy objectives, where these are articulated, may be said to be similar if not identical.

On the basis of the definitions outlined above, the aims of the study were to provide:

- a detailed country-by-country description of the structure of social assistance schemes in the member states of the OECD, together with data on trends in expenditure and claimant numbers; recent policy developments and proposals for change under consideration in the respective countries; and an assessment of the performance of different schemes, highlighting their strengths and limitations. This information is provided mainly in Volume Two.

- a comparative analysis of trend data; the legal and administrative structures of assistance schemes; policy debates and issues affecting the development of social assistance.

- detailed information on the comparative value of assistance available, with analysis of its components and implicit incentive structures.

The latter two aims are addressed primarily in this volume.

Within these core aims, the analysis of the different schemes has been structured by consideration of a number of specific issues. These include:

- conditions of entitlement: such as nationality/residence, age, availability for work, duration of entitlement

- coverage: inclusion and exclusion, treatment of different population groups 
benefit levels: how these are determined and methods of uprating

s means tests: which and whose resources are counted, earnings disregards

e administration and finance: local/national variations, adjudication, discretion, appeals, recovery of benefit, changes in circumstances

- fraud: methods of detection and control

- $\quad$ emergency and lump-sum payments

- benefits in kind and 'passported' benefits: exemption from health or other insurance contributions

- help with housing costs

- the relationship between means-tested and other benefits, and with health and social care

- the role of 'poverty lobbies' in debate and reform of social assistance.

\subsection{Research methods}

The research for this study was carried out using networks of national expert informants. The rationale was that informants based in the individual countries would have access to up-to-date information and recent research studies. and would be able to comment with authority on policy trends and debates in their countries. Because the study required both detailed descriptive material on the formal structure of social assistance schemes and commentary on their practical effectiveness, it was agreed to use two networks of informants - one consisting of senior officials in the relevant ministries and agencies, and the other of independent experts recruited from universities or research institutes.

The first group was asked to complete a pro forma questionnaire covering structural and legal details of their minimum income schemes, together with statements of official policy, statistical data on expenditure and claimant numbers, and summaries of recent or forthcoming changes. The independent experts were asked to provide a commentary, informed by research and debate in their countries, on key policy topics in social assistance. They also completed a 'model family income matrix' to allow comparison of the value of assistance benefits. both between countries and within countries in comparison with social insurance benefits and average earnings. The matrix was based on the package of benefits and charges likely to accrue to a set of 'typical' families in specified, identical circumstances in each country in May 1992. This approach built on a similar method developed for an earlier study of child support packages also carried out at the University of York (Bradshaw et al., 1993a). The model family methodology is discussed in detail in Chapter Six.

The independent experts also provided edited bibliographies and copies or summaries of key research studies. In some cases they helped to fill gaps in the information provided by officials. In July 1994 they attended a two-day colloquium held in York, to which policy makers were also invited, where the research team's initial analyses were modified or supplemented, items of the matrix methodology were clarified and policy issues were discussed in a comparative exchange of views and expertise. Finally, the information obtained from the two networks was put in context by reviewing national and comparative literature on social assistance, poverty and income distribution.

\section{Purchasing power parities}

One feature of the comparison of expenditure and the value of benefits across countries requires some comment. This is the use of 'purchasing power parities' (PPPs). Purchasing power parities are a method of comparing the actual value of a currency in terms of its purchasing power. PPPs convert national currency amounts into a common monetary denominator. which in this study has been expressed both in USS and £s sterling. PPPs are generally more satisfactory than exchange 
rates in that they take account of differences in the price of a common basket of goods and services in each country. and are less subject to the sharp fluctuations which can take place in exchange rates. The relationship between exchange rates and PPPs tends to vary between countries: for the majority of OECD countries PPPs are fairly close to the exchange rates, with the exception of the Nordic countries, Japan and Switzerland. where they are notably higher, and the southern European countries where they are notably lower. The PPPs used here have been developed by the OECD (Economic Outlook, 1993).

PPPs do have their limitations, however. It is arguable, for instance, that their primary utility is in application to $\mathrm{ag}^{\mathrm{g}}$ regate national data. rather than at a micro level, as applied to benefit rates or individual household income and expenditure. PPPs are calculated for each country on the basis of the consumption patterns of an average household. This study is about social assistance recipients_who may well have consumption patterns considerably different from the average. and if the degree of difference varies between countries then PPPs based on an average basket of goods may be misleading. In using PPPs for the comparison of disposable income after benefits and charges (in Chapter Six), it should also be acknowledged that there is an element of double counting involved in relation to housing, health and education. Variations in these costs are already taken into account in PPPs, and we are effectively counting them twice by adjusting net, post-housing cost. disposable incomes by PPPs. There are also difficulties in the construction of PPPs themselves and they are not always regarded as fully reliable. In spite of their limitations, it is nevertheless believed that they are the most useful way of comparing monetary values across the countries in this study, but they should be taken as indicators of relative benefit levels rather than exact measures. Table A6.2 appended to Chapter Six provides a comparison of PPPs and exchange rates in 1992 the year for which we have data from the model family matrix.

\section{A pproaches to comparative research}

In recent years there has been a proliferation of comparative research in the field of social policy, yet effective methodology for ensuring valid comparison is still relatively under-developed. Bradshaw (1994) has suggested that most comparative studies of social policy can be located within a matrix of two dichotomies -between 'macro' and 'micro' studies and between policy inputs' and 'outcomes'. Briefly, macro studies aim to explain the origins and evaluate the impact of particular formations of social policies at the aggregate level. Macro input studies are concerned with explaining welfare state effort_often focusing on levels of expenditure or tax structures over time and analysing the correlation with variables such as demography. economic development, party political control, the role of organised labour, religion, or the position of women (see, for example, VVilensky, 1975; Esping-Andersen, 1990; Heidenheimer et al., 1990). Macro outcome studies concentrate on the social and economic consequences of' welfare state activity on, for example, economic growth, unemployment, inflation, or social solidarity (for example, Cameron, 1985). The difference between inputs and outcomes here refers to the distinction between the policy instruments and what they achieve. Macro studies tend to serve an academic agenda rather than the more pragmatic concerns of' policy makers, although their significance in the latter field should not be overlooked.

Micro studies are generally concerned with drawing practical lessons for policy making by examining different systems (inputs) or their impact at the individual or household level (outcomes), though they may also contribute to theory in the course of doing so. Much government-commissioned research is likely to fall into this category. since policy makers and politicians are primarily interested in the immediate policy relevance of the findings. In the UK there has been a growing interest, on the part of government, in comparative research on social security inputs. partly stimulated by policy debates within the European Union. The questions typically asked about benefits are: what is available. to whom. for how long, how is it delivered, at what level and at what cost, and how successful are other countries at dealing with common problems? Micro studies of outcomes tend 
to rely on population surveys and generally involve secondary analysis of national datasets. Questions include the effectiveness of social policy in relieving poverty, fostering equality, or maintaining living standards for particular groups. Crossnational surveys are still fairly rare (with the Eurobarometer attitude studies being amon $^{\mathrm{g}}$ the few exceptions). though the EU is launching a Union-wide household and income survey in 1995. Following pioneering work by Beckerman (1979) and Rainwater et al. (1986). the Luxembour ${ }^{\mathrm{g}}$ Income Study (LIS)' has become one of the main vehicles for comparative research in this field. Many of the initial problems of comparison have been overcome and a stream of high quality research has resulted (see. for example, O'Higgins and Jenkins, 1989; Mitchell, 1991; Smeeding et al._ 1992; Whiteford and Kennedy. 1995).

Hauser (1993) has proposed another way of classifying basic approaches to comparative analysis. In this typology the first approach is 'system-by-system'. where analysis concentrates on institutional features of the social security system or a sub-system of it. The second approach is 'group-by-group' and starts from the positions in different societies of specific population groups, such as lone parents or older people. The third approach is more abstract and deals with comparisons on a 'problem-by'-problem' basis. looking, for example. at poverty, incentives, or redistribution. The raft of comparative poverty studies emanating from the Luxembourg Income Study represents perhaps the most common application of this approach. The final 'state-by-state' type is more comprehensive, comparing whole welfare states in their contemporary or historical forms, and is perhaps exemplified by Esping-Andersen's (1990) work on welfare state typologies.

In practice much research is a mixture of these types. and there are aspects of all of them in this study. Mainly we take the system-by-system approach. In Bradshaw's typology the study can be seen primarily as a micro study of inputs.

In spite of the advances made in comparative research. there remain considerable methodological problems in the collection and interpretation of data in ways that provide genuine comparison of like with like. Comparative analysis relies on there being a sufficient level of basic similarity between countries for some generalisation from empirical evidence. But the more heterogeneous a ${ }^{\mathrm{g}}$ roup of countries, the greater becomes the possible number of unique, specific features. It can be argued that the European Union, and to a lesser extent the OECD, are by definition groupings of states which share. at least in a broad sense, core similarities. Nevertheless, the cultural and economic differences and historical specificities are still great enough to present considerable limitations to comparative analysis.

Even if the general level of comparability is regarded as acceptable, there remains a choice as to the numbers of countries to be studied. Here the researcher is presented with the risk of either 'going naive' - that is, of losing richness and extensiveness of analysis in favour of larger numbers of comparator countries -- or of 'going native' and pursing more sensitive qualitative analysis, but not achieving more general explanation. For this study the choice was made to cover a large number of countries, because basic comparable information on social assistance in many of the OECD countries was lacking. It should be recognised, however, that there are some questions which it has not been possible to pursue in great detail, and that there are differences between countries in the level and quality of information available.

A further problem derives from the complexity of welfare states. Packages of provision are made up in quite different ways in different countries, involving interactions between earnings, social insurance, taxation, public services and private provision which are difficult to grasp even in one country. They are also

The LIS protect has assembled a database of more than 45 microdata sets on income and expenditure from participating countries (17 in the 1985 wave of surveys). The database is held at the Centre for Populations, Poverty and Policy Studies (CEPS/INSTEAD) at Walferdange, Luxembourg. Datasets are transformed from the original microdata using a standard format to allow comparative analysis. 
constantly evolving and changing, making information quickly out of date. Comparative analysis has to be based on the selection of characteristics which are considered relevant in all the different countries. Yet there may not be a general consensus on what features are important -- a particular difficulty in a study of social assistance_ where its salience within social security as a whole varies considerably between countries. Since this project was commissioned initially by the UK Department of Social Security. there is naturally an interest in how other countries deal with issues and problems encountered in the UK system. It is recognised. however, that there are other perspectives and these are highlighted where appropriate.

\subsection{Why study social assistance?}

Before moving on to describe the structure of the report, it is worth asking why it might be considered important to study social assistance schemes and what the policy context is for such research. In answering these questions we review very briefly the development of social welfare systems. the growing interest in forms of social protection based on selectivity and the previous research carried out in this area.

Public welfare in most of the countries in the study be ${ }^{g}$ an with forms of local poor relief which represent the antecedents of contemporary social assistance schemes. In the course of the first half of the 20th century, Poor Law provision in most countries was overlaid, if not entirely superseded, by systems of social insurance and, later, categorical non-contributory benefits, which served purposes wider than simply the relief of poverty. Social assistance schemes themselves were substantially revised and codified in many countries in the decades following World War $\mathrm{H}$, although some have retained more of their poor relief features than others.

There are many different ways of looking at the developments in social welfare systems in the 20th century. The most basic view might be that two main traditions have emer ${ }^{\mathrm{g}}$ ed - those countries with systems of social protection based primarily on contributory social insurance and those relying mainly on other arrangements. Alternatively the traditions could be seen as those where means-tested assistance schemes were increasingly seen as residual elements of social protection, as in most of the countries of continental Europe, and those where targeting through incomeand means-testing became an increasingly important strategy. Examples of the latter tradition would be the antipodean countries and, to a lesser extent, the UK and the USA.

Both these approaches are over-simplistic, however. since the welfare mix which different countries have adopted is more complex than that suggested by a single dichotomy. A number of more comprehensive typologies have been developed to classify and explain the nature of welfare states, among which one of the most influential has been that of Esping-Andersen (1990). He classified countries into three 'welfare regimes', based on indicators of social stratification and on scores of what he calls 'decommodification'. This refers to the extent to which entitlement to benefits (particularly pensions, sickness and unemployment benefit) frees workers from dependence on competition in the market place. Thus those countries with flat-rate, universal benefits based on minimum qualifying periods score more highly than those relying on contributory and earnings-related benefits. His three regime types were Conservative/Corporatist, among which he includes Austria, France. Germany and Italy-; Liberal, including Australia. Canada and the USA; and SocialDemocratic, incorporating the Scandinavian countries.

There have been many criticisms of Esping-Andersen's typology. Lewis (1992), for example, has argued that the concept of decommodification is over-identified with the position of male workers and gives insufficient attention to the contribution women make to the enhancement of welfare through unpaid work. Bradshaw et al.'s (1993a) study of child support suggested a rather different grouping of regime types if family benefits were taken into account. Castles and Mitchell (1991) have 
also suggested that Australia is wrongly allocated to the liberal grouping on the basis of its means-tested system, without recognition of the outcomes deriving from it. and have proposed a fourth regime type based on countries with a labourite tradition. In general. Esping-Andersen's model is relatively insensitive to variations between countries with extensive social assistance schemes, and later chapters of this report attempt to map these differences onto his typology of welfare regimes.

Most countries have seen periodical re-enactment of debates about the basis on which social protection should be financed and delivered. However, since the oil shocks and the so-called 'crisis of welfare' which ensued from the international economic problems of the 1970s (O'Connor. 1973; Gough, 1979), these arguments have increasingly centred on an opposition between 'universal' and 'targeted' benefits. To some extent it can be argued that this is a false dichotomy. As Atkinson (1993). among others. has pointed out, it is difficult to give any examples of true 'universal' benefits anywhere in the world. Genuine universalism requires some form of basic or citizenship income. In practice virtually all existing benefits involve some degree of conditionality or are targeted in some way, either towards certain categories of people, such as those with children in the case of child benefit, by contingency in the case of disability benefits. or on the basis of contribution records for social insurance benefits. Means-testing is but one form of selectivity.

Arguments for selectivity on the basis of resources do appear to have been gaining

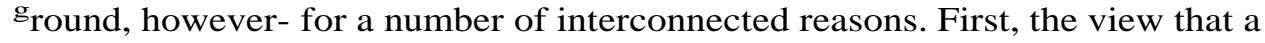
level of social security expenditure which requires relatively high taxation and employer costs can damage economic effort, particularly in the context of global competition, has become increasingly dominant in international political and economic discourse. This is a view which has been forcefully expressed by the UK government in negotiations with its EU partners on the social dimension of the Union. It is also a common thread which runs through the OECD's analyses of member countries' recent economic performance. as well as through the Jobs Study, which examined unemployment and proposed strategies for coping with labour market change (OECD, 1994a). While the European Commission and many of the EU governments have resisted any wholesale reduction of insurance-based social protection, and indeed have recently emphasised the importance of the social dimension (Commission of the European Communities. 1994a). the White Paper on Growth, Competitiveness and Employment (Commission of the European Communities, 1994b)_nevertheless recommends a range of measures aimed at increasing employment, which include reductions or restructuring of employers' non-wage costs and boosting of work incentives through income-related supplements to earnings.

A further, parallel stimulus to interest in social assistance has been the identification of a growth in what has been called 'new poverty' in the European and other developed countries (Room- 1990). This poverty is thought of as new in two senses: first there has been a 'rediscovery' in a number of countries that genuine problems of poverty exist in spite of overall increasing affluence; and secondly there have been changes over time in the composition of the poorest groups. There is some debate as to how new much of this poverty actually is and even more on how it should be measured on a comparative basis. Various researchers (for example, Deleeck et aL. 1992: Gustaffson and Lindblom, 1993; Bardone and Degryse. 1994; Hagenaars at al., 1994; R.amprakash, 1994), have carried out or evaluated a range of different statistical approaches - all broadly based on measures of percentages of households with incomes or expenditures below proportions of the average - and have found that the results are highly sensitive to both the percentage line drawn and the equivalence scale used. It is often pointed out that such measures are not in themselves indicators of poverty as such but of relative inequality (Veit-Wilson, 1994a). It is also necessary to remember that when looking at countries such as those in this study we are talking of poverty in rich countries (Townsend. 1992), so that. for example, the official USA poverty line is more than six times the average per capita income of India (Atkinson. 1993). In many ways the debate about relative versus absolute poverty 
has become somewhat sterile. It is now a truism to say that poverty is relative, but as Saunders (1994, p.21) has argued,

To accept that poverty is relative is not to equate poverty and inequality. but rather to acknowledge that needs - the only basis for a poverty standard - are defined and determined in a social context.

This is where social assistance schemes are particularly important, because they become de facto poverty lines, based on what governments decide are minimum income levels below which no one should be expected to fall. How far these lines are based on needs is another question. As the study shows. and as Veit Wilson (1994b) has also demonstrated, it is unusual to find a contemporary 'minimum income standard' which is clearly based on a scientific or consensual measure of what different households need.

Nevertheless, in spite of the caution necessary when discussing poverty and inequality in OECD countries, one pervasive feature of the many different studies is that they tend to show broadly similar groups falling into the lowest parts of the income distribution in most countries. Thus we find that households headed by lone parents, by unemployed people, by women, by older people, large households. those without any member in employment or headed by a person with a low level of education, households in certain regions and, in some countries, those working in farming and agriculture, are all more at risk of relative poverty, as measured in the studies, than other groups.

On the other hand. poverty is not necessarily greater in countries where the groups who are particularly vulnerable make up larger proportions of the population (Hagenaars et al., 1994). This is partly because levels of inequality are affected by the general levels of social protection available in different countries and by the extent to which social security measures are directed at particular risk groups. Nevertheless, one of the characteristics of contemporary poverty in Europe is that it increasingly stems from the limitations of existing social security arrangements particularly those based on status maintenance through insurance principles - in dealing with changes in demography, family forms and behaviour, and the labour market. Thus many of those facing poverty do so through the lack of a continuous contributory record, either. in the case of youth unemployment, because there has been no opportunity to build up a record, or through exhaustion of entitlement because of long-term unemployment. or through interruptions in labour market participation because of caring responsibilities or family breakdown. Although the prevalence of poverty is not entirely correlated with low levels of spending on social protection in different countries, it does appear to be relatively high where systems of minimum income protection are less fully developed (Bardone and Degryse, 1994). If social assistance is generally becoming more salient, as we show in the next chapter, this is particularly because of increases in long-term unemployment, in lone parenthood, in low pay and in primary earnings inequalities.

In this context the extent to which there are safety nets and the role such schemes play in relation to other parts of the social security system, both in poverty prevention or relief and in social reintegration, become important questions. The arguments for greater 'targeting' are well known. In particular, benefits targeted on those most in need are thought to be more effective and efficient at closing poverty gaps than universal payments, which may go in part to people who do not need them. In times of economic stringency, when excessive public spending is widely seen as detrimental to competitiveness and high taxation as a disincentive to individual effort, the idea that poverty can be more effectively alleviated by reallocating existing transfers is attractive. On an international level, targeting is seen as the most effective tool. as suggested by the World Bank's 1990 World Development Report, which stated that: 
... a comprehensive approach to poverty reduction calls for a program of well-targeted transfers and safety nets as an essential complement to the basic strategy. (World Bank, 1990, p.3 -- quoted in Atkinson. 1993)

In line with this strategy, economic aid from the international financial institutions. including the World Bank and the International Monetary Fund. to the transitional economies of Eastern Europe has also increasingly been weighted towards the establishment of means-tested safety nets to back up their limited insurance-based systems. Within the European union, one response to research findings suggesting high levels of poverty amongst its citizens has been to adopt a Draft Recommendation (Cor (91) 161), urging member countries to institute guarantees of minimum resources conforming to a set of broad common principles and to supply reports on progress achieved. Basic outlines of such provisions are now included in the annual social security tables produced by the Commission's Management Information System on Social Security (MISSOC) project.

Yet in spite of this growing interest in benefit selectivity, there are also a number of well-known drawbacks of the targeted approach. It is not necessary to elaborate them here (see. for example Deacon and Bradshaw, 1983; Saunders. 1991: Atkinson, 1992, Gough. 1994), but they include potential problems of intrusive enquiry, stigma, social divisiveness. low take-up, poverty traps and high administrative costs. There is also a danger in concentrating on poverty relief to the exclusion of other possible legitimate objectives for social security: these might include protection against risk; horizontal equity, redistribution over the lifecycle, and the promotion of social cohesion (Commission on Social Justice, 1994). Finally, it is commonly argued that focusing benefits on the poor may undermine the wider support for social security which is necessary in order to finance targeted schemes which are generous enough to be effective (Saunders, 1991). Overall, there is a general problem of whether targets themselves are adequately defined and whether policy instruments are designed in such a way as to be able to hit them (Whiteford, 1994a). However. the arguments for and against targeting are often presented at a level of principle which assumes that all forms of means testing are alike. In fact, as we have already stated, there are important distinctions. As mentioned earlier, some Australian social policy analysts in particular have argued. from the perspective of their almost totally means-tested or income-related social security system, that generalised critiques of targeting need to be tested more closely against the outcomes of differing policy arrangements (Mitchell, 1991; Mitchell et al,. 1994).

From a policy maker's perspective, it is important to understand both how far reliance on targeted or means-tested benefits in the developed welfare states actually has increased over the last decade, whether there are any distinctive patterns or differences emerging in the way safety net benefits are designed and delivered, and the extent to which particular approaches to common policy problems have been successful or ineffective. Given the increase in many countries of long-term unemployment. a key theme here concerns both the work incentive or disincentive effects implicit in the structure of assistance schemes and the effectiveness of programmes of 'insertion' or integration into the labour market. The role of assistance schemes in relation to the wider social security systems and the labour market also cannot be fully understood without some assessment of the relative value of benefit payments to different household types in the countries studied.

Although there is a growing number of comparative studies of social security provision, to our knowledge no one has previously carried out a systematic study of social assistance schemes on the scale of the study reported here. Euvrard (1989) has surveyed the key principles of the main minimum income schemes in the European Community for a conference on basic income in Europe, while Liebfried (1991) included a broad overview of the range of assistance schemes in a wider study of convergence in social welfare in Europe. As part of the strategy adopted 
with the Draft Recommendation mentioned above, the European Commission in 1992 sponsored a working party of national experts who have produced reports from the member countries on their systems for guaranteeing minimum resources, to which we have had access. As was mentioned above. the MISSOC project has also begun to include basic descriptive tables on minimum income schemes for the EU countries, but at present they only provide an outline of provision and cannot give any indication of the spread or impact of social assistance.

A number of important studies have been mounted of groups of related countries, in particular Scandinavia, such as that by Fridberg (1993). Overbye (1994) has also looked at the ways different European countries have combined insurance and assistance schemes, such that the distinction can be blurred but in ways that vary between countries for different risk groups, Stjerno (1994) has compared assistance schemes in the Nordic countries with a number of other European countries to see how their institutional features conform to the common idea of the 'Nordic model'.

One study, by Lodemel and Schulte (1992), has compared the broad principles and features of social assistance schemes in a selected number of EU countries to see how they impact on welfare state typologies such as that of Esping-Andersen. They highlighted four main features which. they argued, differentiated social assistance regimes from one another:

- the existence of generalised minimum income schemes as opposed to those only for specific categories of people

- an emphasis on income maintenance rather than on social integration and treatment

- the balance between legal rights to benefits and discretionary access

S central versus local (or regional) responsibility for legislation, administration and finance.

On this basis Lodemel (1992) posited four regime types, as follows:

1. Nordic: including all the Scandinavian countries, with decentralised and largely discretionary systems aimed at 'marginal' groups and emphasising social work treatment.

2. Latin: including the southern European and Mediterranean countries, as well as France, with less developed general assistance schemes and an emphasis on 'insertion".

3. Continental: including Austria. Belgium, Germany. Luxembourg and the Netherlands, with common roots in Bismarckian social insurance, general rights-based assistance alongside categorical schemes, emphasis on subsidiarity but a lesser degree of decentralisation than in the Nordic countries.

4. British: the UK model is seen as a distinct tradition, deriving from limited social insurance provision which led to more extensive assistance. This became nationally organised, with a complex set of rights and entitlements, and is based almost entirely on income maintenance with little social work involvement.

We discuss in later chapters how far Lodemel's typology is supported by the more detailed evidence available from this study.

Another approach taken by Mitchell et al. (1994) i Australia has been to use Luxembourg Income Study micro-data for a number of countries to look at the outcomes, in terms of benefit generosity and poverty alleviation, generated by different policy mixes of universal and targeted benefits. Their argument challenges what they see as a Eurocentric, and in particular a Nordocentric, obsession with the instruments of provision rather than the actual outcomes, and they conclude 
that by these criteria the means-tested Australian system performs relatively well compared to other countries with different policy mixes.

The present study cannot produce a systematic assessment of outcomes. Nor can it present an exhaustive evaluation of the different schemes (though Chapter Eight suggests a series of criteria against which such an evaluation might be carried out). The report does aim. however, to present a more comprehensive mapping of social assistance schemes in the developed world than has previously been attempted.

\subsection{The structure of the report}

The report continues in Chapter Two with a discussion of conceptual problems in classifying social assistance schemes. This chapter then examines the trends in expenditure on social assistance and the numbers and types of people receiving benefits. Chapter Three compares the principles and key features of assistance schemes, concentrating on conditions of eligibility and entitlement, approaches to means-testing. and forms of support for housing costs and exceptional needs. Chapter Four then looks at issues of administration and delivery of benefits, including the central/local dimension. This is followed by a discussion of current debates on poverty and approaches to minimum income support, taking in the role and influence of 'poverty lobbies" in the different countries, and examining the way in which benefit rates for assistance schemes have been determined. Chapter Six then analyses the structure and value of income packages derived mainly from social assistance and compares these both across and within countries, in relation to insurance benefits and average wages. The next chapter looks at the incentive or disincentive effects, primarily in relation to work. inherent in the various benefit structures. Chapter Eight concludes the report with an analysis of how systems are evolving and changing in the face of common pressures and a discussion of how the evidence of the study might contribute to a better understanding of welfare regimes.

The information and data drawn on in the following chapters is, unless otherwise referenced, based primarily on that supplied to the researchers by official respondents in the respective countries through the proforma questionnaire, or in the form of statistical and other reports provided separately. Some gaps in this information were filled by the academic respondents. drawing on published statistical reports or other research data. Fuller descriptions of the individual countries" assistance schemes, and more detailed referencing of sources, can be found in Volume Two of this study. 


\section{Chapter 2 Social Assistance Across the OECD: Patterns and Trends}

Chapter One included an attempt to define social assistance for the purposes of the study, and briefly outlined the ways in which different forms of provision have been categorised. This chapter begins by proposing a more explicit comparative taxonomy of social assistance schemes so as to impose some order on the great variety of national programmes which the study has covered. Without such a taxonomy it is impossible to discern patterns and trends in the salience of social assistance in different countries. The second part of the chapter presents data on national variations in expenditure on social assistance in 1992 and on trends since 1980. Lastly, we turn to the recipients of social assistance and analyse such data as are available on their numbers and composition, again presenting a static picture of the situation in 1992 and a dynamic one of changes since 1980.

\subsection{A taxonomy of social assistance}

As was stated in the previous chapter. the term 'social assistance' does not have a fixed or universal meaning. In some countries social assistance extends to embrace a wide range of non- resource-tested but categorically-targeted social aid for such groups as orphans, immigrants and older people. In others (but also frequently the same countries) it excludes means-tested or income-related benefits which are administered as part of social insurance. The first task, therefore, is to identify that set of social programmes which constitute the main focus of investigation.

There are three, and only three, basic mechanisms by which the state can directly allocate income or services to individuals or households (see for example Atkinson, 1989). The first mechanism is the 'universal' or contingency benefit allocated to all citizens within a certain social category. These benefits are not related to income or employment status. Secondly, there is social insurance. where the benefit is related to (a) employment status and (b) contributions paid in to the scheme. Both of these conditions can be interpreted more or less stringently. The third comprises meanstested or income-related benefits where eligibility is dependent upon the current or recent resources of the beneficiary. though other categorical conditions may also apply. This study focuses principally on the third category of resource-tested benefits.

Resource-tested benefits are sometimes referred to as 'targeted' benefits. although this is not always a particularly helpful term. All existing benefits and services are targeted in some way on people in certain defined circumstances (Miller and Tomaskovic-Devey, 1990; Saunders, 1991). Moreover. both contingency and social insurance programmes can be directed at low-income groups or at those in other categories of acute need. Contingency benefits and services can be aimed at groups highly correlated with extreme need, such as homeless children or long-term unemployed people. Social insurance programmes can build in minimum pensions and other benefits to provide an income floor below which no members of the scheme should fall. The present study addresses these schemes only in so far as they involve resource testing.

Within resource-tested programmes Gough (1994) makes three preliminary distinctions:

\footnotetext{
2 - Directly' restricts this to the provision of cash or non-cash benefits by state agencies. Other indirect methods include tax allowances and mandated private benefits or services. 'Individuals and households' means that services targeted on specific spatial locations arc excluded, though geography may enter into the definition of the contingency which the benefit or service is designed to meet.
} 
1. The first is between 'poverty testin ${ }^{g_{1}}$ and 'general means or income testing'. The former is concerned to provide resources to people who would otherwise fall below a certain, usually officially-defined, minimum standard of living. This minimum standard will often reflect a political judgement rather than a scientific assessment (Veit-Wilson, 1994a). It may or may not he referred to as a poverty standard. but there is some recognition of providing a floor or 'safety net' below which nobody should fall. General means-testing, on the other hand, is concerned to relate benefits to current resources across a broader range of income groups -- it may be no more than a means to restrict access by the well-off (cf. Eurostat, 1993, p.6).

2. There is also a distinction between cash and 'tied' benefits. The former provide money benefits. These may be emergency relief payments to cope with disasters or exceptional needs, or more regular payments. "Tied" benefits entitle the recipient to free or subsidised use of a specific service. or to a refund of rebate for all or part of the charge for a specific service ${ }^{3}$. A particularly important tied benefit in many countries is housing assistance.

3. Referring back to the definition of contingencies, there is in practice an important distinction between schemes for all people within a certain income/resources group and those awarded to more specific categories within this group. such as older or disabled persons.

These three distinctions generate eight combinations, as shown in Figure 2.1.

\begin{tabular}{l|l|c|c|}
\multicolumn{2}{|c|}{ Figure _. I: A taxonomy of means-tested schemes } \\
\hline \multirow{2}{*}{ Poverty-tested } & Cash & 1 & $\begin{array}{c}\text { Specific } \\
\text { groups }\end{array}$ \\
\hline & Tied & 3 & 2 \\
\hline \multirow{2}{*}{ General means-tested } & Cash & 5 & 4 \\
\cline { 2 - 4 } & Tied & & 6 \\
\hline
\end{tabular}

Our concern to study only those schemes for people whose resources are officially held to be insufficient would suggest that we ignore all general income-related benefits in cells 5--8, such as the growing number of income-tested family allowances. However, this causes problems in Australia and New Zealand which have no social insurance features. Their social security systems are, in the terms introduced above, wholly means-tested or income-related, but they are not focused solely on those with minimum incomes. To limit our study to 'poverty-tested' programmes would be to exclude all antipodean social benefits except for the residual Special Benefits. Since these two countries have played an important role in the evolution of social assistance they could not sensibly be excluded. Moreover, whether or not the benefits extend to those with higher incomes, the purpose of such schemes is still to provide a minimum level of subsistence (however defined) to those at the bottom. As such they must be included in the study.

Nevertheless, extending the scope of social assistance in this way raises problems elsewhere. To be consistent we then have to include Family Credit in Britain. income-related family allowances in Italy and Belgium, the Earned Income Tax Credit in the USA. Arbeitslosenhilce in Germany, housing allowances in Sweden, and so on.

Similarly, to exclude all tied benefits or benefits in kind from the study would be to hinder comparison with countries where these are important, as is the case, for example, with Food Stamps in the USA. Moreover, the extent to which housing allowances are integrated with social assistance varies considerably across

Since a tied benefit, such as a housing allowance. can be paid in cash, this term is less misleading than referring to 'in-kind' or 'non-cash benefits. 
countries, so to exclude them would distort comparisons. The difficulties involved in taking account of housing costs in international comparisons are discussed in Chapter Six.

It was therefore decided to obtain information on all forms of resource-tested benefits, but to categorise them in the following way.

1. General assistance: provides cash benefits for all or almost all people below a specified minimum income standard (cell I above): for example, the UK Income Support or the Belgian Minimex.

'. Categorical assistance: provides cash benefits for specific groups (cells $2+6$ above). Examples include unemployment assistance in Germany and the Netherlands, social pensions in Italy, or almost all Australian and New Zealand benefits.

3. Tied assistance: provides access to specific goods or services in kind or in cash (cells $3+4+7+8$ ). Because of the importance of housing assistance, and because its relationship with cash assistance varies across countries, tied assistance is further divided as follows:

3a. Housing assistance

3b. Other tied assistance.

It should be noted that our definition of categorical assistance includes, in some countries, schemes which are not always regarded as assistance within the countries themselves. Thus, where unemployment assistance, or supplementary pensions for older or disabled people, involve an income test which restricts payments to those with low incomes, these are included in our definition, even though these benefits may also have a contributory element. This applies particularly to Austria, Germany and Switzerland. There is also an argument for taking note of the fairly substantial expenditure in Canada on income-tested supplements to the federal pension schemes, even though they are not generally seen as 'last resort' assistance payments. We therefore include Guaranteed Income Supplement and Spouse's Allowance as categorical payments in the following tables. Insurance benefit topups with no general test of income are excluded, however.

In this chapter social assistance refers to all three categories together.

Table 2.1 allocates all the major resource-tested programmes in the OECD countries to one of these categories. The table applies mainly to the situation in 1992. unless otherwise specified. This is to allow for the comparison of expenditure, on which data is not available for many countries after this date. Where major changes to the structure of benefits, such as the introduction of a new housing benefit scheme, have taken place since 1992, these are noted. It should also be noted that general assistance schemes often cover some or all of housing costs, either through higher basic payments or through a supplementary element based on the costs of housing. Some countries have separate and discrete housing benefit schemes, as shown in column 3 (and some have both). The ways that countries offer help with housing costs are discussed in more detail in the next chapter. The table excludes separate schemes for one-off payments, which are also dealt with in Chapter Three. Finally, the table includes some schemes which, according to the taxonomy above, extend benefits to people with incomes above the poverty or minimum income line.

\footnotetext{
${ }^{a}$ Housin $^{\mathrm{g}}$ allowances are the subject of a separate comparative study for the UK Department of Social Security by .Kemp, involving a smaller number of OECD countries.
} 
Table 2.1: A taxonomy of national resource-tested assistance programmes (1992)

\begin{tabular}{|c|c|c|c|c|}
\hline Country & General assistance & Categorical assistance & Housing assistance' & Other tied assistance \\
\hline Australia & Special Benefit & $\begin{array}{l}\text { Age Pension; Service Pension; } \\
\text { Disability Support Pension; } \\
\text { Wife Pension; Carer Pension; } \\
\text { Sole Parent Pension; Sickness Allowance; } \\
\text { Unemployment Allowances; Family } \\
\text { Payments }\end{array}$ & $\begin{array}{l}\text { Rent assistance and rent rebates (but } \\
\text { expenditure included in overall social } \\
\text { assistance figures) }\end{array}$ & \\
\hline Austria & $\begin{array}{l}\text { So iialhilfe, for people in } \\
\text { private households }\end{array}$ & $\begin{array}{l}\text { Supplementary Pensions; } \\
\text { Unemployment Assistance }\end{array}$ & & $\begin{array}{l}\text { Means-tested So:ialhilfe for } \\
\text { persons in institutions }\end{array}$ \\
\hline Belgium & Alin:Men- & $\begin{array}{l}\text { Perm( Garanli pour Per,sonnes Agess; } \\
\text { Allocation pour Handicapper; } \\
\text { Allocation .Ptmliluale Garantie }\end{array}$ & & \\
\hline Canada & $\begin{array}{l}\text { Canada Assistance Plan } \\
\text { (as framework for provincial } \\
\text { programmes) }\end{array}$ & $\begin{array}{l}\text { Guaranteed Income Supplement } \\
\text { Spouse's Allowance }\end{array}$ & $\begin{array}{l}\text { Canada Mortgage and 1-lousing } \\
\text { Corporation programmes }\end{array}$ & \\
\hline Denmark & Social Bistand & & Housing Benefit (from I-. 4) & \\
\hline Finland & Living Allowance & & Housing Allowance & \\
\hline France & $\begin{array}{l}\text { Rerenu Minimum d'Insertion } \\
\text { (RMI) }\end{array}$ & $\begin{array}{l}\text { Minimum Vieillesse; Allocation our } \\
\text { Adu/tes } 11 \text { ondicapes (AAII); Allocation } \\
\text { de .Poront I.sotll (API); Minimwn } \\
\text { Itavalidite; Allocation Veuvage; Allocation } \\
\text { de Solidarite Spectfique; Allocation } \\
\text { d7nscrlion }\end{array}$ & $\begin{array}{l}\left.\text { Allocation Ingenu'nt Farnilrale (AI, } I^{i}\right) \text {; } \\
\text { Aide Pe'rsonnali.scie au Logeinent (4 P1..); } \\
\text { Allocation Lngcnte;rrt ,Soeiaic (ALS) }\end{array}$ & \\
\hline Germany & Soialhilfe; subsistence aid & 4rbeitslasenhi.fle & II itlnageld & $\begin{array}{l}\text { Sn ialhilfe: aid in special } \\
\text { circumstances }\end{array}$ \\
\hline Greece & & $\begin{array}{l}\text { Scheme Err Unprotected Children; Scheme } \\
\text { for the Protection of Maternity; Scheme } \\
\text { for Non-insured Elderly }\end{array}$ & Housing benefit for non-insured elderly & \\
\hline Iceland & Financial Assistance & $\begin{array}{l}\text { Income and Household Supplements to } \\
\text { Basic Pensions }\end{array}$ & Housing Allowance & \\
\hline Ireland & $\begin{array}{l}\text { Supplementary Welfare } \\
\text { Allowance }\end{array}$ & $\begin{array}{l}\text { Unemployment Assistance; } \\
\text { Pre-retirement Allowance; Old Age, } \\
\text { Widow's and Orphan's Non-Contributory } \\
\text { Pensions: Deserted and Prisoner's Wife } \\
\text { Allowance; Carer's Allowance; Lone } \\
\text { Parent Allowance; Disabled and Blind } \\
\text { Person's Maintenance Allowance, Family } \\
\text { Income Supplement }\end{array}$ & & \\
\hline
\end{tabular}




\begin{tabular}{|c|c|c|c|c|}
\hline Country & General assistance & Categorical assistance & I lousing assistance' & Other tied assistance \\
\hline Italy & $\begin{array}{l}\text { Local cash assistance } \\
\text { (If in } \text { I }^{1} \text { mo I"dole) }\end{array}$ & $\begin{array}{l}\text { Pensioxe Son/ate; Pensione di Inohilita; } \\
\text { Veteran Is Pension; A ssegno al Nrscleo } \\
\text { Enailicrre } \\
\text { inns }\end{array}$ & & Local assistance services \\
\hline Japan & $\begin{array}{l}\text { Livelihood slid (plus } \\
\text { Education Aid, Housing Aid. } \\
\text { Medical Aid, Maternity Aid, } \\
\text { Occupational Aid, and } \\
\text { Funeral Aid) }\end{array}$ & & & \\
\hline $\begin{array}{l}\text { Luxembourg } \\
\text { sins }\end{array}$ & $\begin{array}{l}\text { Revenue Minimum Gwarti; } \\
\text { AVC }\end{array}$ & $\begin{array}{l}\text { \{llocrrtiura pour Personnes Crravemcnt } \\
\text { Handieappes; Allocation de Soios }\end{array}$ & Allocation de Chrarrffag >e & \\
\hline Netherlands & Algetnene Bijstond (ABW) & $\begin{array}{l}\text { Regulation for Unemployed Employees } \\
\text { (RWW); Income Provisions for Older and } \\
\text { Partially Disabled Workers (IOAW), } \\
\text { Income Provisions for Formerly Self- } \\
\text { Employed (IOAZ). Supplementary Benefit } \\
\text { (TW) }\end{array}$ & Housing Benefit & \\
\hline New Zealand & Special Benefit & $\begin{array}{l}\text { Unemployment Benefit; Training Benefit; } \\
\text { Sickness Benefit; Invalidity Benefit; } \\
\text { Widows Benefit; Domestic Purposes } \\
\text { Benefit: Transitional Retirement Benef } \\
\text { New Zealand Superannuation; Family } \\
\text { Support }\end{array}$ & Accommodation Supplement (from 1994) & \\
\hline Norway & Social Economic Assistance & Transitional Allowance & $\begin{array}{l}\text { State Housebu.nk [lousing Benefit; } \\
\text { Pensioners' 1-lousing Benefit }\end{array}$ & \\
\hline Portugal & & $\begin{array}{l}\text { Family Allowance; Supplementary } \\
\text { Allowance; Nursing Allowance: Orphan's } \\
\text { Pension; Social Invalidity Pension; Social } \\
\text { Old Age Pension; Young People's } \\
\text { Integration Benefit: Survivors Grant }\end{array}$ & Housing Benefit & \\
\hline Spain & Ingreso Minim() de.Inserolon & $\begin{array}{l}\text { Means-tested Aged pension; Means-tested } \\
\text { Di:_bility Pension; Unemployment } \\
\text { A-;si, } \text { ___i }_{\text {i }} \text { ne }\end{array}$ & & \\
\hline Sweden & Social Assistance & & $\begin{array}{l}\text { KBT-Municipal .housing allowance for } \\
\text { pensioners; SK.BT-Statelmunicipal } \\
\text { housing benefit }\end{array}$ & \\
\hline Switzerland & $\begin{array}{l}\text { Aide ,Soeiale/So:tale } \\
\text { Pursorge }\end{array}$ & $\begin{array}{l}\text { Supplementary retirement and invalidity } \\
\text { pensions }\end{array}$ & & \\
\hline Turkey & $\begin{array}{l}\text { Social Assistant: and } \\
\text { Solidarity Scheme }\end{array}$ & Old Age and Disability Assistance & & $\begin{array}{l}\text { Green card medical } \\
\text { assistance } \\
\text { sins }\end{array}$ \\
\hline
\end{tabular}




\begin{tabular}{|c|c|c|c|c|}
\hline Country & General assistance & Categorical assistance & Housing assistance $^{2}$ & Other tied assistance \\
\hline UK & Income Support & $\begin{array}{l}\text { Family Credit: Disability Working } \\
\text { Allowance }\end{array}$ & Housing Benefit & $\begin{array}{l}\text { Community Charge Benefit } \\
\text { (later replaced by Council } \\
\text { Tax Benefit); Free school } \\
\text { meals }\end{array}$ \\
\hline USA & $\begin{array}{l}\text { Food Stamps; General } \\
\text { Assistance }\end{array}$ & $\begin{array}{l}\text { Aid to Families with Dependent Children; } \\
\text { Supplemental Security Income; Veterans' } \\
\text { Pension; Earned Income 'fax Credit }\end{array}$ & $\begin{array}{l}\text { Federal Housing Assistance; Low Income } \\
\text { Home Energy Assistance }\end{array}$ & $\begin{array}{l}\text { Medicaid; School Lunch and } \\
\text { Breakfast programme; } \\
\text { Special Supplementary Food } \\
\text { Programme; Job Training } \\
\text { Partnership Act; Head Start }\end{array}$ \\
\hline
\end{tabular}

Notes

Unless otherwise indicated

i.e. separate housing assistance programme, excluding those integrated into other assistance schemes 
Only Portugal and Greece lack any sort of general, non-categorical assistance programme. and that of Italy is limited. This. however. says nothing about the coverage, let alone the benefit levels, of general assistance schemes in the remaining countries. Most also have one or more categorical assistance schemes. but these are particularly salient in Australia and New Zealand, the USA. Belgium. France. Ireland. Italy. Luxembourg, Netherlands. Portugal and Spain. In particular, older and disabled people are separately catered for in different programmes. This is the case in France (also for lone parents and widows), Belgium. Portugal. Italy and Spain: and in Austria. Iceland and Switzerland, if the income-tested pension supplements are included.

Japan is somewhat difficult to place. It has several different types of aid, for people with different types of need: yet the different forms of benefit are highly integrated and assessment takes place under the same rules. It seems most appropriate to regard them as part of one, ${ }^{\mathrm{g}}$ eneral assistance scheme. but it should be recognised that treating them as such affects the way expenditure figures are viewed in the tables below.

In Austria. Germany, Ireland and the Netherlands there are separate assistance schemes for unemployed people. The USA is unique in the range and size of other tied assistance programmes. The majority of all these programmes are targeted at low-income households, families or individuals, but in several countries there are now income-tested programmes, of which family allowances are most common, which extend their benefits further up the income scale through extensive earnings disregards or tapered benefit withdrawal rates. Australia and New Zealand are unique in the extent of such schemes.

\subsection{Expenditure on social assistance}

Comparable data on social assistance expenditure are highly problematic. In a few countries. accurate national expenditure figures are not available at all, while in others the definition of what constitutes social assistance expenditure varies substantially. Data are not necessarily available broken down consistently by the analytical categories adopted for the study and even where they are, figures are not always available for each category of benefit. This inevitably makes the exercise of identifying trends and patterns akin to a jigsaw puzzle where many pieces are missing and some belong to a different box. The following section, therefore, represents only a first attempt at making sense of the overall picture. Estimates are based on a number of unavoidable. but less than ideal, assumptions and have to be read along with the numerous caveats and explanations provided as footnotes to the tables. The tables provide a basis on which we and others can improve in the future.

Table 2.2 gives an estimate of total public expenditure on all social assistance in 1990 as a proportion of three figures: Gross Domestic Product (GDP), 'social protection' and 'social security' all as calculated by the OECD. 'Social protection' includes all public social spending in cash and in kind, excluding education. but including health: 'social security' measures all government social security and welfare transfers to households. It should be noted that the databases from which the two latter measures are drawn are collected separately, from different sources, and 'social security' in this context cannot simply be read as a subset of 'social protection'. They do, nevertheless, provide the best sources of reasonably consistent comparative data, although figures are missing for some countries. It should also be noted that the OECD estimates of social security spending. on which Table 2.2 and subsequent tables are based. differ considerably in some cases from estimates provided by individual governments for this study. The latter are used substantially in the individual country chapters of Volume Two, and sometimes result in estimates of the proportions of spending devoted to social assistance which differ from those in this volume. 
Table 2.2 shows the considerable variation in the importance of social assistance in different countries. Total assistance expenditure varied as a share of GDP from 0.2 per cent to 12.5 per cent; as a share of social protection expenditure between less than two per cent and 65 per cent: and as a share of social security expenditure between two per cent in Switzerland and 100 per cent in New Zealand. These were much wider variations than for spending on other social programmes, such as social insurance. However, the higher proportions of expenditure derived particularly from Australia and New Zealand: without these outliers. the range of variation narrows considerably.

A minority of countries spent substantially above the average on all means- and income-tested benefits. Whether we take more than two per cent of GDP, more than ten per cent of the social protection budget, or more than 30 per cent of social security as measures, the same five countries emerge on top: Australia, Ireland. New Zealand, the UK and the USA. The Netherlands also spent more than two per cent of GDP. and Iceland might be in this group if spending on its pension supplements were included. Those countries apart, the social security systems of the English-speaking' world clearly rely more on means-testing than elsewhere. This group of countries is similar to those with low 'decommodification' scores, according to Esping-Andersen (1990. p.52). ${ }^{6}$ Medium spenders on social assistance include France, Germany and Italy, plus Canada, Denmark, Sweden. Austria and the Netherlands. Those with small spending levels on social assistance (less than one per cent of GDP) are a mixed group. They include Japan (although national estimates of social assistance expenditure as a proportion of social security spending put it in the 'medium' group); the other European countries except Austria and Sweden; the southern European countries excluding Italy; and Turkey.

We include Canada in this group, while acknowledging that it is also French-speaking

${ }^{-}$This grouping maps less well on to his cluster of countries scoring highly on 'liberalism': Japan and Switzerland were present in Esping-Andersen's list but are absent from ours. Indeed, they were the two countries with the lowest expenditure on social assistance. 
Table 2.2: Total social assistance expenditure in 199091' as a percentage of GDP, social protecoo and social security

\begin{tabular}{|c|c|c|c|}
\hline Country & $\%$ GDP & $\%$ Social Protection & $\%$ Social Security \\
\hline Atlistralia $=$ & 5.2 & 40.6 & $89.2^{\prime \circ}$ \\
\hline Austria & 1.4 & 4.6 & 6.0 \\
\hline Belgium` & 0.6 & 2.5 & 2.9 \\
\hline Canada' & 2.0 & 10.7 & 18.6 \\
\hline Denmark & 1.2 & 4.4 & 7.0 \\
\hline Finland & 0.2 & 0.8 & 2.0 \\
\hline France & 1.8 & 6.8 & 9.7 \\
\hline Germany & $\mathrm{I}-8$ & 7.6 & 11.8 \\
\hline Greece & $0-1$ & 0.6 & 0.9 \\
\hline Iceland' & 0.2 & Ilia & 1.4 \\
\hline Ireland & 4.3 & 21.6 & 39.9 \\
\hline Italy & 1.4 & 5.6 & 8.8 \\
\hline Japan & 0.3 & 2.5 & 4.1 \\
\hline Luxembourg & 0.4 & 1.4 & nrta \\
\hline Netherlands & 2.3 & 8.0 & 11.8 \\
\hline New Zealand & 12.5 & 65.4 & 100.0 \\
\hline Norway & 0.8 & 2.8 & 4.8 \\
\hline Portugal' & 0.5 & 3.0 & 4.6 \\
\hline Spain' & 1.1 & 5.5 & 8.1 \\
\hline Sweden & 1.0 & 3.1 & 6.7 \\
\hline Switzerland' & 0.8 & $\mathrm{n} / \mathrm{a}$ & 7.1 \\
\hline Turkey' & 0.5 & n'a & $\mathrm{nra}$ \\
\hline UK & 3.0 & i 3.4 & 30,9 \\
\hline USA & 2.7 & I8.9 & 32.8 \\
\hline Unweighted average & 1.9 & & \\
\hline
\end{tabular}

Sources: Numerators: Data supplied by national officials and academic respondents.

Denominators: Social Protection (includes health spending): OECD (1994b), Social Security; OECD Household Transfer Database (OECD. 1994d), unless otherwise stated

Notes:

For some countries figures are for calendar rather than financial years

National, not OECD, estimates of social security

Includes expenditure on federal Guaranteed Income Supplement for older people, plus Spouse's Allowance (totalling 0.7 per cent of GDP)

1988. Excludes expenditure on maternity scheme and frst-time job seeker's allowance, for which figures were not available

Does not include expenditure on income-tested pension supplement, for which data were unavailable Japan is one of the countries where expenditure estimates provided by the national government differed most from those based on the OECD data. Japanese Ministry estimates give social assistance expenditure in 1990 as 9.5 per cent of total social security policy

1992

Includes expenditure on income-tested age and invalidity minimum pension supplements. Data are for 1992

1993

Although virtually all benefits in Australia are resource-tested. this figure is less than $100 \%$ because the Household Transfer Database definition includes other Commonwealth and State transfers which are not counted nationally as part of social security expenditure.

To keep matters simple. the succeeding tables normally use GDP as the denominator, but the differences in country rankings brought about by using social spending measures should not be overlooked. Expressing expenditure on resourcetested benefits as a proportion of total social spending reveals its relative weight and helps to identify different welfare regimes.

Table 23 divides total estimated spending as a share of GDP (this time for 1992) into the four cate ${ }^{\mathrm{g}}$ ories of programme distinguished in Table 2.1. The table uses the term 'cash assistance' to denote the total of expenditure on general and categorical schemes. though it should be noted that both types of scheme in some countries can involve the provision of services as well as cash. Looking first at general, non-categorical assistance programmes, the UK stands out - spending 2.5 per cent of G.DP on Income Support in 1992 - followed by Canada and Denmark. When categorical schemes are considered, the distinctive patterns of New Zealand and Australia. but also of Ireland. are clearly revealed. Putting the two together we find the English-speaking countries in the lead in spending, with the notable 
exception of the USA. In most continental EU member countries, categorical assistance for specific groups is more important than general programmes.

Britain leads the world in spending on specific means-tested Housing Benefit (which goes to people other than just those with incomes at the assistance level), followed by two very different countries: France and Sweden. When cash and housing assistance are aggregated. the country patterns identified in Table 2.2 begin to emerge. The English-speaking nations, minus the USA and Canada, spent the most on social assistance. The relatively low spenders comprise several distinct groups of countries: Austria and Switzerland (even when insurance pension supplements are included): Japan; low-income Turkey and Portugal; two Nordic countries - Norway and Finland, and two other EU members Luxembourg and Belgium.

Other tied. means-tested benefits are prominent in three countries. On the one hand there is the USA, notably as a result of its unique medical assistance programme Medicaid. On the other hand, Germany and Austria spent the bulk of assistance monies on residents of homes for older people and in payment for other care services. This may be a feature of social assistance expenditure in other countries which is not always apparent from official statistics.

Table 2.3: $\quad$ Social assistance expenditure as a percentage of Gross Domestic Product (GDP). 1992

\begin{tabular}{|c|c|c|c|c|c|c|c|}
\hline Country & $\begin{array}{c}\text { General } \\
\text { assistance } \\
\mathrm{I}^{1} 1\end{array}$ & $\begin{array}{c}\text { Categorical } \\
\text { assistance } \\
121\end{array}$ & $\begin{array}{c}\text { Cash } \\
\text { assistance } \\
\left.\right|^{1+2} \mid\end{array}$ & $\begin{array}{c}\text { Housing } \\
\text { assistance } \\
131\end{array}$ & $\begin{array}{c}\text { Cash+ } \\
\text { housing } \\
\text { assistance } \\
11+2+3]\end{array}$ & $\begin{array}{c}\text { Other tied } \\
\text { assistance } \\
\text { (4] }\end{array}$ & $\begin{array}{c}\text { Total } \\
\text { social } \\
\text { assistance } \\
11+2+3+41\end{array}$ \\
\hline Australia & 0.1 & 6.7 & 6.8 & & 6.8 & & 6.8 \\
\hline Austria & 0.1 & 0.7 & 0.8 & n.'a & 0.8 & 0.4 & 1.2 \\
\hline Belgium & 0.1 & 0.6 & 0.7 & & 0.7 & & 0.7 \\
\hline Canada & 1.8 & 0.7 & 2.5 & n'a & 2.5 & & 2.5 \\
\hline Denmark & 1.4 & $\mathrm{n}-\mathrm{a}$ & 1.4 & $\mathrm{n} / \mathrm{a}$ & 1.4 & & 1.4 \\
\hline Finland & 0,4 & - & 0.4 & $\mathrm{n} / \mathrm{a}$ & 0.4 & - & 0.4 \\
\hline France & 0.2 & & 1.2 & 0.8 & 2.0 & - & 2.0 \\
\hline Germany & 0.5 & 0.3 & 0.8 & 0.2 & 1.1 & 0.9 & 2.0 \\
\hline Greece' & - & 0.1 & 0.1 & nia & 0.1 & & 0.1 \\
\hline Iceland & 0.1 & $0.1=$ & 0.2 & $\mathrm{n} / \mathrm{a}$ & 0.2 & & 0.2 \\
\hline Ireland & 0.3 & 4.8 & 5.1 & & 5.1 & - & 5.1 \\
\hline Italy & 0.2 & 2.7 & 2.9 & & 2.9 & 0.4 & 3.3 \\
\hline :japan & 0.2 & 0.1 & 0.3 & & 0.3 & & 0.3 \\
\hline Luxembour $^{\mathrm{g}}$ & 0.4 & 0.1 & 0.5 & $\mathrm{n} / \mathrm{a}$ & 0.5 & & 0.5 \\
\hline Netherlands & 0.8 & 1.4 & 2,2 & $\mathrm{Ma}$ & 2.2 &. & 2.2 \\
\hline New Zealand & 0.1 & 13.0 & 13.0 & & 13.0 & & 13.0 \\
\hline Norway & 0.5 & 0.2 & O.? & 0.2 & 0.9 & & 0.9 \\
\hline Portugal & nia & $\mathrm{n} / \mathrm{a}$ & 0.4 & nia & 0.4 & & 0.4 \\
\hline Spain & 0.03 & $1.0^{\prime}$ & 1.1 & - & 1.1 & & 1.1 \\
\hline Sweden & 0.5 & - & 0.5 & 1.0 & 1.5 & & 1.5 \\
\hline Switzerland & 0.2 & 0.6 & 0.8 & & 0.8 & - & 0.8 \\
\hline Turkey' & 0.5 & $n=a$ & 0.5 & - & 0.5 & n'a & 0.5 \\
\hline UK & 2.5 & 0.1 & 2.6 & 1.2 & 3.9 & 0.3 & 4.1 \\
\hline USA & 0.4 & 0.9 & 1.3 & 0.3 & 1,6 & 2.1 & 3.7 \\
\hline
\end{tabular}

Notes: Expenditures refer to programmes shown in Table 2.1 unless otherwise stated.

Numbers may not add up due to rounding.

indicates that there are no substantial forms of expenditure within the particular category, whereas $\mathrm{n} / \mathrm{a}$ indicates that information is not available.

1988

1993

Estimate of expenditure on income-related pension supplements, based on Table 11.1 in volume Two

Excluding means-tested age pension (for which expenditure figures not available)

Sources: Numerators: Data supplied by national official or academic respondents 
The variety of ways in which social assistance is organised complicates comparisons, especially over time. Table 2.4 shows trends in estimated spending on 'cash' social assistance that is. column 3 of Table 2.3 - as a share of GDP between 1980 and 1992. However. for the three countries with significant housing assistance programmes - France. UK and Sweden - it also gives figures including these programmes.

Four countries exhibited an increase in social assistance spending over this period of more than one percentage point of GDP: Australia, New Zealand, Ireland and the UK (over two percentage points when housing assistance is included). Japan is the only country for which we have reliable data which apparently registered a declining share - Switzerland did so for group assistance schemes only.

When we turn to proportionate rather than absolute increases. the picture changes. It is the Nordic countries which have witnessed the most rapid growth of social assistance spending, albeit from a low base. They are followed by the UK and France (both exacerbated by fast-growing housing assistance), Germany, Ireland, New Zealand and Belgium. The result is some slight narrowing of the gap in national expenditure on cash resource-tested benefits. As a footnote to the table indicates, the figures on categorical expenditure in France are likely to be a substantial underestimate, though the percentage change is probably more accurate.

Another perspective on changes since 1980 is given in Table 2.5, which shows total means- and income-tested expenditures (the last column in Table 2.3) as a share of total social security expenditure. It reveals a rising share of the social security budget spent on assistance-type benefits in every country (for which we have data) except Canada, Japan and Switzerland. The decline in spending for Canada, however, is only as a result of a decrease in Spouse Allowance payments (which, as we have seen, are not generally regarded as part of social assistance). Canada Assistance Plan spending increased over the period by 2.4 per cent. The fastest growth is still in some of the Nordic countries (excepting Sweden where high but constant housing allowances swamp the rise in cash assistance). Otherwise the proportionate increase is remarkably similar across all the OECD countries. All types of welfare regime exhibited a rising share of expenditure on means-tested schemes in the 1980s - a notable convergence of otherwise disparate national patterns. 
Table 2.4: Cash social assistance as a proportion of GDP. $1980-92$

\begin{tabular}{|c|c|c|c|c|c|c|c|}
\hline Country' & 1980 & 1985 & 1990 & 1991 & 1992 & $\begin{array}{c}\text { Change } \\
\text { 1980492' } \\
(\% \text { GDP) }\end{array}$ & $\begin{array}{c}\text { Index: } \\
199211980 ' \\
1980=1110\end{array}$ \\
\hline Australia' & $5.4^{6}$ & 6.0 & 5.2 & 6.1 & 6.8 & 1.4 & 126 \\
\hline Austria' & 1.0 & 1.0 & 1.4 & 1.2 & 1.3 & 0.3 & 124 \\
\hline Belgium & 0.4 & 0.6 & 0.6 & 0.7 & 0.7 & 0.2 & 156 \\
\hline Canada & 1.6 & 2.0 & 2.0 & 2.3 & 2.5 & 0.9 & 156 \\
\hline Denmark & n'a & 0.9 & 1.2 & 1.4 & 1.4 & ma & ttia \\
\hline Finland & $0.1^{\prime}$ & 0.1 & 0.2 & 0.3 & 0.4 & 0.3 & 438 \\
\hline France $^{4}$ & 0.2 & 0.3 & 0.5 & 0.5 & 0.5 & 0.2 & 196 \\
\hline :.:incl housing & 0.4 & 1.0 & 1.2 & 1.3 & 1.3 & 0.7 & 205 \\
\hline Germany' & 1.0 & 1.6 & 1.6 & 1.6 & 1.6 & 0.6 & 160 \\
\hline Greece & $0.1^{\prime}$ & 0.1 & 0.1 & na & na & 0.0 & 100 \\
\hline Iceland & nia & n.a & 0.2 & 0.2 & 0.2 & $\mathrm{n} / \mathrm{a}$ & $\mathrm{n} / \mathrm{a}$ \\
\hline Ireland & 3.0 & 4.5 & 4.3 & 4.7 & 5.1 & 2.2 & 174 \\
\hline Italy & I. 1 & 1.3 & 1.4 & 1.5 & 1.5 & 0.4 & 135 \\
\hline Japan & 0.4 & 0.4 & 0.3 & 0.3 & 0.3 & -0.1 & 60 \\
\hline Luxembourg & n.'a & $\mathrm{n} / \mathrm{a}$ & nla & 0.4 & 0.4 & $\mathrm{n} ! \mathrm{a}$ & nia \\
\hline Netherlands & 1.7 & 2.5 & 2,3 & 2.2 & 2.2 & 0.5 & 133 \\
\hline New Zealand' & 8.6 & 9.2 & 12.5 & 13.5 & 13.0 & 4.4 & 151 \\
\hline Norway & 0.1 & 0.3 & 0.7 & 0.7 & 0.7 & 0.5 & 486 \\
\hline Portugal & 0.2 & 0.6 & 0.5 & 0.4 & 0.4 & 0.2 & 221 \\
\hline Spain & 0.3 & 0.8 & IA & 1.1 & 1.2 & 1.0 & 473 \\
\hline Sweden & 0.2 & 0.4 & 0.4 & 0.4 & 0.5 & 0.3 & 272 \\
\hline ::: ins l housing & 0.8 & 1.2 & 1.0 & 1.3 & 1.5 & 0.7 & 186 \\
\hline Switzerland & n1a & n'a & na & $\mathrm{n} / \mathrm{a}$ & 0.8 & $\mathrm{rt} \% \mathrm{a}$ & $\mathrm{n} / \mathrm{a}$ \\
\hline Turkey & $\mathrm{r} \sim / \mathrm{a}$ & $\mathrm{n} / \mathrm{a}$ & $\mathrm{n} \mathrm{a}$ & rua & $0.5^{\prime}$ & $\mathrm{n} / \mathrm{a}$ & $\mathrm{n} ; \mathrm{a}$ \\
\hline UK & 1.4 & 2.1 & 1.7 & 2.1 & 2.6 & 1.2 & 190 \\
\hline incl housing & 1.8 & 3.0 & 2.6 & 3.2 & 3.9 & 2.1 & 212 \\
\hline$U S A$ & 1.1 & 1.0 & 1.0 & 1.2 & 1.3 & 0.2 & 115 \\
\hline
\end{tabular}

Notes: See footnotes to Table 2.3.

Increase to 1991 or 1990 where no data for 1992

Social assistance data for financial years (117 to 30116) related to later calendar year; eg 1991192 as proportion of 1991

Includes means-tested cash payments to residents in non-private households (such as residential care homes)

Includes Revenu Minimum d'Iscsertion, Allocation de Parent /sole and Allocation $a^{g} c y, d u^{p}$ es Handicapes only

Social assistance data for financial years. These ran from 14 313 until 1990, then from 117-3016. Social assistance data related to earlier year until 1990 (eg 1988189 as proportion of 1988) and to later year after 1990 (eg 1991/92 as proportion of 1992)

1982

1981

1993

Sources: Data supplied by national official and academic informants 
Table 2.5: Total social assistance expenditure as a proportion of social security. 1980-1992

\begin{tabular}{|c|c|c|c|c|c|c|c|}
\hline Country & 1980 & 1985 & 1990 & 1991 & 1992 & $\begin{array}{c}\text { Change } \\
\text { 1980-92' } \\
\text { ( \%n social } \\
\text { security) }\end{array}$ & $\begin{array}{c}\text { Index: } \\
\text { 199211980' } \\
1980=100\end{array}$ \\
\hline Australia & $67.6^{2}$ & 81.2 & 89.2 & 90.1 & 90.3 & 22.7 & 134 \\
\hline Austria & 5.7 & 5.2 & 7.2 & 6.6 & 6.7 & 1.0 & 117 \\
\hline Belgium & 2.3 & 2.2 & 2.9 & 3.1 & 3.0 & 0.7 & 129 \\
\hline Canada & 19.6 & 19.9 & 18.6 & 1.8 .5 & 18.9 & -0.7 & 96 \\
\hline Denmark & $\mathrm{n} / \mathrm{a}$ & 6.1 & 7.0 & 7.6 & ${ }^{7} .8$ & n'a & $\mathrm{n} \mathrm{a}$ \\
\hline Finland & $0.9^{2}$ & 1.3 & 2.0 & 2.1 & rya & 1.2 & 240 \\
\hline France' & 3.5 & 5.2 & 6.5 & 6.5 & 6.4 & 2.9 & 184 \\
\hline Germany & 7,1 & 11.0 & 11.9 & $\mathrm{Ma}$ & $\mathrm{n} / \mathrm{a}$ & 4.7 & 167 \\
\hline Greece & 1.3 & 1.2 & 0.9 & $\mathrm{n} ? \mathrm{a}$ & $\mathrm{Ma}$ & $M a$ & nia \\
\hline Iceland & nia & $M a$ & 1.4 & 13 & 1.2 & $\mathrm{n} \mathrm{a}$ & $\mathrm{n} \mathrm{a}$ \\
\hline Ireland & 30.9 & 34.7 & 39,9 & 41.2 & Hitt & 10.3 & 133 \\
\hline Italy & 9.1 & 8.7 & 8.8 & 9.6 & 9.1 & 0 & 100 \\
\hline Japan & 7.3 & 5.5 & 4.1 & 3.8 & 3.7 & 3.5 & 51 \\
\hline Luxembourg & $\mathrm{n} \% \mathrm{a}$ & 1.1 & nia & $\mathrm{n} / \mathrm{a}$ & 1.4 & Ma & nia \\
\hline Netherlands & 8.3 & 12.4 & 11.8 & 11.2 & .10 .9 & 2.6 & 131 \\
\hline New Zealand & 82.8 & 85.5 & 1.00 .0 & 100.0 & 100.0 & $30.3^{\prime}$ & 137 \\
\hline Norway' & 2.5 & 3.7 & 4.8 & 4.8 & 4.8 & 2.3 & 191 \\
\hline Portugal & 2.3 & 6.1 & 4.7 & 4.1 & 3.8 & 1.5 & 167 \\
\hline Spain & $2.1^{2}$ & 6.0 & 8.1 & 7.9 & 8.4 & 6.3 & 403 \\
\hline Sweden & 4.6 & $6.7^{6}$ & 5.4 & 6.3 & 6.7 & 2.1 & 146 \\
\hline Switzerland & $\mathrm{Ma}$ & $\mathrm{a}:$ & $\mathrm{Ma}$ & $\mathrm{n}$ a & 1.8 & $\mathrm{a} / \mathrm{a}$ & $\mathrm{n} ? \mathrm{a}$ \\
\hline Turkey & $\mathrm{Ma}$ & $\mathrm{n}<\mathrm{t}$ & n-'a & $\mathrm{n}: \mathrm{t}$ & $\mathrm{Ma}$ & nett & na \\
\hline UK & 21.9 & 30.2 & 30.9 & 30.8 & 33.0 & 11.1 & 151 \\
\hline USA & 29.3 & 32.7 & 32.8 & 36.5 & 39.8 & 10.5 & 136 \\
\hline
\end{tabular}

Notes: See footnotes to Table 2.3.

Increase to 1991 or 1990 where no data for 1992

1982

As in Table 2.4, the figures for categorical assistance in France are based on a low estimate of assistance spending

4 General assistance only

Because of the way the figures in the OECD Household Transfer Database are derived, and because of changes in the tax benefit year, percentages for New Zealand in 1990 and 1992 were greater than 100. The change figures represent the actual estimate of change since 1980 1986

Sources: Numerators: Official national informants

Denominators: OECD Household Transfer Data Base, except for Australia (1990 onwards). Belgium (1985 onwards), Iceland, Luxembourg, Portugal (1990 onwards), UK (1992) - where Government calculations of social security used. These different denominators can affect the shares shown; for example, the shares for Germany are considerably higher than those in German Government sources

\subsection{Recipients of social assistance}

We turn now to estimates of the numbers of people receiving social assistance, which are beset by problems similar to those which apply to expenditure data. Table 2.6 gives an estimate of the total number of beneficiaries of the various schemes identified in Table 2.1 in 1992, expressed as a share of the total population in each country. This provides a broad indication of the salience of social assistance in the different countries. Unless otherwise stated, all the tables in this section refer not to the number of recipient families or households, but to the total numbers of beneficiaries in these families or households.

One of the first difficulties is that a household, or its members, may receive more than one benefit. Column 3 of Table 2.6 adds together the beneficiaries of general and group assistance schemes where it is known that they are mutually exclusive. Where they are not, the higher of the two numbers is inserted to indicate the minimum potential numbers receiving assistance benefits at that time. This is why for some countries the figure in column 3 is not the sum of those in the first two columns. The same issue arises for recipients of housing assistance and other tied assistance. Here the table gives the proportions receiving each benefit, though 
again we are justified in taking the highest figure in columns 3.4 and 5 to indicate the relative scale of means- and income-tested programmes in the population.

It should he noted that none of these tables take any account of the level of benefits provided: whether a family is receiving 50 pounds or 50 pence a week, its members will show up as beneficiaries. Similarly. a benefit unit will be counted whether it receives payments for one week in a year or continuously throughout the year. Discussion of benefit levels and duration of spells of claiming is held over to later chapters.

Column I of Table 2.6, giving the numbers of individual beneficiaries of general assistance schemes, shows the scale of Income Support in the UK. It delivered benefits to 15 per cent of the British population. a higher proportion than covered by any other single programme in the OECD area. The US Food Stamps programme, provincial schemes in Canada, and in recent years the Finnish Living Allowance, all delivered to about ten per cent of their populations, whilst assistance in Sweden and Germany covered more than five per cent.

Table 2.6: Individuals (including children) in $\mathrm{f}$ al flies receiving social assistance in 1992, as a percentage of total national populations

\begin{tabular}{|c|c|c|c|c|c|}
\hline Country & $\begin{array}{c}\text { General } \\
\text { assistance } \\
111\end{array}$ & $\begin{array}{c}\text { Categorical } \\
\text { assistance } \\
121\end{array}$ & $\begin{array}{c}\text { Cash } \\
\text { assistance } \\
13=1+21 \text { (net } \\
\text { nos) }\end{array}$ & $\begin{array}{c}\text { Housing } \\
\text { assistance } \\
141\end{array}$ & $\begin{array}{c}\text { tither tied } \\
\text { assistance } \\
151\end{array}$ \\
\hline Australia & 0.2 & 17.6 & 17.8 & & \\
\hline Austria & 0.7 & 4.1 & 4.8 & & \\
\hline Belgium & 0.5 & 8.1 & 3.6 & & \\
\hline Canada & 9.9 & 5.1 & 15.0 & & \\
\hline Denmark & 8.3 & & 8.3 & & \\
\hline Finland & 9.2 & & $9 .^{2}$ & & \\
\hline France & 1.1 & 1.2 & 2.3 & 8.8 & \\
\hline Germany & 4.5 & 0.7 & 5.2 & $2.8^{`}$ & 2.3 \\
\hline Greece & & 0.7 & 0.7 & - & \\
\hline Iceland' & 2.9 & 6.8 & 9.7 & & \\
\hline Ireland & 0.5 & 11.9 & 12.4 & & \\
\hline Italy $=$ & & 4.6 & 4.6 & & \\
\hline Japan & 0.7 & & 0.7 & & \\
\hline Luxembourg & 2.7 & 0.6 & 2.7 & 0.03 & \\
\hline Netherlands' & 1.5 & 2.2 & 3.7 & 6.3 & \\
\hline New Zealand & & 25.0 & 25.0 & & \\
\hline Norway & $4.0^{2}$ & 1.0 & 4,0 & 1.9 & \\
\hline Portugal' & -- & 2.1 & 2.1 & & \\
\hline Spain & 0.3 & 2.7 & $2 . ?$ & $\mathrm{ma}$ & \\
\hline Sweden & 6.8 & & 6.8 & & \\
\hline Switzerland & 1,8 & 2.3 & 2.3 & & \\
\hline Turkey & na & $\mathrm{Ma}$ & na & $\mathrm{n} \% \mathrm{a}$ & \\
\hline UK & 15.3 & 0.6 & 15.9 & 7.6 & 11.6 \\
\hline USA & 10.0 & $7.5^{5}$ & 10.0 & 2.2 & 11.2 \\
\hline
\end{tabular}

Notes: Beneficiaries of programmes shown in Table 2.1 unless otherwise stated_

Cash assistance numbers $=\mathrm{col} \mathrm{I}+\mathrm{col} 2$ minus estimated numbers receiving financial Assistance who are 65 years and older 1991

Social Economic Assistance `cases`. As some people may claim in more than one municipality during one year. the number of recipients is somewhat lower (around six per cent lower in 1992).

Recipients 'of all non-contributory benefits. Hence this figure is a considerable over-estimate of the numbers receivin ${ }^{\mathrm{g}}$ means-tested benefits 1990

r Supplemental Security Income and Aid to families with Dependent Children only Medicaid only

Sources: National official and academic informants

When categorical schemes are included, New Zealand and Australia predominated - a quarter of New Zealanders and one in six Australians received resource-tested benefits. Ireland also joins Britain among the high-coverage countries, along with Canada if recipients of Guaranteed Income Supplement and Spouse's Allowance 
are included. Aid to Families with Dependent Children and Supplemental Security Income covered 7.5 per cent of the US population, but these mainly overlapped with Food Stamps (though not entirely, which under-estimates the total number in the USA). In the next group, with the USA. were Finland. Iceland (if its pension supplements are included). Sweden and Austria (mainly on the basis of Unemployment Assistance and pension supplements). At the other extreme, only two per cent of the population. or less, received cash social assistance in France, Greece, Japan, Portugal, and Switzerland.

France, the UK and the Netherlands are exceptional in the coverage of their housing assistance schemes. In Britain, the beneficiaries overlap with those of Income Support to a great extent, but in France they far outnumber the recipients of R.MI. or the other assistance schemes, substantially raising the profile of meanstesting in France. Evidence on other tied benefits is sketchy, but two countries stand out: the USA with over I I per cent receiving Medicaid. the most extensive assistance programme in the country. and the UK with a similar share receiving Community Charge Benefit in 1992. When housing assistance and Sonialhife for people in special circumstances arc included. Germany too joins the ranks of those countries with extensive proportions of their populations receiving resource-tested benefits.

The overall conclusion seems clear - in 1992 the English-speaking countries operated the most extensive social assistance programmes. Of the remaining nations, the following stand out: Iceland (only on the basis of its pension supplements). Finland, France. Germany. the Netherlands and Sweden. Those with the lowest numbers receiving assistance included Japan; Austria and Switzerland; and Portugal and Greece.

Table 2.7 reports trends in beneficiaries of cash assistance (column 3 of Table 2.6) as a proportion of total populations since 1980 . The absolute changes range from the UK at one extreme (a growth in share of population of nearly seven percentage points) to New Zealand at the other (a decline of over five points). The latter is in contrast to the expansion of New Zealand expenditure on social assistance, and implies a more focused targeting of benefits. 
Table 2.7: Individual beneficiaries of cash assistance. as a percentage of national populations.. 1980-1992

\begin{tabular}{|c|c|c|c|c|c|c|c|}
\hline \multirow[t]{2}{*}{ Country } & \multirow[t]{2}{*}{1980} & \multirow[t]{2}{*}{1985} & \multirow[t]{2}{*}{1990} & \multirow[t]{2}{*}{1991} & \multirow[t]{2}{*}{1992} & \multicolumn{2}{|c|}{ Change Index: 19921} \\
\hline & & & & & & $\begin{array}{l}1980-92 \\
\text { (\% pop) }\end{array}$ & $\begin{array}{c}1980^{l} \\
1980=100\end{array}$ \\
\hline Australia & 13.6 & 14.9 & 14.8 & 15.9 & 17.8 & 4.2 & 131 \\
\hline Austria & 5.2 & 5.0 & 4.8 & 4.8 & 4.8 & -0.4 & 92 \\
\hline Belgium & $1.9^{2}$ & $2.3^{3}$ & 3.6 & 3.4 & 3.6 & 1.7 & 189 \\
\hline Canada & $11.2^{2}$ & 13.2 & 12.7 & 13.7 & 15.1 & 3.9 & 135 \\
\hline Denmark & nra & nra & ttia & $\mathrm{n} ; \mathrm{a}$ & 8.3 & nia & na \\
\hline Finland & $3.5^{\prime}$ & 4.9 & 63 & 7.9 & 9.2 & 5.7 & ${ }^{2} 65$ \\
\hline France & 0.8 & 1.0 & 2.0 & 2.1 & 2.3 & 1.5 & 296 \\
\hline Germans & 4.0 & 5.2 & 7.0 & 6.2 & 6.8 & 2.9 & 172 \\
\hline Greece & na & nla & 0.7 & 0.7 & 0.7 & na & n:'a \\
\hline Iceland' & nta & $\mathrm{n} \mathrm{a}$ & 3.8 & 3.6 & 3.7 & irrat & $\mathrm{n} \cdot \mathrm{a}$ \\
\hline Ireland & 8.8 & $10.2^{3}$ & 10.8 & 11.6 & 12.4 & 3.7 & 142 \\
\hline Italy & 3.4 & 3.8 & 4.6 & 4.6 & nla & 1.2 & 135 \\
\hline Japan & 1.2 & 1,2 & 0.8 & 0.8 & 0.7 & 0.5 & 59 \\
\hline Luxembourg & na & $2.8^{3}$ & $\mathrm{n} / \mathrm{a}$ & nia & 2.7 & $\mathrm{n} \% \mathrm{a}$ & nrz: \\
\hline Netherlands & 2.6 & $4.1^{3}$ & 3.8 & 3.7 & $\mathrm{n} \% \mathrm{a}$ & 1.1 & 143 \\
\hline New Zealand & 30.7 & 32.3 & 37.3 & 24.4 & 25.1) & $\ldots .5 .7$ & 82 \\
\hline Norway & 1.5 & 2.6 & 3.9 & 4.0 & 4.0 & & 271 \\
\hline Portugal' & 0.9 & 3.2 & 2.4 & 2.2 & 2.1 & 1.2 & 241 \\
\hline Spain & $\mathrm{n} \% \mathrm{a}$ & n'a & to & u. a & 2.7 & $\mathrm{n} t t$ & $\mathrm{n} \mathrm{a}$ \\
\hline Sweden & 4.1 & 6.4 & 6.0 & 6.2 & 6.8 & 2.7 & 164 \\
\hline Switzerland' & 1.8 & 2.0 & $\mathrm{n} / \mathrm{a}$ & 2.4 & 2.3 & 0.5 & 130 \\
\hline Turkey & na & na & na & nia & na & na & nia \\
\hline $\mathrm{UK}^{\prime}$ & 8.6 & 14.6 & 12.2 & 13.4 & 15.3 & 6.7 & 177 \\
\hline USA: FS & 8.4 & 8.3 & 8.0 & 8.9 & 10.0 & 1.5 & 118 \\
\hline $\begin{array}{l}\text { USA: (SSi } \pm \\
\text { AFDC) }\end{array}$ & 6.5 & 6.2 & 6.6 & 7.1 & 7.5 & 1.0 & 116 \\
\hline
\end{tabular}

Notes: See footnotes to Table 2.6.

Increases up to 1991 where no data for 1992

1981

1986

Categorical assistance schemes only

Excluding pension supplements

h Income Support only

Recipients of all non-contributory benefits

Sources: Data supplied by official and academic national informants

Most countries recorded a substantial expansion in the number of beneficiaries as a percentage of the population, especially Britain, Australia. Canada. Ireland. Germany and the Nordic countries. The proportionate increase was greatest in Scandinavia (except Sweden. although claimant numbers have grown substantially there since 1992) and in several EU states, including France. Germany, Belgium and Portugal. The expansion of coverage of the major schemes in the USA (with the exception of Earned Income Tax Credit) was one of the lowest in the OECD a likely reflection of the USA's record on job growth and unemployment. Overall. country differences in the coverage of social assistance narrowed over the period. In several there was a marked expansion in the early 1990 s.

\section{Types of assistance beneficiary}

It is difficult to obtain comparable data on the categories of assistance recipients, but Table 2.8 displays what information it has been possible to gather for four major groups: older people, disabled people, lone parents and the unemployed. These groups sometimes overlap and the table is dependent here on the statistical and classification systems adopted by different nations. Usually classification is based on whoever in the benefit unit actually makes the claim.. on the 'head of household', or on the 'key person'. In countries with a basic general safety-net scheme, the data are derived from official statistics on such schemes. In countries where categorical assistance programmes predominate, the numbers are usually equated with those receiving specific benefits. as detailed in Table 2.9. 
The numbers in each group are still expressed as a proportion of the total population, not the population in each category, since comparable information of this kind is not available for many of the countries. Thus the proportions in the table are influenced by the relative importance of each group in the national population. There are clearly limitations to this way of presenting the data, but given the wide divergences in programmes this at least ensures some level of comparability across countries. Some chapters on individual countries in Volume Two include further information on beneficiaries as a proportion of the particular population group.

Table 2.8: $\quad$ Main categories of social assistance beneficiaries, 1992

Social assistance beneficiaries in each category as "n of total national populations_Cash benefits only

\begin{tabular}{|c|c|c|c|c|}
\hline Country & Aged & Disabled & Lone parent & Unemployed \\
\hline Australia & 8.5 & 2.8 & 16 & 4.4 \\
\hline Austria` & 3.4 & $\mathrm{Ma}$ & 0.2 & 0.7 \\
\hline Belgium & 1.1 & 2.0 & 0.3 & $\mathrm{n} / \mathrm{a}$ \\
\hline Canada & 5.2 & 2.0 & 2.8 & 4.5 \\
\hline Denmark & n'a & $\mathrm{n} / \mathrm{a}$ & 2.9 & $\mathrm{Ma}$ \\
\hline Finland & $0.3^{\prime}$ & $\mathrm{II} / \mathrm{a}$ & $1.3^{\prime}$ & 3.8 \\
\hline France & $\mathrm{Ma}$ & 1.0 & 0.2 & nta \\
\hline Germany & 0.9 & 1.3 & 1.0 & 0.8 \\
\hline Greece & 0.3 & 0.6 & 0.4 & $\mathrm{Ma}$ \\
\hline Iceland & $6.8^{\prime}$ & 1.8 & $1.3^{\prime}$ & $\mathrm{Ma}$ \\
\hline Ireland & 3.2 & 0.8 & 0.9 & 6.2 \\
\hline Italy' & 1.3 & 2.2 & $\mathrm{n} / \mathrm{a}$ & nia \\
\hline Japan $^{4}$ & 0.3 & 0.3 & 0.1 & $\mathrm{n} / \mathrm{a}$ \\
\hline Luxembourg & 0.6 & 0.6 & 0.2 & nia \\
\hline Netherlands & 0.2 & nra & 0.8 & 2.1 \\
\hline New Zealand & 14.8 & 0.9 & 2.8 & 5.0 \\
\hline Norway & 0.2 & 0.4 & 1.0 & 1.2 \\
\hline Portugal & 1.3 & 0.5 & $\mathrm{n} / \mathrm{a}$ & nia \\
\hline Spain & 0.1 & 0.2 & $\mathrm{Ma}_{2}$ & 2.4 \\
\hline Sweden & 0.4 & $\mathrm{Ma}$ & (\} $.7^{2}$ & $\mathrm{n} / \mathrm{a}$ \\
\hline Switzerland & 1.8 & 0.5 & n'a & nia \\
\hline Turkey & $\mathrm{n}$ at & rva & $\mathrm{Ma}$ & nia \\
\hline UK & 3.3 & 1.2 & 4.7 & 5.1 \\
\hline USA & 0.6 & 1.6 & 4.8 & 0.5 \\
\hline
\end{tabular}

Notes; Total column taken from Table 2.6. col 3 unless otherwise stated. Columns do not necessarily sum to total.

Calculated from household data, assuming all are single person households

Estimated from number of households, assuming 1.5 children per adult 1991

4 Estimated from number of households by applying average ratio of beneficiaries to households for each year. derived from tables in Volume Two

Including recipients of supplementary pensions

Sources; Internal statistics of main general assistance scheme unless shown otherwise in Appendix Table (2.9) below 
Table 2.9: Definitions and sources of data for categorical schemes in Table 2.8

For countries not listed below, data comes from internal statistics of main general social assistance scheme

\begin{tabular}{|c|c|c|c|c|}
\hline Country & Aged & Disabled & Single parent & Lin 'iployea' \\
\hline Australia & Age pension and wifelcarer pensions & Disability Support Pension & Sole Parent Pension & $\mathrm{U} 13_{-}$JSA + NS \\
\hline Austria & Supplementary Pensions & & & Unemployment Assistance \\
\hline Belgium & Revenu Gorunti pour Personifies Agee.? & Allocation pour Hondieappes & Only those receiving Minimcx & \\
\hline Canada & $\begin{array}{l}\text { Guaranteed Income Supplement } \\
\text { Spouse's Allowance }\end{array}$ & & & \\
\hline France & 1W/nininonn Vieillessc & A/tocolions mix rld.tlaes Ilandicapes & Allocation pour Parent Isolu' & \\
\hline Germany & & Receiving Sodialhrlfe in institutions & $\begin{array}{l}\text { Female headed households with children } \\
\text { receiving, So:ialhilfe }\end{array}$ & $\begin{array}{l}\text { Receiving Soeioilrilfc and giving } \\
\text { unemployment as main reason }\end{array}$ \\
\hline Greece & Non-ic:nreil Older Person Scheme & Receiving disability benefits & Unprotected children scheme & \\
\hline Iceland & Rc eeivu2 pplr -:;;:ants to age pension & $\begin{array}{l}\text { Receiving supplements to invalid Y } \\
\text { pension }\end{array}$ & & \\
\hline Ireland & $\begin{array}{l}\text { Old Age Non-Contributory Pension } \\
\text { (including adult dependants only) }\end{array}$ & Disabled Persons Maintenance Allowance & $\begin{array}{l}\text { Lone Parent Allowance (excluding } \\
\text { dependants) }\end{array}$ & $\begin{array}{l}\text { Unemployment and Pre-retirement } \\
\text { Allowance (applicants only . excluding } \\
\text { dependants) }\end{array}$ \\
\hline Italy & l'ensione Soria\& & Disability pension & & \\
\hline Luxembourg & & $\begin{array}{l}\text { Allocation pour Personnnes Grarenttent } \\
\text { Ilanndieapes }\end{array}$ & & \\
\hline Netherlands & $\mathrm{ABW}, 65$ years and over & & $\mathrm{ABW}$ or RWW & Receiving RWW/WWW \\
\hline New Zealand & $\begin{array}{l}\text { National Superannuation }{ }^{\mathrm{s}} \text { Guaranteed } \\
\text { Retirement Income }\end{array}$ & Invalids Benefit & Domestic Purposes Benefit/ & Unemployment Benefit \\
\hline Norway & & $\begin{array}{l}\text { Receiving Social Economic Assistance } \\
\text { and elso Disability Pension }\end{array}$ & Receiving Transitional Allowance & \\
\hline Portugal & Old-age Social Pe ion & Invalidity Social Pension & & \\
\hline Spain & Non-contributory Pension & Disability Assistance & & Unemployment Assistance \\
\hline Switzerland & Supplementary Pension & Supplementary Pension & & \\
\hline USA & Supplementary Security Income (SST) & SSI & AFDC & AFDC-UP \\
\hline
\end{tabular}


Older recipients of means-tested benefits are. not surprisingly, numerous in Australia and New Zealand. which have no social insurance schemes, but also in the UK and Ireland, where assistance benefits supplement relatively low basic pensions. In the UK. for example. 20 per cent of Income Support recipients in 1993 were aged 60 or over. All these countries, except for Britain, have a lower relative share of older people, so that the impact of the benefit system is greater than these shares would suggest. Older recipients are relatively insignificant in most other countries. except for some European countries with means-tested social pensions built into or alongside the social insurance pensions, as in Belgium, Iceland, Italy and Portugal. In Sweden, for example. only two per cent of recipients in 1994 were over retirement age.

Assistance recipients with disabilities (and their families) constituted more than one per cent of the population in most countries for which we have data, and notably more in Italy. Belgium, Iceland. Australia, Canada and the USA.

One group for whom there is rather more information is that of lone parents. They formed a relatively large group of assistance beneficiaries in the USA. Canada, the UK and New Zealand. reflecting in part their incidence in the populations, and were significant also in Australia and Finland. Elsewhere they made fewer demands on social assistance in terms of their percentage of the overall populations, for reasons which vary according to the country, but include low numbers, their rate of labour participation and the relative success of other income maintenance systems in supporting separated parents with children. Nevertheless, they made up a significant proportion of all assistance claimants (as opposed to all beneficiaries) in a number of countries. In Iceland, for example, 35 per cent of recipients of Financial Assistance in 1992 were lone parents, while in the Netherlands they made up nearly half of all those receiving General Assistance (ABW) and around four per cent of Unemployment Assistance (RWW) recipients. Other countries with substantial assistance receipt by lone parents included Canada (around 27 per cent), Denmark (22 per cent), Austria (around 20 per cent) and Belgium, Germany and the UK (all around 18 per cent). In the USA. AFDC recipients, most of whom are lone parents. made up about 30 per cent of all assistance programme recipients. The AFDC claimant population overlaps with that of Food Stamps, however, so lone parents would constitute an even greater percentage of recipients overall. In most of the other countries, between nine and 15 per cent of recipients in 1992 were lone parents.

There is surprisingly little comparable information on the proportion of assistance beneficiaries who are unemployed. They were. however, the largest proportionate category of recipients for most countries where there was information. By 1992, unemployment was the cause of a significant demand for means-tested benefits across the OECD countries, but especially so in all the English-speaking countries except the USA.

One further pattern which emerges from the data collected for Volume Two is that in most countries between half and two-thirds of recipients in 1992 were single people and only around one-third of recipient families, on average, had children. What these data conceal, however, is the high proportion of women in the assistance-receiving populations of many of the countries in the study. Breakdowns of family types by sex are not available for all the countries, but it is noticeable that benefit units headed by single women and female lone parents made up between one-third and 60 per cent of all recipients in the countries for which we have information. In the Netherlands as many as 80 per cent of General Assistance and one-third of Unemployment Assistance recipients were women. Although, as we have seen, older people make up only a small proportion of assistance recipients in most countries, they are often single women. When these women are counted along with others in couple families, it is clear that what has been called the 'feminisation of poverty'. while varying among the countries studied, is a significant feature of social assistance provision in the OECD countries. 
Table 2.10 brings together the sparse information available on changes in the composition of social assistance beneficiaries. again as a proportion of total population rather than the particular population groups. This is supplemented with other information provided in the country studies in Volume Two.

Of the 11 countries with data on elderly recipients of social assistance. six exhibited a decline and one showed no change - only in New Zealand was there a significant growth. In Portugal the numbers declined after 1985 with the expansion of social insurance, and the same is likely to be true of Spain and Greece. Old age is. generally speaking, a diminishing reason for people to claim means-tested benefits - in absolute as well as relative terms. One exception to this pattern was Iceland. where changes in the structure of pensions brought a large number of older people into receipt of means-tested supplements.

Disability. by contrast, appears to have fuelled a growing demand for assistance payments in all countries for which we have information, except Japan (where overall numbers on assistance have fallen steadily). In the USA, Australia and Belgium ${ }^{\mathrm{g}}$ rowth in claims by disabled people has reflected both widening entitlements and more generous benefits. The rapid expansion in Italy is thought to be due partly to the use of disability benefits as a substitute for other contingencies. such as unemployment, for which there is no clear entitlement.

Table 2.10: Changes in main categories of beneficiaries 1980-1992

\begin{tabular}{|c|c|c|c|c|}
\hline Country & Aged & Disabled & Lone parent & Unemployed \\
\hline Australia & -0.8 & 0.8 & 0.8 & 2.3 \\
\hline Austria & -0.8 & & & 0.6 \\
\hline Belgium & 0.4 & 1.0 & & \\
\hline Canada & $-0.2^{1}$ & & & 4.1 \\
\hline \multicolumn{5}{|l|}{ Denmark } \\
\hline Finland & & & 0.5 & \\
\hline France & & 0.3 & 0.1 & \\
\hline Germany & -0.1 & 0.4 & 0.4 & 0.6 \\
\hline Greece & -0.1 & & & \\
\hline \multicolumn{5}{|l|}{ Iceland } \\
\hline \multicolumn{5}{|l|}{ Ireland } \\
\hline Italy & & 1.3 & & \\
\hline Japan & --0.1 & 0.3 & --0.1 & \\
\hline Luxembour $^{\mathrm{g}}$ & & & 0.3 & \\
\hline Netherlands- & -0.7 & & --0.4 & 1.3 \\
\hline New Zealand & 1.9 & 0.4 & 1.7 & 4.3 \\
\hline Norway & 0.0 & & 0.7 & \\
\hline Portugal & 0.6 & 0.4 & & \\
\hline Spain' & & & & 2.1 \\
\hline Sweden & & & $0.3^{2}$ & \\
\hline Switzerland & 0.3 & 0.2 & & \\
\hline \multicolumn{5}{|l|}{ Turkey } \\
\hline $\mathrm{UK}^{4}$ & -0.3 & 0.7 & 2.9 & 0.4 \\
\hline USA & --0.2 & 0.6 & 0.4 & 0.3 \\
\hline
\end{tabular}

Notes: See Table 2.9 for sources and definitions.

Only refers to decrease in number at Spouse's Allowance recipients

Increase to 1991

Increase from 1982

Increase from 1981

Beneficiaries of Arheitslosenhilfe

Consistent time-series data on lone parent recipients are available for 12 countries, and there is some evidence on other countries in the individual chapters in Volume Two, I.n all, except japan and the Netherlands, a growing number of claimants are single parents. and this is also true for Austria and Ireland. Their expansion has been especially dramatic in Britain and New Zealand, though not, surprisingly, in 
the USA. In Australia and New Zealand the rise has been fuelled by rising numbers and more generous entitlements and benefits.

It is, however, unemployment which appears to be the principal cause of the rising social assistance clientele since $1980^{1}$. Data on unemployed claimants are sparse, but this pattern holds for all the countries in Table 2.10, except the USA and the UK. The country reports in Volume Two show that this is also true for Finland and Sweden in recent years and for Ireland throughout the period. It has pushed another four per cent of New Zealanders and Canadians on to social assistance over the last decade.

The impact of unemployment on social assistance claims is mediated by country differences in entitlements, the range and generosity of alternative benefits and changes in the definitions of unemployment. In Germany, and several other countries, it is the growth of long-term unemployment which has had the greatest impact. In Canada. recent cuts in unemployment insurance have led to more people claiming under the Assistance Plan, whereas in Denmark rising unemployment has had little impact on the demand for assistance because of a new non-contributory benefit. In New Zealand, the growth of unemployed claimants has been fuelled by a combination of rapidly rising numbers, more generous entitlements and benefits, and a rising take-up rate. On the other hand, the number of out-of-work recipients in the Netherlands has fallen since 1984 (this is hidden in Table 2.10) and those in the UK have risen only slightly, despite a big increase in unemployment in both countries since 1979. In both cases this is probably due to the removal of young persons from social assistance onto special employment schemes.

\subsection{Conclusion}

This chapter has described the pattern of expenditures on, and recipients of, social assistance in 1992 and trends in each since 1980, in so far as comparable data have been available. Certain national patterns have begun to emerge which will be fleshed out in subsequent chapters. In the final chapter we return to the issue of welfare regimes and propose an overall typology to make sense of the national variations across the OECD world. In spite of the differences. common trends have been uncovered. The share of social assistance expenditures expanded in every country, except Japan and Switzerland, during the 1980s and early 1990s, while over the same period the proportion of the population receiving assistance benefits rose in every country except Japan, Austria and New Zealand. The growth of unemployment and of lone parenthood appeared to be the main significant factors in this expansion, though expansion of provision for disabled people, as well as some use of disability payments in lieu of unemployment benefits, also contributed. Generally older people are becoming less likely to have to rely on social assistance, although changes in pension structures in a few countries have increased the numbers of older people receiving means-tested supplements. A significant proportion of recipient families are headed by women.

The next chapter looks in more detail at the basic principles and structures of assistance schemes.

Though care must be exercised in comparing particular years, since the business cycle affects demand for benefits, something not accounted for in Table 2.10. 


\section{Chapter 3 The Structure and Principles of Social Assistance Schemes}

\subsection{Introduction}

Chapter Two looked at ways of classifying the various income-related and meanstested benefits provided by the countries in the study and showed that the role of social assistance expanded in most OECD member countries during the 1980s. We now move on to compare the structure of these benefits and the rules governing eligibility and entitlement, looking at how far common principles and practices can be discerned across schemes, the level of policy convergence or divergence and explanations for differing or unusual policy approaches.

We saw earlier that social assistance regimes have been classified according to their position on four continua - general versus categorical, income maintenance versus social work, legal rights versus discretion, and central versus local (Lodemel and Schulte. 1992). These are important dimensions of analysis for trying to create primary groupings among countries, but it could be argued that the four criteria are both insufficiently comprehensive and simultaneously too broad in themselves to capture the full extent of similarity and variation between schemes. This chapter takes a more multi-dimensional approach to the structure of assistance, looking at the underlying principles; basic conditions of eligibility; inclusion and exclusion; legal rights and discretion; units of entitlement and assessment; and resource testing. It also examines how different schemes deal with housing costs and with exceptional needs.

We start by considering the basic aims and principles of assistance schemes.

\subsection{Aims and principles}

The purposes of social assistance schemes are generally outlined in legislation or policy statements, and a number of countries with written constitutions have included within them some expression of the obligation of the state to guarantee its citizens a minimum standard of living. Australia is one of the countries which expresses most directly the links between social assistance and wider economic and social objectives, subjecting policy proposals and amendments affecting meanstested benefits to annual review for their contribution to a wider strategy of Social Justice'. However, this explicit link is perhaps made partly because all benefits are of the assistance type.

Government respondents were asked for a statement of policy aims on social assistance. Those provided, which included both statements enshrined in laws and constitutions and expressions of policy by officials. were fairly similar across the whole range of countries. They basically encompassed three main principles:

1. the schemes are there to guarantee a minimum standard of living to people whose incomes are insufficient

2. people must lack the ability to support themselves adequately by other means or by access to other resources

3. schemes are not meant to encourage dependency but should incorporate measures to promote self-sufficiency and independence.

The relative emphasis placed on these three principles varies between countries, as does the definition, in so far as it is given. of the 'minimum'. In some countries, 
including Austria, Germany and Luxembourg, reference is made to 'decent' standards or those in keeping with human dignity': others refer to 'reasonable' or 'adequate' resources. As Chapter Five explains, the basis for the establishment of the reference minimum for assistance schemes differs widely between countries.

Several, especially the Northern European and Nordic countries. place a particular. expressed emphasis on the principle of 'subsidiarity', or the necessity of drawing upon all other available help or resources before being entitled to public assistance. However, the practical application of this principle again varies considerably, both in terms of the range and level of' personal resources which are exempted from means testing and in the extent to which it is expected that the resources of other people should be called upon before an individual has a right to public assistance.

Around half of all the countries explicitly state that one of the purposes or functions of assistance is to promote self-reliance and social integration, but no clear pattern emerges amongst these countries: they include representatives of all regime types. including both Australia and New Zealand, where all benefits are income-related or means-tested, and others where assistance benefits are a minor element of social security.

One indication of how serious a country is about restricting long-term dependence on assistance is whether duration on benefits can be time-limited. However, there is a basic conflict here between the promotion of independence and the provision of a last-resort safety net. Thus, although time limits have been introduced or tightened in several countries for entitlement to unemployment insurance or assistance, limits in general assistance schemes are untypical. The exceptions include mainly those countries with more discretionary or less comprehensive schemes, including Spain, Italy (for non-elderly and able-bodied people), Austria, Denmark, Switzerland and Turkey (where assistance is generally assumed to be temporary and time limits are discretionary), France (the RMI and some of the social minima) and the USA (General Assistance only, in some states). A number of other countries impose time limits on some of their categorical schemes, including Portugal and New Zealand (Job Search Allowance for those aged 16-17), but mainly these limits relate to age or duration in a particular population category. Once entitlement has expired claimants can often become eligible for a different benefit.

Overall, there seems to be little sign of any general movement towards limited duration in assistance, partly because, in spite of a widespread concern about the consequences of long-term dependence on benefits, it is the pressures of unemployment and social change which are leading to longer-term claiming. In these circumstances the imposition of time limits risks defeating the purpose of a safety net. The emphasis is therefore more on work incentives and job promotion. as discussed in Chapter Seven. Even in the USA, where the Clinton administration has taken a tough line on welfare and has proposed to limit receipt of AFDC to two years, it is recognised that this can only work if the jobs programme element of the package is made much more effective (Finn, 1994).

Policy principles for social assistance schemes are inevitably presented at a somewhat rhetorical level and the formal similarity in aims disguises considerable differences between countries, particularly, as we show later in this chapter, in the extent of coverage offered by the benefits available and in the practical interpretation of the requirement to exhaust other resources.

Establishing a claim for a social assistance benefit almost invariably requires a twostage process of assessment. First it has to be determined whether an applicant is eligible for the benefit --- that is, whether s/he falls into a category of person for whom the benefit is intended. This might be by reference to age, family type. labour market status or hours of work, residence or nationality, or various other criteria. Secondly, if eligibility has been established, it then has to be determined whether the claimant is entitled to benefit on the basis of their needs and their resources. We look first at conditions of eligibility. 


\subsection{Conditions of eligibility}

Table 3.1, stretching over the next few pages, provides a broad, comparative outline of some of the main conditions of eligibility for the resource-tested benefits in the countries studied. The picture provided is inevitably over-simplified and partial: for more detail the reader should turn to the individual country reports in Volume Two. However. this form of graphic presentation helps to illuminate patterns of similarity and difference. We concentrate here on income-related or means-tested benefits providing either general or group-specific cash help. and exclude the separate 'tied' benefits, such as housing support. The table includes both what were described in the last chapter as 'poverty-tested' benefits and the other important allowances which go further up the income scale. It also indicates whether the main general minimum income benefit available is organised predominantly on a national or a sub-national basis and whether it is primarily rights-based or discretionary. The table shows the main features of eligibility, including the target population group. the minimum (or maximum) age for individual eligibility, the main residence or nationality requirements_ whether there are work-seeking requirements, any limits to the number of hours claimants can work and still receive benefit, and any other important country- or benefit-specific criteria. Availability for work requirements are discussed in more detail in Chapter Seven. 
Table 3.1: Main conditions of eligibility for income-related and means-tested benefits in the OECD countries

\begin{tabular}{|c|c|c|c|c|c|c|c|c|}
\hline £'ountry & General benefits & Categorical benefits & "Target group & Minimum (max.) age & Residence/nationality & Work tests & Working hours limit & Other \\
\hline \multirow[t]{10}{*}{ Australia } & $\begin{array}{l}\text { Special Benefit' } \\
\text { (national, regulated) }\end{array}$ & & $\begin{array}{l}\text { People with severe } \\
\text { financial needs and no } \\
\text { other entitlements }\end{array}$ & 16 & Resident of and in Australia & Yes & No & \\
\hline & & Job Search allowance & $\begin{array}{l}\text { Unemployed under } 18 \text { or } \\
\text { in first year of } \\
\text { unemployment }\end{array}$ & $\begin{array}{l}16 \text { ( } 60 \text { women, } 65 \\
\text { men) }\end{array}$ & & Yes & full-time work & \\
\hline & & New Start Allowance & $\begin{array}{l}\text { Unemployed over } 18 \text { or } \\
\text { alter } 1 \text { year }\end{array}$ & $\begin{array}{l}18 \text { ( } 60 \text { women, } 65 \\
\text { men) }\end{array}$ & & $\begin{array}{l}\text { Yes (unless } \\
\text { over 60) }\end{array}$ & I uï timis , r:: & \\
\hline & & Age Pension & Older people & 60 or 65 & $\begin{array}{l}10 \text { years residence, } \\
\text { including } 5 \text { continuously }\end{array}$ & No & $\because$ & \\
\hline & & Service Pension & Veterans & 55 women, 60 men & $\begin{array}{l}\text { Resident of and in Australia } \\
\text { (10 years for Allied or } \\
\text { Commonwealth vets. })\end{array}$ & No & $\therefore$ & \\
\hline & & $\begin{array}{l}\text { Disability Support } \\
\text { Pension }\end{array}$ & Disabled people & $16(60$ or 65$)$ & $\begin{array}{l}\text { Either Aus, resident when } \\
\text { incapacity started, or } 10 \\
\text { years residence, or } \\
\text { dependent child of resident }\end{array}$ & No & 30 hours per week & $\begin{array}{l}\text { At least } 20 \% \\
\text { impairment and } \\
\text { continuing incapacity } \\
\text { for work }\end{array}$ \\
\hline & & Wife Pension & $\begin{array}{l}\text { Partners of age or } \\
\text { disability pensioners }\end{array}$ & $\begin{array}{l}\text { 21, unless claimant or } \\
\text { partner has child }\end{array}$ & None & No & No & \\
\hline & & Carer Pension & $\begin{array}{l}\text { Resident carers of } \\
\text { severely disabled people }\end{array}$ & $(60$ or 65$)$ & Must be in Australia & No & 10 hours per week & $\begin{array}{l}\text { Must be providing } \\
\text { constant care in the } \\
\text { person's home and be } \\
\text { living with or next to } \\
\text { them. }\end{array}$ \\
\hline & & Sickness Allowance & Short-term sick & 16(60or65) & Resident of and in Australia & No & $\begin{array}{l}8 \text { hours per week if } \\
\text { unemployed }\end{array}$ & \\
\hline & & $\begin{array}{l}\text { Sole Parent Pension } \\
\text { Also:- } \\
\text { Family Payments }\end{array}$ & Lone parents & No minimum age & $\begin{array}{l}\text { Resident at becoming sole } \\
\text { parent, or } 5 \text { years } \\
\text { continuous residence, or } 10 \\
\text { years overall }\end{array}$ & No & No & $\begin{array}{l}\text { Must seek child support } \\
\text { from ex-partner }\end{array}$ \\
\hline
\end{tabular}




\begin{tabular}{|c|c|c|c|c|c|c|c|c|}
\hline Country & General benefits & Categorical benefits & Target gn)up & Minimum (max.) age & Residence/nationality & Work tests & Working hours limit & Other \\
\hline \multirow[t]{3}{*}{ Austria } & $\begin{array}{l}\text { Sozialbille } \\
\text { (Provincial; } \\
\text { discretionary) }\end{array}$ & & General & 14 & $\begin{array}{l}\text { Residence in relevant } \\
\text { province. Some provinces } \\
\text { also require Austrian } \\
\text { citizenship, but Eli } \\
\text { nationals and recognised } \\
\text { refugees also covered }\end{array}$ & $\begin{array}{l}\text { Yes, unless } \\
\text { e xe } 111171\end{array}$ & No & \\
\hline & & $\begin{array}{l}\text { Unemployment } \\
\text { Assistance }\end{array}$ & $\begin{array}{l}\text { Unemployed whose } \\
\text { entitlement to insurance } \\
\text { benefit has expired }\end{array}$ & (retirement. age) & & Yes & $\mathrm{l}^{=}$ull-time work & \\
\hline & & $\begin{array}{l}\text { Supplementary } \\
\text { Pensioi, i }\end{array}$ & $\begin{array}{l}\text { Older people whose } \\
\text { insurance pensions } \\
\text { are below minlrnurn }\end{array}$ & Retirement age & & No & No & Contributory \\
\hline \multirow[t]{3}{*}{ Belgium } & $\begin{array}{l}\text { Minimex } \\
\text { (national, regulated) }\end{array}$ & & General & $\begin{array}{l}18 \text { (unless parent or } \\
\text { pregnant.) }\end{array}$ & $\begin{array}{l}\text { 13ebtian and EU (titbit is, } \\
\text { pins accepted refugees. } \\
\text { Must also be registered as } \\
\text { resident in municipality }\end{array}$ & $\begin{array}{l}\text { Yes, unlcs } \\
\text { exempt }\end{array}$ & No & \\
\hline & & $\begin{array}{l}\text { Revemt Garanti noun } \\
\text { Personnes Agees }\end{array}$ & Older people & $\begin{array}{l}6 £ \mathrm{I} \text { (women) } \\
65 \text { (men) }\end{array}$ & $\begin{array}{l}\text { Citizenship (incl. ELI), plus } \\
\text { residence for } 5 \text { years before } \\
\text { claim or It) during life } \\
\text { Same (with some } \\
\text { exceptions) }\end{array}$ & No & No & \\
\hline & & $\begin{array}{l}\text { Allocation pour } \\
\text { Handicappes } \\
\text { Allocation } 1^{-} \text {amiliale } \\
\text { (i aranti }\end{array}$ & $\begin{array}{l}\text { Disabled people } \\
\text { Families/children }\end{array}$ & $\begin{array}{l}20(65) \\
\text { (18 or end of full- } \\
\text { ti me education.) }\end{array}$ & $\begin{array}{l}\text { No nationality condition, } \\
\text { but } 5 \text { year parental } \\
\text { residence }\end{array}$ & $\begin{array}{l}\text { No } \\
\text { No }\end{array}$ & $\begin{array}{l}\text { No } \\
\text { No }\end{array}$ & \\
\hline Canada & $\begin{array}{l}\text { Canada Assistance Plan } \\
\text { (Provincial, regulated) }\end{array}$ & $\begin{array}{l}\text { Guaranteed Income } \\
\text { Supplement and } \\
\text { Spouse's Allowance } \\
\text { it in } 3 \text { provinces, in- } \\
\text { work benefits }\end{array}$ & $\begin{array}{l}\text { Older people } \\
\text { Low income families in } \\
\text { work }\end{array}$ & $\begin{array}{l}18 \text { or } 19, \text { depending } \\
\text { on Province }\end{array}$ & $\begin{array}{l}\text { Residence in Canada. Some } \\
\text { provinces also require } \\
\text { minimum period of } \\
\text { residence in province or } \\
\text { municipality. } \\
\text { Accepted refugees eligible }\end{array}$ & $\begin{array}{l}\text { Yes, if } \\
\text { regarded as } \\
\text { 'employable' }\end{array}$ & & \\
\hline Denmark & $\begin{array}{l}\text { Social Bistatnd } \\
\text { (local, regulated/ } \\
\text { discretionary) }\end{array}$ & & General & $\begin{array}{l}25(66) \\
\text { Youth allowance for } \\
\text { those } 18 . .24\end{array}$ & $\begin{array}{l}\text { Danish or Nordic citizen. } \\
\text { and refugees. EU citiz . is ' ' } \\
\text { resident for } 3 \text { years }\end{array}$ & $\begin{array}{l}\text { Yes. } \\
\text { Special work } \\
\text { integration } \\
\text { schemes for } \\
\text { young people }\end{array}$ & $\begin{array}{l}\text { Not eligible if' in } \\
\text { full-tithe work }\end{array}$ & $\begin{array}{l}\text { Must have been subject } \\
\text { to major event affecting } \\
\text { ability to earn a living }\end{array}$ \\
\hline
\end{tabular}




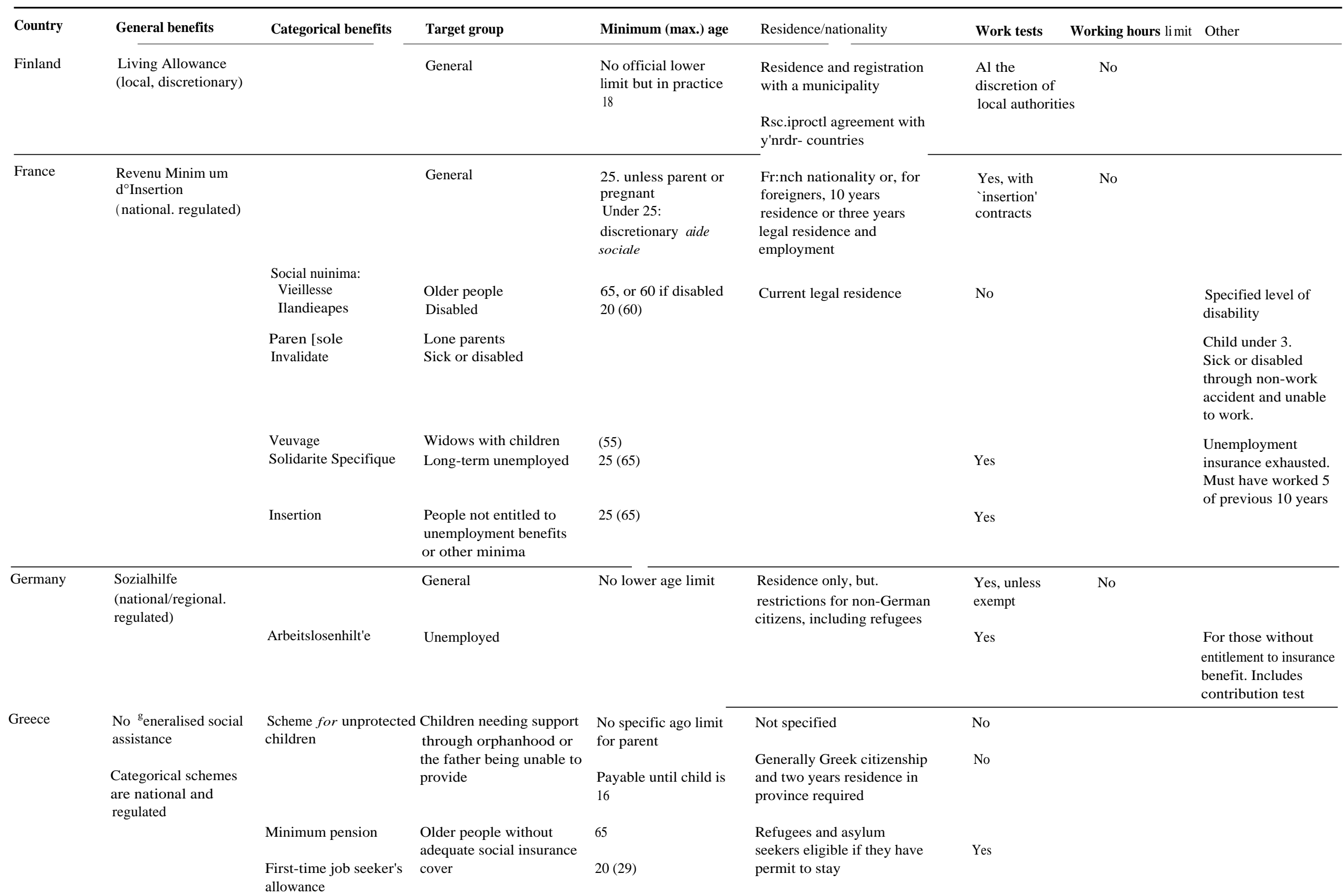


3itble 3.1: Main conditions of eligibility for come-related and means-tested benefits in the OECD countries (contd.)

\begin{tabular}{|c|c|c|c|c|c|c|c|c|}
\hline Country & General benefits & Categorical benefits & Target group & Minimum (max.) age & Residemelnationality & Work tests & Working hours limit & Other \\
\hline \multirow[t]{2}{*}{ Iceland } & \multirow[t]{2}{*}{$\begin{array}{l}\text { Financial Assistance } \\
\text { (local, regulated, } \\
\text { discretionary) }\end{array}$} & & General & 16 & $\begin{array}{l}\text { Legal residence } \\
\text { Reciprocal agreements with } \\
\text { Nordic countries }\end{array}$ & $\begin{array}{l}\text { Yes unless } \\
\text { exempted } \\
\text { (though varies } \\
\text { by area) }\end{array}$ & No & \\
\hline & & $\begin{array}{l}\text { Supplementary } \\
\text { retirement and } \\
\text { invalidity pensions }\end{array}$ & $\begin{array}{l}\text { Pensioners with little or } \\
\text { no incomes besides } \\
\text { minimum insurance } \\
\text { pensions }\end{array}$ & $\begin{array}{l}67 \text { or } 16(66) \text { for } \\
\text { invalidity }\end{array}$ & & No & No & $\begin{array}{l}\text { For invalidity, working } \\
\text { capacity must have } \\
\text { been reduced by at } \\
\text { least. } 75 \text { per cent }\end{array}$ \\
\hline \multirow[t]{13}{*}{ Ireland } & \multirow[t]{13}{*}{$\begin{array}{l}\text { Supplementary Welfare } \\
\text { Allowance } \\
\text { (national, regulated) }\end{array}$} & & General & 18 & Residence in Ireland & $\begin{array}{l}\text { Yes, if } \\
\text { circumstances } \\
\text { permit }\end{array}$ & $\begin{array}{l}\text { Must not he in full- } \\
\text { time work ( } 30 \mathrm{hrs} \\
\text { per week) }\end{array}$ & \\
\hline & & $\begin{array}{l}\text { Unemployment } \\
\text { Assistance }\end{array}$ & Unemployed & 18 & & Yes & $\begin{array}{l}\text { Up to } 3 \text { days work. } \\
\text { per week }\end{array}$ & \\
\hline & & $\begin{array}{l}\text { Pre-retirement } \\
\text { Allowance }\end{array}$ & $\begin{array}{l}\text { Unemployed over } 55 \\
\text { years }\end{array}$ & 55 & & No & $\begin{array}{l}\text { Must not have } \\
\text { earnings over } £ 25 \\
\text { per week }\end{array}$ & \multirow[t]{11}{*}{$\begin{array}{l}\text { Must have received } \\
\text { unemployment } \\
\text { assistance for i5 } \\
\text { months }\end{array}$} \\
\hline & & Old Age Pension & Older people & 66 & & No & No & \\
\hline & & $\begin{array}{l}\text { Blind Person's } \\
\text { Pension }\end{array}$ & Blind people & 18 & & No & No & \\
\hline & & Widow's Pension & $\begin{array}{l}\text { Widows who have not } \\
\text { remarried. }\end{array}$ & 18 & & No & No & \\
\hline & & $\begin{array}{l}\text { Deserted Wife's } \\
\text { Allowance }\end{array}$ & $\begin{array}{l}\text { Women deserted by } \\
\text { husband. }\end{array}$ & $4 t)$ & & No & No & \\
\hline & & $\begin{array}{l}\text { Prisoner's Wife's } \\
\text { Allowance }\end{array}$ & $\begin{array}{l}\text { Women with husband in } \\
\text { prison for } 6 \text { months or } \\
\text { more. }\end{array}$ & 40 & & No & No & \\
\hline & & Orphan's Allowance & Orphans & $\begin{array}{l}\text { ( } 18 \text { or } 21 \text { if in full- } \\
\text { time education) }\end{array}$ & & No & No & \\
\hline & & Carer's Allowance & $\begin{array}{l}\text { Full-time } \mathrm{c} \text { a ors of } \\
\text { pensioners or } \\
\text { disabled people }\end{array}$ & 18 & & No & $\begin{array}{l}\text { Must not be in } \\
\text { employment outside } \\
\text { the home }\end{array}$ & \\
\hline & & $\begin{array}{l}\text { Lone Parent } \\
\text { Allowance }\end{array}$ & \multicolumn{2}{|c|}{$\begin{array}{l}\text { l., one parent or prisoner's } 18 \\
\text { wile with chi.ld(ren) }\end{array}$} & & No & No & \\
\hline & & $\begin{array}{l}\text { Disabled Person's } \\
\text { Maintenance }\end{array}$ & $\begin{array}{l}\text { Disabled for at least } 1 \\
\text { year }\end{array}$ & $16(65\}$ & & No & $\begin{array}{l}\text { Must be verified as } \\
\text { arable to work }\end{array}$ & \\
\hline & & $\begin{array}{l}\text { Allowance } \\
\text { Family Income } \\
\text { Supplement }\end{array}$ & $\begin{array}{l}\text { Working families } \\
\text { with child. en }\end{array}$ & 18 & & No & $\begin{array}{l}\text { Must be working at } \\
\text { least } 20 \text { hours pax. }\end{array}$ & \\
\hline
\end{tabular}


Table 3.1: Main conditions of eligibility for incot elated and means-tested benefits in the OECD countries . (contd.

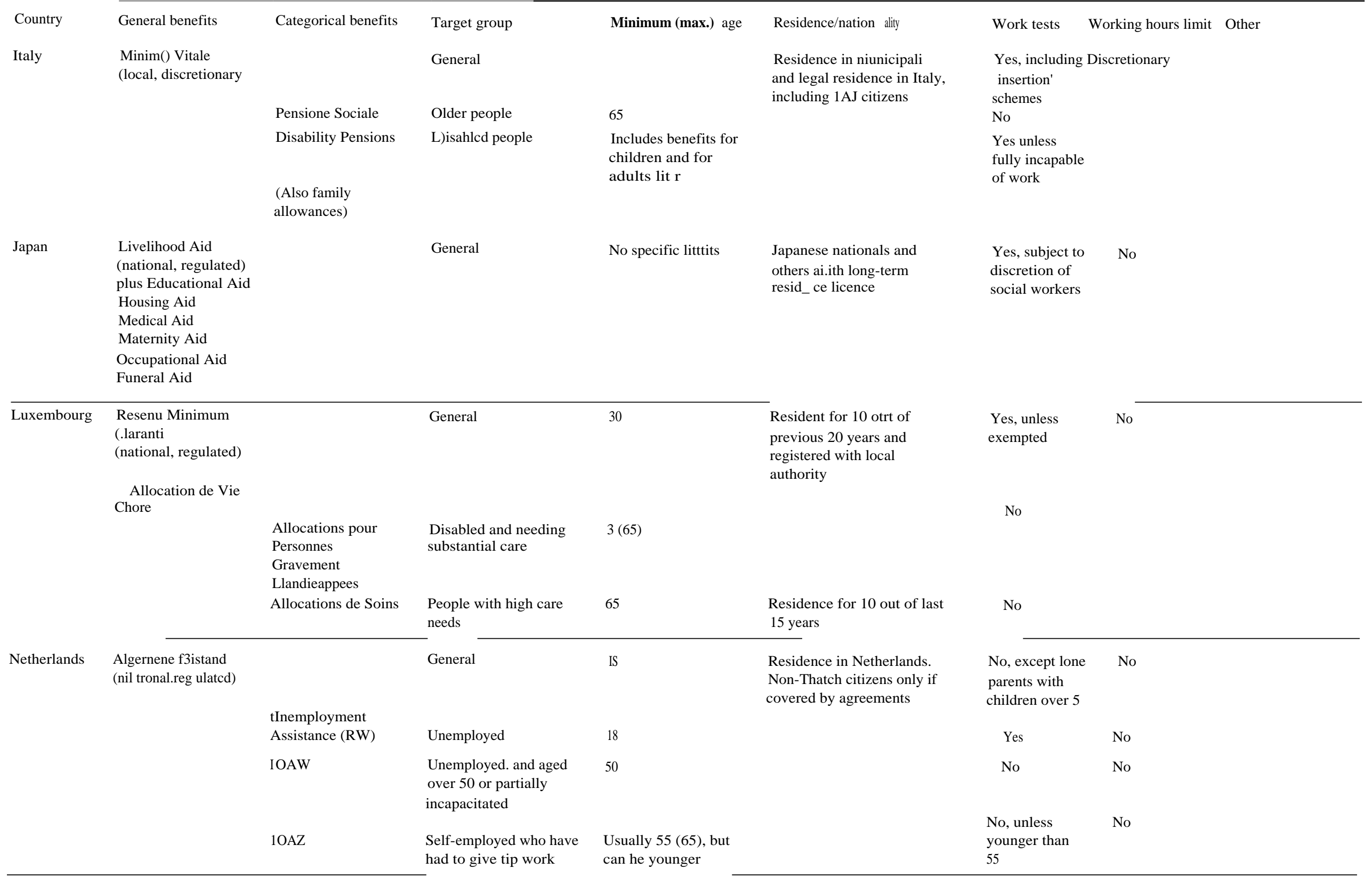




\begin{tabular}{|c|c|c|c|c|c|c|c|}
\hline Country & General benefits & Categorical benefits & Target group & Minimum (maxi) age & Residenceinationality & Work tests & Working hours limit Other \\
\hline \multirow[t]{10}{*}{ New Zealand } & $\begin{array}{l}\text { Special Benefit' } \\
\text { (national, regainted) }\end{array}$ & $\begin{array}{l}\text { 1.Jnem loyment } \\
\text { Benefits: }\end{array}$ & General & 16 & Current residence & Yes & No \\
\hline & & L'B & Unemployed & 15 & 12 months prior residence & Yes & \\
\hline & & $\begin{array}{l}\text { independent } \\
\text { Youth Benefit }\end{array}$ & Young unemployed & $16(17)$ & & Yes & \\
\hline & & $55+$ benefit & Older unemployed & 55 & & $\begin{array}{l}\text { Yes, but less } \\
\text { stringent. }\end{array}$ & \\
\hline & & Train inis Benefit & $\begin{array}{l}\text { People on short training } \\
\text { courses }\end{array}$ & 16 & & Training & Yes \\
\hline & & Sickness Benefit & Short-term sick & 16 & t0 years prior & No & Yes \\
\hline & & invalid Benefit & $\begin{array}{l}\text { Permanently } \\
\text { incapacitated }\end{array}$ & 16 & 5 years prior & No & \\
\hline & & $\begin{array}{l}\text { Domestic Purposes } \\
\text { Benefit }\end{array}$ & $\begin{array}{l}\text { Lone parents, divorced or } \\
\text { separated women over } \\
\text { 50. or non-spouse carers }\end{array}$ & 18 or 50 & & No & No \\
\hline & & Widows' benefit & Widows & 16 & 5 years prior & No & \\
\hline & & $\begin{array}{l}\text { Transitional } \\
\text { Retirement } \\
\text { Benefit }\end{array}$ & $\begin{array}{l}\text { Retired people not yet } \\
\text { entitled to } \\
\text { superannuation }\end{array}$ & 60 & 10 years prior & No & \\
\hline \multirow[t]{2}{*}{ Norway } & $\begin{array}{l}\text { Social Economic. } \\
\text { Assistance }\end{array}$ & & General & 18 & $\begin{array}{l}\text { Legal residents, plus other } \\
\text { Nordic citizens }\end{array}$ & Yes & No \\
\hline & & Transitional Allow-am: & $\begin{array}{l}\text { Lone parents (with } \\
\text { children tinder 10) }\end{array}$ & 18 & & $\begin{array}{l}\text { Yes, but only } \\
\text { when youngest } \\
\text { child hers } \\
\text { finished school } \\
\text { year after } \\
\text { reaching } 10 \\
\text { years }\end{array}$ & 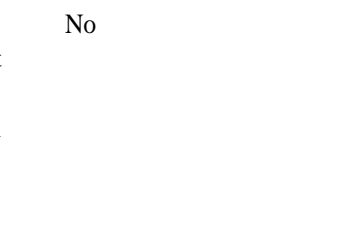 \\
\hline
\end{tabular}




\begin{tabular}{|c|c|c|c|c|c|c|c|c|}
\hline Country & General benelits & Categorical benefits & Target group & Minh-man & Residencelnationality & Work teas & Working looms liiii t & Other \\
\hline \multirow[t]{10}{*}{ Portugal } & (national,rcgulated) & Family Allowance & Families/children & $\begin{array}{l}14 \text { for independent } \\
\text { claims (up to } 25 \text { if in } \\
\text { full-time education) } \\
\text { (18) }\end{array}$ & $\begin{array}{l}\text { Resident nationals of } \\
\text { Portugal, plus resident EU } \\
\text { citizens and others where } \\
\text { bilateral agreement exists }\end{array}$ & No & No & \\
\hline & & $\begin{array}{l}\text { Supplementary } \\
\text { Allowance }\end{array}$ & $\begin{array}{l}\text { Disabled children \& } \\
\text { young; people }\end{array}$ & & & & & \\
\hline & & Constant Attention & For those receiving & & & & & \\
\hline & & Allowance & Stapp. Allowance & 16 & & & & \\
\hline & & $\begin{array}{l}\text { Integration Benefit } \\
\text { Social Pension }\end{array}$ & & 18 & & $\begin{array}{l}\text { Yes } \\
\text { No }\end{array}$ & & \\
\hline & & & people & & & & & \\
\hline & & $\begin{array}{l}\text { Special Education } \\
\text { Allowance }\end{array}$ & $\begin{array}{l}\text { To cover costs of } \\
\text { special education }\end{array}$ & & & & & \\
\hline & & Nursing Allowance & Maternity costs & (18) & & & & \\
\hline & & Orphan's Pension & Orphans & & & & & \\
\hline & & Survivor's Grant & Survivors & & & & & \\
\hline \multirow[t]{4}{*}{ Spain } & $\begin{array}{l}\text { Ingreso Minimo } \\
\text { d'Insercion } \\
\text { (regional, regulated) }\end{array}$ & & General & $25(65)$ & $\begin{array}{l}\text { No nationality condition } \\
\text { but min. of } 1 \text { year residence } \\
\text { in region. Also applies to } \\
\text { EU citizens }\end{array}$ & $\begin{array}{l}\text { Yes. if } \\
\text { economically } \\
\text { active }\end{array}$ & No & \\
\hline & & $\begin{array}{l}\text { Unemployment } \\
\text { Assistance }\end{array}$ & $\begin{array}{l}\text { Unemployed people not } \\
\text { entitled to insurance } \\
\text { benefit }\end{array}$ & $\begin{array}{l}\text { Single } 45 \text { (651 } \\
\text { with family } 18 \text { (65) }\end{array}$ & Legal residence & Yes & No & $\begin{array}{l}\text { Also depends on } \\
\text { length of time since } \\
\text { insurance exhausted } \\
\text { and on contributions }\end{array}$ \\
\hline & & Social Pension & $\begin{array}{l}\text { Older people without } \\
\text { insurance pensions }\end{array}$ & 65 & $\begin{array}{l}10 \text { years residence in Spain } \\
\text { (including } 2 \text { preceding } \\
\text { claim) }\end{array}$ & No & & \\
\hline & & Disability Pension & $\begin{array}{l}\text { Disabled people without } \\
\text { insu'ance cover }^{\text {ra }}\end{array}$ & $18(65)$ & 5 years residence in Spain & No & & $\begin{array}{l}\text { Minimum 65"/+, } \\
\text { incapacity }\end{array}$ \\
\hline Sweden & $\begin{array}{l}\text { Social Welfare } \\
\text { Allowance } \\
\text { (local, discretionary) }\end{array}$ & & General & $\begin{array}{l}\text { In principle } 15 \text {, but } \\
\text { normally } 18\end{array}$ & $\begin{array}{l}\text { Legal residence in Sweden, } \\
\text { Reciprocal arrangements } \\
\text { with Nordic countries }\end{array}$ & Yes & No & \\
\hline \multirow[t]{2}{*}{ Switzerland $^{\mathrm{nm}}$} & $\begin{array}{l}\text { Soziale Ftirsorge/Aide } \\
\text { Sociale } \\
\text { (local, discretionary) }\end{array}$ & & General & No specific age limit & $\begin{array}{l}\text { Swiss citizens and legally } \\
\text { resident foreigners. } \\
\text { Entitlement based on } \\
\text { cantonal residence }\end{array}$ & $\begin{array}{l}\text { Yes, unless } \\
\text { exempt }\end{array}$ & No & \\
\hline & & insurance age and & & & & & & Contributory \\
\hline
\end{tabular}


Table 3.1: Main conditions of eligibility for income-rebated and means-tested benefits in the OECD countries

Country

\begin{tabular}{llll} 
General benefits & Categorical benefits & Target group & Minimum (max.) age \\
\hline $\begin{array}{l}\text { Social Assistance and } \\
\text { Solidarity Scheme } \\
\text { (national, regulated) }\end{array}$ & General & 18 \\
\hline & &
\end{tabular}

Residence/nationality

Ail resident
refugees

(national, regulated)

Old Age and Disability Older and disabled

Assistance people not covered by

insurance schemes

Also

Green Card scheme

Assistance for actor

and musicians

Two other small

schemes for children

students etc in need

\begin{abstract}
Income Support
\end{abstract}
(national, regulated)

Medical costs

65 for older people

18 (65) for disabled

Turkish nationals

No

Yes, within

capacities

ork teats

Working hours lim

N ?

Must be in need and

capable of becoming

independent with

minimum educational

and training assistance

Minimum 400

incapacity

${ }^{y} \sim$. In hours per

week (24 for
Family Credit

Also:

Disability Working

Allowance

Council Tax Benefit

General

General

Working families with children

Disabled people in work

Dis

Local tax relief
18 (if liable for

council tax)
Normally 18 , unless

parent or in hardship

No minimum age

ciable for

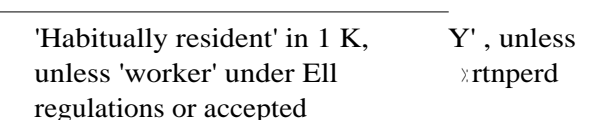

regulations or accepted

refugee. Other restrictions

relating to immigration status

No

No

partners of

unemployed

claimants)

Minimum of 16

hours per week

Minimum of 16

hours per week

Depends on being

currently or recently in

receipt of a specified

sickness or disability

benefit

(a)


Table 3.1: Main conditions of eligibility for income-related and nears-tested bendits in the OECD countries

\begin{tabular}{|c|c|c|c|c|c|c|c|c|}
\hline Country & General benefits & ategorical benefits & Target group & Minimum (max.) age & ResialerccelnatiorBality & Work tests & Working hours limit & Other \\
\hline \multirow[t]{5}{*}{ USA } & $\begin{array}{l}\text { Food Stamps } \\
\text { (nationa.1, regulated) } \\
\text { General Assistance } \\
\text { (State, regulated) }\end{array}$ & -- & Gene & $\begin{array}{l}\text { Normally IS (In } \\
\text { independent claims } \\
\text { Normally } 18\end{array}$ & $\begin{array}{l}\text { US citizens or lawfully } \\
\text { resident aliens } \\
\text { Depends on state }\end{array}$ & $\begin{array}{l}\text { Yes, unless } \\
\text { exempted } \\
\text { Yes, in some } \\
\text { states }\end{array}$ & & $\begin{array}{l}\text { Vaaries, in sonic states } \\
\text { only available to } \\
\text { disabled or 'chronically } \\
\text { nerdy' }\end{array}$ \\
\hline & & $\begin{array}{l}\text { Aid to Pan sties } \\
\text { with Dependent } \\
\text { Children }\end{array}$ & $\begin{array}{l}\text { Lone parents and two- } \\
\text { parent families with } \\
\text { unemployed main earner }\end{array}$ & No minimum age & $\begin{array}{l}\text { US citizens or lawful alien, } \\
\text { and resident of State in } \\
\text { which application made }\end{array}$ & $\begin{array}{l}\text { Yes, unless } \\
\text { exempt }\end{array}$ & $\begin{array}{l}\text { Maximum of } 100 \\
\text { hours per month }\end{array}$ & \\
\hline & & $\begin{array}{l}\text { Supplemental } \\
\text { Security Income }\end{array}$ & Aged, blind or disabled & $\begin{array}{l}65 \text {, unless blind or } \\
\text { disabled }\end{array}$ & $\begin{array}{l}\text { IJS citizen or lawfully } \\
\text { admitted alien, including } \\
\text { some whose status is being } \\
\text { decided }\end{array}$ & No & No & \\
\hline & & $\begin{array}{l}\text { Also: } \\
\text { Medicaid }\end{array}$ & $\begin{array}{l}\text { Medical costs for aged, } \\
\text { blind, disabled, families } \\
\text { and pregnant women }\end{array}$ & No age limits & & No & No & \\
\hline & & Veterans Pensions & $\begin{array}{l}\text { Disabled veterans and } \\
\text { their survivors }\end{array}$ & & Based on service in forces & No & No & $\begin{array}{l}\text { Pen nanent and total } \\
\text { disablement from non- } \\
\text { service connected } \\
\text { causes }\end{array}$ \\
\hline
\end{tabular}

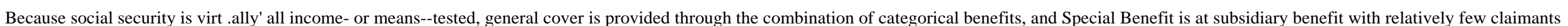


The first point that is evident from this table is that the policy of guaranteeing minimum incomes through one generalised, all-encompassing means-tested benefit is still fairly unusual. and is confined mainly to the Nordic states (the Norwegian Transitional Allowance is income-related. rather than means-tested. and is not regarded within Norway as part of social assistance). Canada has one broad national assistance framework. but the provincial autonomy of regulation and administration has the effect of creating a set of regional sub-systems of assistance. Under new Federal funding arrangements, to be introduced from 1996,7 , provincial autonomy will increase further. though with reduced central finance Volume Two, Chapter 5). Japan is a marginal case, since the assistance s there has a unified structure. but is divided into a number of functional elements. It could be argued that Austria and Switzerland also belong to the unit.ry since categorical schemes outside the main assistance benefits are 'i supplementary pensions and short-term unemployment assistance. The ; with some of the Scandinavian countries a high level of regional or local

The majority preference is still for separate coverage by popul -.egorv. here a number of approaches must be distinguished from one any >t Tier. One grou o. principally the southern European or Mediterranean countries. including $\mathrm{C}_{\mathrm{r}_{-}}$ Italy. Portugal. Spain and Turkey, organise limited minimum income protection principally in relation to specific groups, such as older or disabled people. families with children. or unemployed people (with unemployment assistance usually available only on a temporary basis). In some of these countries there is then a discretionary local assistance back-up. Althou ${ }^{\mathrm{g}} \mathrm{h}$ the scale of assistance provision in the USA is much greater than in any of these countries. it may he argued that the structure is not dissimilar. although welfare in the USA is identified particularly with lone-parent families.

Another group. including the UK and the other northern European countries. have one primary and inclusive national assistance benefit. together with a s a ving number of other categorical benefits which serve somewhat different funetin s. In the case of the UK. for example, Family Credit and Disability Working A.

have a specific function related to work incentives and low pay, an thus potentially reach further up the income scale than does Income Support. In-work benefits for families available in three Canadian provinces and in Ireland fulfil a similar function. The various categorical minima in Belgium and Luxembourg allow less restrictive rules to apply to groups such as the elderly. who might be seen as more 'deserving', and have different sources of finance. In the Netherl_ different schemes relate primarily to claimants' labour market status. mace and Ireland may be seen as fallin ${ }^{\mathrm{g}}$ in this group. althou ${ }^{\mathrm{g}} \mathrm{h}$ the extent of coverage derives more from the range of group-specific benefits rather than fr one overarching one. Finally. Australia and New Zealand have to be seen $\mathrm{t}$. gether as a separate case, where comprehensive coverage derives from their fully rem.' _r tested categorical benefit systems. None of these divisions. however, can be absolute. All countries have developed individual approaches based on n: history and policy traditions. and it is not possible to understand how v idely income protection is offered through different systems simply from the clu; ers of population groups named as the target beneficiaries. One way of - more closely at coverage is in terms of inclusion and exclusion of population, $\mathrm{c} 0 \sim$ ins by $\mathrm{a}^{\mathrm{g}} \mathrm{e}$ and by nationality or residence.

\subsection{Inclusion and exclusion}

\section{Minimum age thresholds}

Lookin $^{\mathrm{g}}$ first at the minimum age at which individual claims can be made for general-purpose assistance benefits, it is clear that the most common $\quad \sim \mathrm{d}$ is 18. Australia and New Zealand both differ in makin ${ }^{\mathrm{g}}$ special unemployrnec $\mathrm{t}$ or training benefits available from the age of 16, and Gc:'many- and Japan have no specific lower age limit. though the assumption is still parents would normally support children at least until they leave school. , act, most countries do not make assistance benefits. as such, available to students in higher education, and 
parents are normally regarded as responsible for them until the end of their courses. This policy, however, has to be seen in the light of wider educational policies and the availability of student grant aid --- topics which are not covered in any detail in this study.

France and Luxembourg stand out in restricting access to the Revenu Minimum d'inseretion (RMI) and the Rcreuu Minimum Garanti (RMG) to those aged at least 25 and 30 respectively (though minimum age thresholds are generally not applied to persons looking after dependent children). While in France some unemployed people under 25 may have access to insurance benefits on the basis of previous work. or to training courses and special employment schemes, it is clear that young people are relatively lacking in support through social assistance compared to those in most other countries with general schemes. The exclusion of people under 30 from eligibility in Luxembourg is regarded by national commentators as a major shortcoming of the RMG in principle. In practice, however, low unemployment and the availability of non-contributory access to temporary Unemployment Benefit for those under 21 completing full-time education. have tended to reduce the impact of this restriction.

In general, while comparison shows that restricting access to benefit in normal circumstances to those over 18 is not unusual, this policy also has to be seen alongside broader policies on youth training and employment, and on access to non-means-tested unemployment benefits. In a number of other countries, including Belgium, Denmark. Finland. Norway and Sweden. if young people are unemployed they may have access to non-contributory unemployment benefits, even if these are sometimes set at a level below that of social assistance. Others. such as Germany. the Netherlands and the UK, attempt to meet this need through special training or employment schemes. but with varying degrees of success.

\section{Residence and nationality conditions}

One of the other ways in which access to generalised social assistance benefits may be restricted is through nationality or residence conditions. The European Union's policy of free movement of workers in a single market makes this a live issue at present, particularly in the light of controversy over immigration from outside the Union. Table 3.1 gives an abbreviated account of nationality and residence conditions. which are often complex and closely inter-related with legislation on migration and citizenship.

More than half the countries in the study require some period of prior residence. in addition to citizenship of the relevant country or of another with which there is a reciprocal agreement. Within the European Union, the main exceptions are Belgium, Germany. Ireland, Italy, the Netherlands and Portugal. The most restrictive are. again, France and Luxembourg. where eligibility for the main assistance benefit is limited to those with ten years residence (or three years continuous, employed residence), and ten years residence out of the previous 20 years respectively. In Luxembourg, registration with a municipality is also required. Until 1992 Belgium required five years recent residence or ten years over a lifetime, but this was abolished as a result of a ruling in the European Court. Now only formal registration with a municipality is required, though this can still act as a further restriction - particularly for homeless people or others without fixed addresses. Denmark requires three years residence from EU citizens, while some regions in Spain impose their own varying prior residential conditions. In this context, the UK's recent decision to adopt an 'habitual residence' test for access to means-tested benefits is not especially anomalous, though it has been criticised for moving against the general trend of opening up access to benefits across the Union.

One of the groups most likely to face exclusion from or separate treatment in social assistance are recent migrants from outside the EU, especially refugees and asylum seekers. As the previous chapter showed, the economic vulnerability of refugees and other recent migrants means that in some countries they make up a substantial 
part of the social assistance caseload. There is clearly a tension between principles of inclusiveness, which are often expressed in policy statements, and anxieties about immigration, dependency and abuse of welfare benefits. In principle, the majority of countries take a broadly similar approach to this question, which gives people accepted as refugees, and accorded rights of residence, the same eligibility for assistance benefits as other citizens or legal residents. During the period where refugee or asylum status is being considered, the predominant pattern is for countries to make separate provision for emergency or reduced payments, either through special social security benefits, through non-governmental organisations such as the Red Cross, or through other private institutions. Frequently such benefits as are available carry no legal entitlement or rights of appeal. In Sweden. where local authorities have to meet most of the costs of providing assistance, central government provides extra funds to meet the expenses of help for refugees during the first three years of their residence in the country.

Countries with lengthy residential qualifying periods. such as France and Luxembourg, are in effect denying recent refugees and asylum-seekers access to assistance benefits. There has been some discussion in Luxembourg about amending regulations for this reason, but no proposals have yet been announced. Australia too has long qualifying periods for access to age pensions, and New Zealand for most benefits other than unemployment allowances, but since there is no insurance basis to their benefits, these restrictions should perhaps be seen partly as means of ensuring that recipients make a minimum tax contribution to the economy.

The economic and political pressures arising from both legal and illegal immigration have led some countries in the last few years to place further restrictions on benefit entitlement. Germany-, for example, which has accepted substantially higher numbers of both war refugees and economic migrants than most European countries since 1989, faces particular pressures both from reunification and from its geographical position on the borders of the Union. Since November 1993 asylum seekers have lost eligibility for general assistance and have to rely on special, reduced cash or in-kind payments. Debates in a number of other countries too have focused on apparent cases of fraud among immigrants, or special treatment accorded to them, though frequently the real situations turn out to be less dramatic than suggested by newspaper reports. Overall, the question of inclusion or exclusion within eligibility for social assistance benefits by age and by residential or nationality conditions is likely to remain a live issue in many of the countries in the study. This was highlighted by the Proposition passed in 1994 in the US State of California, which denies illegal migrants access to welfare and other social services.

Having established that an applicant is eligible to receive a particular benefit, the next part of the assessment process involves establishing entitlement. Under the principles outlined above, this invariably involves some test of resources.

\subsection{Conditions of entitlement}

The principle of means-testin ${ }^{\mathrm{g}}$ implies a series of administrative decisions about what constitutes the private resources of a benefit applicant, with whom these resources are assumed to be shared, who in a family or household should be expected to contribute personal resources to the upkeep of other individuals, and how much of the available private resources should be consumed before there is a call on public assistance. The decisions different countries take on these questions may reflect wider attitudes concerning the balance of responsibilities between the state and the individual/family.

Table 3.2 below lays out, in a schematic and abbreviated way, some of the main elements of the assessment process for entitlement to assistance benefits in the countries in our study. It relates primarily to the main, generalised assistance benefits where they exist. One difficulty involves making comparative sense of all 
the many and varying ways in which assets are treated and the forms and levels of income which are disregarded in the test of resources. As a way of classifying the treatment of earned income, countries are divided into four categories:

1. those applying no disregard

. those applying a minimal earnings disregard (up to 15 per cent of the standard single person rate)

3. those applying a medium disregard (between 16 and 40 per cent)

4, those applying a higher disregard (over 40 per cent).

It should be noted that these are approximate calculations. since disregards are often made up in different ways. apply only to earned or unearned income, or vary for different family types. Sometimes they are only available for limited periods or are reduced over time, and this is indicated in the table.

The treatment of assets is also very complex. In order to provide a basic comparison, it is presented in two parts. First countries are divided into two groups:

I. those which take all liquid assets into account, applying only a small disregard or none at all

?. those applying a higher disregard to capital.

Secondly, they are partitioned according to whether they tend to disregard the value of a private dwelling or might expect claimants to sell their homes before drawing on assistance.

There is also variety in the range of other income, including social security benefits_ which are counted or disregarded in the means test. As an indicator of approaches to one key area of policy of contemporary relevance in a number of countries, the table shows whether child maintenance is counted as income. Unless otherwise stated, the information applies to the year 1994. 
Table 3.2: Conditions of $\ll$, I.o the main assistance benefits

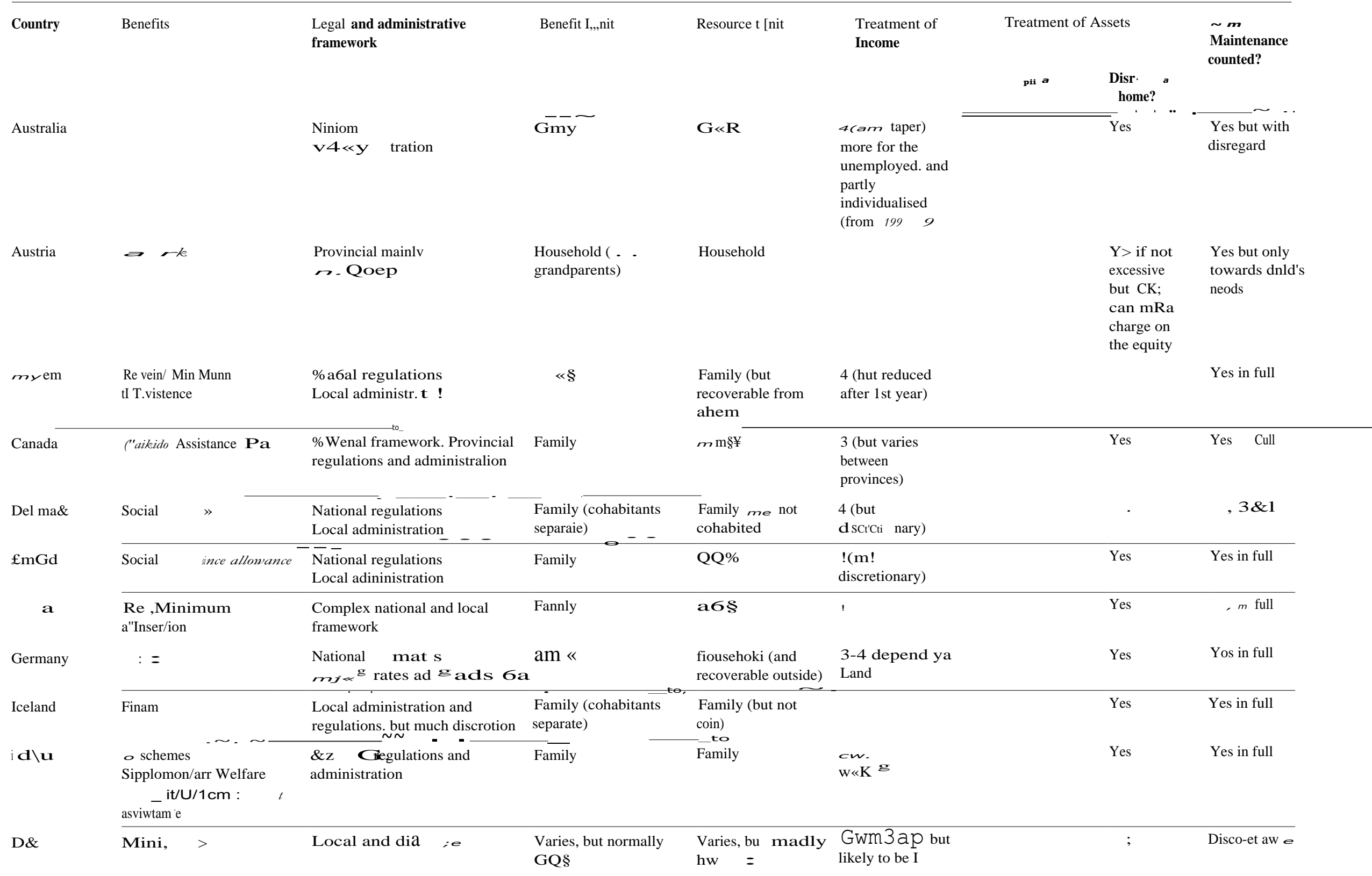




\begin{tabular}{|c|c|c|c|c|c|c|c|c|}
\hline \multirow[t]{2}{*}{ Country } & \multirow[t]{2}{*}{ Benefits } & \multirow{2}{*}{$\begin{array}{l}\text { Legal and administrative } \\
\text { framework }\end{array}$} & \multirow[t]{2}{*}{ Benefit Lnit } & \multirow[t]{2}{*}{ Resource Unit } & \multirow{2}{*}{$\begin{array}{l}\text { 'Freatment of } \\
\text { Income }\end{array}$} & \multicolumn{2}{|c|}{ Treatment of Assets } & \multirow{2}{*}{$\begin{array}{l}\text { Child } \\
\text { Maintenance } \\
\text { counted? }\end{array}$} \\
\hline & & & & & & Capital & $\begin{array}{l}\text { Disregard } \\
\text { home? }\end{array}$ & \\
\hline Japan & I,irehhood 4id & $\begin{array}{l}\text { National regulations } \\
\text { Local administrations }\end{array}$ & Household & Household & Ma & $\begin{array}{l}\text { I but } \\
\text { discretionary }\end{array}$ & $\begin{array}{l}\text { 'Yes if not } \\
\text { excessive }\end{array}$ & Yes in dill \\
\hline Luxembourg & $\begin{array}{l}\text { Rerenu Minimum Garanri } \\
\text { a. }\end{array}$ & $\begin{array}{l}\text { National regulations } \\
\text { Local administration }\end{array}$ & $\begin{array}{l}\text { Household } \\
\text { (will) exceptions) }\end{array}$ & Household & & 2 & & No \\
\hline Netherlands & $\begin{array}{l}\text { A/germane Bistimd and } \\
\text { Unemployment assistance } \\
\text { (RW\#W) }\end{array}$ & $\begin{array}{l}\text { National regulations } \\
\text { Local administration }\end{array}$ & $\mathrm{f}^{=}$amily $^{--}$ & Family & 2 & & $\begin{array}{l}\text { Ua h: it bow } \\
\text { sp cified } \\
\text { levels }\end{array}$ & No \\
\hline New Zealand & All & $\begin{array}{l}\text { National regulations and } \\
\text { administration }\end{array}$ & a $\quad \mathrm{Y}$ & aaaiiy' & 4 (with taped & & Yes & Yes in full \\
\hline Norway & $\begin{array}{l}\text { Social and Eeonomir } \\
\text { Assistance }\end{array}$ & $\begin{array}{l}\text { National framework } \\
\text { Local discretion }\end{array}$ & $\begin{array}{l}\text { Family (cohabitants } \\
\text { separate) }\end{array}$ & $\begin{array}{l}\text { Family (not } \\
\text { cohabitant) }\end{array}$ & $\begin{array}{l}2 \text { (mainly lone } \\
\text { parents) }\end{array}$ & 1 & $\begin{array}{l}\text { Yes (if } \\
\text { reasonable) }\end{array}$ & $\begin{array}{l}\text { Yes in full } \\
\text { (bait partial } \\
\text { disregard for } \\
\text { Transitional } \\
\text { Allowance) }\end{array}$ \\
\hline Portugal & $\begin{array}{l}\text { No general assistance } \\
\text { Ten social minimum schemes }\end{array}$ & National regulations & Family & Family & 1 & I & Yes & Yes in full \\
\hline Spain & $\begin{array}{l}\text { Ingram Ivlininu } \\
\text { de lnsercion }\end{array}$ & $\begin{array}{l}\text { National framework } \\
\text { Regional and local regulations } \\
\text { and discretion }\end{array}$ & $\begin{array}{l}\text { Family (cohabitan ts } \\
\text { separate) }\end{array}$ & Family & & 1 & Yes & Yes in full \\
\hline Sweden & Social Velftme Allowance & $\begin{array}{l}\text { National framework } \\
\text { Local discretion }\end{array}$ & Family & Family & I & 1 & $\begin{array}{l}\text { No if } \\
\text { alternal jive } \\
\text { housing can } \\
\text { be found }\end{array}$ & Yes in full \\
\hline sw Crldald & S0i:Mla F'airsarge & $\begin{array}{l}\text { Cantonal and municipal } \\
\mathrm{d} \text { iscration }\end{array}$ & Household & Household & $\begin{array}{l}\text { (discretionary) but } \\
\text { likely to be I }\end{array}$ & $\begin{array}{l}\text { (discretionary) } \\
\text { but likely to be } \\
\text { I }\end{array}$ & $\begin{array}{l}\text { Yeti if' } \\
\text { disabled but } \\
\text { discretionary }\end{array}$ & $\begin{array}{l}\text { Yes, taut } \\
\text { discretioiaary }\end{array}$ \\
\hline Turkey & $\begin{array}{l}\text { socfetl asidsta3 is and } \\
\text { solidarity }\end{array}$ & $\begin{array}{l}\text { National regulation } \\
\text { Local administration }\end{array}$ & Household & ouschold & l & 1 & $131 \mathrm{~K}$ & Yes, in full \\
\hline U & Income support & National ri;ulations & Family & $\mathrm{Fa} \quad \mathrm{Y}$ & $\begin{array}{l}2 \text { (but Family } \\
\text { Credit adds viper } \\
\text { effect) }\end{array}$ & 2 & Yes & $\begin{array}{l}\text { Yes in full } \\
\text { (bait partial } \\
\text { disregard for } \\
\text { Family Credit) }\end{array}$ \\
\hline USA & $\begin{array}{l}\text { I. AFDC' } \\
\text { 2. Fooditfamps } \\
\text { 3. GA }\end{array}$ & $\begin{array}{l}\text { State } \\
\text { FederallState } \\
\text { State/County }\end{array}$ & $\begin{array}{l}\text { Family } \\
\text { Household } \\
\text { Family }\end{array}$ & $\begin{array}{l}\text { Family } \\
\text { Household } \\
\text { Family }\end{array}$ & $\begin{array}{l}3 \\
4 \\
\text { varies by Stale }\end{array}$ & $\begin{array}{l}2 \\
2 \\
1--^{2} \text { depending }\end{array}$ & $\begin{array}{l}\text { Yes } \\
\text { Yes } \\
\text { Some can }\end{array}$ & $\begin{array}{l}\text { 1. Yes, but } \\
\text { with } \\
\text { disregard. }\end{array}$ \\
\hline & 4. SSI & federal/State & Individual & $\begin{array}{l}\text { Individual/ } \\
\text { family }\end{array}$ & 4 & $\begin{array}{l}\text { on State } \\
2\end{array}$ & $\begin{array}{l}\text { take a charge } \\
\text { on the equity } \\
\text { Yes }\end{array}$ & $\begin{array}{l}\text { Others:a } \\
\text { varies }\end{array}$ \\
\hline
\end{tabular}


The first point to note is that although many countries describe entitlement to benefit as 'individual' - that is, anyone can be assessed for benefit on the basis of their individual entitlement -- the actual unit for whom benefit is payable is still normally the claimant, plus spouse and dependent children in the case of nonsingle households, ie. the nuclear family. Only Austria, Luxembourg and Japan count other non-dependent adults in the household as part of the benefit unit (and thus include their needs in the calculation of benefit due). and in Luxembourg there are many exceptions to this rule.

The differences become more marked, however, when we look at the resource unit -that is, whose resources must be taken into account when applying the test of a claimant's means. Again, the majority of countries take into account only the resources of the claimant and their spouse if they have one. Generally the resources of dependent children are fully or partly exempted and if counted, this is normally only against amounts of benefit specifically payable in respect of children. In the UK. non-dependant deductions from housing costs imply an assumption of resource sharing within the wider household, but the expectation of intra-family support does not extend beyond this point (except for child maintenance). But there are a number of countries where expectations of family support extend further. In Austria, Germany. Switzerland and Japan, social assistance claimants may be expected to seek support from parents or grandparents, or in the case of older claimants from children and grandchildren - even, in Switzerland, potentially from other siblings before having recourse to public assistance. It is also of interest in this respect to note that in Switzerland there are no standardised means tests: benefits are assessed according to a detailed and individual investigation of both resources and needs, using standard household budgets as a template. In France, local Aide Sociale for older people (but not the RMI) is subject to a prior test of their (future) inheritors' means: monies paid can be reclaimed from these family members or by first claim on any assets left on death. In Belgium too, regulations were recently introduced which oblige local authorities to seek to recover assistance payments from parents or adult children of claimants. How these rules work in practice varies considerably and social welfare workers often have the discretion not to apply them, but what these countries have in common is a strong tradition of family responsibility and obligation, backed up in several countries by laws which specify duties of intrafamily maintenance which go beyond that of spouses or of parent and child.

At the other end of the spectrum is a small group of countries which do not place a maintenance or resource-sharing obligation even on spouses unless they are legally married. In Denmark and Norway. the resources of a man cohabiting with a lone mother are not taken into account as part of her resources for an assistance claim, although some expenses may be taken as shared. In Iceland and Spain too. cohabitees have to register as living together and sharing resources - a reversal of the more common situation - and in Iceland there is no duty of maintenance within cohabiting couples unless a child of the relationship is involved. Although in a few countries. including the Netherlands. there has been some debate about cohabitation in terms of the equivalence structure of payments. the subject seems to excite little of the kind of controversy which has periodically been a feature of the UK system. particularly in the case of lone parents (although the wider issue of assistance for lone parents has. of course, been highly controversial in the USA). It should be acknowledged, however, that the local and discretionary nature of many schemes potentially allows greater scrutiny of individuals' circumstances than may be apparent from a formal description of the systems, particularly in those countries where people have to register their place of residence. Policy concerns about lone parenthood and cohabitation are also likely to be influenced by numbers of lone parents claiming assistance. As we saw in Chapter Two. the percentage of lone parents in receipt of assistance payments varies considerable between countries.

Although no countries have gone as far as general individualisation of meanstested benefits, several, including the Netherlands and Ireland. have introduced the 
possibility of splitting payments between partners. In an interesting development, Australia has also introduced (from 1995) a partial individualisation of income support for the unemployed. The income test will be applied separately to each partner in a couple, and one spouse's earnings will only be be counted against the payments due to the other once the higher earner's income exceeds the cut-off point for entitlement. This was designed primarily as a work incentive measure, rather than as an explicit move towards independent incomes for women, and its impact has yet to be seen (Saunders. 1995).

The tie( truant resources

Turning to the question of the assessment of resources. we find a substantial group of countries which apply. or have the potential to apply, a relatively strict approach to the principle of subsidiarity. But they are an interesting and apparently paradoxical combination. Looking at the treatment of earnings. it is first of all the group of Latin and Mediterranean countries, along with Austria and Switzerland, which operate the most stringent tests and allow the least amounts of extra earnings to be retained. In the same group are the Nordic countries of Iceland. Sweden. and in effect Finland. since it is reported that discretionary disregards are not often applied. The same applies to Denmark, even though the guideline earnings disregard is rather higher. Ireland comes into this group for Supplementary Welfare Allowance, although disregards are available for Unemployment Assistance. The UK falls into a small group with relatively low disregards, including Norway and the Netherlands, though it should be born in mind that in the UK higher disregards apply to lone parents and that Family Credit in effect provides a tapered earnings disregard. It is not clear what levels of disregards normally apply in Japan.

Amongst the countries with higher levels of disregards, which includes the antipodean countries and the USA. these vary between client groups and some are available only for a specific period. It is noticeable, however, that Australia and New Zealand. the two countries with entirely selective benefit systems. have meanstests for most of their basic benefits which cut in at a considerably hi ${ }^{g}$ her level in proportion to benefit rates than do many of those in Europe. This effect is accentuated by the tapered withdrawal rates of benefit, which is unusual outside the English-speaking countries.

A similar picture emerges when we look at assets. In the group which takes more capital and assets into account. we first of all find Austria and Switzerland, with their highly discretionary and locally-based systems. They are also. as we saw, among those countries which pursue family financial obligations further than most. But this group also includes several of the Scandinavian countries, normally regarded as the most socially liberal. It was among these countries that we saw the principle of family financial obligation appearing weakest in relation to the resource unit for social assistance. Yet in Sweden, for example, it is re ${ }^{\mathrm{g}}$ arded as reasonable that, before having recourse to social assistance, people might well be expected to sell their house, and a car if they have one. unless there are no public transport alternatives for essential travel. A number of other countries, including the Netherlands. can insist on a home being sold if the value is above prescribed limits, while in Austria and some states of the USA (for General Assistance only). the authorities can take a charge on the equity of a claimants' house to recover benefit if the house is sold.

As regards child maintenance, it is interesting to note that while the political controversy over the Child Support Act in the UK has fuelled calls for maintenance to be at least partly disregarded for Income Support, the UK is within the OECD mainstream in counting it in full. Only the Netherlands and Luxembourg discount it entirely. and Australia and the USA (for AFDC) apply partial disregards. Norway applies a disregard for lone parents receiving Transitional Allowance, of up to 30 per cent of maintenance received above the minimum guaranteed level. Child benefit or family allowances are also normally 
counted in full, unless benefit rates are structured so as not to include child dependency additions.

How should we interpret these different patterns? First, it has to be emphasised that these elements of the benefit structure cannot be seen in isolation. We need to take into account other important features of the different systems. not least the value of benefits in relation to earnings, in order to see what apparently strict or more ${ }^{\mathrm{g}}$ enerous means tests actually mean in the context of different countries. Nevertheless. these findings do lead to some interesting speculations. For example. the apparent paradox of finding the toughest means tests in social-democratic Scandinavia. co-existing with a non-traditional view of family types and obligations (and, as we show later, relatively generous benefits but tough work tests), may not be so difficult to explain if we look at the broader social security systems and the role social assistance plays within them. In all the Nordic countries receipt of social assistance is seen as. in principle at least. a short-term, last resort measure. Normally $^{\circ}$. loss of earnings through unemployment or sickness would be dealt with through the social insurance system and the priority is to return to the labour market as soon as possible. Longer-term unemployment and family change may be putting some strain on this model, but at present social assistance recipients are still regarded as needing individualised, locally-based and discretionary help, only part of which may be in the form of cash. Earnings disregards may simply trap people on benefit and any high replacement rates which may result are seen as largely irrelevant, because the work tests and general work ethic, and the stigma attached to receipt of social assistance, should in most cases provide sufficient motivation. In this context. the greater individualisation of benefit entitlement. which stems from achievements made in emancipation and opportunities for women throughout society and results in an official view of cohabitation which differs from that in many other countries, is not inhibited by considerations of excessive cost.

In a system such as in Australia, on the other hand, where virtually all benefits are income and assets-tested (though at varying levels). stigma appears to be much less of a factor. Poverty alleviation and the encouragement of work effort then requires a more sophisticated range of instruments, including substantial assets disregards and earned-income 'free areas'. The UK falls somewhere between these two points, and while Income Support itself has only a very limited set of income disregards. it has been necessary to create Family Credit in order to provide some kind of incentive structure within an extensive, national means-tested benefit structure.

As regards approaches to the benefit and resources unit, it is perhaps most interesting to note the relative uniformity. With a number of exceptions where wider family obligations have retained a strong legal foundation, the nuclear family is the norm, in spite of some tentative moves towards forms of individualisation. Efforts to shift obligation back on to the wider family seem to be unsuccessful where it has been attempted. Belgian efforts. for example, to oblige local welfare centres to recover benefits from relatives have apparently been difficult to enforce (Lambrechts and Dehaes. 1986).

\subsection{Housing costs}

Housing costs are often a crucial element of the income requirements of lowincome households, and many countries either include all or part or the costs of accommodation within the assessment of needs for social assistance, or provide some form of separate income-related or means-tested housing allowance to people on low incomes. The relationship between housing needs and low income in a comparative perspective is. however, a matter of considerable complexity. To do justice to this area of assistance, a separate, comprehensive study would be needed and for present purposes only the key elements of housing assistance are examined here. Table 3.3 summarises the main forms of help with housing costs in the countries in the study. 
Table 3.3: Means-tested help with housing costs

\begin{tabular}{|c|c|c|c|c|}
\hline Country & Help available? & Form of housing assistance & Tenures covered & $\begin{array}{l}\text { Extent of housing } \\
\text { costs covered }\end{array}$ \\
\hline Australia & Yes & $\begin{array}{l}\text { Separate rent assistance for pensioners and beneficiaries in } \\
\text { private rented housing } \\
\text { Public sector tenants have rents subsidised through } \\
\text { Commonwealth State Housing Agreement } \\
\text { Other subsidies for home buyers }\end{array}$ & Renters only & $\begin{array}{l}\text { For private tenants, } \\
\text { up to } 75 \mathrm{~N} \text { of rent } \\
\text { over specified } \\
\text { thresholds } \\
\text { Public sector tenants } \\
\text { pay } 20-25 \% \text { of their } \\
\text { incomes in rent }\end{array}$ \\
\hline Austria & $\begin{array}{l}\text { Yes, but vGtries by } \\
\text { province }\end{array}$ & Payment as addition to social assistance & $\begin{array}{l}\text { Usually renters } \\
\text { only. } \\
\text { To prevent } \\
\text { homelessness } \\
\text { authorities can } \\
\text { take over } \\
\text { mortgage } \\
\text { payments }\end{array}$ & $\begin{array}{l}\text { Varies according to } \\
\text { province. Can meet } \\
\text { full costs or fixed } \\
\text { amounts }\end{array}$ \\
\hline Belgium & $\begin{array}{l}\text { Only on a local } \\
\text { discretionary basis }\end{array}$ & $\begin{array}{l}\text { Social assistance payments (RMG) are meant to cover } \\
\text { housin }{ }^{\mathrm{g}} \text { costs, No generalised housing benefit system } \\
\text { Subsidies mainly in 'bricks and mortar' }\end{array}$ & $\begin{array}{l}\text { At discretion of } \\
\text { local welfare } \\
\text { centre }\end{array}$ & \\
\hline Canada & $\begin{array}{l}\text { Yes, from Federal } \\
\text { and provincial } \\
\text { governments }\end{array}$ & $\begin{array}{l}\text { Shelter costs included in assistance payments, up to } \\
\text { maximum levels set by province } \\
\text { Social housing tenants pay rents according to their incomes }\end{array}$ & $\begin{array}{l}\text { Both private } \\
\text { renters and } \\
\text { owner-occupiers. } \\
\text { but some } \\
\text { provinces require } \\
\text { reimburse-ment } \\
\text { of increased } \\
\text { equity }\end{array}$ & $\begin{array}{l}\text { Actual housing costs } \\
\text { up to provincial } \\
\text { maximum }\end{array}$ \\
\hline Denmark & Yes & $\begin{array}{l}\text { Separate housing benefit scheme open to all those on low } \\
\text { incomes }\end{array}$ & $\begin{array}{l}\text { Both renters and } \\
\text { owner--occupiers }\end{array}$ & $\begin{array}{l}\text { Full costs over a } \\
\text { threshold graduated } \\
\text { according to } \\
\text { household } \\
\text { composition and size }\end{array}$ \\
\hline Finland & $\begin{array}{l}\text { Yes. but } \\
\text { discretionary }\end{array}$ & 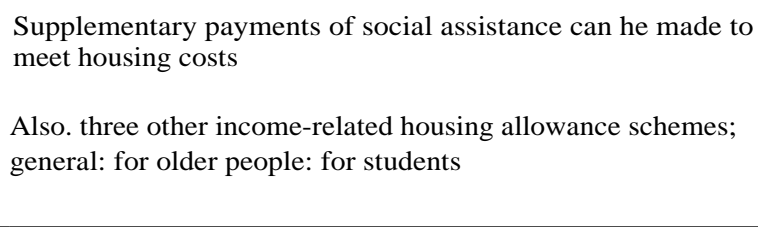 & $\begin{array}{l}\text { Both renters and } \\
\text { owner occupiers }\end{array}$ & $\begin{array}{l}\text { Up to } 80 \% \text { of } \\
\text { housing costs } \\
\text { covered. Social } \\
\text { assistance recipients } \\
\text { can receive help with } \\
\text { remaining } 20 \% \text {. }\end{array}$ \\
\hline France & Yes. & Separate housing benefit scheme & $\begin{array}{l}\text { Both renters and } \\
\text { owner occupiers }\end{array}$ & $\begin{array}{l}\text { Generally only part } \\
\text { of costs met. } \\
\text { depending on } \\
\text { household } \\
\text { composition and size }\end{array}$ \\
\hline Germany & Yes & $\begin{array}{l}\text { Supplementary payments to meet 'reasonable housing costs } \\
\text { can be made to social assistance recipients, at the discretion } \\
\text { of local authorities (but within guidelines) } \\
\text { Separate income-related housing benefit scheme (Wohngeld) } \\
\text { for low-income households }\end{array}$ & $\begin{array}{l}\text { Both renters and } \\
\text { owner-occupiers }\end{array}$ & $\begin{array}{l}\text { Social assistance } \\
\text { recipients can } \\
\text { receive full housi a } \\
\text { costs, including } \\
\text { heating } \\
\text { Payments of } \\
\text { mortgage interest } \\
\text { only. up to local } \\
\text { maxima }\end{array}$ \\
\hline Greece & $\begin{array}{l}\text { Yes, but only for } \\
\text { the elderly }\end{array}$ & $\begin{array}{l}\text { Income-related housing benefit scheme for older people } \\
\text { without full insurance-based pensions } \\
\text { Various other loans/subsidies and tax exemption schemes for } \\
\text { building homes }\end{array}$ & $\begin{array}{l}\text { Private tenants } \\
\text { only }\end{array}$ & $\begin{array}{l}\text { Rent paid direct to } \\
\text { landlords }\end{array}$ \\
\hline
\end{tabular}


Table 3.3: Means-tested help with housing costs -- come/. )

\begin{tabular}{lll}
\hline Country & Help available? & Form of housing assistance \\
\hline Iceland & Yes & $\begin{array}{l}\text { Housing policy tends to favour owner-occupation. Means- } \\
\text { tested loans are available for up to } 90 \% \text { of cost }\end{array}$
\end{tabular}

Both renters and owner-occupiers
Tenures covered
Financial Assistance includes component for rent. but since January 1995 local authorities have the power to operate separate housing allowance schemes
Extent of housing costs covered

For house buyers, interest rate for loans set according to income. household size and family type

For renters on social assistance, only about a third of average rents likely to be met within Financial Assistance

\begin{tabular}{|c|c|c|}
\hline Ireland & Yes & $\begin{array}{l}\text { Rent and mortgage supplements available through } \\
\text { Supplementary Welfare Allowance }\end{array}$ \\
\hline
\end{tabular}

Local authority tenants have rents related to their incomes,aecording to rules set by each local authority
Private and housing association tenants and owner-occupiers

Public tenants
Mortgage assistance limited to interest only Otherwise full costs week met minus £IR 5 per

\begin{tabular}{lll}
\hline Italy & $\begin{array}{l}\text { No housing } \\
\text { allowance scheme }\end{array}$ & $\begin{array}{l}\text { Small number of public housing places for those on low } \\
\text { incomes }\end{array}$ \\
\hline
\end{tabular}

Japan Yes Housing Aid

Renters and owner occupiers

Can cover housin $\mathrm{g}$ deposits, rent and necessary repair costs. up to locally determined maxima

\begin{tabular}{lll}
\hline Luxembourg & Yes & Rent allowances payable only as part of Revenu Minimum Renters only \\
Garanti
\end{tabular}

Difference between gross rent and $10 \%$ of RMG payment to household, up to specified maximum

The Netherlands Y

Social assistance payments meant to cover housing. but

Renters and Cost met above separate housing benefit available to meet particularly high costs. Administered separately from social assistance

owner-occupiers in flats or houses specified level and

Where costs exceed specified ceiling, temporary supplement (single room below set limit available through social assistance. Recipient supposed to tenants not seek cheaper dwelling

\begin{tabular}{|c|c|c|c|c|}
\hline New Zealand & Yes & Accommodation Supplement & $\begin{array}{l}\text { Renters, boarders } \\
\text { and owner- } \\
\text { occupiers }\end{array}$ & $\begin{array}{l}\text { Supplement meets } 65 \\
\text { per cent of costs over } \\
\text { threshold ( } 25 \text { of } \\
\text { 'base benefit rate' for } \\
\text { renters and } 30 \% \text { for } \\
\text { home owners), up to } \\
\text { specified regional } \\
\text { limits } \\
\text { For owner-occupiers, } \\
\text { both interest and } \\
\text { capital payable }\end{array}$ \\
\hline Norway & Yes & Payable as supplement to social assistance payments & $\begin{array}{l}\text { Renters and } \\
\text { owner-occupiers }\end{array}$ & $\begin{array}{l}\text { Full rent and both } \\
\text { interest and capital } \\
\text { payments met if } \\
\text { 'reasonable'. Capital } \\
\text { element may be } \\
\text { limited }\end{array}$ \\
\hline Portugal & Yes & $\begin{array}{l}\text { Means-tested housing allowance administered by Ministry } \\
\text { of Public Works. Recipients must have suffered } 30 \% \\
\text { reduction in monthly income or have income at level of the } \\
\text { non-contributory social pension }\end{array}$ & Renters only & $\begin{array}{l}\text { Fixed amounts, } \\
\text { limited to } 12 \text { months } \\
\text { duration }\end{array}$ \\
\hline
\end{tabular}


Table 3.3_ Means-tested help with housing costs \%enured

\begin{tabular}{|c|c|c|c|c|}
\hline Country & Help available? & Form of housing assistance & Tenures covered & $\begin{array}{l}\text { kxtent of housing } \\
\text { costs covered }\end{array}$ \\
\hline Spain & $\begin{array}{l}\text { No general } \\
\text { scheme }\end{array}$ & & & \\
\hline Sweden & Yes & $\begin{array}{l}\text { Social assistance recipients can have housing paid as } \\
\text { supplement to assistance standard if 'reasonable' } \\
\text { Also general, income-related housing benefit scheme } \\
\text { administered by regional social insurance office } \\
\text { Pensioners can also receive income-related } \mathrm{mu}^{\mathrm{g}} \\
\text { housing supplement }\end{array}$ & $\begin{array}{l}\text { Renters and } \\
\text { owner-occupiers }\end{array}$ & $\begin{array}{l}\text { For assistance } \\
\text { recipients_full costs } \\
\text { met if reasonable. } \\
\text { Interest payments } \\
\text { only on mortgages }\end{array}$ \\
\hline Switzerland & Yes & $\begin{array}{l}\text { Assistance payments can include housing costs } \\
\text { Help also through social housin }{ }^{g} \text { aimed at low-income } \\
\text { groups }\end{array}$ & $\begin{array}{l}\text { Renters and } \\
\text { owner-occupiers }\end{array}$ & Discretionar \\
\hline
\end{tabular}

\begin{tabular}{ll}
\hline Turkey & $\begin{array}{l}\text { No housin } \\
\text { assistance scheme }\end{array}$
\end{tabular}

\begin{tabular}{ll}
\hline United & Housing Benefit scheme open to all tenants. Administered \\
Kingdom & by local authorities. Rules of eligibility. entitlement and \\
& means test aligned with Income Support £except for double \\
& capital limit)
\end{tabular}

$\begin{array}{ll}\text { Private and } & \text { Income Support } \\ \text { public tenants } & \text { recipients can have } \\ & \text { full rent met if } \\ & \text { reasonable. For } \\ & \text { those with incomes } \\ & \text { above this level, } \\ & \text { maximum benefit is } \\ & \text { reduced by } 65 \mathrm{p} \text { for } \\ & \text { each } £ 1 \text { of extra } \\ & \text { income }\end{array}$
Owner-occupiers can receive help with mortgage interest Owner-occupiers payments as supplement to Income Support (but not Family Credit).

$\begin{array}{llll}\text { USA } & \begin{array}{l}\text { No national } \\ \text { housing assistance }\end{array} & \begin{array}{l}\text { Various state and local schemes for rental and mortga } \\ \text { assistance, based on reducing housing payments to fixed } \\ \text { percentage of income. Rental schemes mainly through low- }\end{array} & \begin{array}{l}\text { Renters and } \\ \text { owner-occupiers }\end{array} \\ & \text { cost housing projects or vouchers } & \begin{array}{l}\text { Provision of } \\ \text { assistance } \\ \text { geographically } \\ \text { uneven and limited }\end{array}\end{array}$

Also. Low-Income Energy Assistance Pro ${ }^{g}$ ram (LIHFAP)

The table shows that only three countries (Italy, Spain and Turkey) do not have either a generalised scheme for housing assistance or an element within social assistance payments to meet housing costs. However, there are also differences between countries in whether the housing clement of social assistance is paid as a specific supplement or is meant to be met out of the standard assistance payment. Belgium and the Netherlands are the two main examples of the latter approach. although where claimants face particularly high housing costs any extra help available is purely discretionary in Belgium, whereas there access to a regulated Housin $^{\mathrm{g}}$ Benefit scheme in the Netherlands. As with other elements of assistance in Switzerland, help with housing costs is largely discretionary and varies according to the canton or municipality.

Countries which operate general housing benefit schemes open to all those on low incomes_- as well as assistance recipients. include Denmark. France, Germany. Sweden and the UK. Portugal also has a time-Iimited general scheme, while Finland and Greece both have limited schemes for certain categories of people. 
One important aspect of housing support is whether it can cover mortgage payments for owner-occupiers as well as rents. The picture is somewhat more complicated than it appears from Table 3.3, because there are often other forms of subsidy outside benefit systems for both tenants and owner-occupiers, including public house building. tax reliefs, rent controls and special loan arrangements. However, it is clear that the predominant pattern among the OECD countries which have housing allowances is for means-tested help to be available directly through social assistance to house buyers and tenants alike. The exceptions are Australia, Austria (normally). Greece, Luxembourg and Portugal. Within this broad pattern. however. there are differences as to whether support is available to owner occupiers in the same way as for tenants. Some countries. for example. meet only the interest element of mortgage payments. whereas others meet capital repayments too. As we saw earlier. some countries, including Austria and some states of the USA. for General Assistance, have the power to take a charge on the equity of claimants' housing property. The U.K has recently introduced limits on the level of mortgage for which interest payments can be made through Income Support. There have also been calls in the UK for a form of housing benefit to be extended to owner-occupiers because of a perceived imbalance in the support available to Income Support recipients compared with others on low incomes.

The costs which can be covered often include heating and other services, as well as rent or mortgage interest, but what is more difficult to judge from the information gathered for this study is how far in practice assistance recipients' full housing costs are met in different circumstances and how much has to be met out of the main benefit payments. The model family approach taken in Chapter Six provides some further information on this question for a number of family types living in rented accommodation.

\subsection{Meeting urgent or exceptional needs}

Methods of meeting urgent or exceptional needs falling outside those expected to be met from normal benefit payments have been a subject of some controversy in the UK for many years (Craig, 1993). Some similar debates have taken place in the USA. where the welfare rights movement has used discretionary exceptional needs as an organising technique to expand payments. Yet in looking at other countries it is difficult to escape the conclusion that this is to a large extent a peculiarly Anglosaxon controversy, linked particularly to the historical development of assistance schemes which provide for the livelihood of substantial proportions of the population, and for some on a long-term basis. Although most countries have some arrangements for meeting exceptional needs, these are frequently discretionary and highly individualised, and generally administered at the local level. Rarely do they appear to provoke intense debate. and it is often difficult to obtain either statistical information on claims and expenditure or more qualitative details about guidelines or practices, since the data are often not collected separately at a national level.

An earlier report gathered some information on one-off needs in 15 countries \{Bradshaw et $a L, 1993 \mathrm{~b}$ ), and a further brief comparative survey was undertaken by Craig (1993) in his review of alternative policy approaches to the UK social fund. Table 3.4 summarises methods of dealing with one-off needs. drawing on both these studies and new data obtained for the current study. More detail, including. for some countries- expenditure on one-off payments, can be found in the country reports in Volume Two. 


\begin{tabular}{|c|c|c|c|c|}
\hline Country & $\begin{array}{l}\text { Arrangements for meeting } \\
\text { special or one-off needs }\end{array}$ & $\begin{array}{l}\text { Regulated or } \\
\text { discretionary? }\end{array}$ & Forut of payment & Ibfaira types of need met \\
\hline \multirow[t]{3}{*}{ Australia } & Special Benefit & $\begin{array}{l}\text { Regulated. Capital linnt of } \\
\text { AS5,000 }\end{array}$ & Grant & $\begin{array}{l}\mathrm{P}_{\text {eople in severe financial need and not entitled to any }} \\
\text { other benefits (received by only around one per cent } \\
\text { of all assistance recipients) }\end{array}$ \\
\hline & $\begin{array}{l}\text { Lump-sum work'study grants } \\
\text { available }\end{array}$ & Regulated & & $\begin{array}{l}\text { Long-terra unemployed starting Cull-time work or } \\
\text { study ( } \$ 50-200 \text { available once only with } 12 \text { months }\end{array}$ \\
\hline & Disaster Relief & $\begin{array}{l}\text { Regulated, not only for } \\
\text { assistance recipients }\end{array}$ & & $\begin{array}{l}\text { One-off payments equivalent to two weeks benefit } \\
\text { plus family payments and rent assistance }\end{array}$ \\
\hline \multirow[t]{2}{*}{ Austria } & $\begin{array}{l}\text { Range of special payments, } \\
\text { additions to normal benefit, } \\
\text { plus 'support to meet special } \\
\text { contingencies in life' }\end{array}$ & $\begin{array}{l}\text { Mainly discretionary. } \\
\text { Dietaare, furniture and } \\
\text { clothing needs bring } \\
\text { notional entitlement }\end{array}$ & $\begin{array}{l}\text { Both, but loans more } \\
\text { corrmion. Repayment by } \\
\text { individual agreement }\end{array}$ & $\begin{array}{l}\text { Needs arising from unexpected events. Special diets, } \\
\text { essential furniture and clothing_essential travel, such } \\
\text { as to funerals }\end{array}$ \\
\hline & & $\begin{array}{l}\text { Discretionary payments } \\
\text { must not exceed fixed local } \\
\text { budgets }\end{array}$ & & Loans also available for business start-up \\
\hline Belgium & $\begin{array}{l}\text { Assumption that most special } \\
\text { needs can be met within regular } \\
\text { Minimex payments, but } \\
\text { Supplementary Assistance } \\
\text { available. }\end{array}$ & $\begin{array}{l}\text { Discretionary, but. subject } \\
\text { to appeal }\end{array}$ & $\begin{array}{l}\text { Normally grants, but } \\
\text { interest free loans can be } \\
\text { given at discretion of } \\
\text { local welfare centre. } \\
\text { Receipt of money advice } \\
\text { may be condition of } \\
\text { payment: }\end{array}$ & $\begin{array}{l}\text { In January } 198912 \text { per cent of assistance recipients } \\
\text { also received supplementary payments, averaging BF } \\
9,504)--10,500 \text {. Most common items were fuel costs } \\
\text { (around a third of all payments), rent arrears and } \\
\text { deposits, special health costs, winter support, school } \\
\text { trips, telephone bills and connections and other } \\
\text { arrears }\end{array}$ \\
\hline \multirow[t]{2}{*}{ Canada } & $\begin{array}{l}\text { Needs test for assistance } \\
\text { includes special and emergency } \\
\text { needs }\end{array}$ & $\begin{array}{l}{ }^{\mathrm{P}} \text { rovincial discretion, but } \\
\text { some have local regulations }\end{array}$ & $\begin{array}{l}\text { Crisis payments can he } \\
\text { made is loans. } \\
\text { Otherwise grants }\end{array}$ & $\begin{array}{l}\text { Wide variation between province:. Typical needs } \\
\text { met include home repairs, travel expenses, moving } \\
\text { expenses, baby supplies. In Ontario in } 1990 \text { average } \\
\text { expenditure by municipalities on special items varied } \\
\text { from `h49 ... \$532 per recipient }\end{array}$ \\
\hline & & & & $\begin{array}{l}\text { Also, in some states, children's winter clothing } \\
\text { allowances, back-to-school, and employment start-up } \\
\text { allowances available }\end{array}$ \\
\hline Denmark & $\begin{array}{l}\text { Longstanding element of social } \\
\text { assistance }\end{array}$ & $\begin{array}{l}\text { Discretionary. No fixed } \\
\text { budgets }\end{array}$ & Grants & $\begin{array}{l}\text { Items include medical and dental treatment, education } \\
\text { costs, removal expenses. No fixed amounts for } \\
\text { specific needs }\end{array}$ \\
\hline
\end{tabular}

In 1992 approximately 84,000 people received one- 


\begin{tabular}{|c|c|c|c|c|}
\hline Country & $\begin{array}{l}\text { Arrangements for meeting } \\
\text { special or one-off needs }\end{array}$ & $\begin{array}{l}\text { Regulated or } \\
\text { discretionary? }\end{array}$ & Form of payment & Main types of need met \\
\hline \multirow[t]{2}{*}{ Finland } & $\begin{array}{l}\text { Supplementary allowance } \\
\text { payable in addition to regular }\end{array}$ & $\begin{array}{l}\text { Discretionary. No fixed } \\
\text { budgets }\end{array}$ & Grants & $\begin{array}{l}\text { Includes housing costs, medical and funeral costs and } \\
\text { 'other necessary expenses' }\end{array}$ \\
\hline & $\begin{array}{l}\text { assistance } \\
\text { 'Preventative' allowance }\end{array}$ & & & $\begin{array}{l}\text { Grants to avoid long-term dependency, such as to } \\
\text { families in crisis, for training or rehabilita€tion, } \\
\text { mortgage capital repayments etc. } \\
\text { Expenditure on preventative payments in } 1992 \text { was } \\
\text { ELM } 17.1 \text { million }\end{array}$ \\
\hline France & $\begin{array}{l}\text { Aide Social(' and Action } \\
\text { Sneicrie at state, regional and } \\
\text { local level can all include } \\
\text { special and one-off payments }\end{array}$ & Largely discretionary & Both grants and loans & Medical costs. heating costs, other debts \\
\hline \multirow[t]{2}{*}{ Germany } & $\begin{array}{l}\text { Both general assistance and } \\
\text { 'help in special circumstances' } \\
\text { can include one-off or special } \\
\text { payments }\end{array}$ & $\begin{array}{l}\text { Depends on type of need, } \\
\text { Essential furniture, clothing } \\
\text { and household needs carry } \\
\text { legal entitlement, but } \\
\text { authorities can use } \\
\text { discretion to decide how } \\
\text { needs should be met }\end{array}$ & $\begin{array}{l}\text { Both grants and loans, } \\
\text { also in-kind. } \\
\text { Payments for debts such } \\
\text { as heating arrears usually } \\
\text { recoverable }\end{array}$ & $\begin{array}{l}\text { General assistance can include lump-sum payments } \\
\text { for clothing. furniture, beds, cookers, refrigerators, } \\
\text { arrears. Also urgent or emergency cash payments. } \\
\text { Average one-off payments tend to he around } 20 \mathrm{~L} \text { of } \\
\text { applicable scale rate }\end{array}$ \\
\hline & & & $\begin{array}{l}\text { Some types of special } \\
\text { circumstances payments } \\
\text { are recoverable, such as } \\
\text { help with self-employed } \\
\text { business start-up }\end{array}$ & \\
\hline Greece & Special state assistance & $\begin{array}{l}\text { Subject to national } \\
\text { regulations, but payable at }\end{array}$ & Grants & $\begin{array}{l}\text { Available in cases of natural disaster or for } \\
\text { individuals (and especially large tau:ities) in financi } 1\end{array}$ \\
\hline & & discretion of Prefectures. & & emergency. Payments from DR t lif!'s to maximum \\
\hline & & $\begin{array}{l}\text { Subject to detailed } \\
\text { household means test }\end{array}$ & & of 200.000 in one year \\
\hline Iceland & $\begin{array}{l}\text { Payable as addition to I"iana.ncial } \\
\text { Assistance }\end{array}$ & $\begin{array}{l}\text { Discretionary. Only } \\
\text { available to assistance } \\
\text { recipients and payments }\end{array}$ & $\begin{array}{l}\text { Both grants and loans can } \\
\text { be made, but loans } \\
\text { uncommon }\end{array}$ & $\begin{array}{l}\text { if o meet emergencies such as loss of home or } \\
\text { possessions following a natural disaster, or for } \\
\text { special requirements such as funeral or removal costs }\end{array}$ \\
\hline
\end{tabular}




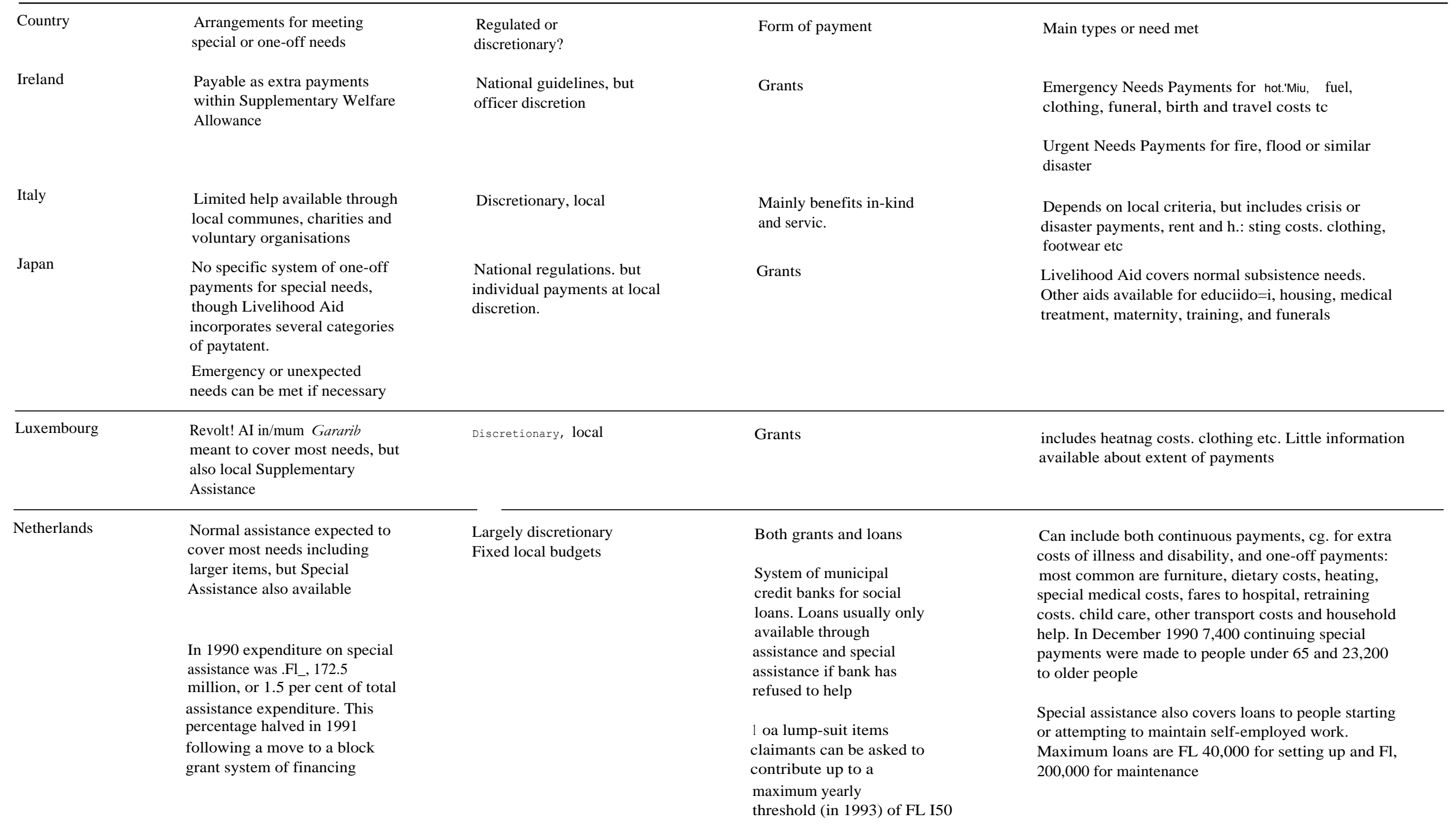


Th'rble $3 F_{-} \quad$ Methods of meetin ${ }^{\mathrm{g}}$ urgent and one--off needs I contd.)

\section{Country \\ Arrangements for meeting \\ special or one-off needs}

New Zealand

Special Needs Grant

t,-Eenditure on SNG in 1993/4 was NZ\$67.9 million

Special Benefit.
Regulated or

discretionary?

Regulated, but with discretionary elements
Form of payment

Grants and leans. Food

payments non-

recoverable, clothing

payments recoverable

Applicants may be

referred first to local

$l^{\text {'oodbank and for }}$

budgetary advice

\section{Main types of need met}

Need must have arisen in an emergency. Items

covered include food, clothing, housing deposits, fuel costs, essential appliances, school costs and unitorans, ear safety restraints for children, medical expenses and essential travel

Maximum amount NZ)200. Only one grant can be made for similar needs at one time and aggregate maximum for specific items in one year, eg. NZS150 for food for a single person.

To meet situation of continuing income deficiency relating to special cost

\begin{tabular}{ll} 
Norway & $\begin{array}{l}\text { Payments available under } \\
\text { section of assistance law } \\
\text { covering help to overcome or } \\
\text { adapt to 'a difficult life, situation" }\end{array}$ \\
\hline Portugal & $\begin{array}{l}\text { [Long tradition of discretionary } \\
\text { one-off payments through } \\
\text { local authorities and charities }\end{array}$ \\
\hline Spain & $\begin{array}{l}\text { One-off and emergency } \\
\text { payments available through } \\
\text { local authorities and charities }\end{array}$ \\
& $\begin{array}{l}\text { Payments are funded by central } \\
\text { government, local taxes and } \\
\text { lotteries }\end{array}$ \\
Sweden & $\begin{array}{l}\text { Most costs expected to be met } \\
\text { from normal assistance } \\
\text { payments. but one-off extra } \\
\text { payments available }\end{array}$ \\
Switzerland & $\begin{array}{l}\text { No special arrangements for } \\
\text { one-off payments. All } \\
\text { assistance is discretionary and } \\
\text { can be one-off or continuing }\end{array}$
\end{tabular}

Mainly discretionary ${ }^{\circ}$. but legal entitlement to birth grants

Discretionary

1)iscretionary and benefits in-kind

Discretionary

Discretionary
Casually grants or benefits

in kind. Less commonly

loans can he made

Expensive dental treatment, special tsrecliciaaes, winter clothing.

Receiving counselling may be condition of award

Depends on local criteria.. May be linked to receipt of counselling

No national data, but in Barcelona in 1991 Caritas (on behalf of the municipality) distributed payments for housing and fuel costs (about a thine of the total). food, children's meals and school costs, needs of older people, health and disability costs etc.

In 1991 loans from Caritas for housing costs of the elderly totalled 35 million pesetas

Typical payments include funeral costs, dental and eye treatment.

Grants. Can be condition that claimant undergoes debt counselling

Grants, but all assistance payments are notionally repayable

\section{Cost of loan repayments not covered}

Part of general discretionary assistance, which can be one-off or continuous depending on individuals assessed needs 


\begin{tabular}{ll}
\hline Country & $\begin{array}{l}\text { Arrangements for meeting } \\
\text { special or one-off needs }\end{array}$ \\
\cline { 2 - 3 } Turkey & $\begin{array}{l}\text { Lump-stint payments for } \\
\text { emergency needs under Social } \\
\text { Assistance and Solidarity } \\
\text { Scheme. }\end{array}$ \\
Social Fund \\
Net expenditure in 1993/4 \\
\\
$\begin{array}{l}\text { (after repayment of loans) was } \\
\text {.228 million, or about } 1.4 \% \text { of } \\
\text { Income Support spending and } \\
0.3 \% \text { of total social security } \\
\text { expenditure }\end{array}$
\end{tabular}

USA

\begin{tabular}{|c|c|}
\hline $\begin{array}{l}\text { Regulated or } \\
\text { discretionary? }\end{array}$ & Form of payment \\
\hline $\begin{array}{l}\text { Discretionary and budget- } \\
\text { limited }\end{array}$ & Mainly giants \\
\hline $\begin{array}{l}\text { 1. Maternity, funeral and } \\
\text { cold weather payments } \\
\text { regulated and with legal } \\
\text { entitlement and right of } \\
\text { appeal }\end{array}$ & $\begin{array}{l}\text { Maternity, cold weather } \\
\text { payments and community } \\
\text { care g ants all non- } \\
\text { recoverable. Funeral } \\
\text { payments recoverable } \\
\text { from estate }\end{array}$ \\
\hline $\begin{array}{l}\text { 2. Other payments } \\
\text { discretionary within. } \\
\text { national guidelines, with } \\
\text { right of review }\end{array}$ & $\begin{array}{l}\text { Other payments made as } \\
\text { loans. Repayable at } \\
\text { varying percentage of } \\
\text { income support rates }\end{array}$ \\
\hline
\end{tabular}

\author{
Federal guidelines, but \\ optional and state- \\ Emergency Assistance to \\ Needy Families with Children -- \\ linked to AFDC \\ administered (currently in \\ 37 states)
}

SSI emergency need payments

Food Stamps.....urgent payments

\section{General Assistance}

Emergency Assistance

Programmes (some states only)
Federally regulated

State, optional and discretionary

\section{Main types of need net}

Items likely to be covered include health costs. funeral expenses, clothing. food. heating and schoo expenses

$£ 10$ (7 for maternity needs.

Variable amount for funeral costs.

Cold weather payments for weekly periods of exceptional cold in an area

\section{Crisis Loans: for emergencie}

Budgeting Loans: for lump-sum items such as essential furniture and household equipment

Community C'an'e Grants: mainly to help people to move out of residential care or to stay in the community, for travel expenses, or to relieve exceptional pressure on families.

Payments (except crisis loans) only for people receiving other specified means-tested benefits
Grants, payments in kind and services

Grants, mainly repayable from future benefit

Grants
To prevent destitution. Includes medical payments. vouchers, cash, counselling and services. Payments cannot exceed 30 days in any 12 months. Average US monthly caseload in 1992 was 52,906, with average family payments of $\mathrm{x} 421$.

Interim cash payment while SSI claims pending. or vouchers to meet urgent needs.

Household in immediate need and with little or no cash assets should be given expedited service and provided with foodstamps within five days of application.

One time only cash assistance to nerdy f-" :_-pi ${ }^{\text {g: }}$ in ti mes of crisis. Examples include $\mathrm{I}=$ :tnie $\mathrm{rEe}<$; _roycd by fire or natural disaster, utilities cut off 1(-tr nonpayment of bills, family has run out of food or fads eviction. 
There are a number of points which emerge from an examination of this table and from the more detailed information in Volume Two. First, most countries do have some form of provision for exceptional or urgent needs falling outside what is expected to be met from re ${ }^{\mathrm{g}}$ ular payments. The countries without substantial traditions of special one-off payments include Australia (except for disasters) and Japan (although the different categories of Livelihood Aid can be seen as performing some of the same functions).

The predominant pattern, however. is for payments of this kind to be made at the discretion of local social welfare staff. While in some countries they will be working within national or local guidelines, it is rare for there to be detailed specification of allowable items of the kind which existed in the former UK single payments scheme. A few countries. including Austria, Canada. Germany. Norway, UK and the LISA, have regulated entitlement to certain limited items. while mainly providing discretionary support, though there is no obvious pattern in the range of needs falling into the former rather than the latter category. The Netherlands is one of the countries with the most developed range of special provision for exceptional needs, both through Special Assistance (BB), other municipal schemes and through its social loans sector, but again this is largely discretionary and provision varies substantially across the country. The local municipal provision in particular has been the subject of criticism for its variability and inefficiency (van Oorschot and Smolenaars. 1(993). Germany too has a wide range of special forms of assistance provision through the branch of Soialhilfe dealing with 'help in special circumstances'. but this includes long-term support for older people in residential care and several other types of continuing assistance in addition to oneoff payments.

In spite of variation in the methods of delivery of exceptional payments, the kinds of expenditure covered are not dissimilar across the countries studied. although the extent of overlap between them varies. Broadly speaking, most countries with oneoff cash assistance schemes provide for some or all of the following needs: large items of household expenditure such as essential furniture and appliances; funeral and birth expenses; travel costs in some exceptional circumstances; heating costs: special dietary costs; medical and dental costs over and above those covered by national health schemes or insurance; back-to-work costs (including child-care costs in some countries): special costs associated with children, including school clothing and other educational costs; high housing costs and arrears; other clothing and footwear needs; and unpredictable crises. It is not easy to discern which are the most commonly awarded items overall or which consume the greatest proportion of expenditure, since few countries collect or publish this information in any detail. Items like essential furniture, cookers and children's clothing are likely to be difficult for people on assistance to afford in most countries, so it is not surprising to find them high on the list of common items. Medical costs were also mentioned in a number of countries, but the kind of items covered depends on the particular health insurance or national health system in individual countries.

One-off or emergency payments in most countries are made mainly as nonrecoverable grants rather than loans, though there are some important exceptions. The bulk of UK exceptional payments are now made as loans, and recoverable payments and social loans are important in the Netherlands. Some payments in Germany and Spain can be in the form of loans. and payments for food under New Zealand's Special Needs Grant are also recoverable. In theory, any assistance payments are recoverable in Austria and Switzerland, though it is not clear how often this happens. Although one-off payments made in the Scandinavian countries are generally not expected to be repaid, the discretionary and individual nature of arrangements in local municipalities may allow for variations in practice. Where payments can be made through a mixture of grants and loans, a distinction also often appears to be made between items like arrears payments, which are more likely to be recoverable, and essential purchases or medical costs, which are more likely to be met through non-repayable grants. A number of countries, including Belgium, Portugal, Norway and the USA. explicitly associate the award of some 
payments with receiving money advice or counselling, but it is likely that this also commonly takes place in other countries. such as the other Nordic states, with a strong social work element in their social assistance.

The role of non-governmental organisations in debates around poverty and social assistance is discussed in a later chapter, but it is clear that in certain countries, mainly those of southern Europe and the Mediterranean but including, more recently, New Zealand, exceptional needs of low-income families are at least partly met by charities, churches and other voluntary organisations. The international organisation Caritas is particularly involved in this work in the Catholic countries of Italy. Spain, and Portugal. and often works with regional or local authorities in the provision of both services and cash help. Although charities and voluntary organisations play a role in this field in northern Europe too, their work is secondary to that performed by agencies of the state.

It is difficult to get a clear comparative picture of expenditure on exceptional needs as a proportion of all spending on assistance. or of social security spending as a whole. because few countries separate out their expenditure in the same way. For those countries where such a breakdown is available, it appears that spending on one-off payments is a uniformly minor element of all expenditure. In Finland, for example, in 1992. spending on 'preventative' payments (which can be both one-off and continuing) amounted to one per cent of total assistance expenditure. while in the Netherlands in 1990, spending on Special Assistance represented 1.5 per cent of the total on assistance (and only 65 per cent of Special Assistance was in the form of one-off payments). In New Zealand in 1993. payments of Special Needs Grants made up 0.6 per cent of all benefit expenditure. I.n the UK. total net expenditure on the Social Fund in 1993/4 represented 1.4 per cent of expenditure on Income Support, and thus an even smaller percentage of spending on means-tested benefits as a whole.

While the provision of one-off payments has been lar ${ }^{\mathrm{g}}$ ely uncontroversial in most countries, in the UK. the USA, and to a lesser extent in Canada. it has been an issue around which welfare rights movements and campaign groups have traditionally organised. To some extent this has reflected views about the inadequacy of the basic scale rates. but it has also been connected with longstanding debates about rights versus discretion in the provision of assistance payments. There also appears to be some relationship between the level of debate concerning the meeting of exceptional needs and the relative importance of assistance in relation to social insurance schemes and other elements of social security. The trend currently appears to be moving in two different directions. depending on the nature of different assistance schemes. The response by governments in both the UK and the USA has been to attempt to move away from entitlement-based exceptional payments by establishing more categorical income support premiums (in the UK) and more standardised budget guidelines (in the USA). leaving other needs to be met on a more discretionary basis and within fixed budgets. In the Netherlands too, the trend is towards allowing local authorities more discretion on how they distribute Special Assistance, but again within a cashlimited framework. In the southern European countries, on the other hand, where assistance schemes are less comprehensive or already largely discretionary, and where the charitable and voluntary sectors play a greater role in one-off help, there is a gradual trend towards a greater codification and regulation of entitlements.

\subsection{Conclusion}

This chapter has summarised and discussed the aims and principles of social assistance schemes in the countries studied, the main conditions of eligibility and entitlement, and the ways in which provision is made to meet housing costs and exceptional needs. It was suggested that although the basic principles informing different schemes are not dissimilar, the realisation of these principles in practical policy varies considerably. The first major distinction is whether minimum income guarantees are provided across the board, through a generalised scheme, or 
whether people are addressed within different cate ${ }^{\mathrm{g}}$ orical population groups, which may either exclude certain groups or offer preferential treatment to particular ${ }^{g}$ roups seen as more important or deserving. At present the preference of the majority of countries is still to offer protection by category.

In terms of inclusiveness, most general schemes allow independent claims no earlier than the age of 18 , unless young people have or are about to have children, or face particular hardship. There is little evidence available about whether this causes widespread problems. or whether the presumption of parental support below this age is well-founded. This would need to be the subject of a special study. Minimum age thresholds also have to be seen in the context of other forms of support through training and labour market programmes. Two countries which stand out in restricting eli ${ }^{\mathrm{g}}$ ibility by higher age limits are France and Luxembourg both also countries with the most restrictive residence conditions. In general, more than half the countries studied. including half the EU members. have some prior residence conditions, as well as limiting the availability of help for refugees and asylum-seekers.

Although all assistance schemes are based on the assumption that other income and resources must be exhausted before public assistance is available. this principle has, in practice, been modified in a variety of ways. There is a wide variation in the level and type of earnings or other income exempted from means-testing, based on different countries' expectations of family support, the emphasis placed on work incentives, their attitudes to cohabitation and lone parenthood, and the relative importance of assistance schemes in wider income maintenance systems.

Most countries meet some or all of the housing costs of people with incomes low enough to receive social assistance, and this help is generally extended to owneroccupiers as well as to tenants (though sometimes with some restrictions). The main distinction is between those countries which provide help as part of the general social assistance payment (and only for assistance recipients) and those with a general housing benefit scheme open to other people on low incomes. Some countries do both of these, but those in the first category might be expected to have greater problems with work incentives.

The differences between countries are also reflected in approaches to meeting exceptional or urgent needs. The question of discretionary and geographicallyvariable decision making, which ${ }^{\mathrm{g}}$ overns exceptional payments in most countries, is subject to criticism and debate in a number of them. Yet the low profile of social assistance, combined in some countries with payments which are relatively generous. have contributed to what appears to be a greater consensus or legitimacy in this area in many countries than might be expected from a UK perspective.

The next chapter takes this discussion further by looking at the administration and delivery of assistance benefits. 


\section{Chapter 4 Administration and Delivery of Social Assistance Benefits}

\section{4,1 Introduction}

Administrative structures and procedures for the delivery of social assistance benefits are inevitably complex. There is no such thing as a simple social assistance scheme. Moreover, as we have seen, there are important differences between countries in the way they organise and deliver the administration of social assistance benefits. Some, like the United Kingdom. have a predominantly integrated and national scheme with common rules of eligibility and common levels of payment. There are, conversely, other countries such as Norway and Switzerland where responsibility is devolved almost entirely to the local level. In some countries there is a single, national ministry, with responsibility for the administration of benefits: in others there are a variety of agencies and authorities. Similarly there are variations in funding principles and procedures. This chapter seeks to report the range of delivery systems, the extent to which they are complex or simple and the division between central and local responsibilities. For more detail on the administrative structure and operations of social assistance schemes readers are referred to the individual country chapters in Volume Two.

\subsection{Centre-local responsibilities}

Countries which have devolved responsibility for both the financing and administration of benefits to the regional or local level (including Austria, latterly France for the RMI, Italy. Spain and Switzerland) frequently face a dilemma: it is often those regions or local authorities with the lowest potential funding capacity which have the highest demand on social assistance benefits. This contradiction does little to promote social cohesion or spatial equity. There is little evidence that regionally organised schemes take account of increased cost of living in, for example, capital cities. Indeed it is the perception of many experts (such as Pfeil, 1994, commenting on Austria) that debates about levels of responsibility and accountability for social assistance between regions and national authorities are often more concerned with the distribution of political power or control of expenditure than with the efficient management of social assistance arrangements. These tensions are being experienced in Canada, where the Federal Government decided, in .1990, that it could no longer be held accountable for expenditures over which it had not control and 'capped spending in the wealthier provinces of Ontario, Alberta and British Columbia, and has since embarked on a more radical programme of reform which gives provinces and territories more autonomy but less central finance.

Belgium too has experienced some difficulties in the distribution of finance for the Minimex. Administrative structures are highly complex, and responsibility for funding the Minimex is split between national tax revenue and the municipalities. There is some evidence that the poorer local authorities (with the highest numbers dependent on Minimex) are under increasing financial pressure, with consequential differences in treatment of similar claimants in different areas.

In Finland, social assistance has been administered by municipal offices of social welfare in local communities, within general guidelines set by the Ministry of Social Affairs which provided broadly common conditions of eligibility and procedures for claiming. In 1991. however, under pressure from rising levels of unemployment, many of the normative directives were abolished, leading to greater municipal discretion and increasing variation of treatment. The financial burden on local 
authorities means that in some locations there are more rigid enforcement and compliance procedures, and research suggests that discretion is often applied in a negative direction. There is currently considerable demand from local authorities for increased central funding.

In France a three-tier structure of social assistance has developed which covers the social minima, other income-tested benefits (including housing and family benefits) and local social assistance. which is frequently in the form of services rather than cash. The group of eight social minima. nationally regulated and mostly funded from the central state, are now dominated by the Revenu Minimum \& Insertion (RMI), which has become the principal assistance benefit for people of workin $\mathrm{g}$ age. The various minima, being partly supplements for insurance benefits, are administered by the different branches of the social insurance system. Several benefits (RAH, Allocation aux Adcltes Handzcapes, Allocation de Parent Isole are delivered by the local Caisse d'Allocation Familiales; the Minimum Invalidite is administered by the Branche aladie; the Allocation Veurage by the Branche Vieillesse; the Allocation de Solidarite Specijgr.re is administered by the Brunelle Chomage. Some of these benefits are partly financed by contributions and the remainder by variable levels of support direct from the state. The interaction between various benefits is complex and not always well understood.

Luxembourg also has a somewhat complex system, which divides responsibility for assessment of benefit between local and central government. Administration is coordinated by a series of inter-ministerial bodies. In principle, payments for the first three months of a claim are the responsibility of the local authority. after which time it should be assumed by the Fonds National de Solidarite. In practice, however, claimants often receive payments from the local office for up to a year. As these are at a lower rate, and are often subject to delays and inconsistencies, this can cause a number of problems (Wagner, 1994).

Until recently, social assistance in the Netherlands has been 90 per cent financed by central government. This proportion has been reduced to 80 per cent in an attempt to provide incentives to contain expenditure, and Special Assistance has, since 1991 , been provided by means of cash-limited block grants rather than by reimbursement of actual expenditure. In Japan. 75 per cent of the costs of social assistance are met by central government, while in Sweden the bulk of assistance expenditure is borne by the local authorities. out of local income tax revenues. Central government finances local authority help for refugees in their first three years of residence. In Norway, local authorities receive funding for social assistance in the form of block grants from central government, based on the numbers of people in receipt of assistance.

Switzerland is perhaps the extreme case here, since, although national guidelines for social assistance exists, the schemes are administered within the framework of cantonal law. and with further decentralisation to the communes. As a result there are, in effect, more than 3,000 different schemes operating. These schemes are funded at a local level. Complex rules exist which require inter-cantonal reimbursements when people move from one area to another. leading to an intricate administrative network.

The system of social assistance in the USA is extensive, fragmented and categorical. Supplemental Security Income (SSI) and Food Stamps are both federally funded and administered, with optional additions to SSI paid by some states. General Assistance provides local social assistance in most, but not all, states. Aid to Families with Dependent Children is a jointly-funded and stateadministered scheme, which is federally regulated. There is a high degree of complexity and only limited co-ordination between the schemes.

The main examples of large-scale social assistance schemes which are both organised and funded nationally are those of Australia, New Zealand and the UK. The potential for co-ordination of schemes, such as the development of unified 
eligibility criteria, means that these schemes are also characteristically simpler and cheaper to administer. This is also the case for those elements of social assistance which have a national structure in other countries. such as the USA. Standards of administrative justice are commonly perceived to be higher in such schemes, mainly owing to improved consistency of decision making. though defenders of the locallyorganised systems argue that they are capable of greater responsiveness to individual needs.

Several countries are currently undergoing a period of transition between centralised and decentralised systems, reflecting a shifting balance of priorities. Canada, for example, is in the process of a major upheaval in social welfare which will result in greater provincial autonomy. but which critics argue is influenced primarily by a perceived need to reduce social security expenditure. In Denmark, on the other hand_ municipal discretion has been reducing steadily since 1976, with an increasing number of central directives being issued specifying eligibility criteria and benefit levels. This does not appear to be contentious. in contrast to Norway where municipalities have been seeking to control levels of payment_which are primarily locally financed. Spain is still in the process of moving towards a decentralised system after years of highly centralised administration. Whether political and expenditure control is thought to he achieved more readily by centralised or decentralised systems may reflect fundamental cultural and historical differences between countries.

\subsection{Making a claim and receiving a payment}

In most countries it is necessary for individuals to initiate their claim in person by visiting their local social security office (see Table 4.1 below). In Canada, in addition to submitting the application in person each applicant must be interviewed by a case worker either in the applicant's home or in the case worker's office. However, there are exceptions to the requirement to make claims in person: in Australia. if a claimant is old, has certain disabilities or lives in a remote location, postal application is allowed. The UK is unusual in that the preferred method of claim (except for the unemployed) is by post. In France. Germany, and Turkey claims may be made either in person or by post, as the claimant wishes. In the USA claims for Supplemental Security Income may be made by telephone using a free telephone service. Outreach facilities have been developed in Australia in order to improve access for homeless people. minority groups and other people living in remote areas.

A variety of payment mechanisms exist: in Australia over 95 per cent of benefit payments are made directly to claimants' bank accounts. In Austria. long-term benefits tend to be paid by credit transfer, but short-term and one-off payments are usually paid in cash from a district office. In Finland it is virtually unknown for claimants to receive benefits in cash, with transfers being direct to the recipient's bank account. Cash payments in an emergency are available in a number of countries including Belgium, the UK and Sweden. In Ireland, particular benefits have tended to be associated with particular payment methods, but there are now moves to streamline payment systems, with the majority of people receiving payment via an order book or post office draft. Bank credit transfers appear to be increasingly used in the majority of countries. In certain situations. individuals may be required to attend an office personally to collect a payment. This happens in Luxembourg during the initial period of a claim, and can cause significant delays and inconvenience. Personal collection of payments may also be used as a sanction where fraud is suspected. as happens in the UK in a minority of cases.

Table 4.1 summarises the administrative procedures for claiming assistance, reviewing entitlements and controlling fraud and abuse. 
Country

Generally clients have to make personal applications at the offices of the OSS. In certain cases. such as remote dwelling, old age and disability. postal applications are allowed. Visiting services exist for remote communities, and in 1993 trials were put in place with mobile vans to provide a direct service to the homeless. Aboriginals and

Torres Strait islanders, and remote communities. Over 135 per cent of payments are made directly to claimants' bank accounts.

Austria Application for Snricrl/zilfiis usually made in person, but can be made in writing;

Longer-term benefits are normally paid directly into clients' bank aect>unts, while short-term payments are usually paid in cash.

Claims for the Minirnex can be made to the local OCMW centre in person or in writing. If the person needs immediate help then some nay be given but not always in the form of cash. The centre must then appoint a social welfare officer to make a `social enquiry'. A decision trust be made in 30 days and claims are backdated. The payment can be in the forth of a postal order, giro cheque or credit transfer, lit the OCMW's discretion. apply using prescribed forms and to submit their-forms to the nearest office. Some provinces demand periodic re-verification of claim. Depending on case and province, benefits may he paid monthly or fortnightly by cheque. cash, direct payment for goods and services, credit transfer, or voucher. Direct payment is becoming the most common method. and vouchers are the most unpopular.

Procedures for verification of identity

People must satisfy proof of identity requirements (POI). When initially claiming service pensions applicants need to provide a valid tax file number and produce identity of age and service. Othe forms of identity can be birth certificates and proof of assets.

Documents needed to authenticate a claim include identity cards, residen registration, proof of income and tenancy coin ruts. The actual procedures fo verification are not legally regulated and vary between local authorities.

Itome visits may be used to verify information in cases of longer-term awards.

\section{No information}

Applicants mast. provide evidence of identity and circumstances in the tornn of birth certificates, social insurance number, medical certificates, bank books and cheque stubs.

They must also sign a form authorising officers to check bank accounts and other m 'estments.

\section{Review of eligibility}

Clients are selected for review to check continued entitlement by data-matching risk-based selection according to client group. Additional reviews, either in person or by mail are carried out. vary according to the client group.
Payments for people in retirement homes oroil fixed long-tern benefits (such as pensioner's) are usually' reviewed annually

\section{fraud control}

The DSS has a comprehensive system for controlling fraud, involving careful checking of claimant details and ID before payments are made, and extensive computer data-matching with income Tax and other external agencies
Full reviews of entitlement for the Minirnex take place only once a year, though claimants have to report changes in circumstances
Information supplied by the client is checked and verified with the Social Security Institute, the Labour Eixefi ange, and local registration offices. There is little evidence on the extent of fraud.
Some provinces demand periodic formal reapplication (monthly for young enaployaables', quarterly or annually for longer-term cases). Other provinces require clients to return payment cheque stubs as part of the ongoing process of claim renewal,
Local social workers carry out and prevent. fraud. No evidence on its extent. substantial checks on claims to detect

The prevention of fraud is a major issue for the provinces Measures include 'double verification' (by two officers). personal collection of payment cheques, direct payment into hank accounts, and increasing information-sharing between jnisdictions and departments. 


\begin{tabular}{|c|c|c|c|c|}
\hline Country & Making a claim & Procedures for verification of identity & Review of eligibility & Fraud control \\
\hline Denmark & $\begin{array}{l}\text { People apply in person within their } \\
\text { municipality by attending their local office. } \\
\text { Social workers produce booklets to help } \\
\text { claimants understand their rights and } \\
\text { entitlements. } \\
\text { Payment made monthly, normally into bank } \\
\text { or pc-tat office accounts by credit transfer. }\end{array}$ & $\begin{array}{l}\text { There are no rules governing identity: it is } \\
\text { Up to the n.=..inicipa.lity to identify the } \\
\text { client. However, applicants must have an } \\
\text { address to claim. }\end{array}$ & $\begin{array}{l}\text { Recipients must report changes of } \\
\text { circumstances, but no specific } \\
\text { arrangements for review or renewal of } \\
\text { claims. Varies according to the local } \\
\text { authority. }\end{array}$ & $\begin{array}{l}\text { The mumcipahty has the right to request } \\
\text { computeosed Infoamat.ion about } \\
\text { claimants from other sources }\end{array}$ \\
\hline Finland & $\begin{array}{l}\text { Applied Ella : an be made either in writinl? } \\
\text { or in pin -',- } \sim \text { " the welfare office. Renewed } \\
\text { claims can be made by telephone. } \\
\text { Most claimants receive benefit by credit } \\
\text { transfer to their bank account. Paying } \\
\text { benefits in cash is only possible in an } \\
\text { emergency such as for food. } \\
\text { Payment is usually monthly, }\end{array}$ & $\begin{array}{l}\text { The claimant needs to produce an identity } \\
\text { card, proof of income, bank statement and } \\
\text { municipal registration form }\end{array}$ & $\begin{array}{l}\text { The review date varies from once a month } \\
\text { in rural areas, to up to six months in areas } \\
\text { with large caseloads }\end{array}$ & $\begin{array}{l}\text { No special arrangements exist and the } \\
\text { onus is on officials to detect and control, } \\
\text { The Social Welfare Act obliges the tax } \\
\text { office to co-operate with the social } \\
\text { workers. }\end{array}$ \\
\hline France & $\begin{array}{l}\text { Claimants can apply by post or in person } \\
\text { and they are normally invited for interview. } \\
\text { There are no cash payments, except to } \\
\text { homeless people. Benefit is normally paid } \\
\text { directly into hank or postal accounts. }\end{array}$ & $\begin{array}{l}\text { Identity has to be proved 'by any } \\
\text { recognised means' }\end{array}$ & No information & $\begin{array}{l}\text { During 1994, the growth in claims for } \\
\text { the RMI in the Paris region has } \\
\text { accentuated concerns over fraud. I-Ionie } \\
\text { visits are more frequent. }\end{array}$ \\
\hline Germany & $\begin{array}{l}\mathrm{CI} \text { in a nts are usually expected to apply in } \\
\text { person at a social welfare office, although } \\
\text { claims can also be made in writing. } \\
\text { Payments are normally made monthly and } \\
\text { claimants are encouraged to have them paid } \\
\text { directly into bank accounts. Emergency } \\
\text { payments can be made over the counter and } \\
\text { more frequent or cash payments made in } \\
\text { special circumstances. }\end{array}$ & No Information & Claims are genera llyy reviewed annually & $\begin{array}{l}\text { Local social welfare officers are } \\
\text { supposed to setuianrse claims thoroughly, } \\
\text { but there has not been much debate about } \\
\text { fraud. If the office is suspicious there } \\
\text { will he an investigation, but generally the } \\
\text { claimant is trusted. Anonymous letters } \\
\text { are only taken notice of if some suspicion } \\
\text { of fraud already exists. }\end{array}$ \\
\hline Greece & $\begin{array}{l}\text { Application in person or by post to relevant } \\
\text { organisation }\end{array}$ & $\begin{array}{l}\text { Identity card and declaration that } \\
\text { circumstances are honestly presented }\end{array}$ & No information & $\begin{array}{l}\text { Concern about fraud exists, but there are } \\
\text { no special measures }\end{array}$ \\
\hline Iceland & Applications in person at welfare office & $\begin{array}{l}\text { Proof of legal residency required, plus } \\
\text { proof of income (bank statements and tax } \\
\text { returns) }\end{array}$ & $\begin{array}{l}\text { Claims reviewed every I to } 3 \text { months, } \\
\text { depending on local authority }\end{array}$ & $\begin{array}{l}\text { Ministry of Social Affairs issues guidelines } \\
\text { on detection of fraud. Social Service } \\
\text { committees have access to information } \\
\text { from employers on wages and to the } \\
\text { computerised systems of the National } \\
\text { Insurance Office and Social Insurance } \\
\text { Institute, but the client's consent } \\
\text { must be given for information gathering. }\end{array}$ \\
\hline
\end{tabular}




\section{Country Making a claim}

Ireland

(h) local welthrc office. Supplementary

Welfare Allowance and Disabled Person's Allowance are paid by the local health board. All other benefits are applied for by post, centrally All payments are made weekly. Each scheme has a method of payment associated with it: tot example. cash for the unemployed, order hooks for most other social assistance recipients and cheques rot health hoard payments.

Social workers play at large part in the claiming process. receiving and dealing with the application and also providing counselling.

Payments of the social pension are made directly into post office or hank accounts every two months.

Payment systems for local social assistance vary according to the municipality.

To make a claim a person must apply to the welfare office in the relevant town, village or city. Payments are made monthly, in cash at welfare offices or by credit transfer to bank accounts.

I.,uxemhourg A claim for the RMG must be trade to the
local municipal social welfare office. but there is no specific application form. Afte three 'months of claiming, administration should pass to an office of the national Fonds A umsrtal tic Solidrtrite, though the initial period can last longer.

Initial payments are made at $80^{\prime} \%$ of the full rate, usually weekly in cash. ENS payments are made monthly by credit transfer.

Procedures for verification of identity

In order to claim social assistance people must quote their revenue and social insurance numbers. They may also be required to show other proof of identity (for example a birth certificate is require for Unemployment Assistance and most pensions).

Review of eligibility

Fraud control

There is a home visiting service which can

lae used to verify circumstances and to

review elig ibility
Departmental records and computer systems are used to detect any faulty payments. Certain employers have to notify the Department of Social Welfare about new employees and subcontractors.

A joint Revenne.Soetal Welfare Interdepartmental Unit employs special f'rand investigators. Order h been redesigned to prevent $\mathbf{n} \cdot$ 'gery.

No information
There is no system of identity cards for receipt of assistance

No infortrtation

formal requirements for review of as house visits
The renewal of a claim is not necessary if circumstances do not change. Case workers visit claimants regularly to cheek their eircumstances and offer guidance $=$.
The Ministry provides guidance for local authorities in detecting and controlling fraud, which is punishable by a maximum of 3 years imprisonment or a fine of up to $50.000 \mathrm{Yen}$

The enquiries made when assessing a claim are seen to be sufficient by the offleetIs to detect frau 


\section{Country Making a claim}

Netherlands

Payments are usually paid directly to the person's bank account through a credit transfer on a monthly basis. In special circumstances such as hotuelessness payments can be made more regularly. It is possible for the payments to be made to another party on behalf of the claimant hut only with the permission of the claimant.

Applications are usually made by

completing an application form and a face to face interview. All benefits are paic fortnightly, except the unemploymentrelated benefits which are paid weekly. All payments are by credit transfer.

Norway People can either send in an application form or go to the local office to get hel with completing the form. There is no obligatory home visiting service.

Methods of payment vary by municipality. but generally, shorter-term claimants such as the young unemployed have to re-apply each month and are paid by cheque, whereas longer-term recipients receive monthly payments by credit transfer.

Portugal Benefits are usually claimed in person at the local social security offices. Payments are made monthly, by postal order.

Spain $\quad$ For the minimum income benefits. claimants are required to make a personal and detailed application at the district and detailed application at the distic council within each Autonomous
Community. Payments are made monthly and credit transfer is the most popular means of a m lint.

\section{Procedures for verification of identity}

National identity card is required for initial claim

Review of eligibility

People are required to sign on once a month if they are available to work and their case is reviewed every eight month

Claimants have to show proof of identity when they apply, and they are then allocated a DSW number

If necessary people will have to prove their identity to make a claim
Entitlements are renewed annually for invalids. Widows, Domestic Purposes and Transitional Retirement Benefits, as well as for Superannuation. Renewals of Sickness. Training and Ilaaemployment benefits vary according to circumstances

Review procedures vary considerably both by local authority and claimant category
Fraud control

Two national commissions in the early 1990s suggested that fraud in social assistance was extensive and focal authorities have been encouraged to tighten up procedures, Social service computer files are now linked to those of tax and national insurance offices.

There are a number of strategies to detect fraud: internal controls and audits, the use of investigation units and officers. use of investigation units and officers. from different agencies

In order to control fraud, social services have access to information on their clients from other authorities. Fraud is not a major issue, however.
Claimants are given an identification card and number when they first claim assistance

Claims must be supported by proof such as an identity card or passpor
There are no formal arrangements for the reviewing of a claim. However, a person's circumstances can periodically be re-

Procedures for reviewing claims vary substantially between regions
Regional social security centres have inspection teams for controlling fraud, but there is little debate on the subject

To detect fraud, data is cross checked between the National Institute of Employment, the National Institute of Social Security and regional social welfare departments
Sweden $\quad$ Apphcuttt $\sim$ $€ \mathrm{a}$.an be made through the post, but usually they are made in person at the local social security offices. Benefit is paid monthly by money order or credit transfer. It is possible to have more frequent payments in difficult circumstances.
If the person is not known then identity must be confirmed by a passport or identity card
Claims for social assistance have to be renewed in writing once a month
There is little debate on fraud, but check an be made with information from the social insurance office or unemployment benefit fond, the national register office, the motor vehicle register. and employers 


\section{Country}

Switzerland

\section{Making a claim}

Applications for benefit are normally made over a public counter (and thus can lack privacy). The majority of payments are made in cash. but the frequency varies according to the commune. In some. payments have to be collected daily.

Turkey

Claims are made by post or in person Payments are made every month or threemonthly, by whatever method the claimant prefers.

UK Income Support is claimed by post. The claimant fills in an extensive form and sends it to the local Benefits Agency office. sends it to the local Bensefis Agency office. giro or credit transfer. Payments are made usually fortnightly.

\section{Procedures for verification of identity}

Anidentity card is not required, but national insurance number is needed to access the claimant's records.

In cases of disputed identity or immigration status. passports or other forms of identification may be required

Identificmnni Mr SSE AFDC and FS is
made by social security numbers issued
by the Social Security Administration
For AFDC, appicance office. Food Stamp applications are made at the same office and monthly payments are often combined with AFDC.

Applicants for SSI can apply in person, by post or by telephone. Payment can be made either by cheque or credit transfer. For (TA, payments are usually made by cheque or by voucher

\section{Revierv of eligibility}

Procedures vary from commune for commune

A claim for Income Support is reviewed after the first 13 weeks of claiming.

Claimants must report any changes of circumstances which might affect their benefit award

\section{Fraud control}

No information on specific

arrangements, but the assessment proces for a istans $t$ is Generally very detailed and ti. and social workers have the authority to interview as wide range of people about the client's circumstances

No information

\section{Eligibility for the SST is reviewed}

periodically, but this varies from between

$1--3$ years depending on the profile of the

claimant. Eligibility for the AFDC is

reviewed every 6 months, with a face to

face interview every 12 months.
The government places groat emphasis on preventing detecting and deterring fraud. The DSS has improved

technology to detect. fraud and made delivery and payment systems more secure (such as by putting bar codes on order books). The number of prosecutions has also been increased. AFDC and SST fraud is controlled by extensive manual and computer datamatching, and field investigations 


\subsection{Procedures for verification of ide}

The extent of documentation which is required in order to make a claim varies considerably both between, and to some extent within, countries (see Table 4.1). In Denmark and Austria_for example, there are no specific legal requirements as to evidence of identity. and practice varies considerably in different areas. Australia, Canada and the UK have among the most stringent conditions, with requirements to produce proof of assets, proof of identity (such as birth certificates) and social insurance numbers. In countries with local administration of benefits, such as Sweden. identity documents are not checked on each claim if the person is already known to the office. A number of countries. including Canada and New Zealand, have considered the imposition of a national, compulsory system of identity cards for claiming social assistance, but have, up to now, rejected the idea on civil liberties grounds.

\subsection{Computerisation of benefit delivery}

Computerisation may be adopted for a number of reasons. Administrative efficiency tends to be enhanced where the majority of claims are processed by computer. as in the UK. However, this is a feasible strategy only where schemes of social assistance are reasonably simple and not subject to a large degree of administrative discretion, In Sweden, benefit authorities have access to motor vehicle tax records. which are used to check ownership. as a car is regarded as a saleable asset. While helping to contain administrative costs and limit the extent of fraud, the introduction of computerised systems has also brought advantages for claimants. For example, in Australia and New Zealand, social security authorities argue that the introduction of computerised systems has led to fuller take-up of entitlements. Portable computers are also used for home visits in Australia, with the result that the service received is comparable to that available in an office interview.

\subsection{Fraud prevention and control}

Computerisation also plays a major role in fraud control in a number of countries. There is considerable disparity in the extent to which countries regard fraud as an issue, and in the measures which are adopted in an attempt to minimise it (see Table 4.1). In those countries with recently developed systems of social assistance, such as Turkey and Portugal. there is little discussion of fraud. Fraud is also not perceived as a particular problem in Sweden or Finland, though local authorities have extensive access to tax records, motor vehicle license information and other databases. In New Zealand, also, there is considerable use of computers to detect fraud, as authority exists for the Department of Social Welfare to check databases including those for income tax, customs and excise, and college records. Other methods used include home visits, as in Japan and France: in the latter lone parents in particular appear to be subject to special scrutiny when claiming. Metropolitan areas are typically perceived as difficult to monitor and therefore more likely to experience fraudulent claiming. The UK appears to rely more on information supplied by members of the public than other countries. In Germany information such as anonymous letters tends to be ignored, unless there is existing knowledge or suspicion of fraud.

Amongst countries with a pro-active approach to fraud prevention, Ireland has targeted particular types of employers in order to prevent 'off the record' working. These are now required to notify the benefit authorities when new employees are taken on. Australia has developed sophisticated data-matching technologies which include probability estimates of the likelihood of fraud among particular client groups. Deterrence is also an important component of anti-fraud strategies, and countries such as Japan and the U.K use prosecution ('pour encourager leis autr-es') in addition to computer technology and traditional methods of detection. During the 1980s. Japan experienced some well-publicised cases of social assistance fraud by organised crime syndicates_and introduced more careful scrutiny of claims in order to ensure public confidence in the system. 
Complex, routine and regular reviews are conducted in a number of countries (see Table 4.1): among the most systematic is Australia where continued eligibility is monitored on an ongoing basis, with the frequency of checks varying according to the benefit received. In the USA review requirements also vary across benefits. with claimants of AFDC being required to attend a review interview at least once a year, with an interim six-monthly report. In some cases monthly reviews of circumstances may be undertaken.

In Canada, requirements vary between the provinces. but several demand regular re-application for benefit (every month for young, single 'employables'), and in some cases claimants are required to return a cheque stub from their benefit payment as part of a routine verification process.

In the USA, reviews take place at intervals between one and three years for different claimant groups. Failure to complete the required report on circumstances may lead to a reduction in benefit. In the UK. Income Support claims by unemployed people are subject to weekly, fortnightly. or monthly checks on job seeking activity, but otherwise are not specifically reviewed on a regular basis. In Finland, the review period varies from once a month in rural areas to six-monthly in cities. In Denmark. Spain and Norway there appears to be a high degree of geographical variation in the frequency with which claims are reviewed, since this is a matter of local policy. There are no formal requirements for benefit to be reviewed in Portugal or Turkey.

There is a general duty on the claimant to report any relevant changes in circumstances in virtually all countries, though they vary in the extent to which there are active procedures for discovering whether individuals' circumstances have altered. In Japan. for example. claimants are visited regularly at home in order to check their current circumstances, whereas the more common pattern appears to be to rely largely on self-reporting of changes.

Table 4.2 summarises procedures for recovery of overpayments, appeals against administrative decisions and wider scrutiny of the quality of administration. 
Table 4.2: $\quad$ Procedures for recovery of overpayments, appeals and see ny of administration

\begin{tabular}{ll} 
Country & Recovery of overpayments \\
\hline Australia & $\begin{array}{l}\text { Overpayments from misrepresentation or failure to } \\
\text { comply can be recovered from a DSS payment. } \\
\text { Not all overpayments arisin }\end{array}$ \\
& error are to be repaid.
\end{tabular}

Appeal systems and scrutiny of administration

Australia has a well-established system of reviews and appeal involving several tiers. These include internal reviews, appeals to the independent Social Security Appeal Tribunal and to the federal courts on a point of law. Administration and delivery of benefits are scrutinised by a Commonwealth Ombudsman, to whom a dissatisfied client can also complain. The DSS does not have to implement the recommendations but the Ombudsman can inform the Prime Minister and Cabinet about non-implementation.

\begin{tabular}{|c|c|}
\hline Austria & $\begin{array}{l}\text { Overpayments are recovered by 'reasonable } \\
\text { repayments'. though repayments may defeat the } \\
\text { object of help if it does not stimulate people to be } \\
\text { self-sufficient. The debts can only he recovered } \\
\text { from a liable spouse or relative, a divorced spouse } \\
\text { can only be liable if there was an obligation for } \\
\text { support in the settlement of the divorce, }\end{array}$ \\
\hline
\end{tabular}

Local decisions are subject to appeal and are heard by a tribunal with provincial authority: the decision will normally take up to six months to go through, Complaints can he heard by the National Ombudsman. The administration of social assistance is subject to scrutiny by provincial governments and the provincial and federal courts of auditors.

Belgium No information about recovery mechanisms

The jurisdiction for appeals against decisions on social assistance lies with the labour courts. Appeals to the courts are stow and cumbersome. but they are regarded as providing good access to social justice.

Eanada
Every province has procedures to recover any
entitled to. Overpayments are deducted front future
benefits according to provincial formulae. Most
provinces reduce or defer repayments if they might
cause real hardship.

Under the Canada Assistance Plan every province must have an appeal procedure relating to refusal, suspension and termination of benefit. There is considerable variation. Some have limits on issues that can be appealed upon, others allow people to question any decision. There are also provincial ombudsmen. The Federal Department is subject to scrutiny and review by the federal auditor.

\begin{tabular}{lll}
\hline Denmark & $\begin{array}{l}\text { Arrangements for repayment are dependent on the } \\
\text { circumstances that led to the overpayment. The } \\
\text { local municipality can decide how the payment } \\
\text { should be repaid. Only the person who was }\end{array}$ & $\begin{array}{l}\text { There is a right of appeal first to the local Social } \\
\text { Board, then to the County Board. Final appeal to } \\
\text { central Social Appeals Committee. The }\end{array}$ \\
& $\begin{array}{l}\text { Ombudsman can scrutinize any social assistance } \\
\text { appeals. }\end{array}$
\end{tabular}

\begin{tabular}{lll}
\hline Finland & $\begin{array}{l}\text { Overpaid benefit is recovered from other social } \\
\text { security benefits. or by attachment of wages. It can } \\
\text { only be recovered from another person in the }\end{array}$ & $\begin{array}{l}\text { Appeals go first to the local Social Welfare Board } \\
\text { and then to the Count Board. No further appeal } \\
\text { beyond this level. Process can take up to a year. }\end{array}$
\end{tabular}
household if $\mathrm{s} /$ he is obli ${ }^{\mathrm{g}}$ ed to support the claimant. Overpayments can be recovered from cash from an estate but not from the home and household items.

A parliamentary Ombudsman reviews the administration of the appeals.

\begin{tabular}{ll}
\hline France & Overpayments are deducted on a percentage basis \\
& from future payments. subject to individual \\
& arrangements where other debts are involved
\end{tabular}

Appeals on the RMI and other social minima can be made to local Commissions, and for some benefits to a Social Security Tribunal. Administration is subject to scrutiny by mediators appointed by the CNAF and by a national Ombudsman concerned with all public services.
C"sermaanv Claimants must repay any claim that arises from misrepresentation. Overpayments can be recovered from the estate of a dead client if necessary.

Decisions on social assistance are subject to appeal, including discretionary decisions. First tier is review, by local or Lander welfare office. Further appeal to administrative court, where free $\mathrm{le}^{\mathrm{g}}$ al aid is available.

\begin{tabular}{lll}
\hline Greece & No information & Internal rights of appeal for most benefits \\
\hline Iceland & $\begin{array}{l}\text { Payments made on basis of false information are } \\
\text { recoverable. Overpayments as result of } \\
\text { administrative error are non-recoverable. }\end{array}$ & $\begin{array}{l}\text { Adjudication process and benefit awards are both } \\
\text { open to appeal at the national Social Services } \\
\end{array}$ \\
& $\begin{array}{l}\text { Appeal Committee, but only where decision at } \\
\text { issue is subject to regulation }\end{array}$ \\
\hline
\end{tabular}




\begin{tabular}{|c|c|c|}
\hline Country & Recovery of overpayments & Appeal systems and scrutiny of administration \\
\hline Ireland & $\begin{array}{l}\text { Overpayments are recovered from future payments } \\
\text { of benefits and income. They are only repaid by the } \\
\text { claimant or their partner. In general repayments are } \\
\text { not recovered from the estate of a dead client. } \\
\text { However, if it is proven that the client had greater } \\
\text { resources than stated in their claim, then money } \\
\text { can be recovered. }\end{array}$ & $\begin{array}{l}\text { Decisions are subject to appeal at local Social } \\
\text { Welfare Appeals Offices or Health 'Board Appeal } \\
\text { Offices, depending on benefit. Further appeal to } \\
\text { the High Court on point of law. } \\
\text { All Departments are subject to scrutiny by the } \\
\text { parliamentary Ombudsman. The Ombudsman } \\
\text { can investigate decisions made, administration } \\
\text { and failure to take action. As well as this. the } \\
\text { Comptroller and Auditor General scrutinise } \\
\text { departments. }\end{array}$ \\
\hline
\end{tabular}

sability pension decisions, but said to be 'slow and cumbersome'. Appeals on local assistance depend on locality.

Japan Any overpayments are recovered by deducting money from succeeding payments or by ordering repayment. All members of a household are liable for repayment.
Claimants dissatisfied with decision of local social welfare office can ask for local review and can also appeal directly to Prefectural Governor within 50 days of the original decision. The Governor will issue jud ${ }^{\mathrm{g}}$ ement within 50 days. Further appeal right to Minister for Health and Welfare or through courts.

\begin{tabular}{|c|c|}
\hline Luxembourg & $\begin{array}{l}\text { Benefits can he reclaimed in a number of } \\
\text { circumstances. If during a period of claim a client } \\
\text { disposes of resources which could be taken into } \\
\text { account in the claim, the excess can be reclaimed } \\
\text { from them or anyone liable to them. If a client has } \\
\text { given false information that may affect the claim, } \\
\text { repayment is obligatory. Any benefit that is } \\
\text { wrongly paid can be reclaimed. It can be reclaimed } \\
\text { from future benefit or any arrears. Benefit can be } \\
\text { reclaimed from an estate or a will, and from the } \\
\text { claimant if their situation improves. }\end{array}$ \\
\hline
\end{tabular}

Netherlands Payments can be recovered from claimants or other parties in a number of circumstances.

Overpayments made in error can be claimed from the person themselves. Assistance can be also reclaimed from an estate.

There are common procedures for appeal on all social security benefits and free representation by a lawyer is possible

Claimants have the right to administrative review (sometimes carried out by a special committee), and to further appeal at the Regional Court. which has a special social security appeal 'chamber'. Appeals can be made on exercise of

\begin{abstract}
New Zealand Overpayments may be recovered. If repayment is unreasonable then the debt will be written off. If a person is still on benefit then a reduced repayment schedule is used. such as S5 per week. Repayment can only be from the claimant or his:'her estate and not from an ex-spouse.
\end{abstract} discretion as well as on regulations.

Several sta ${ }^{\mathrm{g}}$ es of appeal include internal review review by local Benefits Review Committee Social Security Appeal Tribunal. Appeal Court, and High Court on a point of law.

Departmental operations are also subject to scrutiny by Ombudsman. Audit Department and parliamentary Select Committee.

Norway overpayments are not paid back voluntarily legal
steps can be taken to recover them, Overpayments
can only be recovered from the claimant or their
spouse.
There is provision in the law in Norway for people to appeal against any decisions made. Applicants can ask for a re-assessment of their case. The case is first heard by a committee of lay people from the local municipality. If they do not support the appeal, it goes to the County level where the final decision is made.

The municipal social services are reviewed by the County Governor.

Portugal Overpayments are recovered from future benefit or
other income, dependin ${ }^{\mathrm{g}}$ on whether the mistake is
the fault of the claimant or the institution. Benefit
can only be recovered from claimants themselves.

Claimants may challenge decisions if they think that they have had their rights infringed. Appeals ${ }_{a}{ }^{g}$ ainst decisions are lodged first with the relevant administrative institution and then with the administrative courts. The Ombudsman can also receive complaints, but cannot issue binding recommendations. 
Table 4.2: $\quad$ Procedures for recovery of overpayments, appeals and scrutiny of a inistration - $\left(c^{\circ}\right.$ ontd $)$

\begin{tabular}{lll}
\hline Country & Recovery of overpayments & Appeal systems and scrutiny of administration \\
\hline Spain & $\begin{array}{l}\text { Overpayments can only be reclaimed from the } \\
\text { claimant and are not recoverable from an estate }\end{array}$ & $\begin{array}{c}\text { Claimants may appeal to district authorities } \\
\text { must benefit decisions within one month of } \\
\text { receiving the decision }\end{array}$ \\
\hline
\end{tabular}

Sweden Any small overpayment received in good faith is not reclaimed. It can only be reclaimed if it is paid out as an advance against another benefit or if it has been paid to someone involved in a labour dispute. In these cases the social welfare board must be certain that a person is not left without resources because of the repayment. Payment can only be recovered from the person who received it.

Appeals on social assistance can be made to the County Administrative Court if submitted within three weeks of the decision. The County Court 's decision can be appealed by both the claimant and the social welfare board. at the

Administrative Court of Appeal. The Supreme Administrative Court is the final place of appeal and sets le $\mathrm{g}_{\mathrm{al}}$ precedent. but only hears test cases given leave to appeal.

The county administrative board and the National Board of Health and Welfare are mainly responsible for supervising social services. Complaints may also be lodged with the Parliamentary Ombudsman.

\begin{tabular}{lll}
\hline Switzerland & $\begin{array}{l}\text { Payments are theoretically recoverable if a } \\
\text { claimant's circumstances improve }\end{array}$ & $\begin{array}{l}\text { Right of appeal exists but procedures vary } \\
\text { between Cantons. Legal aid may be available. in } \\
\text { practice appeals are rare. }\end{array}$
\end{tabular}

Turkey Overpayments are recoverable from future benefit. Legal heirs can be responsible.

There is a process of appeal written into the constitution and claimants have a ri ${ }^{\mathrm{g}}$ ht to legal representation.

UK Overpayments in general are recoverable. but only where there has been a misrepresentation or failure to disclose a material fact. Repayments can be in the form of deductions from future benefit, instalments or lump sums.

Most decisions are subject to appeal. Appeals on Income Support must be lodged within three months of original decision. Officers review cases internally $\mathrm{Fu}^{\mathrm{T}}$ st and if the decision is not changed it goes to the independent Social Security Appeal Tribunal. Further appeal, on points of law only. can go to the Social Security Commissioners. whose decisions are binding on tribunals, and then to the Court of Appeal.

The Benefits $\mathrm{A}^{\mathrm{g}}$ ency is subject to scrutiny by the National Audit office on behalf of Parliament and by the House of Commons Social Security Advisory Committee. Complaints about maladministration can be heard by the Parliamentary Ombudsman.

Well established national appeal procedures exist for 55I. in four tiers. AFDC has only one tier of appeal..... 'fair hearing' before the state $\mathrm{a}^{\mathrm{g}}$ ency or 'evidential hearing' at local level. Procedures for GA depend on the state.

\subsection{Recovery of overpayments}

Again there is a broadly similar pattern of procedures for recovering overpayments of benefit across the countries. Generally overpayments resulting from some mistake or misrepresentation on the claimant's part are liable for recovery, either by deductions from future benefit, by separate debt recovery or through attachment of earnings. Mistakes made as result of official errors are less likely to be recoverable. In countries where there is greater discretion in decision making in general, this discretion is likely to apply to overpayment recovery too. It is also noticeable that recovery of overpaid benefit from the estate of deceased claimants is commonly permitted, although it is not known how often this actually happens.

\subsection{Provision for payment of benefit to third parties}

Several countries make provision for deductions to be made from benefit to meet debts, such as for fuel and housing costs. These include Australia. Finland. Norway, the Netherlands, Sweden, and the UK. Direct payments are made in between a quarter and a third of all cases in the Netherlands. In the UK, by 
contrast (if deductions for repayment of Social Fund loans are excluded). the proportion of claimants who have payments made directly from their benefit to third parties is consistently below five per cent. However, the total number of direct payments trebled between 1991 and 1993, from 486,000 to $1 . € 28.000$ (Man.nion et al.. 1994). Rules governing the situations where such deductions may be made appear to be most developed in the UK. In Australia. rent arrears are specifically excluded. In Norway. such assistance may be conditional on the acceptance of considerable social work intervention. In Finland, occasional lumpsum payments are sometimes used to prevent the need for deductions from benefit. Deductions from benefit to meet debts cannot be made in Denmark or France. There is little information on the use of direct deductions from benefit in the other countries, although it appears that lump-sum payments which are available in Belgium, Denmark.. Portugal and Ireland may lessen the necessity to incur debts for essential items. Discretionary awards of weekly benefit (for the higher heating bills of disabled people, for example) are also made in some countries.

\subsection{The role of social workers}

In a number of countries social workers play an important role in the assessment and delivery of social assistance benefits. The potential for payment of benefits to be explicitly linked to behavioural change (especially job search activity) appears to be most highly developed in Japan and Switzerland where detailed and personal interviews with social workers are common. In the Scandinavian countries, where social workers have traditionally had a dual role as counsellors and benefit administrators, there is evidence that they are experiencing increasing difficulty in reconciling the contradictions which arise. In Italy, where they also have this dual function, there appears to be less concern about potential conflicts of interest. In the Netherlands, the teams of benefit administrators include a legal expert, in addition to trained social work staff, in order to facilitate decision making. The social worker as benefit administrator is associated with local funding and administration of benefit. and is thus not found in those countries with a national system of benefit. In countries where social workers have no involvement in the administration of benefits. they may nevertheless play an important role in providing advice and information, as in France and the UK.

\subsection{The role of non-governmental organisations}

Non-governmental organisations (NGOs) have a number of potential roles in relation to schemes of social assistance. One role is to act as campaigning bodies, monitoring policy and administration of benefits and providing representation for claimants. This 'poverty lobby' or 'welfare rights' function is well-developed in a number of countries and is discussed in more detail in the next chapter. They may also be involved in the provision of benefits and services, although typically these are in kind, rather than cash. In certain countries, such as Germany and Portugal, some NGO are 'incorporated' into the system of social assistance. In Germany this takes the form of provision of services such as residential care. The contractual relationship between these voluntary agencies and the social assistance authorities is regulated by law. In Japan, there are a number of NGOs which are involved in service provision, such as training schemes. accommodation for homeless people and care for elderly or disabled people. Switzerland has an extensive network of NGOs which, in some of the smaller communes at least, functions as an alternative system of assistance for people who are unable or unwilling to make use of the rather stigmatised formal social assistance scheme. In other countries such as Italy, where social assistance provision for some groups is very limited, religious and voluntary bodies also play an important role in providing substitute assistance. The growth of such organisations as food banks in Canada and New Zealand is also indicative of increasing levels of need. It is said that claimants in New Zealand are often referred to such organisations by the benefit authorities, as much for their role in providing advocacy as for the practical aid which they offer. In Luxembourg and Austria. some NGOs can make cash payments, sometimes in emergencies, for which they are later reimbursed through social assistance. The importance of NGOs appears to be increasing at present, and even in those 
countries where they have traditionally played a very limited role, such as Denmark and Finland, they are becoming more significant. Their relevance to schemes of social assistance is still regarded as marginal, however, in the Nordic countries. Organisations which play a role comparable to that of the voluntary sector in the UK are few, and marginal to the administration of social assistance. In the UK, NGOs have tended to be wary of policy changes which could in ${ }^{\mathrm{v}}$ olve their substituting for statutory provision, on the grounds that this might undermine their independent role.

\subsubsection{Quality and scrutiny of administration}

The term 'quality' is highly contested and despite a growing interest in its meaning and application in the general field of management and administration, there is little evidence that it has been subject to systematic evaluation in the context of social security. The general correlates of quality include accessibility, acceptability, equity, efficiency, effectiveness and, more recently. customer service. The established portfolio of social security research has focused primarily on inputs (the volume of resource), outputs (numbers in receipt of benefit) or outcomes (distributional impact or standard of living) rather than on process of benefit delivery. The UK appears to be one of the countries where claimants' views on service delivery are sought using regular attitudinal surveys (see, for example, Russell and Whitworth. 1991: Smith and Wright, 1993).

This chapter has described the structures and processes by which claims are initiated, benefits received and redress of grievance provided. No firm conclusions can be drawn on the basis of available evidence. But to ignore or avoid the issue of quality in relation to benefit adjudication and delivery would be to disregard a commitment which is at the heart of policy agendas in most social security systems. It is evident. certainly in the British context and exemplified by the establishment of 'Next Steps' executive agencies responsible for the implementation of social security policy (Ibbs Report. 1989; Department of Social Security, 1995), that there is growing interest in quality processes of benefit delivery: whether claimants have easy access, are treated courteously, are well informed, are paid promptly (Ditch, 1994). This is not to detract from the significance of either benefit levels or outcomes, but is a recognition that how systems are organised to provide a service is important for policy maker and claimant alike.

For a number of the countries there is very little evidence about the quality of administrative decision making. In the Netherlands, there is a strong perception that speed is prioritised to an extent which seriously prejudices the quality of decisions on claims (Commission van der Zwan, 1993). The administration of the social assistance scheme in Finland has been criticised as deteriorating rapidly under the weight of increasing numbers of claims (Lauronen and Lehto, 1991: Lehto and Laminipaa, 1992; Mantysaari, 1993). Administrative efficiency is also regarded as problematic in Norway (Terum, 1994).

There is considerable variation in the rights of appeal which are available to dissatisfied claimants (Table 4.2). These rights may include local or internal reviews, appeals to specialist courts, and hearings in general courts. The appeals system in Turkey is described as straightforward and equitable though no information is available about its actual usage in assistance cases. In Canada. rights of appeal vary across provinces, and there have been recent moves to limit the range of decisions which carry appeal rights. Nonetheless, there has been a marked increase in the number of appeals in the early I 990s - a period of benefit cuts. By contrast, the appeals system in Switzerland is apparently hardly used. while in Finland too there appears to be Iittle confidence in the appeals structure, resulting in low rates of use (Tanninen and Julkenen, 1993: Huhtanen. 1994). In Italy, the appeals process is described as 'complex and slow' (Saporiti, 1994) and this can also be the case in Japan if the general courts are used (although special social assistance hearings are faster). Some countries have recently expanded opportunities for claimants to make use of appeals through the general legal 
system: this has happened in Germany, Belgium and the Netherlands_ In Belgium this was in explicit recognition of the superior quality of administrative justice available in the Labour courts, which had been demonstrated by a number of studies (van HuffeI, 1990; Bodart and Dijon. 1990; Huyse (a al., 1991). In the USA the degree of administrative discretion and the appeal rights of claimants appear to vary with the benefit received. with General Assistance offering the least rights and Supplemental Security Income the greatest. Claimants of Aid to Families with Dependent Children have the right to only one hearing. which is at the state agency level.

Although appeals to specialist tribunals or courts are free of charge in most countries. there are usually some costs associated with use of the mainstream courts. It is also often the case that claimants' success at appeals may be increased by legal or para-legal representation, and a number of countries provide legal aid for social assistance tribunals.

\subsection{Conclusion}

Social assistance schemes are a product of the overall structure of social protection within each country and of the prevailing constitutional and political arrangements. Of necessity, all social assistance schemes are complex, as they seek to adjust to the diverse and changing needs of claimants on the one hand and the interests of tax payers and employers on the other. Certain aspects of the administrative process, such as methods of application and payment, reporting requirements on claimants and recovery of overpayments. seem. at least in principle, broadly similar in most countries. Mechanisms for fraud control and detection. and procedures for appeal and redress, seem more variable and reflect to a greater extent the differences in context and scale between the various systems. However, more research needs to be undertaken looking in detail at the practicalities of administration 'on the ground' in the different countries if we are to understand better the role of administration and benefit delivery in the translation of policy objectives into outcomes. 


\section{Chapter 5 Benefit Rates, Adequacy and Take-up: National Debates}

\subsection{Introduction}

So far this report has discussed the growing importance of the different forms of social assistance in the OECD countries and examined the structure and administration of different schemes. Clearly one of the key features of assistance schemes is the level of support available and the next chapter compares the financial value of benefits fora range of model family types. First, in this chapter. we examine how benefit rates are set and uprated. We then briefly survey debates in the different countries on poverty and the role of social assistance in preventing or alleviating it. In some countries, non-governmental organisations and 'poverty lobbies' play an important part in these debates and their role is considered here too. One of the key question is whether assistance benefit levels in the different countries are generally viewed as sufficient, given the role social assistance plays in wider social security systems. Although to do justice to the range of debate on these topics requires a full study in itself, some information was provided by the national informants which helps to contextualise the empirical findings. Meanstested benefits, however, can only play their intended role if people with insufficient resources take up their entitlements. The final section of the chapter briefly reviews the limited evidence on take-up of assistance.

\subsection{The construction of social assistance scales}

As we have seen in earlier chapters. social assistance schemes in a number of the countries in the OECD are administered by local, regional or provincial tiers of government rather than by national-level departments. Despite this, however, benefit rates are set nationally in more than half the countries, whether or not assistance is locally administered. and do not vary (except for the discretionary elements) at a local level. In several others there is regional variation within national guidelines or limits, and in only a few countries are re ${ }^{g_{i o n a l}}$ or municipal authorities entirely free to set their own rates. Even in these Iatter countries there is often a distinction between means- or income-tested benefits which are supplements or replacements for insurance benefits (including unemployment assistance and supplementary pensions), and general or categorical basic assistance payments: the former are usually administered by insurance institutes and have national rates. Countries with locally administered assistance schemes, but national guidelines for benefit rates, include Germany, where rates vary only marginally between the Lander: Finland, which has recommended national rates at two levels related to local variation in the cost of living; Japan, which has six geographical cost-of-living bands; Iceland, where minimum rates are set nationally: Switzerland, where there are national guidelines but wide local variation in actual payments; and Sweden. Sweden has national recommended rates. but the courts have ruled that if a local municipality refuses to give a claimant the minimum recommended rates of social assistance recommended by the government $\mathrm{s} /$ he is entitled to call on bailiffs, supported by the police, to seize from the municipality up to the value of the minimum entitlement. According to the Swedish National Board of Health and Welfare, however, this has only happened once. Austria, Canada, Norway, Spain and Italy (for the local Minimo Vitale) seem to be the only countries where both administration and the setting of rates are entirely the responsibility of the provinces or municipalities. In all other countries there are national social assistance scales.

Every country for which we have information, except Norway, has a general understanding that assistance benefits will be uprated regularly. The minimum 
benefits which exist in Greece are not indexed and where they are uprated this is only by Ministerial, or in some cases Presidential, decision. In most countries uprating takes place annually, though it is not clear for all countries whether this is a statutory obligation. Australia, Italy. Germany, France and the Netherlands uprate twice yearly, and Turkey. which has experienced high levels of inflation, uprates benefits quarterly. The most common uprating formula is to change benefits in line with movements in the consumer prices index. In Belgium the index was recently altered to exclude cigarettes, alcohol and petrol. and in the UK it excludes housing costs, where rent is fully covered by housing benefit in most cases. The countries which use formulae other than prices are Austria, Denmark and Finland. where benefits are linked to an earnings index or to another benefit which itself is linked to an earnings index - thus Denmark links social assistance to unemployment benefit_which is in turn uprated in line with earnings. In Japan social assistance has been maintained since the early 1980s at 69 per cent of the consumption level of the general household, while Germany uses an index of the expenditure of' the lower third of the income distribution.

The formula used for uprating benefit is not necessarily related to that used to set benefit levels in the first place. The information provided on the original rationale for the level of benefits was not always very detailed, perhaps because in a number of countries if such a rationale had existed, it had been superseded by subsequent incremental changes. In the U.K.. for example. the original national assistance scale rates have their origins in the recommendations of the Beveridge Report (Beveridge. 1942), which in turn drew on the minimum subsistence budget derived from Rowntree's 1936 study of poverty in York (Rowntree. 1937). In the post-war period. the scales were initially $\bullet$ uprated rather haphazardly, but had more or less doubled in real terms by 1979 , maintaining their value relative to earnings. Since 1980, they have been uprated mainly in line with movements in the Retail Price Index (with some exceptions --- particularly for pensioners) and their value in comparison with earnings has fallen as earnings have moved ahead of prices. They have never been fundamentally reviewed or re-based during that whole period (see Bradshaw and Lynes. 1995. for a full review of this topic). Similar changes in the way benefits are uprated have taken place in a number of other countries.

In Australia. there is currently considerable official interest in benefit levels: the Minister of Social Security has established a working group to review the levels of social security benefits and to determine how a bench-mark might be established to monitor adequacy. At present the Australian Department of Social Security monitors quarterly changes in the relative position of social security payments against the Henderson Poverty Line (HPL). The Henderson Poverty Line has its roots in the US Bureau of Labor Statistics Family Budget Standard. and although it is not formally endorsed by the Government it is widely used in Australia as a poverty measure. In fact, the level of benefit rates are currently related to average weekly earnings (AWE) of male employees. Thus, since 1990, the Government has agreed to pay pensions at 25 per cent of AWE (and in November 1993 it reached 25.5 per cent of AWE). Benefits for the unemployed are not covered by this agreement and in November 1993 they were 23.1 per cent of AWE. Benchmarks for child payments as a proportion of AWE were also set in 1987. Since these benchmarks were achieved in 1989. those payments have been uprated by the consumer price index. As average weekly earnings have been falling in real terms. the incomes of beneficiaries have been improving relative to earnings. This factor, as well as a number of small adjustments in benefit rates at different times, has led to improvements well above the rate of inflation. The Australian DSS has estimated that between. 1983 and 1992 the basic rate of pension increased by nearly 14 per cent in real terms, while support for a lone parent with one child aged 13 increased by 30 per cent.

Table 5.1 shows how benefit rates are set and uprated in the countries of the study. The sources of information are primarily the responses to the questionnaire sent to the official and academic informants for this study. More information is available in the individual country chapter of Volume Two. 


\begin{tabular}{|c|c|c|c|}
\hline Country & $\begin{array}{l}\text { Tier of government } \\
\text { respmnsible for setting } \\
\text { rates }\end{array}$ & $\begin{array}{l}\text { Method and period of } \\
\text { uprating }\end{array}$ & $\begin{array}{l}\text { Rate-setting mechanism and comparison } \\
\text { with other standards }\end{array}$ \\
\hline Australia & $\begin{array}{l}\text { National except in the } \\
\text { remote area allowance }\end{array}$ & $\begin{array}{l}\text { Twice per year fol basic } \\
\text { payments. Anmialiy for } \\
\text { most additional payments. } \\
\text { indexed by changes in the } \\
\text { consumer price index. }\end{array}$ & $\begin{array}{l}\text { Pension benchmarks were set nsing an } \\
\text { average weekly earnings index. In } 1990 \text {, } \\
25.5^{\prime} 1 \text { di of male average earnin } \mathrm{g}_{\mathrm{S}} \text { was set } \\
\text { as the level for the standard pension rate. } \\
\text { 3obsearchiNewstart rates are set at } 23 . \mathrm{P}>6 \\
\text { of AWE. Child benefits have been } \\
\text { indexed since } 1989 \text { and are } 16 .^{2}{ }^{\circ} \text { of of the } \\
\text { married pension rate for children under } 13 \\
\text { and } 21.2^{\circ}: 1 \text { for children } 13-15 \text {. }\end{array}$ \\
\hline Austria & $\begin{array}{l}\text { Provinces set benefit } \\
{ }_{\mathrm{g}} \text { uidelines, but district } \\
\text { authorities have discretion } \\
\text { to vary payments } \\
\text { according to their } \\
\text { assessment of individual } \\
\text { needs. National rates for } \\
\text { asylum seekers from ex- } \\
\text { Yugoslavia. }\end{array}$ & $\begin{array}{l}\text { Annually } \\
\text { Increased usually in line } \\
\text { with chan }{ }^{\text {es in pensions }} \\
\text { which are linked to } \\
\text { earnings. However, in } \\
\text { recent years the pension } \\
\text { has increased faster than } \\
\text { earnings and social } \\
\text { assistance has fallen } \\
\text { behind pensions. }\end{array}$ & $\begin{array}{l}\text { The standard rates for single people vary } \\
\text { between } 45 \text { and fir's of the lowest net } \\
\text { earnings and } 60 \text { to of the minimum } \\
\text { pensions }\end{array}$ \\
\hline Belgium & $\begin{array}{l}\text { National framework for all } \\
\text { the minimum benefits }\end{array}$ & $\begin{array}{l}\text { Annually } \\
\text { Automatically in line with } \\
\text { the retail price index, but } \\
\text { as a result of special } \\
\text { increases Minintex rates } \\
\text { have increased in real } \\
\text { terms since 1980, and } \\
\text { the gap between assistance } \\
\text { and insurance benefits has } \\
\text { narrowed. } \\
\text { In } 1994 \text { there was a new } \\
\text { index that excluded } \\
\text { cigarettes, alcohol and } \\
\text { petrol. This 'health index } \\
\text { produces lower levels of } \\
\text { uprating but in May } 1994 \\
\text { compensation was } \\
\text { included in the Rlinimex } \\
\text { uprating for sin gle people } \\
\text { and heads of households. }\end{array}$ & $\begin{array}{l}\text { IV9inimex rates (from 1975) were taken } \\
\text { from the al eady existing guaranteed } \\
\text { income for older people. Until } 1988 \text {. lone } \\
\text { parents were paid at the same level as } \\
\text { single people: from 1992. they received am } \\
\text { supplement- Now lone parents are treated } \\
\text { as couples (and thus receive about } 1.33 \\
\text { times tlae single person rate). } \\
\text { In } 1994 \text { the minimum Unemployment } \\
\text { Benefit rate was } 105 " 1,6 \text { of Niinimex. }\end{array}$ \\
\hline Canada & $\begin{array}{l}\text { Provinces and Territories. } \\
\text { are responsible for their } \\
\text { own benefit rates }\end{array}$ & $\begin{array}{l}\text { Annually } \\
\text { Generally cost of living } \\
\text { increases (by CPI or in } \\
\text { Quebec related to pension } \\
\text { indexation). but act hoc. } \\
\text { Since the recession several } \\
\text { provinces have frozen } \\
\text { benefits. }\end{array}$ & $\begin{array}{l}\text { Two provinces relate their upratings to a } \\
\text { benchmark standard. Though Statistics } \\
\text { Canada publish various low income } \\
\text { standards they do not directly influence } \\
\text { assistance rates. }\end{array}$ \\
\hline Denmark & $\begin{array}{l}\text { National rates. Social } \\
\text { workers at municipal level } \\
\text { have discretion over one- } \\
\text { off items. }\end{array}$ & $\begin{array}{l}\text { Annually } \\
\text { Since 1994, cash } \\
\text { assistance has been linked } \\
\text { to the level of } \\
\text { Unemployment Benefit, } \\
\text { which is related to average } \\
\text { earnings }\end{array}$ & $\begin{array}{l}\text { For parents, assistance rate is } 80 \text { kii of } \\
\text { nmaximum. Unemployment Benefit. For } \\
\text { others it was of maximum } \\
\text { Unemployment Benefit in } 1994 . . \text { rising t0 } \\
60^{\prime} Y \text { :, in } 1995 \text {. }\end{array}$ \\
\hline
\end{tabular}




\begin{tabular}{|c|c|c|c|}
\hline Country & $\begin{array}{l}\text { Tier of government } \\
\text { responsible for setting } \\
\text { rates }\end{array}$ & $\begin{array}{l}\text { Method and period of } \\
\text { uprating }\end{array}$ & $\begin{array}{l}\text { Rate-setting mechanism and comparison } \\
\text { with other standards }\end{array}$ \\
\hline France & $\begin{array}{l}\text { Social minima such as } \\
\text { RMI set nationally, along } \\
\text { with most housing benefits } \\
\text { and family allowances. } \\
\text { Aide Socials is local or } \\
\text { departmental responsibility }\end{array}$ & $\begin{array}{l}\text { RMI can be uprated twice } \\
\text { yearly in line with prices, } \\
\text { but not automatic }\end{array}$ & No information available \\
\hline Germany & $\begin{array}{l}\text { Lander set benefit rates, } \\
\text { within a lower and upper } \\
\text { national limit }\end{array}$ & $\begin{array}{l}\text { Generally every six } \\
\text { months } \\
\text { Social assistance is uprated } \\
\text { in line with price inflation, } \\
\text { but varies according to } \\
\text { political judgement }\end{array}$ & $\begin{array}{l}\text { Originally set in relation to a basket of } \\
\text { goods. Now set usin }{ }^{\mathrm{g}} \text { data on the } \\
\text { expenditure patterns of households in the } \\
\text { lower third of income distribution. } \\
\text { Variations between Lander are in practice } \\
\text { small }\end{array}$ \\
\hline Greece & $\begin{array}{l}\text { Minimum benefits set } \\
\text { nationally }\end{array}$ & $\begin{array}{l}\text { Ministerial or Presidential } \\
\text { decision. No statutory } \\
\text { period or basis. }\end{array}$ & No information available \\
\hline Iceland & $\begin{array}{l}\text { National government sets } \\
\text { minimum rates for } \\
\text { Financial Assistance, but } \\
\text { actual payment levels are } \\
\text { at discretion of } \\
\text { municipalities. } \\
\text { Pension supplements set } \\
\text { nationally. }\end{array}$ & $\begin{array}{l}\text { Uprating within six } \\
\text { months of a change in } \\
\text { reference insurance benefit }\end{array}$ & $\begin{array}{l}\text { Minimum rates set in line with those of } \\
\text { disability insurance, which are indexed to } \\
\text { wages } \\
\text { In recent years wages have not increased. } \\
\text { so neither have benefit rates }\end{array}$ \\
\hline Ireland & National & $\begin{array}{l}\text { Uprated annually; at least } \\
\text { in line with prices, but by } \\
\text { decision of Parliament }\end{array}$ & $\begin{array}{l}\text { By } 1994 \text { benefit rates had reached } 90 \text { '; of } \\
\text { the level recommended by the } \\
\text { Commission on Social Welfare in } 1986\end{array}$ \\
\hline Italy & $\begin{array}{l}\text { Social pensions and } \\
\text { disability pensions are set } \\
\text { nationally, but local } \\
\text { Llurinzo Vitale has no } \\
\text { national guidelines }\end{array}$ & $\begin{array}{l}\text { Uprated every } 6 \text { months } \\
\text { In line with the cost of } \\
\text { living index }\end{array}$ & $\begin{array}{l}\text { Social pension levels are about half of the } \\
\text { Italian poverty threshold and a quarter of } \\
\text { the minimum salary. Local assistance } \\
\text { benefits levels vary }{ }^{\text {gr }} \text { eatly by re }{ }^{\mathrm{g} i o n} \text { and } \\
\text { commune. }\end{array}$ \\
\hline Japan & $\begin{array}{l}\text { Rates are set nationally, } \\
\text { but within six geographical } \\
\text { bands }\end{array}$ & $\begin{array}{l}\text { Uprated annually. Indexed } \\
\text { to national average } \\
\text { consumption. }\end{array}$ & $\begin{array}{l}\text { Local authority areas are grouped into six } \\
\text { bands according to variation in the costs } \\
\text { of living. } \\
\text { Rates were improved in real terms during } \\
\text { the } 1980 \text { s, reaching about } 69 \text { of } \\
\text { average household consumption levels in } \\
\text { the early } 1980 \text { s. Since then they have } \\
\text { been indexed. }\end{array}$ \\
\hline Luxembourg & $\begin{array}{l}\text { Rates for both the .Revenu } \\
\text { illinimwn Garand and } \\
\text { categorical minima set } \\
\text { nationally }\end{array}$ & $\begin{array}{l}\text { Annually. by decision of } \\
\text { Parliament, in line with the } \\
\text { cost of living, according to } \\
\text { an index used for the } \\
\text { wages of civil servants, } \\
\text { Indexation can be varied } \\
\text { within } 25 \% \text { each way by } \\
\text { statutory order. }\end{array}$ & $\begin{array}{l}\text { Rates for RMG originally set in relation to } \\
\text { the structure of existin }{ }^{\mathrm{g}} \text { social security } \\
\text { benefits and minimum wages }\end{array}$ \\
\hline
\end{tabular}




\begin{tabular}{lll}
\hline Country & $\begin{array}{l}\text { Tier of government } \\
\text { responsible for setting } \\
\text { rates }\end{array}$ & $\begin{array}{l}\text { Method and period of } \\
\text { uprating }\end{array}$ \\
\hline Netherlands & $\begin{array}{l}\text { All minimum benefit rates } \\
\text { set nationally }\end{array}$ & $\begin{array}{l}\text { Uprating takes place twice } \\
\text { a year. in line with chan }{ }^{\mathrm{g}} \text { es } \\
\text { in the minimum wa }\end{array}$ \\
& $\begin{array}{l}\text { However, benefits were } \\
\text { frozen between 1984 and } \\
1990 \text { and a }\end{array}$ \\
& &
\end{tabular}

Rate-setting mechanism and comparison with other standards 1990 and $\mathrm{a}^{\mathrm{g}}$ ain in 1993.

\begin{tabular}{|c|c|c|c|}
\hline Nett Zealand & Set nationally & $\begin{array}{l}\text { Annually, by Parliament, } \\
\text { on the basis of income } \\
\text { requirements, prevailing } \\
\text { wa }^{\mathrm{g}} \text { es and fiscal } \\
\text { affordability. } \\
\text { Since 1991, indexed to } \\
\text { movements in prices subject } \\
\text { to a floor of of the } \\
\text { average } \mathrm{r}: \text { and a ceiling } \\
\text { of } 72 \quad \text { the average wage. }\end{array}$ & $\begin{array}{l}\text { From } 1972 \text { to } 1991 \text {, benefits were largely } \\
\text { based on the indexed value of } 80 \text { of a } \\
\text { prevailing } 1972 \text { low wage } \\
\text { In } 1991 \text {, the Government cut most } \\
\text { benefits in real terms by an average of } \\
1214 \sim ; ; i\end{array}$ \\
\hline Norway & $\begin{array}{l}\text { No national rates. } \\
\text { Local variation and } \\
\text { discretion. }\end{array}$ & $\begin{array}{l}\text { No uprating formula } \\
\text { Uprated locally by social } \\
\text { workers }\end{array}$ & $\begin{array}{l}\text { Local scale rates interpreted by social } \\
\text { workers } \\
\text { No data on link with wages/prices }\end{array}$ \\
\hline Spain & $\begin{array}{l}\text { Determined by each } \\
\text { autonomous region }\end{array}$ & No information & No information \\
\hline Sweden & $\begin{array}{l}\text { Nationally recommended } \\
\text { standard rates } \\
\text { Local variation }\end{array}$ & $\begin{array}{l}\text { Standards uprated } \\
\text { annually_in line with } \\
\text { prices and consumer } \\
\text { patterns }\end{array}$ & $\begin{array}{l}\text { Since } 1985 \text {. monetary standard was based } \\
\text { on items included in the household budget } \\
\text { drawn up by the National Board for } \\
\text { Consumer Policies } \\
\text { Index used for assistance produces lower } \\
\text { uprating than that for insurance benefits }\end{array}$ \\
\hline Switzerland & $\begin{array}{l}\text { Guideline norms set by } \\
\text { national institute (CSIAP), } \\
\text { but actual rates paid can } \\
\text { vary both below and above } \\
\text { norms according to Canton } \\
\text { and commune } \\
\text { Supplementary pension } \\
\text { rates set nationally }\end{array}$ & Norms uprated annually & $\begin{array}{l}\text { CSIAP guidelines are based on a budget } \\
\text { standard. } 1988 \text { norms were similar to } \\
\text { minimum, income-related pension level } \\
\text { and below full guaranteed insurance } \\
\text { pension level. }\end{array}$ \\
\hline Turkey & Rates set nationally & Every three months & $\begin{array}{l}\text { Based on a formula which is used to } \\
\text { determine wa }{ }^{\mathrm{g}} \text { es for civil servants } \\
\text { Considered to be very low even in relation } \\
\text { to earnings }\end{array}$ \\
\hline
\end{tabular}


Table 5.1: Median's s for setting and uprating social assistance benefits 'contd.)

\begin{tabular}{|c|c|c|c|}
\hline Countrv & $\begin{array}{l}\text { Tier of government } \\
\text { responsible for setting } \\
\text { rates }\end{array}$ & $\begin{array}{l}\text { Method and period of } \\
\text { uprating }\end{array}$ & $\begin{array}{l}\text { Rate-setting mechanism and comparison } \\
\text { with other standards }\end{array}$ \\
\hline USA & $\begin{array}{l}\text { Supplemental Security } \\
\text { Income determined } \\
\text { federally and } \\
\text { supplemented by some } \\
\text { states. } \\
\text { Food Stamps set federally. } \\
\text { Aid to Families with } \\
\text { Dependent Children set by } \\
\text { states within federal } \\
\text { guidelines. } \\
\text { General Assistance is } \\
\text { optional scheme with rates } \\
\text { set by state. }\end{array}$ & $\begin{array}{l}\text { SS" adjusted annually } \\
\text { using costs of living } \\
\text { standards produced by } \\
\text { Bureau of Labor Statistics. } \\
\text { Food Stamps adjusted } \\
\text { annually according to } \\
\text { changes in the costs of a } \\
\text { 'thrifty' food plan. } \\
\text { AFDC and GA uprated at } \\
\text { the discretion of states. }\end{array}$ & $\begin{array}{l}\text { For SS.i, the } 1993 \text { individual rase s: as set } \\
\text { at } 75 \% \text { of poverty threshold t.. when } \\
\text { Food Stamps are included and 10:f: fat a } \\
\text { couple). Food Stam }{ }^{\mathrm{p}} \mathrm{s} \text { based on thrifty } \\
\text { food budgets. }\end{array}$ \\
\hline
\end{tabular}

\subsection{Debates about poverty and the level of benefits}

It is not the intention here to discuss. in detail. research on the relative levels of poverty in OECD countries. Some of the main. recent work in this area was referred to in Chapter One. along with the difficulties involved in such a comparison. The aim is rather to illustrate the range of issues which are or have recently been on the policy agenda concerning the effectiveness of minimum income schemes and social assistance in dealing with poverty. The level of consistent information available was limited_however, and this section is necessarily brief. We begin by discussing the terms of the debate.

How much poverty is debated as an issue varies. not surprisingly, between countries in the OECD. Factors which seem to influence the level of debate include the extent to which recent economic problems have resulted in noticeable increases in deprivation, and the effectiveness of political parties or lobby groups at drawing public attention to the issues. There is not necessarily a correlation. however, between intensity of debates on poverty and actual levels of either absolute poverty or inequality, in so far as these can be determined. There are, nevertheless, some common themes or concerns.

First, in many countries, widespread concern about poverty appears to have been a relatively recent development. Informants in several countries. including Canada. Germany and Ireland_referred to the 'rediscovery' of poverty in the 1970s. and to the influence of British and other English-language research in suggesting the persistence of poverty amongst increasing affluence in developed countries. Within the European Union countries. in particular, the concept of 'new' poverty has grown out of comparative analyses of the effects of the European-wide recession of the late 1980s, and the combination of social and demographic change and labour market restructuring which has been a common feature across both the Union and the OECD area as a whole (see Chapter One).

This poverty is regarded as new partly because of the changed conditions which have given rise to it and partly because of the identification of certain population groups amongst whom poverty has become more prevalent, including young people, lone parents, older women, and families with children where the main earner is unemployed or in insecure work with low pay. Hotyever. emphasis on economic 'poverty' as a concept is often regarded as too narrow an approach and 
the alternative term 'social exclusion' is widely regarded_in European debate. as capturing more accurately the broader sense of deprivation which may be experienced as a result of inability to participate in the mainstream life of the citizen. The concept of 'social exclusion' also implies that action to counter the problem should be seen as encompassing more than simply cash income maintenance -- a view which accords with the more social work-oriented and rehabilitative approaches to social assistance of the Nordic and some northern European states. Exclusion is, however, a concept which is even harder to measure than poverty, and the importance of a level of cash income security as a basis for combating it has been acknowledged in the European Commission's Draft Recommendation on guaranteeing sufficient resources (Commission of the European Communities. 1991).

Discussions within the Union about ensuring minimum incomes in the context of the Single Market have stimulated debate in a number of countries not only those of the EU itself. In the countries of southern Europe in particular Portugal and Spain -- where problems of poverty have long been recognised, debate has focused, to varying degrees, on developing guaranteed minimum incomes in line with those of the European partners. Discussions have tended to founder, however. even where there has been widespread agreement on the nature of the problem, on the economic practicalities of greater provision (Bruto da Costa, 1994a) or on broader difficulties of social modernisation (Petmesidou. 1991). In spite of the considerable poverty which has existed in Greece (Karagiorgas et al., 1990; Deleeck et $a(.$. 1991) however, there has been relatively little public debate about the possibility of creating a guaranteed minimum income, or about poverty as such (Tsakoglou, 1993). although the particular problems facing older people have been highlighted in a number of reports. In Italy too, while the austerity measures of the Berlusconi Government. which included reductions in pension rights, provoked strong public opposition, there is little sign of any debate on minimum incomes. Indeed debate on social policy as a whole tends, in recent years. to have been submer ${ }^{\mathrm{g}}$ ed in the political and juridical crises of the Italian state.

The particular domestic histories and politics of some countries have also tended to inhibit the institution of uniform national assistance schemes. Spain, for example. has reacted against the over-centralised state of the Franco era by increasingly devolving powers to the autonomous regions and localities, including responsibility for income maintenance. As a result, some researchers argue, there is a lack of adequate national data on poverty. and the legislative autonomy of the regions is producing territorial inequalities in minimum income protection (Ayala. 1994).

There is evidence that other non-EU members have also been influenced in recent years by debate within the Union. particularly countries, like Austria. which were candidates for membership. There was little official recognition that poverty might exist in Austria until recently. Now, however, there is growing debate about both the levels of assistance, which tend to fall below EU 'poverty lines', and about the possible shortcomings of the localised and discretionary allocation of benefits. although Pfeil (1994) has noted that the sub-text for this debate is often the distribution of power and resources between central government and the provinces. In Switzerland too. which is generally thought of as having only minimal poverty, there has been some debate about the effectiveness of their comparatively generous, but highly individualised, assistance scheme in preventing the development of 'new forms of poverty.

The terms of debate have been somewhat different in the Scandinavian countries. There. poverty began to be talked about again in the late 1980s. mainly as a result of growing unemployment, but concern has been largely about inequality rather than poverty as such. Although there have been disputes in Denmark and Sweden about the extent of poverty, concern has focused particularly on the small groups of very poor people, or those experiencing forms of multiple deprivation or complex social problems which require social intervention other than simply through cash benefits. However, in Finland and Norway especially, but in other 
social work-oriented regimes too. expanding caseloads have been leading to conflict between the traditional caseworker role of social welfare officers and the demands of cash benefit delivery. If claimant numbers continue to grow, this question is likely to become more acute and may lead these countries to a greater standardisation of benefit levels and regulations. In general, debate on social assistance in the Nordic countries has tended to focus less on poverty relief as such and more on aspects of delivery of benefits. Thus in both Norway and Sweden. arguments have centred on the advantages of uniform national rates and regulation versus local and individualised discretion, and on problems of administration, as well as on the division of financial responsibility between the local and central state.

A further theme which has been particularly salient in the USA. and to a lesser extent in the UK, has been that of benefit dependency and work incentives. While concern about the consequences of' long-term dependency on social assistance. both to individuals and to the economy, are common to most countries in the OECD. this debate seems especially potent in the LISA and has been growing in the UK. As Chapter Two showed, both are countries where assistance benefits are central to their systems of social protection. In the USA particularly, anxieties about the social consequences of the emergence of a deprived 'underclass' of welfare recipients has in recent years fuelled much of the policy debate on social assistance. This debate has had some resonance in the UK too, although questions concerning the generosity and costs of means-tested benefits have perhaps been more prominent. The extent to which receipt of social assistance can be seen as synonymous with poverty in the UK is a matter of continuing debate.

While the underclass debate also has some resonance in the other English-speaking countries, and the work incentive debate has been a central element of the Canadian government's recent review of income maintenance policy, the key issues are currently rather different in Australia and New Zealand. The Labor government in Australia has been engaged for some years in a high profile 'Social Justice Strategy'. of which income support benefits are a key element. This has involved concentrating resources on lower income families in particular, in order to combat child poverty, through a combination of increased payments and tighter eligibility criteria. This was also one of the key aims of the UK benefit reforms in 1988, which established Family Credit as an important assistance-linked earnings supplement intended to reinforce the work incentive elements of the benefit structure. One way in which Australian Government. strategy has differed from that of the UK, however, has been in the establishment of an official working party to research benchmarks of adequacy for benefit payments. These targeting strategies in all three countries have not been without their critics, but there is general agreement that the social and economic policies delivered under the Government-trade union Accord in Australia have had some substantial success in reducing family poverty. By contrast, debate on poverty in New Zealand has been revived as a result of policies of economic liberalisation, involving higher unemployment, direct and substantial reductions in some benefits, and an expansion of charges for services.

We have said that the extent of public debate about poverty and benefits is not necessarily correlated with the level of poverty itself. Turkey, for example, has the lowest per capita income among the OECD countries, but, as far as we have been able to ascertain there is relatively little debate specifically about social security provision. Japan. on the other hand, is one of the wealthiest countries, but also has little public debate on social assistance. The existence and achievements of voluntary organisations and campaign groups clearly represent one factor in this equation, and the next section looks at the evidence obtained on their role in the countries of the study.

The role o/' non-governmental organisations and 'poverty lobbies'

Although the information available to the research team is neither detailed nor consistent across countries, it does appear to suggest that the existence of organised 
campaigns and lobby groups working around poverty generally, or representing particular population groups or claimants, is an important element in whether poverty and social assistance are matters of public debate. This is not surprising in itself, though it is noticeable that such poverty lobbies are judged by our national informants in a number of countries to have had only limited influence on actual policy decisions. However_such influence is not always easy to determine. To some extent the existence of organisations active around issues of social security depends on different national policies towards the voluntary sector. In the U.K and Canada. for example, which have some of the most developed networks of organisations working in service provision, welfare rights and campaigning around social security issues. many agencies are reliant on public funding to support their activities. Both the UK and the US experience tends to suggests that welfare rights activity is to some extent symbiotic with the structures of social security. In both countries welfare rights groups have used tactics of exploiting the opportunities available in highly regulated systems to advance the interests of their clients. There were fears, for example, that the simplification of benefits introduced in the UK in 1988, and the re-introduction of officer discretion into decisions on exceptional needs would spell the end of meaningful welfare rights activity. In practice this has not happened. but the scope and focus of welfare rights has had to change. Similar processes have also been observed in the USA.

The churches and denominational charities are also active in this field in the UK and other northern European countries, including Belgium. through the Quart Manila and Welzijns_org organisations, and the Netherlands through De Arnie Kant_ but their role in service provision is limited. In the Catholic south of Europe, however, the church, through the international Caritas organisation and other national equivalents. is often the key non-governmental body, playing a role both in the provision of services and support and in policy debates. In some countries, including Spain, the line between public and private provision is less distinct than in other countries, with Caritas and other or ${ }^{\mathrm{g}}$ anisations receiving public funding to support the distribution of help in both cash and kind, and discretionary assessments of need being carried out. jointly by local social workers and the charity. Churches are also playing a key role in New Zealand. They have formed the core of a growing opposition to the liberal economic policies of the current government, producing a series of reports on poverty and establishing food banks for people facing hardship as a result of unemployment or benefit reductions.

It is noticeable that campaigning and lobbying around poverty and social assistance appears. generally, to be less organised both in countries with lower levels of provision and those with localised and discretionary schemes. It may be that the nature of provision in such countries, being more personalised and individual, is more difficult to organise campaigns around than in those with more visible, national schemes. On the other hand. locally-run assistance schemes may be more amenable to individual advocacy and casework. It is also likely that voluntary activity in these countries is more localised and thus less accessible to researchers.

Debates about adequacy of assistance payments

Having surveyed the debates on poverty and social assistance, and the role of poverty lobbies, we now turn to specific views on the adequacy of benefit levels. Clearly adequacy is to a considerable extent a subjective question and the extent of research both on measures of adequacy and on views and attitudes varies considerably across countries. All we are able to do here is to reflect very briefly the key points coming through from national informants' summaries of debates in their respective countries. These points are summarised in Table 5.2 and further discussion can be found in the individual country chapters in Volume Two. 
Table 5.2: Views on the adequacy of social assistance

\begin{tabular}{|c|c|}
\hline Country- & Views on the adequacy of social assistance \\
\hline Australia & $\begin{array}{l}\text { Australian income support programmes are intended to promote equity in the way " } \\
\text { economic resources are distributed and equality of social and economic rights, will } \\
\text { adequacy a key objective. The DSS is currently researching and developing a } \\
\text { framework for a benchmark of adequacy for basic payments. Although increased } \\
\text { tar }^{\mathrm{g}} \text { eting has been criticised. it is generally accepted that benefit levels have been } \\
\text { improved for most categories of client. }\end{array}$ \\
\hline Austria & $\begin{array}{l}\text { In Austria social assistance only plays a minor role in combating poverty and only } \\
\text { absorbs } 03^{\prime} \% \text {; of social security expenditure. Standard rates for assistance for single } \\
\text { people are substantially below both minimum pension Levels and the lowest net } \\
\text { ages. The discretionary powers exercised by the provinces have led to questions } \\
\text { about whether social assistance is adequate to promote a minimum standard of }\end{array}$ \\
\hline Belgium & $\begin{array}{l}\text { In spite of the relative increase in benefit levels compared to insurance belle s. } \\
\text { commentators ar }{ }^{g_{u}} \text { e that the Minimex is still insufficient to raise all people out of } \\
\text { poverty. It is not viewed by social welfare campaigners as adequate to promote a } \\
\text { minimum standard of living. }\end{array}$ \\
\hline Canada & $\begin{array}{l}\text { Social assistance rates iu most provinces appear to be below a number of poverty } \\
\text { standards, including 'baskets of goods' measures and the semi-official low Income } \\
\text { Cut-Off measures produced by Statistics Canada. This is particularly the case for } \\
\text { single 'employables'. The Government argues that the rates alone cannot be } \\
\text { compared with the LICOs because they are not comprehensive and do not include } \\
\text { all possible benefit payments from provinces and municipalities. }\end{array}$ \\
\hline Denmark & $\begin{array}{l}\text { Whether or not benefit levels are adequate has been a matter for debate: a person } \\
\text { may he fed. clothed, housed on social assistance. but there is little left over for any } \\
\text { other expenses }\end{array}$ \\
\hline $\mathrm{F}$ and & $\begin{array}{l}\text { The Consumer Research Unit has compared benefit rates to a basket of goods and } \\
\text { judged them adequate. Surveys suggest the majority of' the public also believe them } \\
\text { to be sufficient. as opposed to recipients (and many officials) who do not. } \\
\text { Assistance rates have been found in comparative studies to be lower in Finland } \\
\text { than in the other Nordic countries. }\end{array}$ \\
\hline France & There has been little or no research into the adequacy of assistance payments \\
\hline Germany & $\begin{array}{l}\text { The Federal government believes assistance levels to be adequate and that problem } \\
\text { only arise for tho'.:: a ho do not take it up, but this view is disputed by many social } \\
\text { researchers in }{ }_{-} ; \text {i ..tv }\end{array}$ \\
\hline Greece & $\begin{array}{l}\text { Social assistance in Greece is very limited and benefits are widely re }{ }^{g} \text { arded as } \\
\text { inadequate. In } 1992 \text { payments for an elderly person without insurance cover } \\
\text { represented only } 11 \text { per cent of the national minimum wage. }\end{array}$ \\
\hline Iceland & $\begin{array}{l}\text { Surveys } \mathrm{su}^{\mathrm{g}} \text { gest that the majority of the public does not consider assistance rate } \\
\text { sufficient to live on. but there is no broad support for increases. Rather. public } \\
\text { pressure is on Government to reform pay policies and combat unemployment. }\end{array}$ \\
\hline Ireland & $\begin{array}{l}\text { The Combat Poverty Agency (a statutory body) holds the view that social } \\
\text { assistance rates are inadequate and in spite of improvements do not meet the } \\
\text { minimal adequacy standards set by the Commission on Social Welfare }\end{array}$ \\
\hline Italy & $\begin{array}{l}\text { Hard to gauge evidence on adequacy due to local variation, regional divides in the } \\
\text { levels between North and South, and high levels of discretion. Little systematic } \\
\text { evidence on public opinion. }\end{array}$ \\
\hline Japan & $\begin{array}{l}\text { Benefits increased in real terms in the } 1980 \text { s and the official view is that benefits } \\
\text { are adequate. There is little evidence of debate on the subject. }\end{array}$ \\
\hline Luxembourg & $\begin{array}{l}\text { Benefits are relatively high, leading to some incentive problems. Generally regarded } \\
\text { as adequate. though some restrictions apply to the availability of the RAG. }\end{array}$ \\
\hline Netherlands & $\begin{array}{l}\text { Social assistance is generally regarded as sufficient to bye on for a short period, } \\
\text { though longer periods can result in the incurring of debts }\end{array}$ \\
\hline New Zealand & $\begin{array}{l}\text { Until the } 1991 \text { reductions, benefits were broadly viewed as adequate for most } \\
\text { family types. The changes since } 1991 \text { have been criticised for leading to substantial } \\
\text { hardship. Some evidence comes from the growth in food banks. Reductions in } \\
\text { housing support are also said to have led to a growth in homelessness and } \\
\text { inadequate housing. }\end{array}$ \\
\hline Norway & $\begin{array}{l}\text { Local variation and individualised assessments mean that there is little evidence on } \\
\text { adequacy }\end{array}$ \\
\hline
\end{tabular}




\begin{tabular}{|c|c|}
\hline Country $=$ & $V$ iews on the adequacy of social assistance \\
\hline Portugal & $\begin{array}{l}\text { Social assistance is very low in Portugal compared to earnings. This means that } \\
\text { poverty and work traps are unlikely to develop, but benefits are not widely } \\
\text { regarded as sufficient to live on by themselves. }\end{array}$ \\
\hline Spain & $\begin{array}{l}\text { A major issue for Spain is territorial inequality produced through establishment of } \\
\text { local minimum income schemes in } 1988 \text {. Such information as is available on the } \\
\mathrm{re}_{\text {ional schemes suggest average payments are well below estimates of a poverty }} \\
\text { line. }\end{array}$ \\
\hline Sweden & $\begin{array}{l}\text { Local variation i t rates makes it hard to assess benefit adequacy } \mathrm{n} \text { relation tc } \\
\mathrm{wa}_{\mathrm{g}} \mathrm{es}_{\text {, benefits are relatively low. }}\end{array}$ \\
\hline Switzerland & $\begin{array}{l}\text { The absence of national rates leads to geographical inequality in treatment. The } \\
\text { individual nature of assessments also makes adequacy hard to gauge. Benefit } \\
\text { norms, however, are relatively high. }\end{array}$ \\
\hline "Turkey & $\begin{array}{l}\text { The system in Turkey is still being developed. so there is no evidence concerning } \\
\text { adequacy, but assistance benefits are considered to be low even in relation to per } \\
\text { capita income }\end{array}$ \\
\hline UK & $\begin{array}{l}\text { The question of the adequacy of Income Support rates is a matter of ongoing } \\
\text { debate in the UK. Apart from the level of benefit itself, the adequacy question has } \\
\text { also been raised in connection with the (relatively few) people with multiple } \\
\text { deductions from Income Support (such as for debts, fines and repayments of social } \\
\text { fund loans). Concerns about the discretionary role of the Social Fund have also } \\
\text { been linked to the issue of the adequacy of Income Support rates_ }\end{array}$ \\
\hline 'USA & $\begin{array}{l}\text { When measured against the official poverty line most assistance benefits in the } \\
\text { USA leave people below this level. In } 1993 \text { the maximum benefit for a single } \\
\text { person was } 86 \% \text { of the poverty line. }\end{array}$ \\
\hline
\end{tabular}

In Australia. as we have seen, the issue of adequacy is one with which the Government is currently preoccupied. It has established a working party to review the adequacy of benefits and set benchmarks for them. In the UK too. although Governments have not felt it practicable to establish an official poverty line, there has nevertheless been continuing concern amon ${ }^{g}$ welfare rights organisations. academic researchers and people working with low-income families about the adequacy of the levels of Income Support. In other countries. the degree of debate about adequacy reflects to some extent the salience of social assistance in the social security system. In those countries where social assistance is more important. it appears that there is more debate about adequacy and more information on the subject. These countries include, as well as Australia and the UK, Ireland. New Zealand and the USA. In those countries where social assistance levels are highly variable or locally determined, there is naturally more difficulty in examining the issue of adequacy.

\subsection{Take-up of means-tested benefits}

Whether or not benefit rates are considered to be sufficient to live on. means-tested benefits are only likely to be effective against poverty or other problems if people who are entitled to claim them do so. As was pointed out in Chapter One, it has long been a criticism of means-tested benefits that take-up is often low compared to that for other types of benefit. van Oorschot, who has carried out perhaps the most extensive studies to date of take-up in a comparative context (1991 and 1995: van Oorschot and Schell, 1991). has suggested that, with the exception of Britain, the non take-up of social security benefits has been a particularly neglected topic in the welfare state literature.. This observation was supported in the information provided by national informants for this study. Less than a quarter of the countries were able to provide any recent estimates of take-up and the basis of these was not always clear.

Official estimates of take-up in Australia suggest a relatively high level of take-up for most benefits, ranging from 71 per cent for the Sole Parent Pension, to 100 per cent for Family Payments (though only 29 per cent for the Service Disability Pension). However, most of the estimates provided are of coverage of the known 
population group and take no account of those who might be ineli $\mathrm{g}_{\mathrm{ible}}$ because of excess resources. In this light, the Australian estimates look even higher a fact which may be partly explained by virtually all benefits being resource-tested in some way.

In Germany, it was suggested that take-up was controversial. Studies in the mid1980s pointed to an increase for Sonioihilfe from an estimated 50 per cent in the 1970s to around 70 per cent. It is not clear why such an increase should have taken place, but one possibility is that growth in claiming by lone parents and younger people may have led to better understanding of $\mathrm{ri}^{\mathrm{g}} \mathrm{hts}$ and less reluctance to claim.

Japan appears to have had a low take-up rate, at least in the early 1980s (Sohara, $1985)$, but there are no more recent estimates and the present situation is unknown.

An official estimate from Luxembourg put take-up for the Rerenit Minimum (iciranti at only around 50 per cent surprising perhaps given the relatively high level of benefits. However. the RMG is generally received as a supplement to some other source of income and it may be that small entitlements are less commonly taken up. This is a feature of take-up which has been observed in the extensive research carried out in the UK. both by Government and by independent researchers (see. for example. Kerr. 1983; Fry and Stark. 1987: Craig, 1991; Marsh and McKay. 1993; Department of Social Security, 1994; Corden. 1995). Official estimates put take-up of Income Support in 1992 at 77-87 per cent of expenditure, depending on household type, and most of the amounts not claimed are estimated to be fairly small. Family Credit performs somewhat less well in this respect, partly perhaps because it again acts as a top-up for earnings rather than as a subsistence benefit. The best estimate for 1992 was a take-up rate of around 73 per cent (expenditure) and the rate appears to have improved since the benefit was introduced in 1988.

Informants from a number of other countries, including Austria, Belgium. France. the Netherlands and the Nordic countries all suggested that there were likely to be some take-up problems with the minimum benefits in their countries, but that the question had not been extensively researched. Some studies did, however. point to various specific problems such as non-receipt of children's additions by families receiving the Minimex in Belgium, and low take-up of benefits for disabled children in France.

The Nordic social assistance schemes present particular difficulties in discussing take-up, partly because of local variations in benefit levels in some of the countries, but also because of certain specific features of the conditions of entitlement. In Sweden, for example, it is estimated that there are a large number of working families with one wage earner who are in theory eligible for social assistance to supplement their earnings. Many do not claim, however, because if they did the availability for work test would require the unemployed spouse to seek work. Take-up is also particularly difficult to assess in other countries with highly discretionary systems. such as Austria and Switzerland.

van Oorschot (1995) has concluded that non-take-up is influenced by factors at three levels: first the way benefits are designed, secondly the way benefits are administered: and thirdly the way potential claimants respond. Non-take-up is more likely to be a problem in means-tested benefit systems, in schemes that have a density of complex rules, have vague criteria for entitlement, are aimed at social groups which are the subject of prejudice, supplement other sources of income and leave the initiative in taking up benefits to the claimant. These characteristics exist in many of the social assistance schemes in this study.

Many of the national informants also suggested that claiming social assistance continued to be stigmatised to some degree, even where the existence of the benefits had wide levels of support and legitimacy. Stigma, of course, is hard to measure and the information available is impressionistic. but examples were given 
particularly from countries where local and discretionary systems combine with small numbers of claimants. In these circumstances it is possible for individuals or particular groups to be singled out as welfare recipients_and for them to become the subject of prejudicial public attitudes. By contrast. receipt of benefits in countries like Australia and New Zealand seems relatively lacking in stigma, although even in these countries being able bodied and unemployed can attract residual prejudice.

\subsection{Conclusion}

This chapter has brought together information on how benefit rates are set and uprated, debates about poverty and the adequacy of assistance benefits, and takeup of means-tested benefits in the OECD countries. While in general there has been increasing concern about poverty in many of the countries in the study. the terms of these debates have often been very specific to the particular circumstances of individual countries. Where assistance schemes are minor elements of much more developed social security systems, debates have often focused on elements other than assistance. In a few countries, levels of assistance benefits seem fairly widely agreed to be adequate. at least in the short term. Even where they are not seen as sufficient, there is often no consensus for raising them, either because of concerns about expenditure or work incentives or because extra money is not necessarily seen as the answer to social exclusion. There also seems to be relatively little serious concern in most countries about whether assistance schemes are taken up by all those entitled. The limited evidence available suggests that take-up tends to be lower in places where benefits are aimed at small and marginalised groups in society. and generally higher where the use of assistance is more mainstream.

The next chapter focuses on the empirical data collected to compare the relative values of benefits across countries by using model family ty-pes. 


\section{Chapter 6 The Level and Structure of Social Assistance Payments}

\subsection{Introduction}

This chapter compares the level and structure of social assistance payments in the countries in the study. The analysis is based on the data provided by the national informants on the impact of different benefit 'packages' on a series of model families in specified. near-identical circumstances. The chapter starts by explaining the methods and assumptions used. It then compares the levels of the different social assistance packages and shows how they vary with the characteristics of the claimant unit (the implied equivalence scale). An overall ranking of the level of social assistance is presented and comparisons are made of the level of net disposable incomes of some of the same families if they were receiving insurance benefits or average earnings, along with any in-work benefits available. These data are used further in Chapter Seven to compare benefit replacement ratios and investigate incentive structures.

Even in the few earlier comparative studies of social assistance referred to in the introduction to this volume, there has never been an attempt to compare the level of income provided through social assistance. This may be because social assistance benefits are not very salient in many countries. The problems of defining the scope of social assistance, which have been discussed elsewhere in this volume, also make such comparisons difficult. Perhaps the main reason why such a comparison has not previously been attempted on this scale is the difficulty of comparing like with like. The limitations of the analysis which stern from this difficulty are spelled out below.

\subsection{Methods}

In the study of child benefit packages in 15 countries carried out at the University of York by Bradshaw et a/. (1993a), data were collected on the social assistance benefits paid to model families in a ' worst ase $^{\circ}$ situation. invariably long-term unemployed families no longer entitled to social insurance benefits. Information on three other countries was subsequently added and preliminary evidence on the level of social assistance in 18 countries was compared in Bradshaw (1995).

It was found in the previous research that. by using national informants to simulate the impact of social policies on a selection of model families, comparable and reliable data on the level and structure of benefit packages could be obtained. These techniques have been used again in this research and indeed we have been able to use some of the data collected in the previous studies. However, there were a number of changes.

First. this study covers more countries than the original 15 (subsequently 18). In this study, data were collected on 23 OECD countries (unfortunately it was not possible to obtain data for Turkey, and those on Iceland and Italy are incomplete). Also, because of the degree of variation within the USA, four separate States have been covered. Secondly, because the focus of the previous study was families with children, claimants over retirement age were not covered. However, as retirement pensioners are, in some countries, an important group receiving social assistance, they have been included in this study. The earlier study was not directly concerned with contributory insurance benefits, but in order to compare levels of insurance benefits with those of assistance, insurance data were collected for this study. These additions to the coverage had. however, to be achieved at the costs of reducing the 
variety of family types on which data were collected. The comparison was therefore limited to the following family types:

1. A single person aged 17

2. A single person aged 35

3. A single retired person aged 68

4. A couple both aged 35 (couples were assumed to be married)

5. A retired couple both aged 68

6. A couple aged 35 with one child under three (two years and eleven months ie. pre-school age in all countries)

7. A couple aged 35 with one school aged child (seven years)

8. A couple with two children, aged seven and 14

9. A lone parent \{female. separated or divorced, not widowed) with one pre-school child

10. A lone parent (female, separated or divorced. not widowed) with one school age child (aged seven).

This selection of family types is inevitably somewhat arbitrary. They were chosen to illustrate the range of types of families that might be dependent on social assistance benefits. They were also chosen to allow comparison of the level of benefits paid to different types of claimant, including single unemployed people of different ages, couples - of working age and retired - and families of different types with different numbers and ages of children. Ideally, other family types receiving social assistance would have been included, such as larger families. or people with disabilities and other special needs, but a line had to be drawn somewhere. It also has to be recognised that some of these family types are more or less common in different countries, and that the likelihood of different family types being in receipt of assistance also varies between countries. In Chapter Two, the characteristics of social assistance recipients in different countries were compared. However, the data available for many countries are limited and often not easily comparable. Nevertheless, it is clear that the modal or typical social assistance recipient varies between countries. In the Nordic countries, for example, about two-thirds of social assistance recipients are young and single. In the UK. they are much more evenly spread across family types, including unemployed families with children, lone parents and older people.

The chosen examples are also all 'nuclear" families. The complexity of attempting to model the policy framework for the presence of other adults in the household, or for other wider family and household obli ${ }^{g}$ ations, arguably outweighs the possible advantages. Specifying that all couples are married also means that differences in the treatment of cohabiting couples cannot be analysed. Finally, the assumption has to be that resources are shared within families in a similar way across the countries compared. There is sufficient data on inequalities in withinhousehold resource distribution in certain countries to make this assumption highly questionable, but since the purpose of the analysis is to examine the structural effect of benefit policies. it can be argued that the distribution of resource consumption within families is a separate issue. It should be noted, however, that different countries' policy approaches to this question are reflected in areas such as individual taxation. individualisation or splitting of benefits and choices about to whom benefits for children are paid.

Simulating the impact of national polices on the model families requires a series of detailed specifications, and a number of choices have to be made which are not always entirely satisfactory. The following sections outline the choices made for this exercise, starting with the specification of the income and benefit packages which were assumed to accrue to the model families. There were three income packages. as follows: 


\section{Social A ssistance}

This was the package of benefits that would be received by the model families on social assistance, and was the main focus of the research. For the families of working age, the adults were assumed to have been unemployed for long enough not to be entitled to any contributory unemployment benefits for, in the case of the 17 year old, not to have a contributory record). In the case of the 68 year olds. it was assumed that they were out of the workforce and did not have contributory records sufficient for any insurance-based pension. Even where minimum. incometested pensions were available they were not counted if they required a record of insurance contribution. It was assumed that none of the social assistance families had any income from earnings - they were either retired. receiving the assistance paid to the long-term unemployed, or the assistance paid to lone parents. This latter assumption means that the analysis cannot fully represent the experience of those countries where social assistance, or other means-tested benefits. are commonly paid as a supplement to low or part-time earnings.

\section{Social Insurance}

This was the package of benefits paid to some of the same families if they were receiving contributory or insurance benefits. It was assumed that none of the social insurance families had any income from earnings. The pensioners were assumed to be receiving the state pension payable to someone who had worked since the age of 21 , with a full record of contributions based on national average earnings throughout their working lives. Obviously this is a simplification of real experience in many countries where pension entitlements have changed in the last 40 or so years. and does not reflect the real earnings trajectory of most workers. Occupational pensions were not included unless they were compulsory and underwritten by the state. Again, this assumption leads to the under-estimation of pensioners incomes in those countries (such as the UK) where occupational pensions are commonly payable on top of the state schemes. In the ease of couples. it was assumed that the female partner had not been employed (again an unlikely assumption in some countries). The adults of working age, includin ${ }^{g}$ the lone parent, were assumed to have been unemployed for three months_ and receiving the full unemployment benefit payable on the basis of maximum contributions to someone who had previously been continuously employed at national average earnings. Again. in the case of couples, the female partner was assumed not to have been in employment.

In order to be able to calculate the value of special support going to lone parents. compared to couples with children or single people without children, the lone parents (while specified to be mothers) were assumed to have been receiving average male earnings. Clearly this would often be unrealistic, but it was necessary in order to avoid confusing the structural effects of tax/benefit policies with wage differentials by sex.

\section{The working case}

This estimated the packa ${ }^{\mathrm{g}} \mathrm{e}$ of benefits paid. in addition to earnings. to some of the same households if they were working and receiving average male earnings in each country. These data were required in order to compare the level of social assistance with net disposable income in work, and to explore replacement rates and marginal tax rates. The working families, including the lone parents, were assumed to have one earner working full-time for national average male earnings.

There are no completely satisfactory and up-to-date data on earnings for all the countries in the study and it was necessary to use a standard methodology to develop comparable estimates. For comparability, this replicated the methods used in Bradshaw et at. ( 993a). OECD estimates in The 1989 Tax-Benefit Position of Production Workers (1990) were used as the base. These give the average gross earnings of all full-time production workers in the manufacturing sector in each country. They were updated to May 1992 using the index of hourly earnings of 
production workers in the manufacturing sector given in the OECD publication Main Economic Indicators. National informants were asked to check these $\mathrm{fi}^{\mathrm{g}}$ ures against national sources and in a few cases adjustments were made to the OECD figures.

The earnings levels derived using this method are summarised in national currencies and purchasing power parity terms (see discussion of these in Chapter One) in Table A6.1 in an appendix to this chapter. It should be noted that in considering the net disposable incomes of working families, we are not starting from a level playin ${ }^{\mathrm{g}}$ field. because average gross male earnings differ between countries. Earnings in Greece and Portugal were between a third and half of earnings in the USA and Canada -- after taking account of differences in purchasing power. Earnin ${ }^{\mathrm{g}_{\mathrm{S}}}$ in Spain were also lower than in the other countries. Among the remaining countries, earnings were remarkably similar, with three exceptions -- Finland. Sweden and France - which had average earnings of about 1500 (USS795) per month lower than Canada. in purchasing power parity terms. That these three countries had earnings levels so much lower than the rest calls for some explanation. It is no doubt partly a function of purchasing power parities, but we believe that it is mainly related to the level of the 'social wage' in those countries. Thus in France, employers' social security contributions represented 38 per cent of average earnings. Similarly, in Sweden they represented 35 per cent of average earnings, while in Finland the combination of employers' social security and compulsory superannuation contributions brought the total to more than 22 per cent of average wages. It is likely that what is happening in these countries is that workers are effectively foregoing higher earnings for the benefits - often in the future - of a generous social wage. These high social security contributions can thus be seen as a form of deferred wa ${ }^{\mathrm{g}} \mathrm{e}$. By contrast, earnings are higher in Canada and the USA, for example, partly because employers are not required to contribute so much to a social wage. If this is the explanation for these differences. then as Whiteford (1995) has argued, when comparing the earnings levels of workers between countries it might be more appropriate to include employers' social security contributions as part of earnings. This, however. has not been done in the present analysis.

The calculation of cash benefits received and tax and social security contributions payable were relatively straightforward, given the model families' income and household circumstances. However, the calculation of other elements of the package called for the establishment of a common context and framework for the analysis. One of the most problematic areas is that of housing costs.

\section{I-Iousing costs}

Housing costs are especially difficult to take into account in comparative research. Costs vary within countries and between countries according to tenure and the size, age and location of the dwellings. In some countries rents may be controlled for those persons occupying dwellings before a certain date. For owner-occupiers, loan structures and interest rates vary between countries, often according to the stage in the economic cycle. while the level of mortgage interest is also affected by the stage of a purchaser's life cycle. There are also significant differences between countries in tenure distribution at different income levels. Nevertheless, housing costs cannot be ignored. In many countries, help with housing costs is a critical element in the benefit package, and even where such support does not exist. variations in housing costs mean that real income levels differ substantially before and after taking account of housing. For this exercise. the families were assumed to be living in rented dwellings rented from a public authority, housing co-operative or housing association, if they were common forms of tenure in the country, or from a private landlord if that was the most common tenure pattern. In those countries with high levels of owner-occupation, this assumption is less representative. However, leaving aside the difficulties of making assumptions about owner-occupiers' costs, families receiving social assistance are more likely than others in most countries to be living in rented dwellings. 
National informants were asked to fix typical or representative rent levels for such dwellings in a given town in their country. There is an argument for using national average rents rather than local estimates, but previous experience has suggested that up-to-date information on average rents is often not available. Locating the families in a given commune, town or city, helps to structure the comparisons where benefits vary locally, but it can be difficult in some countries to nominate a typical or 'average' location. The size of the dwellings was specified and varied with the model families, so that single people were assumed to be living in one-bedroom dwellings, couples without children and lone parents and couples with one child in two-bedroom dwellings, and lone parents and couples with two children in threebedroom dwellings. Again, this is an artificial assumption. as families on constrained incomes will in practice make different choices in response to local housing markets. The national informants were left to determine whether the dwelling was a house or a flat/apartment on the basis of what was the most likely accommodation type in their country.

Informants were also asked to provide the gross rent. One defect of this method is that it does not take account of the value of any bricks-and-mortar subsidy on the dwelling - the difference between the market rent and the gross rent. If certain families are benefiting more than other households from living in houses with bricks-and-mortar subsidy, and therefore have lower rents for the same dwelling, the support package for such families will be under-estimated. It is also anomalous that the rents assumed in some countries are those subject to rent control. In these cases the rent is being subsidised by the landlord.

Table 6.1. shows that the designated rents varied substantially between the nominated locations, even for the same size dwelling: for a two-bedroom dwelling they ranged, in purchasing power parities, from a controlled rent of $£ 55$ (S87) per month in Barcelona, to $£ 386$ 6614) in Sydney. The ratio of rents for dwellings of different sizes also varied between countries. Thus, for example, in Austria, Greece and Portugal. the rents for three-bedroom dwellings were about twice that of a one-bedroom dwelling, but in France a three-bedroom dwelling cost only one-third more than a one-bedroom dwelling. In Barcelona, the controlled rents meant that costs did not vary according to the size of the dwelling. These variations, along with the assumptions inevitably underlying the nomination of the rent figures. illustrate the very considerable problems involved in taking account of housing costs in this kind of analysis. 
(able 6.1: Gross rents nominated by the national $\mathrm{f}$ on ants in purchasing power pa $\mathrm{Y}$. sterling and USS, per month.. 1992

\begin{tabular}{|c|c|c|c|c|c|c|}
\hline & \multicolumn{2}{|c|}{$\begin{array}{l}\text { One bedroom } \\
\text { dwelling }\end{array}$} & \multicolumn{2}{|c|}{$\begin{array}{l}\text { Two bedroom } \\
\text { dwelling }\end{array}$} & \multicolumn{2}{|c|}{$\begin{array}{l}\text { 'three bedroom } \\
\text { dwelling }\end{array}$} \\
\hline & $\mathfrak{f}$ & S & $£$ & $\mathrm{~s}$ & $£$ & S \\
\hline $\begin{array}{l}\text { Australia } \\
\text { Parramatta, Sydney }\end{array}$ & 285 & 453 & 386 & 614 & 499 & 793 \\
\hline $\begin{array}{l}\text { Parramatta, Sydney } \\
\text { Austria } \\
\text { Salzburg }\end{array}$ & 242 & 385 & $? 5^{?}$ & 560 & 484 & 769 \\
\hline $\begin{array}{l}\text { Belgium } \\
\text { Antwern }\end{array}$ & 131 & 208 & 163 & 259 & 183 & 291 \\
\hline $\begin{array}{l}\text { Canada } \\
\text { Toronto, Ontario }\end{array}$ & 305 & 485 & 376 & 598 & 452 & 719 \\
\hline $\begin{array}{l}\text { Denmark } \\
\text { Copenhagen }\end{array}$ & 201 & 320 & 244 & 388 & 316 & 502 \\
\hline $\begin{array}{l}\text { Finland } \\
\text { Helsinki }\end{array}$ & 198 & 315 & 246 & 391 & 272 & 432 \\
\hline France & 62 & 98 & 79 & 125 & 90 & 143 \\
\hline $\begin{array}{l}\text { Bar-le-d tuc. Meuse } \\
\text { Germany } \\
\text { Bremen }\end{array}$ & 194 & 122 & 239 & 380 & 299 & 475 \\
\hline $\begin{array}{l}\text { Greece } \\
\quad \text { Peristeri. Athens }\end{array}$ & 108 & 171 & 163 & 259 & 217 & 345 \\
\hline $\begin{array}{l}\text { Iceland } \\
\text { Reykjavik }\end{array}$ & 220 & 350 & 256 & 407 & 294 & 467 \\
\hline $\begin{array}{l}\text { Ireland } \\
\text { Dublin }\end{array}$ & 146 & 232 & 214 & 340 & 243 & 386 \\
\hline $\begin{array}{l}\text { Italy } \\
\text { Turin }\end{array}$ & 87 & 138 & 111 & 176 & 127 & 201 \\
\hline Japan & 205 & 326 & 275 & 437 & 384 & 610 \\
\hline $\begin{array}{l}\text { Osaka } \\
\text { Luxembourg } \\
\text { Luxembourg City }\end{array}$ & 107 & 171 & 153 & 243 & 183 & 290 \\
\hline $\begin{array}{l}\text { Netherlands } \\
\mathrm{N} \mathrm{j} \text { imegeri }\end{array}$ & 101 & 160 & 115 & 182 & 145 & 230 \\
\hline $\begin{array}{r}\text { New Zealand } \\
\text { Wellington }\end{array}$ & 185 & 294 & 235 & 374 & 258 & 410 \\
\hline $\begin{array}{l}\text { Norway } \\
\text { Oslo }\end{array}$ & 239 & 380 & 286 & 455 & 375 & 596 \\
\hline $\begin{array}{l}\text { Portugal } \\
\text { Lisbon }\end{array}$ & 80 & 127 & 134 & 213 & 161 & 256 \\
\hline $\begin{array}{l}\text { Spain } \\
\text { Barcelona }\end{array}$ & 55 & 87 & 55 & 87 & 55 & 87 \\
\hline $\begin{array}{l}\text { Sweden } \\
\text { Stockholm }\end{array}$ & 199 & 316 & 253 & 402 & 310 & 493 \\
\hline $\begin{array}{l}\text { Switzerland } \\
\text { Fribour }^{\mathrm{g}} \text {, Canton de } \\
\text { Fribour }^{\mathrm{g}}\end{array}$ & 299 & 475 & 385 & 612 & 470 & 747 \\
\hline $\begin{array}{l}\text { United Kingdom } \\
\text { York }\end{array}$ & 95 & 151 & 117 & 186 & 131 & 208 \\
\hline USA New York & 290 & 732 & 352 & 559 & 414 & 658 \\
\hline USA Pennsylvania & 234 & 372 & 327 & 520 & 425 & 675 \\
\hline USA Texas & 205 & 326 & 270 & 429 & 371 & 590 \\
\hline USA Florida & 246 & 391 & 253 & 402 & 340 & 540 \\
\hline
\end{tabular}

SIUS $=£ 0.629$ PPP in 1992

National informants were then asked to give the net rent - that is the rent actually payable by a family of the specified type and earnings level. The difference between the gross rent and the net rent was then treated as part of the package of support. There is no denying that these assumptions are both arbitrary and unsatisfactory in many respects. However to have ignored altogether the impact of housing costs and housing subsidies would have been misleading.

Housing costs are not only a problem at the design stage of comparative projects, they are also difficult to handle at the analysis stage - particularly in a study comparing the level of social assistance payments. The problem arises because, in some countries, housing costs. or a proportion of them, are paid together with social assistance. Thus the basic benefit takes account of some or all housing costs. 
In other countries, housing costs are subsidised either by a reduction in rent payable, or by a housing benefit or allowance scheme which is administered separately from social assistance. If comparisons are made of the level of social assistance before housing costs_ then the first group of countries - those that pay the housing subsidy in with social assistance -- will appear to have higher levels than the others. The answer to this is to avoid making comparisons of social assistance before housing costs and to concentrate on comparisons after housing costs, when income net of housing represents the income people have left to spend on living costs other than their housing. However_there are three objections to this approach:

- Housing is a consumer good, of which people are more or less free to make choices about the quality and quantity they consume. It is not in the same category as income tax or social security deductions. People in countries where standard housing allowances are paid in with social assistance could choose to consume less housing and use the element of their benefit provided for housing for general consumption. A possible solution would be to identify the element in social assistance that represents housing costs and deduct it from benefits. But to do that would be to misrepresent the actual resources that the family has command over, and for some countries it is not possible to identify the housing element separately.

- Similarly, families in those countries with housing benefit schemes could theoretically move to more expensive housing and pay higher rent, without it affecting their net disposable resources (except if the rent is considered unreasonable in the housing benefit scheme).

(B) As we have seen, the rents of the dwellings in each country vary considerably. The quality of the housing will also vary, though not necessarily with the level of the rent. Therefore, if social assistance is compared only after housing costs. the families would not necessarily be starting from the same standard of living.

There is no simple solution to these problems. It would be wrong to compare social assistance only before housing. yet it would also be misleadin ${ }^{g}$ in certain circumstances to compare social assistance incomes only after housing. The answer we believe is to present the results in most circumstances both before and after housing costs, but also to bear in mind that results after housing costs are strongly affected by the assumptions made.

\section{Local taxes}

National informants were also asked to take account of any local taxes payable in a given location and the impact of any subsidies. If the tax was a local income tax, contributin $^{\mathrm{g}}$ to national revenues. it was included with income tax.

\section{Health costs}

In order to take account of the value of health care in the countries, it was again necessary to establish a standard package. The base line assumptions were that health care at the point of demand was free of charge, available to all regardless of means and of similar quality in every country. Account was then taken of any variations from these assumptions. In taking account of variations, a standard package of health was costed in each country. This included any charges for three prescriptions per person per year for a standard antibiotic; one week in hospital per person per year (this is an unlikely assumption, but in practice in no country did it actually make a difference. because where there were in-patient charges it was assumed that insurance premiums covered the whole family); three visits to a general practitioner per person per year: and one visit to a dentist for a check-up and filling per person per year. The costs were estimated for both adults and children, where they existed, then annualised and turned into a monthly charge. The major problem with these assumptions is that for those countries - including 
Greece. Portugal, Spain and to some extent Italy . where in theory there is access to public health services but in practice the quality may be poor or the waiting lists long, families often tend to use private treatment.

\section{School and child-care costs}

In order to take account of the costs or value of free or subsidised pre-school provision, a standard package was again established for each country. National informants were asked to follow the most prevalent pattern of formal, full-time, pre-school provision in their country and to take account of the costs of this provision. This resulted in different types of care being costed in each country, and no account was taken of any variations in the quality of that care. In this study. pre-school costs were only taken into account in the case of the working lone parent with a pre-school a ${ }^{\mathrm{g}} \mathrm{e}$ child.

It was assumed as a base line that school education of an equivalent standard. including basic books, was available free of charge to all children of school age. It was assumed that parents would have to pay for a midday meal, and that children lived near enough their school not to require school transport. Account was then taken of any charges that parents were expected to pay for education and any benefits (including the value of free or subsidised school meals) that they might receive.

\subsection{Limitations of the model family approach}

The assumptions described above are essential to the task of simulating policy by obtaining comparable information on an up-to-date basis. However, there are several disadvantages, in addition to the problems discussed earlier. First, this method inevitably produces a description of the way the system should work rather than how it necessarily does. For example, the study implicitly assumes that all those eligible for means-tested benefits are claiming them, despite the fact that take-up of these benefits is known to be far from complete in some countries. It is possible to address this difficulty at the analysis stage by excluding such benefits, or even by building in some assumptions on take-up, but because of the complexity of the interactions within the different systems this is not always a safe or easy solution. The data on which to ground these assumptions are also often missing. Other behavioural effects of policy are also inevitable missing from the analysis. For example, the high cost of formal child care in some countries means that in practice many working lone parents find other informal solutions. In modelling their net incomes, it may, therefore, be unrealistic to take child-care costs into account. These are limitations which make it necessary always to emphasise that it is the structural features of tax/benefit systems which are being compared. not the outcomes for actual families. Concentrating on the formal arrangements and the intended impact of the policies one is seeking to evaluate can, however, be as valid as looking at the actual impact.

Secondly. looking at families at one point in time obscures the more complex lifecycle effects of taxlbenefit systems. In particular, while employees' social security contributions are taken into account as reducing disposable income, there is no way of modelling the future benefits which accrue from them. In so far as higher contributions may bring better benefits (which is not always the case). this may distort the picture for some countries from a longer-term perspective, especially in relation to retirement pensions. However, by counting benefits received at the time, some account is taken of the distributive effect of contributions previously paid by the family in question and by other contributors.

Thirdly, the more assumptions that are made about the circumstances of the model families, the less representative those families are of actual populations. This problem is the inevitable cost of achieving comparability. It has to be accepted that the model families in the study are most unlikely to exist in all their characteristics in any country. They are not representative but illustrative. They illustrate a range of experience, and being comparable they enable us to demonstrate and compare 
the tax/benefit 'environment' implicitly created for families in a variety of circumstances in a number of countries. Ideally other families and other aspects of the benefit systems would have been included. However. with three categories of benefit. nine family types, two adult ages, three children's ages and a variety of different benefit systems in each country, the matrix was al 'eady large and complex.

Finally, it needs to be emphasised that the matrix figures for countries with local assistance schemes often have to be viewed differently from those where there are national scale rates, such as Australia and the UK. or where regional variations are slight, such as Germany. In countries like Switzerland, Norway and Italy. in particular, but others too. the amount of benefit paid to particular families depends not only on their individual circumstances, but also on the discretion of local social workers operating within local guidelines. For these countries, the figures given are the best estimates of the national experts, but they apply only to the specified municipality and cannot necessarily he seen as representative of the country as a whole. The tables need to be read, therefore, not only with any relevant footnotes. but also alongside the descriptive material in earlier chapters and in Volume Two. The first set of tables specifies the location along with the country. From then on. for ease of presentation, only the countries are given, but the locations should always he borne in mind when looking at the data from countries without national systems.

\section{Purchasing power parities}

Comparisons of the levels on benefits payable in this study use purchasing power parities (PPPs). As was explained in Chapter One, PPPs are a method of comparing the actual value of a currency in terms of purchasing power. They have their limitations, but it can be argued that they are the best available way of comparing the value of benefit packages across countries. Table A6.2 at the end of this chapter compares PPPs with exchange rates for May 1992.

\subsection{The results of the income matrix analysis}

\section{The structure of , social assistance}

The assumptions outlined above indicate that the social assistance package is made up of a variety of elements a combination of benefits and costs. This can be illustrated by examining the structure of the social assistance package for three different family types - a childless couple, a pensioner couple and a couple with two school age children.

Tables 6.2a and 6.2b show the structure of social assistance for a childless couple. Before housing costs. the social assistance package in seven countries. including the UK, was entirely made up of the cash benefit itself: in these countries the:re were no deductions of tax or social security, or expenses for health or education. to be paid out of the benefit. and no other sources of income. Only New Zealand charged income tax on social assistance and only Luxembourg required recipients of social assistance to make a social security contribution. About half the countries had some health charges which had to be paid out of social assistance benefits. These were for most countries small amounts, but in France and Switzerland they consumed over ten per cent of the social assistance paid. Four countries had other types of payment in addition to the social assistance scales. In the case of Canada this was a refundable tax credit. in the USA it was Food Stamps, in Italy it was the Household Allowance, and in Ireland it was the Electricity Supplement. Of these. Food Stamps were by far the most valuable, accounting for over a quarter of the total social assistance package in the USA. Table 6.2b shows the (substantial) impact of the nominated housing costs. In Austria. Finland and Germany, there were no housing costs for couples receiving social assistance and in the UK they were relatively small - 20 per cent of the Community Charge (poll tax) in 1992 (the requirement to make this payment while on Income Support has since been abolished for the current form of local taxation). In the other countries, housing 
costs were very important thus in Greece they cancelled out the value of the limited social assistance available. In New York (USA) they consumed most of social assistance. while in Florida they resulted in a notional negative figure. In Switzerland (Fribourg). they took up nearly half of the cash payment. The Nordic countries, apart from Finland. also had housing costs which consumed over a quarter of social assistance paid.

Table 6.2a: Structure of the social assistance package. Couple aged 35. Amounts per month in E. and \$ PPPs (before housing costs), 1992

\begin{tabular}{|c|c|c|c|c|c|c|c|c|c|c|c|c|}
\hline & \multicolumn{2}{|c|}{$\begin{array}{c}\text { Social } \\
\text { assistance }\end{array}$} & \multicolumn{2}{|c|}{$\begin{array}{l}\text { Income } \\
\operatorname{tax}\end{array}$} & \multicolumn{2}{|c|}{$\begin{array}{c}\text { Employee } \\
\text { contribution }\end{array}$} & \multicolumn{2}{|c|}{$\begin{array}{c}\text { Health } \\
\text { costs }\end{array}$} & \multicolumn{2}{|c|}{ Other } & \multicolumn{2}{|c|}{ Total } \\
\hline & & $\mathbf{S}$ & $£$ & S & $£$ & $\$$ & $£$ & $S$ & $£$ & S & $£$ & $S$ \\
\hline $\begin{array}{l}\text { Australia } \\
\text { Parramatta. } \\
\text { Sydney }\end{array}$ & 519 & 825 & 0 & & 0 & & & & 0 & & 515 & 818 \\
\hline $\begin{array}{l}\text { Austria } \\
\text { Salzburg }\end{array}$ & 247 & 393 & 0 & & 0 & & 0 & & 0 & & 247 & 393 \\
\hline $\begin{array}{l}\text { Bel }{ }^{g} \text { ium } \\
\text { Antwerp }\end{array}$ & 407 & 647 & 0 & & 0 & & 7 & -11 & 0 & & 400 & 636 \\
\hline $\begin{array}{l}\text { Canada } \\
\text { Toronto, Ontario }\end{array}$ & 432 & 687 & 0 & & 0 & & -3 & 4 & 36 & & 465 & 740 \\
\hline $\begin{array}{l}\text { Denmark } \\
\text { Copenhagen }\end{array}$ & 559 & 889 & 0 & & 0 & & & & 0 & & 557 & 885 \\
\hline $\begin{array}{l}\text { Finland } \\
\text { Helsinki }\end{array}$ & 338 & 537 & 0 & & 0 & & -20 & $-3 ?$ & 0 & & 318 & 505 \\
\hline $\begin{array}{l}\text { hrance } \\
\text { Bar-le-due, Meuse }\end{array}$ & 264 & 420 & 0 & & 0 & & -30 & -48 & 4 & & 235 & 372 \\
\hline (3erfmany & 258 & 410 & 0 & & 0 & & 0 & & 0 & & 258 & 410 \\
\hline $\begin{array}{l}\text { Bremen } \\
\text { Greece' } \\
\text { Peristeri, Athens }\end{array}$ & 30 & 48 & 0 & & 0 & & 0 & & 0 & & 30 & 48 \\
\hline $\begin{array}{l}\text { Iceland } \\
\text { Reykjavik }\end{array}$ & 632 & 1.005 & 0 & & 0 & & --12 & -19 & 0 & & 620 & 986 \\
\hline $\begin{array}{l}\text { Ireland } \\
\text { Dublin }\end{array}$ & 349 & 555 & 0 & & 0 & & 0 & & 10 & 16 & 360 & 571 \\
\hline $\begin{array}{l}\text { Italy }= \\
\text { Turin }\end{array}$ & 415 & 660 & 0 & & 0 & & 0 & & 30 & & 444 & 706 \\
\hline $\begin{array}{l}\text { Japan } \\
\text { Osaka }\end{array}$ & 397 & 631 & 0 & & 0 & & 0 & & 0 & & 397 & 631 \\
\hline $\begin{array}{l}\text { Luxembourg } \\
\text { Luxembourg City }\end{array}$ & 560 & 890 & 0 & & -13 & $\cdots 21$ & -5 & & 0 & & 542 & 862 \\
\hline $\begin{array}{l}\text { Netherlands } \\
\text { Njimegen }\end{array}$ & 523 & 831 & 0 & & 0 & & -16 & 25 & 0 & & 507 & 806 \\
\hline $\begin{array}{l}\text { New Zealand } \\
\text { Wellington }\end{array}$ & 449 & 714 & -67 & 107 & 0 & & --11 & -17 & 0 & & 371 & 591 \\
\hline $\begin{array}{l}\text { Norway } \\
\text { Oslo }\end{array}$ & 626 & 995 & 0 & & 0 & & & $\therefore 11$ & 0 & & 619 & 984 \\
\hline $\begin{array}{l}\text { Portugal } \\
\text { Lisbon }\end{array}$ & 158 & 251 & 0 & & 0 & & 0 & & 0 & & 158 & 251 \\
\hline $\begin{array}{l}\text { Spain } \\
\text { Barcelona }\end{array}$ & 231 & 367 & 0 & & 0 & & -5 & -9 & 0 & & 225 & 358 \\
\hline $\begin{array}{l}\text { Sweden } \\
\text { Stockholm }\end{array}$ & 577 & 917 & 0 & & 0 & & -12 & $\therefore 19$ & 0 & & 565 & 898 \\
\hline $\begin{array}{l}\text { Switzerland } \\
\text { Fribour }^{\mathrm{g}} \text {, Canton } \\
\text { de Fribourg }\end{array}$ & 906 & 1,440 & 0 & & 0 & & -105 & -167 & 0 & & 801 & 1.273 \\
\hline $\begin{array}{l}\text { UK } \\
\text { York }\end{array}$ & 289 & 460 & 0 & & 0 & & 0 & & 0 & & 289 & 460 \\
\hline USA Nev York & 296 & 471 & 0 & & 0 & & 0 & & 0 & & 403 & 641 \\
\hline USA Pennsylvania & 199 & 316 & 0 & & 0 & & 10 & -16 & 52 & 83 & 241 & 383 \\
\hline USA Texas & 0 & & 0 & & 0 & & 6 & -10 & 128 & 203 & 122 & 193 \\
\hline USA Florida & 0 & & 0 & & 0 & & 0 & & 128 & 203 & 128 & 203 \\
\hline
\end{tabular}

1992 USS 63 pence PPP rate

Since Greece has no general social assistance this figure and those in other tables are based on an assumption that people receive the full yearly amount of lump sum Special Assistance available

For non-pensioner households, the Italian figures should be regarded with particular caution. They represent optimistic assumptions about the likelihood and the level of awards to these households 
Table 6.26: Structure of the social assistance package. Couple 35. Amounts per month in $\mathrm{r}$ and S PPPs (after housing costs), 1992

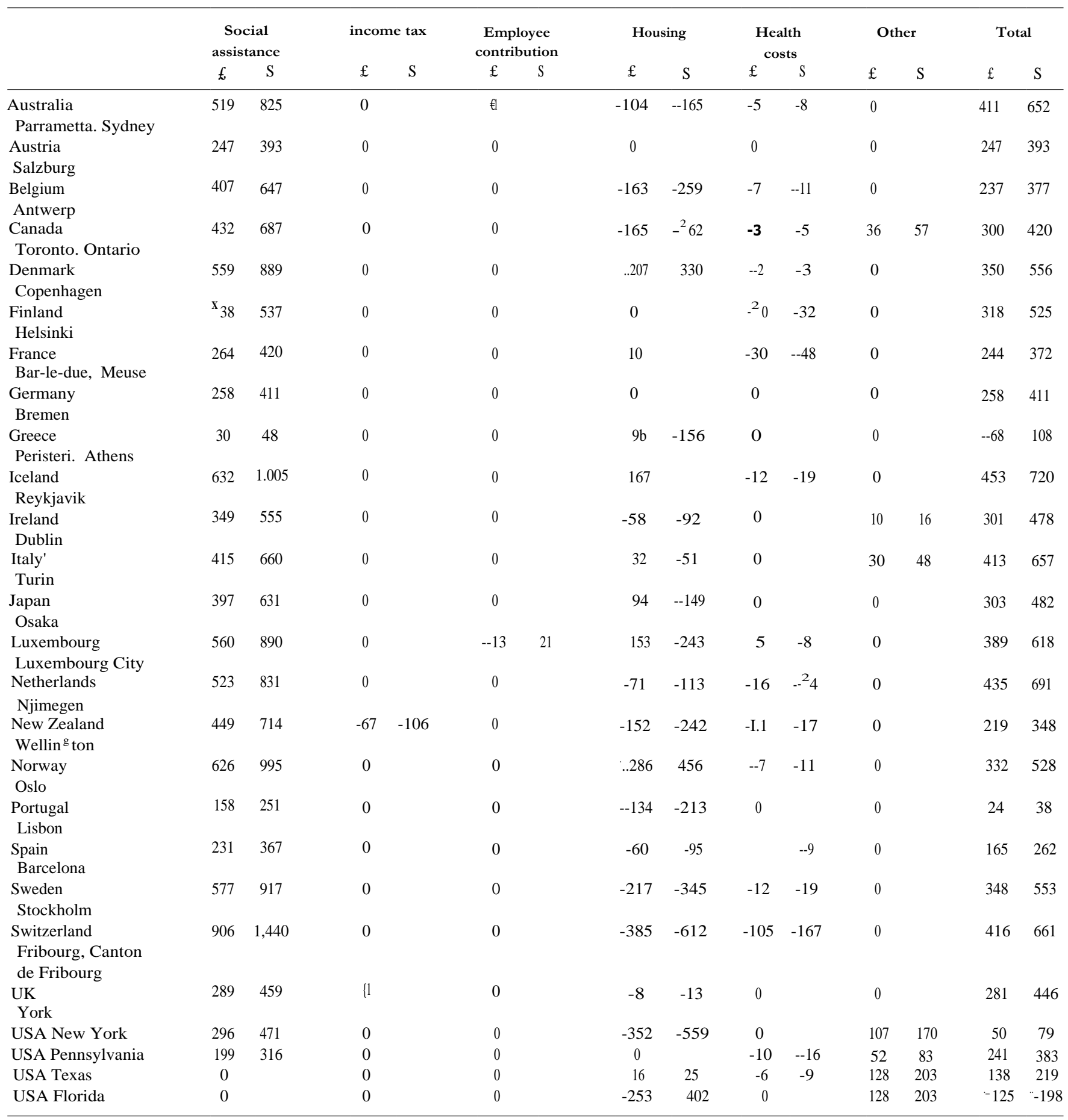

1992 USSI $=63$ pence

For non-pensioner households, the Italian figures should be regarded with particular caution. They represent optimistic assumptions about the likelihood and the level of awards to these households 
Table 6. 3 provides the results for a pensioner couple - this time only after housing costs. Income tax was payable in Denmark and New Zealand (this is not. in fact. social assistance in Denmark but, as with Finland,the minimum non-contributory retirement pension). Social security contributions were again payable in Luxembourg. Fewer countries had health costs for pensioners on social assistance and where they did, they were fairly small, with the exception of Switzerland. Canada had a refundable tax credit. Finland the minimum pension. Ireland the electricity allowance and the USA Food Stamps. In most countries, pensioners' housing costs were identical to those of the childless couple, but in Canada, Greece and the Netherlands. pensioners paid more than childless couples, while in Denmark and New Zealand they paid less, In most cases these differences were offset by adjustments to the social assistance payable. 
7 blc 6.3: Structure of social assistance package. Couple aged 68. Amounts per month in C and \$ PPPs tarter housing costs), 1992

\begin{tabular}{|c|c|c|c|c|c|c|c|c|c|c|c|c|c|c|}
\hline & \multicolumn{2}{|c|}{ Social assistance } & \multicolumn{2}{|c|}{ income tax } & \multicolumn{2}{|c|}{ Employee contribution } & \multicolumn{2}{|c|}{ Housing } & \multicolumn{2}{|c|}{ Health costs } & \multicolumn{2}{|c|}{ Other } & \multicolumn{2}{|c|}{ Total } \\
\hline & $£$ & S & $£$ & $\$$ & $£$ & $: 6$ & $£$ & $S$ & $£$ & $\$$ & $£$ & $\mathrm{~S}$ & $£$ & $\mathbf{S}$ \\
\hline Australia & 519 & 825 & 0 & & 0 & & 04 & 165 & -5 & 8 & o & & 411 & 653 \\
\hline Austria & 288 & 458 & 0 & & 0 & & 0 & & 0 & & 0 & & 288 & 457 \\
\hline Belgium & 407 & 647 & 0 & & 0 & & $\therefore 163$ & 259 & -3 & -5 & 0 & & 241 & 383 \\
\hline Canada & 748 & 1,188 & 0 & & 0 & & -305 & 485 & -3 & -5 & 46 & 73 & 486 & 773 \\
\hline Denmark & 653 & 1.038 & -13 & -21 & 0 & & -92 & -146 & --2 & 3 & 0 & & 546 & 868 \\
\hline Finland & 49 & 124 & 0 & & 0 & & 0 & & .20 & -32 & 397 & 631 & 426 & 677 \\
\hline France & 523 & 831 & 0 & & 0 & & 10 & 16 & $-3 \notin 1$ & -47 & 0 & & 503 & 800 \\
\hline Germany & 309 & 491 & 0 & & 0 & & 0 & & 0 & & 0 & & 309 & 491 \\
\hline Greece & 76 & 121 & 0 & & 0 & & --ILO & -175 & 0 & & 0 & & -34 & 54 \\
\hline Iceland & 632 & '1,005 & 0 & & 0 & & 167 & -266 & -12 & 19 & 0 & & 453 & 720 \\
\hline Ireland & 370 & 588 & 0 & & 0 & & 58 & -92 & 0 & & 33 & 52 & 345 & 548 \\
\hline Italy' & 415 & 660 & 0 & & 0 & & -32 & -51 & 0 & & 0 & & 383 & 609 \\
\hline japan & 373 & 593 & 0 & & 0 & & --94 & 149 & 0 & & 0 & & 279 & 443 \\
\hline Luxembourg & 560 & 890 & 0 & & -10 & 16 & 153 & 243 & -5 & -8 & 0 & & 392 & 623 \\
\hline Netherlands & 523 & 831 & 0 & & 0 & & -92 & 146 & -16 & -25 & 0 & & 415 & 660 \\
\hline New Zealand & 592 & 941 & -89 & _141 & 0 & & 72 & 273 & -11 & 47 & 0 & & 321 & 510 \\
\hline Norway & 544 & 865 & 0 & & 0 & & .205 & 326 & -7 & -11 & t.) & & 332 & 528 \\
\hline Portugal & 156 & 248 & 0 & & 0 & & 34 & -213 & 0 & & 0 & & 23 & 36 \\
\hline Spain & 228 & $36^{2}$ & 0 & & 0 & & -60 & -95 & -5 & --8 & 0 & & 163 & 259 \\
\hline Sweden & 465 & 739 & 0 & & 0 & & -25 & -40 & $1^{2}$ & 19 & 0 & & 427 & 679 \\
\hline Switzerland & 906 & 1,440 & 0 & & 0 & & .385 & 612 & 105 & -167 & 0 & & 416 & 661 \\
\hline UK. & 385 & 612 & 0 & & 0 & & -4 & 12 & 0 & & 0 & & 377 & 593 \\
\hline USA NY & 463 & 736 & 0 & & 0 & & -352 & -560 & 0 & & 50 & 79 & 161 & 260 \\
\hline USA Pen & 429 & 682 & 0 & & 0 & & 0 & & 10 & 16 & 61 & 97 & 480 & 763 \\
\hline USA. Texas & 398 & 633 & 0 & & 0 & & 07 & -170 & -1 & -15 & 70 & 111 & 360 & 572 \\
\hline USA Florida & 398 & 633 & 0 & & 0 & & -253 & 402 & 0 & & 70 & 111 & 215 & 342 \\
\hline
\end{tabular}

'For non-pensioner households, the Italian figures should be regarded with particular caution. They represent optimistic assumptions about the likelihood and the level of awards to these households 
Table 6.4 presents the results for a couple with two school-aged children, after housing costs. For people with children, the social assistance package is more complex than for those without children. With the exception of Switzerland (remembering that this applies specifically to Fribourg), all countries paid either an income-related or non-income-related cash payment in respect of children, in addition to the social assistance figure in the first column. In Australia, Austria and Belgium this represented over a quarter of the total package. Only in New Zealand did families on social assistance pay income tax and in Luxembourg social security contributions. There were health charges to be paid in about half of the countries, though they only exceeded ten per cent of the social assistance payments in France and Switzerland. There were costs associated with education in six countries and school meals subsidies in four countries. including the UK. In five countries there were other types of additional payments -- in Canada the tax credit. in Germany a child tax credit, in Ireland the electricity allowance, in Italy the household allowance and in the USA the Supplementary Food Programme for Women, Infants and Children (WIC) and Food Stamps.

In all but three countries (Austria, Germany and Finland). people had to pay housing costs out of their social assistance. though the amounts varied from $£ 8$ (\$13) per month in the UK (for the Community Charge which has since been abolished') to $£ 470$ (\$747) per month in Switzerland. In Belgium, Luxembourg, Spain, Portugal, Switzerland and two of the four US States, recipients of social assistance paid the full gross rent. The value of the rent subsidy in the other countries depended to some extent on the level of the gross rent, but it was worth over $£ 200$ (\$318) per month in Austria, Finland, Germany. Australia, Japan, Canada and Ireland and over $£ 100$ (\$160) a month in the UK, Sweden. Iceland and Denmark.

In the UK, Income Support rates were increased at the time of the introduction of the Community Charge to provide some compensation. but this increase was not clawed back when the tax was abolished. 


\begin{tabular}{|c|c|c|c|c|c|c|c|c|c|c|c|c|c|c|c|c|c|c|c|c|}
\hline & \multicolumn{2}{|c|}{$\begin{array}{c}\text { Social } \\
\text { assistance }\end{array}$} & \multicolumn{2}{|c|}{$\begin{array}{c}\text { Child } \\
\text { benefit }\end{array}$} & \multicolumn{2}{|c|}{$\begin{array}{l}\text { Means } \\
\text { tested child } \\
\text { benefit }\end{array}$} & \multicolumn{2}{|c|}{ Income tax } & \multicolumn{2}{|c|}{$\begin{array}{l}\text { Employee } \\
\text { contribution }\end{array}$} & \multicolumn{2}{|c|}{ Housing } & \multicolumn{2}{|c|}{ Health costs } & \multicolumn{2}{|c|}{ Education } & \multicolumn{2}{|c|}{ Other } & \multicolumn{2}{|c|}{ Total } \\
\hline & $\mathfrak{£}$ & $\$$ & $\mathfrak{£}$ & $\$$ & $£$ & $\$$ & $£$ & $\$$ & $£$ & $\$$ & $£$ & $\$$ & $£$ & $\$$ & $£$ & $\$$ & $\mathfrak{£}$ & S & $£$ & s \\
\hline Australia & 519 & 825 & & 67 & 123 & 196 & 0 & 0 & 0 & 0 & -137 & -218 & -5 & --8 & 0 & 0 & 0 & 0 & 543 & 863 \\
\hline Austria & 333 & 529 & 143 & 227 & 18 & 29 & 0 & 0 & 0 & 0 & 0 & 0 & 0 & 0 & 0 & 0 & 0 & 0 & 494 & 785 \\
\hline Belgium & 407 & 647 & 0 & 0 & 182 & 289 & 0 & 0 & 0 & 0 & -183 & 291 & --11 & -17 & -23 & -37 & 0 & 0 & 372 & 591 \\
\hline Canada & 539 & 857 & 35 & 55 & 50 & 79 & 0 & Cl & 0 & 0 & -245 & 390 & --3 & -5 & 8 & 13 & 47 & 75 & 432 & 687 \\
\hline Denmark & 602 & 957 & 65 & 103 & 0 & 0 & 0 & 0 & 0 & 0 & 177 & 281 & --2 & 3 & 0 & 0 & 0 & 0 & 488 & 775 \\
\hline Finland & 542 & 861 & 75 & 119 & 0 & 0 & 0 & 0 & 0 & 0 & 0 & 0 & 37 & -59 & 0 & 0 & 0 & 0 & 580 & 922 \\
\hline France & 319 & 507 & 60 & 95 & 6 & 10 & 0 & 0 & 0 & 0 & 21 & 33 & 59 & --94 & 52 & 83 & 0 & 0 & 398 & 633 \\
\hline Germany & 379 & 602 & 42 & 67 & 18 & 29 & 0 & 0 & 0 & 0 & 0 & 0 & 0 & 0 & 0 & 0 & 39 & 42 & 477 & 758 \\
\hline Greece & 30 & 48 & 0 & 0 & 11 & 17 & $(1$ & 0 & 0 & 0 & 145 & --231 & 0 & 0 & 0 & 0 & 0 & 0 & $1(13$ & 164 \\
\hline Iceland & 717 & 1,140 & 22 & 35 & 104 & 165 & 0 & 0 & 0 & 0 & $\cdot 179$ & -285 & -21 & --33 & 0 & 0 & 0 & 0 & 644 & 1,024 \\
\hline Ireland & 450 & 715 & 31 & 49 & 0 & $(1$ & 0 & 0 & 0 & 0 & -49 & -78 & 0 & 0 & -10 & -16 & 10 & 16 & 433 & 688 \\
\hline Italy' & 476 & 757 & 0 & 0 & 0 & 0 & 0 & 0 & 0 & 0 & --32 & $\ldots 51$ & 0 & 0 & (1 & 0 & 59 & 94 & 503 & 800 \\
\hline Japan & 663 & 1,054 & 0 & 0 & 0 & 0 & 0 & 0 & 0 & 0 & -203 & 323 & 0 & 0 & 0 & 0 & 0 & 0 & 460 & 731 \\
\hline Luxembourg & 637 & 1,013 & 162 & 257 & 0 & 0 & 0 & 0 & --17 & -27 & 183 & 291 & --11 & -17 & -12 & --19 & 0 & 0 & 577 & 917 \\
\hline Netherlands & 523 & 831 & 106 & 168 & 0 & 0 & 0 & 0 & 0 & 0 & ---98 & 156 & -23 & -37 & 12 & $" 19$ & 0 & 0 & 496 & 789 \\
\hline New Zealand & 477 & 758 & 0 & 0 & 112 & 178 & ---72 & 114 & 0 & 0 & 183 & 291 & --14 & --22 & --7 & $\therefore 11$ & 0 & 0 & 313 & 498 \\
\hline Norway & 735 & 1,169 & 119 & 189 & 0 & 0 & 0 & 0 & 0 & 0 & 299 & 475 & 9 & 44 & 0 & 0 & 0 & 0 & 546 & 868 \\
\hline Portugal & 158 & 251 & 0 & 0 & 24 & 38 & 0 & 0 & 0 & 0 & -161 & -256 & 0 & 0 & 0 & 0 & 0 & 0 & 21 & 33 \\
\hline Spain & 280 & 445 & 0 & 0 & 32 & 51 & 0 & 0 & 0 & 0 & -60 & ---95 & --11 & -17 & -8 & --13 & 0 & 0 & 233 & 370 \\
\hline Sweden & 673 & 1,070 & 94 & 149 & 0 & 0 & 0 & 0 & 0 & $(1$ & 141 & --224 & --20 & -32 & 0 & 0 & 0 & 0 & 607 & 965 \\
\hline Switzerland & 1.208 & 1,921 & 0 & 0 & 0 & 0 & 0 & 0 & 0 & 0 & -470 & -747 & 140 & --223 & $(1$ & 0 & 0 & 0 & 598 & 950 \\
\hline UK. & 409 & 650 & 76 & 121 & 0 & 0 & 0 & 0 & 0 & 0 & -8 & --13 & 0 & 0 & 31 & 49 & 0 & 0 & 508 & 808 \\
\hline USA 'NY & 433 & 688 & 0 & 0 & 0 & 0 & 0 & 0 & 0 & 0 & -414 & -658 & 0 & 0 & 59 & 94 & 145 & 231 & 222 & 353 \\
\hline USA 'Pen & 253 & 402 & 0 & 0 & 0 & 0 & 0 & 0 & 0 & 0 & 0 & 0 & --14 & -22 & 61 & 97 & 108 & 172 & 408 & 649 \\
\hline USA Texas & 71 & 113 & 0 & 0 & 0 & 0 & 0 & 0 & 0 & 0 & 14 & 22 & -1 & .2 & 49 & 78 & 233 & 370 & 367 & 583 \\
\hline USA Florida & 157 & 250 & 0 & 0 & 0 & $(1$ & 0 & 0 & 0 & 0 & 340 & .541 & 0 & 0 & 67 & 107 & 224 & 356 & 108 & 172 \\
\hline
\end{tabular}

For nonpensioner households. the Italian figures should be regarded with particular caution. They represent optimistic assumptions about the likelihood and the level of awards to these households 
Tables $6.5 \mathrm{a}$ and $6.5 \mathrm{~b}$ provide a comparison of disposable income at the social assistance level, for all the family types, before and after housing costs. In a few countries. including Canada and the Nordic states, older people would not receive social assistance even if they had no contributory pension entitlement. Instead they received minimum. non-contributory 'citizen's pensions', and these are included in the tables in place of social assistance.

The first thing to note about these tables is that there were only five countries (Australia. Finland. Iceland, Japan and New Zealand) paying an independent social assistance benefit to an unemployed 17 year old single person. France and Luxembourg show negative amounts- because, despite having no income, such young people would be expected to pay some health costs in those countries. Japan had the highest benefit level for a 17 year old, but in practice it would be rare in Japan for young people of this age to be unemployed, out of education or training and not supported by their families.

The second point to note is the variation in the level of social assistance paid in the diffferent countries. Thus. for example for a couple with two children, before housing costs, it varied from an estimated $£ 1.068$ per month in Switzerland (Fribourg) to $£ 182$ per month in Portugal (and $£ 41$ per month in Greece which effectively has no social assistance scheme). For the same family after housing costs. the variation between countries was not as great, with Iceland providing the highest income ( $£ 644$ per month). compared with Portugal's $£ 21$ per month. Any social assistance payable was effectively cancelled out by housing costs for all families in Greece. for the single pensioner in Portugal, for the single 35 year old in Pennsylvania (USA), and for the single person and couple in Florida (USA) hence the negative amounts shown.

On this basis, for the couple with two children, the UK came fifteenth in the ranking of social assistance before housing costs and eighth after housing costs. This difference in rank order is a function of the fact that families on Income Support in the UK had almost all their housing costs covered by benefits. 
7'a66' 6.5a: Families on social assistance: net disposable income ( $£$ sterling purchasing power parity) per month (before housing costs), 1992

\begin{tabular}{|c|c|c|c|c|c|c|c|c|c|c|c|c|c|c|c|c|c|c|c|c|}
\hline & \multicolumn{2}{|c|}{$\begin{array}{l}\text { Single } \\
(17)\end{array}$} & \multicolumn{2}{|c|}{$\begin{array}{l}\text { Single } \\
(\mathbf{3 5})\end{array}$} & \multicolumn{2}{|c|}{$\begin{array}{l}\text { Single } \\
(\mathbf{6 8})\end{array}$} & \multicolumn{2}{|c|}{$\begin{array}{l}\text { Couple } \\
\text { (35) }\end{array}$} & \multicolumn{2}{|c|}{$\begin{array}{l}\text { Couple } \\
(68)\end{array}$} & \multicolumn{2}{|c|}{$\begin{array}{l}\text { Couple (35) } \\
+1 \text { child (3) }\end{array}$} & \multicolumn{2}{|c|}{$\begin{array}{l}\text { Couple (35) } \\
+1 \text { child (7) }\end{array}$} & \multicolumn{2}{|c|}{$\begin{array}{l}\text { Couple (35) } \\
+2 \text { eh }(7,14)\end{array}$} & \multicolumn{2}{|c|}{$\begin{array}{l}\text { Lone parent (35) } \\
+ \text { I child (3) }\end{array}$} & \multicolumn{2}{|c|}{$\begin{array}{l}\text { Lone parent } \\
\text { (35) }+1 \text { child } \\
\text { (7) }\end{array}$} \\
\hline & & $\mathrm{S}$ & $£$ & S & $£$ & S & $£$ & $\mathbf{S}$ & $\mathfrak{1}$ & b & $£$ & $\mathrm{~S}$ & $£$ & $\mathbf{S}$ & $£$ & $\mathbf{S}$ & $\mathfrak{f}$ & $\$$ & $\mathfrak{E}$ & S \\
\hline Australia & 128 & 203 & 285 & 453 & 309 & 491 & 515 & 818 & 515 & 818 & 598 & 951 & 598 & 951 & 680 & 1,081 & 426 & 677 & 426 & 677 \\
\hline Austria & 0 & 0 & 182 & 289 & 212 & 337 & 247 & 393 & 288 & $45 \mathrm{~S}$ & 360 & 572 & 360 & 572 & 494 & 785 & 262 & 417 & 262 & 417 \\
\hline Belgium & 0 & 0 & 302 & 480 & 304 & 483 & 400 & 636 & 404 & 642 & 458 & 728 & 465 & 739 & 554 & 881 & 461 & 733 & 468 & 744 \\
\hline Canada & 0 & 0 & 203 & 323 & 485 & 771 & 465 & 739 & 791 & 1,258 & 572 & 909 & 566 & 900 & 676 & 1,075 & 507 & 806 & 501 & 797 \\
\hline Denmark & 0 & 0 & 368 & 585 & 319 & 507 & 557 & 886 & 639 & 1,016 & 612 & 973 & 602 & 957 & 665 & 1.057 & 502 & 798 & 491 & 781 \\
\hline Finland & 159 & 253 & 187 & 297 & 187 & 297 & $31 \mathrm{~S}$ & 506 & 426 & 677 & 501 & 797 & 438 & 696 & 580 & 887 & 566 & 900 & 362 & 576 \\
\hline Prance & $\therefore 15$ & -24 & 170 & 270 & 277 & 440 & 235 & 374 & 493 & 784 & 271 & 170 & 296 & 471 & 377 & 599 & 343 & 545 & ${ }^{2} 60$ & 413 \\
\hline Germany & 0 & 0 & 141 & 224 & 170 & 270 & 258 & 410 & 309 & 491 & 336 & 534 & 350 & 556 & 477 & 758 & 307 & 488 & 233 & 370 \\
\hline Greece & 0 & 0 & 30 & 48 & 38 & 60 & 30 & 48 & 76 & 121 & 33 & 52 & 33 & 52 & $4 \mathrm{i}$ & 65 & 38 & 60 & 38 & 60 \\
\hline Iceland & 44 & 70 & 461 & 733 & 494 & 785 & 620 & 986 & 620 & 986 & 711 & 1,130 & 711 & 1,130 & 823 & 1,308 & 590 & 938 & 590 & 938 \\
\hline Ireland & 0 & 0 & 221 & 351 & 281 & 446 & 360 & 572 & 403 & 641 & 426 & 677 & 421 & 669 & 482 & 766 & 316 & 502 & 311 & 494 \\
\hline Italy' & 0 & 0 & 244 & 388 & 244 & 388 & 444 & 705 & 415 & 659 & 524 & 833 & 524 & 833 & 535 & 850 & 419 & 666 & 419 & 666 \\
\hline Japan & 281 & 447 & 258 & 410 & 246 & 391 & 397 & 631 & 373 & 593 & 497 & 790 & 512 & 814 & 663 & 1,054 & 430 & 684 & 446 & 709 \\
\hline Luxembourg & .3 & S & 405 & 644 & 405 & 644 & 542 & 862 & 545 & 866 & 646 & 1,027 & 646 & 1.027 & 760 & 1,208 & 509 & 809 & 509 & 809 \\
\hline Netherlands & 0 & 0 & 357 & 568 & 358 & 569 & 507 & 806 & 507 & 806 & 531 & 844 & 542 & 862 & 594 & 944 & 487 & 774 & 498 & 792 \\
\hline New Zealand & 149 & 237 & 723 & 355 & 322 & 512 & 371 & 590 & 493 & 784 & 467 & 742 & 465 & 739 & 496 & 789 & 395 & 628 & 392 & 623 \\
\hline Norway & 0 & 0 & 451 & 717 & 373 & 593 & 619 & 984 & 536 & 852 & 622 & 989 & 596 & 948 & 845 & 1,343 & 594 & 944 & 568 & 903 \\
\hline Portugal & 0 & & 158 & 251 & 78 & 124 & 158 & 251 & 156 & 248 & 169 & 269 & 170 & 270 & 182 & 289 & 169 & 269 & 170 & 270 \\
\hline Spain & 0 & & 196 & 312 & 131 & 208 & 225 & 358 & 223 & 356 & 266 & 423 & 262 & 417 & 292 & 464 & 241 & 383 & 237 & 377 \\
\hline Sweden & 0 & & 374 & 595 & 259 & 412 & 565 & 898 & 452 & 719 & 561 & 892 & 590 & 938 & 748 & 1,189 & 417 & 663 & 445 & 707 \\
\hline Switzerland & 0 & & 556 & 884 & 556 & 884 & 801 & 1,273 & 801 & 1,273 & 876 & 1,392 & 876 & 1,393 & 1,068 & 1.698 & 758 & 205 & 897 & 1,426 \\
\hline UK & 0 & & 184 & 293 & 248 & 394 & 289 & 459 & 385 & 612 & 402 & 639 & 407 & 647 & 516 & 820 & 318 & 506 & 323 & 514 \\
\hline USA NY & 0 & & 289 & 459 & 355 & 564 & 403 & 641 & 513 & 816 & 508 & 808 & 537 & 854 & 636 & 1,011 & 403 & 641 & 432 & 687 \\
\hline USA Pen & 0 & & 155 & 246 & 327 & 520 & 241 & 383 & 480 & 763 & 347 & 552 & 377 & 599 & 408 & 649 & 257 & 409 & 287 & 456 \\
\hline USA Texas & 0 & & 67 & 107 & 317 & 504 & 122 & 194 & 467 & 742 & 246 & 391 & 202 & 321 & 352 & 560 & 227 & 360 & 251 & 399 \\
\hline USA Florida & 0 & & 70 & III & 318 & 506 & 128 & 203 & 468 & 744 & 341 & 542 & 374 & 595 & 448 & 712 & 285 & 453 & 318 & 506 \\
\hline
\end{tabular}

For non-pensioner households, the Italian figures should be regarded with particular caution. They represent optimistic aissnmptiuns about the likelihood and the level of awards to these households 
Tble 6.56: Families on social assistance: net disposable income (i sterling purchasing power parity) per month (after housing costs). 1992

\begin{tabular}{|c|c|c|c|c|c|c|c|c|c|c|c|c|c|c|c|c|c|c|c|c|}
\hline & \multicolumn{2}{|c|}{$\begin{array}{l}\text { Single } \\
(17)\end{array}$} & \multicolumn{2}{|c|}{$\begin{array}{l}\text { Single } \\
(35)\end{array}$} & \multicolumn{2}{|c|}{$\begin{array}{l}\text { Single } \\
(68)\end{array}$} & \multicolumn{2}{|c|}{$\begin{array}{l}\text { Couple } \\
(35)\end{array}$} & \multicolumn{2}{|c|}{$\begin{array}{l}\text { Couple } \\
(68)\end{array}$} & \multicolumn{2}{|c|}{$\begin{array}{l}\text { Couple (35) } \\
+ \text { I child (3) }\end{array}$} & \multicolumn{2}{|c|}{$\begin{array}{l}\text { Couple (35) } \\
+\quad \text { child (7) }\end{array}$} & \multicolumn{2}{|c|}{$\begin{array}{l}\text { Couple (35) } \\
+2 \text { eh }(\mathbf{7 , 1 4})\end{array}$} & \multicolumn{2}{|c|}{$\begin{array}{l}\text { Lone parent (35) } \\
\quad+1 \text { child (3) }\end{array}$} & \multicolumn{2}{|c|}{$\begin{array}{c}\text { Lone parent } \\
\text { (35) }+1 \text { child } \\
\left({ }^{7}\right)\end{array}$} \\
\hline & $£$ & S & $£$ & $\$$ & $£$ & $\$$ & $£$ & $S$ & $£$ & $\$$ & $\mathfrak{£}$ & $\$$ & $£$ & $\$$ & $\mathfrak{f}$ & $\$$ & $£$ & S & $£$ & $\$$ \\
\hline Australia & 102 & 162 & 227 & 361 & 246 & 391 & 411 & 653 & 411 & 653 & 477 & 758 & 477 & 758 & 543 & 863 & 342 & 544 & 342 & 544 \\
\hline Austria & 0 & & 82 & 289 & 212 & 337 & 247 & 393 & 288 & 458 & 360 & 572 & 360 & 572 & 494 & 785 & 262 & 416 & 262 & 416 \\
\hline Belgium & 0 & & 171 & 272 & 173 & 275 & 237 & 377 & 241 & 383 & 295 & 469 & 301 & 479 & 372 & 591 & 298 & 474 & 305 & 485 \\
\hline Canada & 0 & & 38 & 60 & 180 & 286 & 300 & 476 & 486 & 773 & 368 & 585 & 362 & 576 & 432 & 687 & 303 & 481 & 297 & 472 \\
\hline Denmark & 0 & & 198 & 315 & 265 & 421 & 350 & 556 & 546 & 868 & 468 & 744 & 458 & 728 & 488 & 776 & 372 & 591 & 361 & 574 \\
\hline Finland & 159 & 252 & 87 & 297 & 187 & 297 & 318 & 506 & 426 & 677 & 501 & 796 & 438 & 696 & 580 & 922 & .566 & 900 & 362 & 576 \\
\hline France & $\ldots 15$ & -24 & 80 & 286 & 286 & 455 & 244 & 388 & $5(1.3$ & 800 & 286 & 455 & 311 & 494 & 398 & 633 & 347 & 552 & 275 & 437 \\
\hline Germany & 0 & & 141 & 224 & 170 & 270 & 258 & 410 & 309 & 491 & 336 & 534 & 350 & 556 & 477 & 758 & 307 & 488 & 233 & 370 \\
\hline Greece & 0 & & -31 & -49 & 31 & 49 & -68 & --108 & -34 & -54 & 64 & 102 & $\cdots 64$ & -102 & -103 & -_164 & 60 & .95 &. .60 & $\because .95$ \\
\hline Iceland & 44 & 70 & 294 & 467 & 313 & 500 & 452 & 719 & 452 & 719 & 543 & 863 & 543 & 863 & 644 & L024 & 418 & 665 & 410 & 652 \\
\hline Ireland & 0 & & 174 & 277 & 234 & 372 & 301 & 479 & 345 & 548 & 372 & 591 & 367 & 583 & 433 & 688 & 277 & 440 & 272 & 4.32 \\
\hline Italy' & 0 & & 199 & 316 & 139 & 221 & 267 & 424 & 139 & 221 & 326 & 518 & 326 & 518 & 355 & 564 & 275 & 437 & 275 & 437 \\
\hline japan & 281 & 447 & 192 & 305 & 180 & ${ }^{2} 86$ & 303 & 482 & 279 & 444 & 403 & 641 & 418 & 665 & 460 & 731 & 336 & 534 & 352 & 560 \\
\hline Luxembourg & $\cdot 3$ & 5 & 298 & 474 & 298 & 474 & 389 & 618 & 392 & 623 & 493 & 784 & 493 & 784 & 577 & 917 & 356 & 566 & 356 & 566 \\
\hline Netherlands & 0 & & 268 & 426 & 269 & 428 & 435 & 692 & 415 & 660 & 460 & 731 & 471 & 749 & 496 & 788 & 396 & 659 & 407 & 657 \\
\hline New Zealand & 149 & 237 & 115 & 183 & 197 & 313 & 219 & 348 & 321 & 510 & 297 & 472 & 294 & 467 & 313 & 498 & 239 & 380 & 236 & 375 \\
\hline Norway & 0 & & 212 & 337 & 212 & 337 & 332 & 528 & 332 & 528 & 463 & 736 & 437 & 695 & 546 & 868 & 435 & 692 & 409 & 650 \\
\hline Portugal & 0 & & 78 & 124 & 2 & 3 & 24 & 38 & 23 & 36 & 35 & 55 & 9 & 14 & 21 & 33 & 35 & 56 & 36 & 57 \\
\hline Spain & 0 & & 136 & 216 & 131 & 208 & 165 & 262 & 163 & 259 & 206 & 327 & 202 & 321 & 233 & 370 & 181 & 288 & 177 & 281 \\
\hline Sweden & 0 & & 203 & 322 & 238 & 378 & 348 & 543 & 427 & 679 & 442 & 703 & 471 & 748 & 607 & 965 & 298 & 474 & 326 & 518 \\
\hline Switzerland & 0 & & 256 & 407 & 256 & 407 & 416 & 661 & 416 & 661 & 492 & 782 & 492 & 782 & 598 & 951 & 373 & 593 & 513 & 815 \\
\hline UK. & 0 & & 180 & 286 & 244 & 389 & 281 & 447 & 377 & 599 & 394 & 626 & 399 & 634 & 508 & 808 & 314 & 499 & 319 & 507 \\
\hline USA NY & 0 & & 1 & --16 & 65 & 103 & 50 & 79 & 161 & 256 & 155 & 246 & 185 & 294 & 222 & 352 & 50 & 79 & 80 & 127 \\
\hline USA Pen & 0 & & 155 & 246 & 327 & 520 & 241 & 383 & 480 & 763 & 347 & 552 & 377 & 599 & 408 & 649 & 257 & 409 & 287 & 456 \\
\hline USA Texas & 0 & & 83 & 132 & 206 & 328 & 138 & 219 & $36(1$ & 572 & 252 & 401 & 219 & 348 & 367 & 583 & 222 & 353 & 246 & 391 \\
\hline USA Florida & 0 & & -176 & 280 & 72 & 114 & -125 & 199 & 215 & 342 & 88 & 140 & 121 & 192 & 108 & 171 & 32 & 51 & 65 & 103 \\
\hline
\end{tabular}

For non-pensioner households, the Italian figures should be regarded with particular caution, They represent optimistic assumptions about the likelihood and the level of awards to these households 
So far, the analysis has concentrated on the relative level of social assistance paid to couples with two children. Scrutiny of the tables, however, reveals that each country's relative position changes with the type of family considered. Thus the UK. for example, comes eighth after housing costs for a couple with two children, but twelfth for a childless couple. This variation occurs because countries treat different types of families differently that is, the implied equivalence scales in their benefit systems vary. Tables $6.6 \mathrm{a}$ and $6.6 \mathrm{~b}$ provide a representation of the implied equivalence scales in each country's social assistance system, before and after housing costs. In these tables, the assistance paid to a couple without children is set at 100 for each country: thus it is possible to compare the relative treatment of other family types compared with a childless couple.

First, it is interesting to compare the treatment of childless single people and couples above and below pension age. Most countries provided relatively larger assistance benefits to people over retirement age - Canada, France, Greece and the USA were notably more generous to people above pension age than to childless couples below pension age. Other countries did not vary their social assistance payments between those below and above pension age - including Belgium, Italy and Finland (for single people). Luxembourg, Netherlands and Switzerland. There were a few countries that appeared to pay higher benefits to working-age singles and couples than to pensioners. These included Denmark and Spain (for singles), Italy, Japan, Norway, Portugal and Sweden, though in Japan higher benefits are paid to people over 70. On the face of it. these differences in payments to younger and older people without children do not appear to follow any obvious pattern, though they may be related to the level of benefits available from old-age insurance pensions. Certainly they appear to represent a valuation by each country of the relative needs or deserts of younger and older childless people dependent on social assistance.

There was considerable variation in the level of benefit paid to an unemployed single person compared with an unemployed couple. Before housing costs, a single person in Canada. for example. received 44 per cent of the benefit paid to a couple. and in Australia, Germany, Italy and two of the US States, 55 per cent of that of a couple. There was no difference in the treatment of single people and couples in Greece and Portugal. and in Spain the single person received 87 per cent of the amount paid to a couple.

Turning to couples with children, we again see considerable variations in the treatment of children. Thus before housing costs Austria (Salzburg) paid an extra 46 per cent for a three year old. in Finland the extra amount was 58 per cent, and in two of the US states benefit increased by more than 100 per cent (but in their case the amounts paid for a childless couple were very low). By contrast, before housing costs. Sweden paid less for a couple with a three year old and Norway nearly the same amount. For two children, the extra amount paid varied from 251 per cent in Florida (from a very low base), 100 per cent in Austria, 85 per cent in Germany and 79 per cent in the U.K, to only 17 per cent in the Netherlands. 19 per cent in Denmark and 15 per cent in Portugal. Comparing the ratios for a couple with a three year old and a seven year old enables us to examine whether the amounts paid in social assistance vary with those ages. Again practices differed. A number of countries did pay higher benefits for children of different ages, but of those that did, about half paid more for a three year old and half more for a seven year old. These variations were not always the result of differences in the benefit scales: they could also be the consequence of school costs assumed for the seven year old, or exemption from health charges for the three year old.

Moving to the treatment of lone parents with children, the general pattern was for lone parents on social assistance to receive higher amounts than childless couples. but lower amounts than couples with the same number of children. However there were some exceptions to this pattern. Thus, in a number of countries, including, for 
example, Australia, Denmark, Ireland. Iceland. Italy and Sweden, lone parents received less than childless couples (before housing costs). In Finland. France and Greece. on the other hand, the lone parent with a three year old received more in social assistance than a couple with a child of the same age.

$T / d$ 6.6o: Implied equivalence scale of social assistance (before housing costs), couple $(35)=100$. 1992

\begin{tabular}{|c|c|c|c|c|c|c|c|c|c|c|}
\hline & $\begin{array}{l}\text { Single } \\
(17)\end{array}$ & $\begin{array}{l}\text { Single } \\
(\mathbf{3 5})\end{array}$ & $\begin{array}{l}\text { Single } \\
(\mathbf{6 8})\end{array}$ & $\begin{array}{c}\text { Couple } \\
\text { (35) }\end{array}$ & $\begin{array}{c}\text { Couple } \\
(68)\end{array}$ & $\begin{array}{l}\text { Couple } \\
(\mathbf{3 5})+ \\
\text { I child } \\
(3)\end{array}$ & $\begin{array}{l}\text { Couple } \\
(35) \\
\text { I child } \\
(7)\end{array}$ & $\begin{array}{c}\text { Couple } \\
(35)+ \\
2 \text { ch } \\
(7.14)\end{array}$ & $\begin{array}{l}\text { Lone } \\
\text { parent } \\
(35)+ \\
1 \text { child } \\
(3)\end{array}$ & $\begin{array}{c}\text { Lone } \\
\text { parent } \\
(\mathbf{3 5})+ \\
1 \text { child } \\
(7)\end{array}$ \\
\hline Australia & 25 & 55 & 60 & 100 & 100 & 116 & 116 & 137 & 83 & 83 \\
\hline Austria & 0 & 74 & 86 & I00 & 117 & 146 & 146 & 200 & 106 & 106 \\
\hline Belgium & 0 & 75 & 76 & 100 & 101 & 115 & 116 & 139 & 115 & 117 \\
\hline Canada & 0 & 44 & 104 & 100 & 170 & 123 & 122 & 145 & 109 & 108 \\
\hline Denmark & 0 & 66 & 57 & 100 & 115 & 110 & 108 & 119 & 90 & 88 \\
\hline Finland & 50 & 59 & 59 & 100 & 134 & 150 & 138 & 143 & 178 & 114 \\
\hline France & -6 & 72 & 118 & 100 & 210 & 115 & 126 & 161 & 146 & 111 \\
\hline Germany & 0 & 55 & 66 & 100 & 120 & 130 & 136 & 185 & 119 & 91 \\
\hline Greece & 0 & 100 & 127 & 100 & 253 & 111 & III & 138 & 126 & 126 \\
\hline Iceland & & 74 & SO & 100 & 100 & 115 & 115 & 133 & 95 & 95 \\
\hline Ireland & 0 & 61 & 78 & 100 & 112 & 118 & 117 & 134 & 88 & 87 \\
\hline Italy' & 0 & 55 & 55 & 100 & 93 & 118 & 118 & 120 & 94 & 94 \\
\hline Japan & 71 & 65 & 62 & 100 & 94 & 125 & 129 & 167 & 108 & 112 \\
\hline Luxembourg & -1 & 75 & 75 & 100 & 101 & 119 & 119 & 140 & 94 & 94 \\
\hline Netherlands & 0 & 70 & 71 & 100 & 100 & 105 & 107 & 117 & 96 & 98 \\
\hline New Zealand & 40 & 60 & 87 & 100 & 133 & 126 & 125 & 134 & 106 & 106 \\
\hline Norway & 0 & 73 & 60 & 100 & 87 & 101 & 96 & 137 & 96 & 92 \\
\hline Portugal & 0 & 100 & 50 & 100 & 99 & 107 & 107 & 115 & 107 & 107 \\
\hline Spain & 0 & 87 & 58 & 100 & 99 & 118 & 116 & 130 & 107 & 105 \\
\hline Sweden & 0 & 66 & 46 & 100 & 80 & 99 & 104 & 132 & 74 & 79 \\
\hline Switzerland & 0 & 69 & 69 & 100 & 100 & 109 & 109 & 133 & 95 & 112 \\
\hline UK. & 0 & 64 & 86 & 100 & 133 & 139 & 141 & 179 & 110 & 112 \\
\hline USA NY & 0 & 72 & 88 & 100 & 120 & 126 & 133 & 158 & 100 & 107 \\
\hline USA Pen & 0 & 64 & 136 & 100 & 200 & 144 & 157 & 169 & 107 & 119 \\
\hline USA Texas & 0 & 55 & 261 & 100 & 384 & 202 & 166 & 289 & 186 & 206 \\
\hline USA Florida & 0 & 55 & 249 & 100 & 367 & 267 & 293 & 361 & 223 & 249 \\
\hline
\end{tabular}

For non-pensioner households, the Italian fi ${ }^{g}$ ures should be regarded with particular caution. They represent optimistic assumptions about the likelihood and the level of awards to these households 
Table 6.66: Implied equivalence scale of social assistance (after housing costs), couple(35) -= 100. 1992

\begin{tabular}{|c|c|c|c|c|c|c|c|c|c|c|}
\hline & $\begin{array}{l}\text { Single } \\
(17)\end{array}$ & $\begin{array}{l}\text { Single } \\
(35)\end{array}$ & $\begin{array}{c}\text { Single } \\
(\mathbf{6 8})\end{array}$ & $\begin{array}{l}\text { Couple } \\
\text { (35) }\end{array}$ & $\begin{array}{c}\text { Couple } \\
\text { (68) }\end{array}$ & $\begin{array}{c}\text { Couple } \\
(35)+ \\
\text { I child } \\
\left(^{3}\right)\end{array}$ & $\begin{array}{c}\text { Couple } \\
(35)+ \\
1 \text { child } \\
\left({ }^{7}\right)\end{array}$ & $\begin{array}{c}\text { Couple } \\
(35)+ \\
2 \text { eh } \\
(7,14)\end{array}$ & $\begin{array}{c}\text { Lone } \\
\text { parent } \\
(35)+ \\
\text { I child } \\
\text { (3) }\end{array}$ & $\begin{array}{l}\text { Lone } \\
\text { parent } \\
(35)+ \\
\text { I child } \\
(7)\end{array}$ \\
\hline Australia & 75 & 55 & 60 & 100 & 100 & 116 & 116 & 132 & 83 & 83 \\
\hline Austria & 0 & 74 & 86 & 100 & 117 & 146 & 146 & 200 & 106 & 106 \\
\hline Belgium & 0 & 72 & 73 & 100 & 102 & 125 & 127 & 157 & 136 & 129 \\
\hline Canada & 0 & 13 & 60 & 100 & 162 & 123 & 121 & 144 & 101 & 99 \\
\hline Denmark & 0 & 56 & 76 & 100 & 156 & 134 & 131 & 139 & 106 & 103 \\
\hline Finland & 50 & 59 & 59 & 100 & 134 & 158 & 138 & 183 & 178 & 114 \\
\hline France & -6 & 73 & 117 & 100 & 206 & 117 & 127 & 163 & 142 & 113 \\
\hline Germany & 0 & 55 & 66 & 100 & 120 & 130 & 136 & 185 & 119 & 91 \\
\hline Greece & 0 & 47 & 46 & 100 & 51 & 95 & 95 & $15 \$$ & 88 & 88 \\
\hline Iceland & to & 65 & 69 & 100 & 100 & 121) & 120 & 142 & 92 & 91 \\
\hline Ireland & 0 & 58 & 78 & 100 & 114 & 123 & 122 & 144 & 92 & 90 \\
\hline Italy' & 0 & 51 & 51 & 100 & 93 & 119 & 119 & 122 & 94 & 94 \\
\hline Japan & 9.3 & 64 & 60 & 100 & 92 & 133 & 138 & 152 & 111 & 116 \\
\hline Luxembour $^{\mathrm{g}}$ & 1 & 77 & 77 & 100 & 101 & 127 & 127 & 148 & 92 & $9^{2}$ \\
\hline Netherlands & 0 & 62 & 62 & 100 & 95 & 106 & 108 & 114 & 91 & 93 \\
\hline New Zealand & 68 & 52 & 90 & .100 & 147 & 136 & 135 & 143 & 109 & 108 \\
\hline Norway & 0 & 64 & 64 & 100 & 100 & 139 & 131 & 164 & 131 & 136 \\
\hline Portugal & 0 & 323 & -9 & 100 & 94 & 145 & 38 & 87 & 145 & 149 \\
\hline Spain & 0 & 82 & 79 & 100 & 98 & 125 & 122 & 141 & 110 & 107 \\
\hline Sweden & 0 & 58 & 68 & 100 & 123 & '127 & 135 & 174 & 85 & 94 \\
\hline Switzerland & 0 & 62 & 62 & 100 & 100 & 118 & 118 & 144 & 90 & 123 \\
\hline UK & 0 & 64 & 87 & 100 & 134 & 140 & 142 & 181 & 112 & 114 \\
\hline USA NY & 0 & $-I$ & 130 & 100 & 320 & 309 & 367 & 441 & 100 & 159 \\
\hline USA Pen & 0 & 64 & 136 & 100 & 200 & 144 & 157 & 169 & 107 & 119 \\
\hline USA Texas & 0 & 60 & 150 & 100 & 262 & 183 & 159 & 267 & 161 & 179 \\
\hline USA Florida & 0 & 141 & -57 & 100 & -172 & -70 & -97 & -86 & 26 & 52 \\
\hline
\end{tabular}

For non-pensioner households, the Italian figures should be regarded with particular caution. They represent optimistic assumptions about the likelihood and the level of awards to these households

Given all this variation in the level of social assistance paid to families of different types, it is not easy to draw conclusions about the overall comparative income levels of recipients of social assistance in different countries. However, an attempt is made at an overall ranking in Tables $6.7 \mathrm{a}$ and $6.7 \mathrm{~b}$. These rankings are derived by taking the total amounts, in purchasing power parity £sterling, paid to all the family types except the single 17 year old. This total is then expressed as a proportion of the mean for all countries. The advantage of this method is that it not only gives a ranking of countries, but also provides an indication of dispersion. Clearly a composite figure for all the family types takes no account of the prevalence of different types of family among social assistance recipients in different countries - a prevalence which may in some cases be influenced by behavioural responses to the policy structures under examination. Nor can it represent the variation for different family types. It is subject to all the caveats al ready mentioned, including housing cost assumptions_discretionary benefit levels in some countries, and the limitations of purchasing power parities. Nevertheless, the composite figure does provide a useful indicator of the overall effect of policy. The average for each country is presented as a percentage distance from the mean for all the family types. before and after housing costs. Those with negative figures were thus below the mean.

Before housing costs. Switzerland (Fribourg) was clearly an outlier. with the level of social assistance paid to these nine families being close to double the mean. This is possibly an artefact of the estimation necessary to judge what families might receive in a discretionary system. The U.K. social assistance level came out as 19 per cent below the mean. However, probably a more reliable comparison is the ranking after housing costs. On this scale, Iceland had the highest level of social assistance, at around 50 per cent above the mean, and headed a leading group containing the Nordic countries. Luxembourg. the Netherlands and Australia, all with levels more than 20 per cent above the mean. Italy too appears in this group, but, as has been 
emphasised, the figures for non-pensioner households in particular may be less accurate for Italy than for other countries. Next comes a group of countries led by the UK and including the USA (New York), Japan, France, Canada and Germany. Finally there is a third group, all with social assistance levels more than ten per cent below the mean. including Belgium. New Zealand, the three other US states and the other southern European countries. Greece, which as we have seen has no general or major categorical social assistance programmes, stands out at the bottom of the ranking.

There are a considerable number of changes in ranking before and after housing costs: after housing costs, Canada. Belgium and New Zealand move down the ranking and Finland. Germany, Austria, France and the UK improve their positions.

Table 6.7a, Social assistance: percentage ctifi'erence from the mean - all cases before housing costs

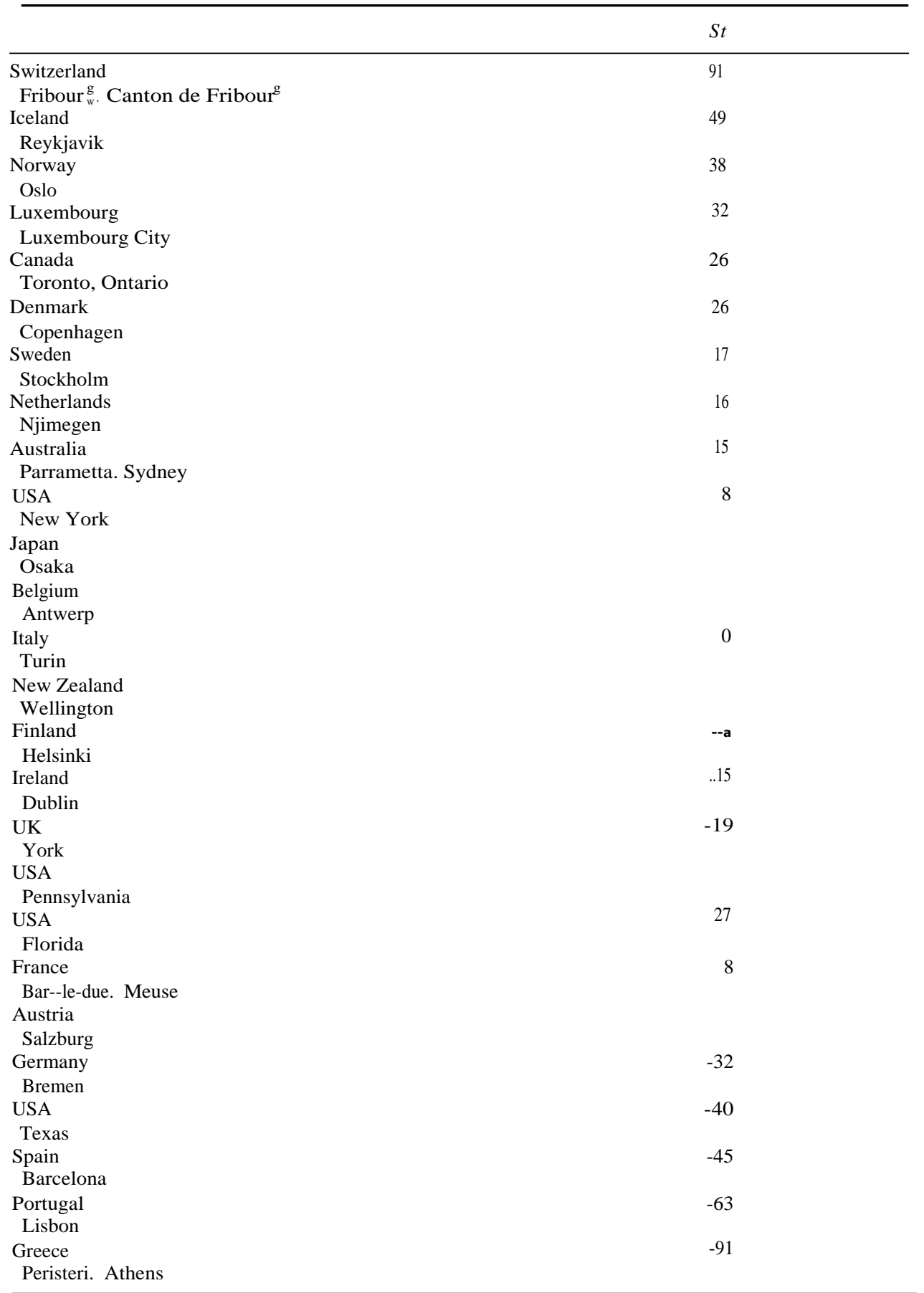




\begin{tabular}{|c|c|}
\hline & $\%$ \\
\hline $\begin{array}{l}\text { Iceland } \\
\text { Reykjavik }\end{array}$ & 50 \\
\hline $\begin{array}{l}\text { Switzerland } \\
\text { Fribourg. Canton de Fribourg }\end{array}$ & 41 \\
\hline $\begin{array}{l}\text { Luxembourg } \\
\text { Luxembour }{ }^{\mathrm{g}} \text { City }\end{array}$ & 35 \\
\hline $\begin{array}{l}\text { Netherlands } \\
\text { Njimegen }\end{array}$ & 33 \\
\hline $\begin{array}{l}\text { Finland } \\
\text { Helsinki }\end{array}$ & 31 \\
\hline $\begin{array}{l}\text { Denmark } \\
\text { Copenhagen }\end{array}$ & \\
\hline $\begin{array}{l}\text { Italy } \\
\text { Turin }\end{array}$ & 28 \\
\hline $\begin{array}{l}\text { Australia } \\
\text { Ptarramatta. Sydney }\end{array}$ & 28 \\
\hline $\begin{array}{l}\text { Norway } \\
\text { Oslo }\end{array}$ & is \\
\hline $\begin{array}{l}\text { Sweden } \\
\text { Stockholm }\end{array}$ & 24 \\
\hline $\begin{array}{l}\text { UK } \\
\text { York }\end{array}$ & it \\
\hline $\begin{array}{l}\text { Japan } \\
\text { Osaka }\end{array}$ & 8 \\
\hline $\begin{array}{l}\text { USA } \\
\text { New York }\end{array}$ & 6 \\
\hline $\begin{array}{l}\text { France } \\
\text { Bar-le-due, Meuse }\end{array}$ & 4 \\
\hline $\begin{array}{l}\text { Ireland } \\
\text { Dublin }\end{array}$ & 2 \\
\hline $\begin{array}{l}\text { Canada } \\
\text { Toronto. Ontario }\end{array}$ & $\mathbf{i}$ \\
\hline $\begin{array}{l}\text { Austria } \\
\text { Salzbur }^{\mathrm{g}}\end{array}$ & \\
\hline $\begin{array}{l}\text { Germany } \\
\text { Bremen }\end{array}$ & $-a$ \\
\hline $\begin{array}{l}\text { Belgium } \\
\text { Antwerp }\end{array}$ & \\
\hline $\begin{array}{l}\text { New Zealand } \\
\text { Wellington }\end{array}$ & 18 \\
\hline $\begin{array}{l}\text { USA } \\
\text { Pennsylvania }\end{array}$ & .23 \\
\hline $\begin{array}{l}\text { Spain } \\
\text { Barcelona }\end{array}$ & 41 \\
\hline $\begin{array}{l}\text { USA } \\
\text { Florida }\end{array}$ & -64 \\
\hline $\begin{array}{l}\text { USA } \\
\text { Texas }\end{array}$ & -85 \\
\hline $\begin{array}{c}\text { Portugal } \\
\text { Lisbon }\end{array}$ & -90 \\
\hline $\begin{array}{l}\text { Greece } \\
\text { Peristeri. Athens }\end{array}$ & -319 \\
\hline
\end{tabular}

These comparisons of the level of social assistance have been based on purchasing power parities. In Table A6.3. at the end of the chapter. social assistance is also expressed as a proportion of average gross earnings, before housing costs and for two families only - the pensioner couple and the couple with two children. The results of these comparisons are, as would be expected given the discussion earlier about earnings data, to improve the relative levels of France. Sweden and Finland. Thus for the couple aged 68, Sweden moved from being below the average on the purchasing power parity ranking to among the top countries on the proportion of average earnings rankings, and for the couple with two children it moved from fourth to first place. However, apart from these three countries the relative level of the countries remained reasonably stable. whichever comparison was used. 
Another method of comparing the level of social assistance is to compare it with the net disposable incomes of similar families in work. This is investigated for working age families in Chapter Seven as part of the exploration of incentives and unemployment traps. The analysis here is restricted to the single and couple pensioners. Tables $6.8 \mathrm{a}$ and $6.8 \mathrm{~b}$ provide data on the pensioner replacement ratios for each country, before and after housing costs -- that is. the ratio of the net disposable income of the pensioner receiving social assistance to the net disposable income of a single working person, or one earner couple, on average earnings. The ratio is therefore a relative measure of the level of living of pensioners on social assistance. The higher the ratio, the closer the incomes of pensioners on social assistance are to those of similar people in work.

Before housing costs. the ratios vary for a single pensioner from 62 per cent in Switzerland (Fribourg) to seven per cent in Greece. and. for a couple, from 89 per cent in Switzerland to 12 per cent in Greece. The UK, at 28 per cent for a single person and 42 per cent for a couple, comes well down in the ranking. After housing costs, in most countries. pensioners" replacement ratios improve because housing benefits are of more help to social assistance recipients - the UK, for example, moves up the league table for this reason.

Table 6.8a: Pensioners replacement ratio (net disposable income on social assistance as percentage of net disposable income on average earnings) (before housing costs)

\begin{tabular}{|c|c|c|}
\hline & Single person & Couple \\
\hline Australia & 34 & 54 \\
\hline Austria & 30 & 40 \\
\hline Belgium & 39 & 47 \\
\hline Canada & 45 & 69 \\
\hline Denmark & 47 & 81 \\
\hline Finland & 23 & 54 \\
\hline France & 42 & 71 \\
\hline Germany & 21 & 34 \\
\hline Greece & 7 & 12 \\
\hline Ireland & 37 & 47 \\
\hline Italy & 42 & 52 \\
\hline Japan & 24 & 33 \\
\hline Luxembour $^{\mathrm{g}}$ & 43 & 52 \\
\hline Netherlands & 58 & 77 \\
\hline New Zealand & 39 & 61 \\
\hline Norway & 45 & 62 \\
\hline Portugal & 22 & 43 \\
\hline Spain & .17 & 28 \\
\hline Sweden & 40 & 71) \\
\hline Switzerland & 62 & 89 \\
\hline UK & 28 & 42 \\
\hline USA N Y & 33 & 50 \\
\hline USA Pen & 32 & 49 \\
\hline USA Texas & 29 & 47 \\
\hline USA Florida & 32 & 53 \\
\hline
\end{tabular}


Table 6.156: Pensioners replacement ratio (net disposable income on social assistance as percentage net disposable income on average earnings) (alter housing costs)

\begin{tabular}{|c|c|c|}
\hline & Single person ${ }^{\circ} \mathrm{E}>$ & Couple Ni \\
\hline Australia & 36 & 57 \\
\hline Austria & 46 & 80 \\
\hline Belgium & & 35 \\
\hline Canada & 23 & 57 \\
\hline Denmark & 55 & 100 \\
\hline Finland & & 109 \\
\hline ]ranee & 48 & 8 \\
\hline Germany & 28 & 46 \\
\hline Greece & & 8 \\
\hline Ireland & 38 & 53 \\
\hline ]tale & 43 & 54 \\
\hline Japan & 23 & 34 \\
\hline Luxembourg & 36 & 44 \\
\hline Netherlands & 53 & 78 \\
\hline New Zealand & 32 & 58 \\
\hline Norway & 34 & 54 \\
\hline Portugal & -1 & 10 \\
\hline Spain & 19 & 22 \\
\hline Sweden & 55 & 110 \\
\hline Switzerland & 51 & 91 \\
\hline U.K & 31 & 49 \\
\hline USA NY & 10 & 26 \\
\hline USA Pen & & 49 \\
\hline USA Texas & $? 5$ & 50 \\
\hline USA Florida & 9 & 34 \\
\hline
\end{tabular}

One final way of examining the level of social assistance is to compare the relationship between the net disposable resources of families receiving social assistance and those receiving social insurance benefits. The analysis is presented in Tables 6.9a and 6.96. with the relationship between the disposable income of families in the two situations expressed as a percentage ratio. These ratios could be described as a representation of the 'contributions trap' in each country. Beneficiaries in those countries with high ratios were receiving little more in exchange for their contributions than they would if they had not -made contributions and were therefore not entitled to insurance benefits. The tables also show what would be the impact to the incomes of families when entitlement to insurance benefits cease (for example, as a result of being unemployed for a long period of time). and people have to fall back on social assistance.

Looking at the situation before housing costs (Table 6.9a). we see that in Australia and New Zealand the ratio was 100 per cent. because there are no social insurance benefits. The ratio for the other countries varied considerably. both between countries and within and between countries by the type of family. The results for the US states were heavily affected by the assumptions about health and housing costs. Payments for health care and insurance, for example. can be so large that many people on low incomes cannot afford them. The specified package, nevertheless. includes them. resulting in somewhat artificial negative incomes. Among the other countries, the members of the Nordic group had particularly high ratios -- indeed for the couple with two children in Denmark, Norway and Sweden, the social assistance levels exceeded the social insurance Ievels. The UK and Ireland also had high ratios.

The countries with the biggest gaps between the level of their social insurance payments and their social assistance payments were the continental European countries. There were interesting differences in the ratios for people below and above retirement age. In the majority of countries, social assistance levels were closer to social insurance levels for non-pensioners than pensioners - this is true of all the Nordic countries. Netherlands. Japan and Switzerland. In these countries, retirement insurance pensions are likely to be at a higher level than unemployment insurance, and in some cases older people without full insurance-based entitlements would be entitled to supplements which are income-tested less strictly than social 
assistance. In Canada. France and Portugal, on the other hand, social assistance levels appeared closer to social insurance levels for pensioner couples than nonpensioner couples. In general. the ratios after housing costs were higher than before housing costs because housing benefits w3-ere more generous to families on social assistance than social insurance. Indeed, only in Belgium. Luxembourg. Portugal and Spain were they lower (for a couple plus two children) and in many more countries the net disposable income on social assistance was more than or only a little less than net disposable income on social insurance.

Table 6.9a: Ratio of net disposable income on social assistance to net disposable income on social insurance (before housing costs)

\begin{tabular}{|c|c|c|c|c|c|c|}
\hline & $\begin{array}{c}\text { Single } \\
(\mathbf{3 5})\end{array}$ & $\begin{array}{c}\text { Single } \\
\text { (68) }\end{array}$ & $\begin{array}{c}\text { Couple } \\
\text { (35) }\end{array}$ & $\begin{array}{c}\text { Couple } \\
(68)\end{array}$ & $\begin{array}{c}\text { Couple }(35) \\
+2 \text { children } \\
(7.14)\end{array}$ & $\begin{array}{l}\text { Lone parent } \\
\qquad(35)+1 \\
\text { child }(7)\end{array}$ \\
\hline Australia & 100 & 100 & 100 & 100 & 100 & 100 \\
\hline Austria & 42 & 36 & 54 & 49 & 76 & 51 \\
\hline Belgium & 59 & 53 & 79 & 54 & 88 & 84 \\
\hline Canada & 30 & 83 & 62 & 97 & 75 & 65 \\
\hline Denmark & 83 & 94 & 101 & 92 & 108 & 90 \\
\hline Finland & 38 & 35 & 66 & 60 & 93 & 57 \\
\hline France & 35 & 49 & 47 & 84 & 65 & 46 \\
\hline Germany & 45 & 28 & 45 & 53 & 67 & 54 \\
\hline Greece & 15 & 7 & 14 & 13 & 16 & 17 \\
\hline Iceland & $\mathrm{n} . / \mathrm{a}$ & $\mathrm{Ma}$ & nia & $\mathrm{Ma}$ & nia & nia \\
\hline Ireland & 78 & 88 & 81 & 81 & 89 & 96 \\
\hline Italy & $\mathrm{n} / \mathrm{a}$ & $\mathrm{Ma}$ & nra & $\mathrm{n} \mathrm{a}$ & nia & $\mathrm{n} / \mathrm{a}$ \\
\hline Japan & 43 & 35 & 62 & 49 & 104 & 61 \\
\hline Luxembourg & 51 & 48 & 64 & 58 & 62 & 51 \\
\hline Netherlands & 78 & 57 & 102 & 57 & 102 & 94 \\
\hline New Zealand & 100 & 100 & 100 & 100 & 100 & 100 \\
\hline Norway & 83 & 77 & 107 & 79 & 114 & 73 \\
\hline Portugal & 45 & 45 & 45 & 83 & 49 & 69 \\
\hline Spain & 33 & 16 & 38 & 26 & 39 & 47 \\
\hline Sweden & 67 & 59 & 102 & 71 & 117 & 65 \\
\hline Switzerland & 84 & 81 & 120 & 92 & 100 & 102 \\
\hline UK & 99 & 75 & 96 & 82 & 94 & 96 \\
\hline USA NY & 84 & 78 & 183 & 75 & 165 & 173 \\
\hline USA Pen & 45 & 62 & 62 & 59 & 98 & 63 \\
\hline USA Texas & 21 & 76 & 26 & 77 & 56 & 50 \\
\hline USA Florida & 30 & 69 & 260 & 68 & -103 & -104 \\
\hline
\end{tabular}

Note: It was not possible to obtain the social insurance data for Iceland and Italy 
Table 6.91: Ratio of net disposable income on social assistance to net disposable income on social insurance (after housing costs)

\begin{tabular}{|c|c|c|c|c|c|c|}
\hline & $\begin{array}{c}\text { Single } \\
(35)\end{array}$ & $\begin{array}{l}\text { Single } \\
(\mathbf{6 8})\end{array}$ & $\begin{array}{c}\text { Couple } \\
\text { (35) }\end{array}$ & $\begin{array}{c}\text { Couple } \\
\text { (68) }\end{array}$ & $\begin{array}{l}\text { Couple }(35) \\
+2 \text { children } \\
\quad(7,14)\end{array}$ & $\begin{array}{c}\text { Lone parent } \\
\begin{array}{c}(35)+1 \\
\text { child (7) }\end{array}\end{array}$ \\
\hline Australia & 100 & 100 & 100 & 100 & 100 & 100 \\
\hline Austria & 97 & 61 & 236 & 121 & 305 & 158 \\
\hline Belgium & 45 & 39 & 69 & 42 & 83 & 78 \\
\hline Canada & 10 & 64 & 68 & 95 & 97 & 74 \\
\hline Denmark & 72 & 92 & 102 & 91 & 112 & 88 \\
\hline Finland & 78 & 67 & 123 & 95 & 118 & 76 \\
\hline France & 41 & 58 & 54 & 95 & 70 & 51 \\
\hline Germany & 114 & 41 & 76 & 89 & 96 & 122 \\
\hline Greece & -23 & 6 & -63 & 6 & -89 & $\therefore 49$ \\
\hline Iceland & $\mathrm{n} / \mathrm{a}$ & n'a & $\mathrm{n} / \mathrm{a}$ & nia & $\mathrm{n} / \mathrm{a}$ & $\mathrm{n} / \mathrm{a}$ \\
\hline Ireland & 81 & 85 & 80 & 79 & 94 & 102 \\
\hline Italy & $\mathrm{n} \mathrm{a}$ & n'a & $n ;\langle<t$ & $\mathrm{n} \mathrm{a}$ & $\mathrm{ma}$ & $\mathrm{n} / \mathrm{a}$ \\
\hline Japan & 49 & 36 & 82 & 58 & 173 & 76 \\
\hline Luxembourg & 43 & 41 & 56 & 50 & 55 & 42 \\
\hline Netherlands & 78 & 52 & 118 & 55 & 114 & 101 \\
\hline New Zealand & 106 & 100 & 103 & 100 & 102 & 103 \\
\hline Norway & 64 & 72 & 103 & 73 & 134 & 73 \\
\hline Portugal & 29 & 2 & 11 & 41 & 10 & 32 \\
\hline Spain & 25 & 18 & 31 & 20 & 34 & 40 \\
\hline Sweden & 57 & 78 & 116 & 97 & 143 & 66 \\
\hline Switzerland & 95 & 74 & 187 & 95 & 108 & 120 \\
\hline UK & 101 & 90 & 99 & 94 & 100 & 100 \\
\hline USA NY & 1 & 39 & -38 & 48 & -772 & --78 \\
\hline USA Pen & 45 & 62 & 62 & 59 & 98 & 63 \\
\hline USA Texas & 44 & 72 & 39 & 87 & 70 & 64 \\
\hline USA Florida & -1.600 & 34 & 61 & 50 & -14 & -23 \\
\hline
\end{tabular}

Note: It was not possible to obtain the social insurance data for Iceland and Italy

All the data discussed so far is based on the situation in 1992. In some countries there have been changes in social assistance arrangements since this date, quite apart from any uprating of benefits. It is not possible at this point to estimate the impact of any such changes on the relative value of benefits or benefit packages, but it is worth noting the key changes which have taken place. Table 6.10 summarises recent and prospective changes, based on information provided by our national informants.

Table 6.10: Changes in social assistance which might have affected the level of payments between 1992 and 1995

\begin{tabular}{|c|c|}
\hline Country & Changes \\
\hline \multirow[t]{4}{*}{ Australia } & $\begin{array}{l}\text { Since July } 1992 \text { it has been compulsory for employers to make superannuation } \\
\text { contributions for virtually all their employees. From March } 1993 \text { a new } \\
\text { structure of increased rates and variable rent thresholds has tar }{ }^{\text {g }} \text { eted rent } \\
\text { assistance to private renters with housing affordability problems. The family } \\
\text { payment system was rationalised and integrated in January } 1993 \text {. Family } \\
\text { allowance became Basic Family Payment, while FAS and additional } \\
\text { pension/allowance/benefit became Additional Family Payment. All family } \\
\text { payments are now paid to the primary carer, usually the mother. }\end{array}$ \\
\hline & $\begin{array}{l}\text { From March } 1993 \text { the jobs Education and Training (JET) scheme was } \\
\text { extended to widow pensioners and carer pensioners. }\end{array}$ \\
\hline & $\begin{array}{l}\text { From September } 1994 \text { a Home Care Allowance of S60 per fortnight is paid } \\
\text { direct to full-time carers of children in the home. }\end{array}$ \\
\hline & $\begin{array}{l}\text { From } 1995 \text { the income support test for couples will be partly individualised } \\
\text { and earnings disregards changed, plus a package of other work incentive } \\
\text { measures. }\end{array}$ \\
\hline
\end{tabular}


Table 6.f\{ $i$ : Changes in social assistance which might have affected the level of payments between 1992 and 1995 eontd)

\begin{tabular}{|c|c|}
\hline Country & Changes \\
\hline Austria & $\begin{array}{l}\text { The Federal Nursing Benefits Act } 1993 \text { has raised insurance based benefits for } \\
\text { persons requiring nursing care thus easing the burden on social assistance paid } \\
\text { by the provinces_. } \\
\text { In } 1994 \text { the limited powers of central government over social assistance were } \\
\text { removed and it became almost entirely a responsibility of the provinces. }\end{array}$ \\
\hline Befium & $\begin{array}{l}1992 \text { Abolition of previous residence condition. } \\
199.3 \text { Abolition of the permanent residence condition affecting the homeless. }\end{array}$ \\
\hline Canada & $\begin{array}{l}\text { The } 1992 \text { federal budget put a cap on the Canada Assistance Plan at } 5 t \text { until } \\
19945 \text { and this will have put pressure on provinces to reduce expenditures. } \\
\text { Also many provinces have made their social assistance two tiered. Frozen } \\
\text { benefits and enforced more rigid job search activities by employables'. } \\
\text { From } 1996197 \text { the Canada Assistance Plan will he replaced by a broader } \\
\text { Canadian Health and Social Transfer_under which provinces will have greater } \\
\text { authority on social assistance but have federal funding. Some hav=e already } \\
\text { reduced benefits. }\end{array}$ \\
\hline
\end{tabular}

Denmark Radical changes in payment structure from January ${ }^{\circ}$ 1994. Benefits became subject to tax and insurance contributions, but were substantially increased. Benefit linked to unemployment benefit, extra housing and children's allowance no longer payable, but assistance recipients have access to the normal rent subsidies and child care subsidies. Simpler, but disadvantages those with high housing costs.

Finland National scales of benefit have been phased in, and from 1994 all municipalities are required to pay only the higher "gross norm" at standardised national rates. From 1994 child allowance is treated as income and will he deducted from social assistance. Child over 18 living with parents granted a reduced allowance.

\begin{tabular}{ll}
\hline France & No changes directly affectin \\
& g social assistance \\
\hline Germany & Process of unification still going on - increase in dependency of one parents in
\end{tabular}
the new Lander on social assistance.

Changes introduced at the end of 1992 and the beginning of 1994. Age for older persons supplement raised from 60-64; increased powers to recover benefit from liable relatives. Reductions in future levels of unemployment benefit and assistance announced in Jan 1994. Asylum seekers excluded from social assistance since November 1993: now only entitled to benefits in kind or minimal cash payments. Long-term care insurance introduced in 1994. Proposals to reform Susialhillc in 1995.

\begin{tabular}{ll}
\hline Greece & Benefit for the non-insured elderly has increased \\
\hline Iceland & Since 1993, income-testing introduced into the pension system and incomes
\end{tabular}
related supplements expanded. Separate general housing benefit introduced in January 1995.

\begin{tabular}{ll}
\hline Ireland & Back-to-work allowances introduced to increase work incentives \\
\hline Italy & In 1993 the means test for the supplementary pension was changed from an
\end{tabular}
individual to a couple basis.

The reform of the health system launched in 1993 requires increased charges for drugs and treatment, with some increase in means testing as a result. The policy of the new Government on social assistance is not yet known, but attempts to curb pension levels may lead to increases in assistance claims.

\begin{tabular}{|c|c|}
\hline japan & No specific changes affecting social assistance \\
\hline Luxembourg & $\begin{array}{l}\text { In February } 1993 \mathrm{Rb} 4 \mathrm{G} \text { rates for single adults were increased by } 3.8 \% \text { and the } \\
\text { rate for the second adult in the household by } \mathrm{S} 2141 . \text { The level of maximum } \\
\text { housing allowance was increased_Insertion contracts, changes in the } \\
\text { availability for work test of mothers with children and other adjustments to } \\
\text { the means-test were introduced. }\end{array}$ \\
\hline Netherlands & $\begin{array}{l}\text { The Government stated that it expected purchasing power for people on the } \\
\text { social minimum to drop by three per cent during } 1994 \text {. } \\
\text { In } 1993 \text { lone parents with no children under } 6 \text { years became obliged to be } \\
\text { available for work_New revised assistance scheme, combining ASW and } \\
\text { RWW, introduced from January } 1996 \text {. Includes reduction in rates for single } \\
\text { people and lone parents. and more discretion. }\end{array}$ \\
\hline
\end{tabular}


Table 6.10: Changes in social assistance which might have affected the level of payments between 1992 and 1995 - (confer;

\begin{tabular}{|c|c|}
\hline Country & Changes \\
\hline New Zealand & $\begin{array}{l}\text { Accommodation supplement introduced in 1994. replacing income related rents } \\
\text { in the public sector and the flat-rate accommodation benefit for people in the } \\
\text { private housing sector }\end{array}$ \\
\hline Norway & No spec changes affecting social assistance \\
\hline Portugal & Plans for reform but none implemented in period \\
\hline Spain & $\begin{array}{l}\text { No changes reported in regional InSreao Minima. In } 1994 \text { condition of } \\
\text { entitlement to Unemployment Assistance restricted. }\end{array}$ \\
\hline Sweden & $\begin{array}{l}\text { Since 1993, unemployment and sickness contribution have been payable } \\
\text { (previously paid for out of taxation). Thus social assistance recipients now not } \\
\text { covered. } \\
\text { Discussions continuing about national social assistance standard rates. }\end{array}$ \\
\hline Switzerland & None reported \\
\hline Turkey & None reported \\
\hline United Kin ${ }^{g}$ dom & $\begin{array}{l}\text { The Child Support Act began operating from April } 1993 \text { and is designed to } \\
\text { ensure that absent fathers contribute to the financial support of their children } \\
\text {-- contributions based on a strict formula with no disregard. so does not affect } \\
\text { the incomes of lone parents receiving Income Support. } \\
\text { in } 1993 \text { care clement of Income Support for people in residential ca"e } \\
\text { transferred to local authorities. } \\
\text { From October } 1994 \text { families claiming in-work benefits were able to benefit } \\
\text { from an offset of formal child-care charges of up to } £ 40 \text { per week. } \\
\text { Packa }{ }^{g} \text { of work incentive schemes introduced commencin }{ }^{g} \text { from } 1995 \text {. From } \\
1996 \text { will include the } 7 \text { obseeker`s Allowance, which replaces Unemployment } \\
\text { Benefit and Income Support for the unemployed. }\end{array}$ \\
\hline USA & $\begin{array}{l}\text { Welfare is a high profile issue and the Administration and others have } \\
\text { proposals for reform mainly aimed at work incentives and reducing the welfare } \\
\text { rolls. No national changes implemented so far. but some states have begun to } \\
\text { reduce provision. }\end{array}$ \\
\hline
\end{tabular}

With the possible exception of Denmark, which has restructured its scales in 1994, there do not appear to have been fundamental reforms that would. by 199.5. have altered the general picture of the level of social assistance presented in this chapter. although changes to the RMG equivalence scale in Luxembourg and the introduction of new housing benefit schemes in New Zealand and Iceland may have had some impact on housing costs. From 1996/97, however, a major restructuring of social welfare in Canada will take place, which is likely to result in substantially less federal support for provincial assistance schemes (see Volume Two, Chapter Five). Already some provinces have reduced benefit levels.

\subsection{Conclusion}

This chapter has sought to compare the level and structure of social assistance in the OECD countries usin ${ }^{\mathrm{g}}$ techniques of policy simulation and model families. These methods have their limitations and the conclusions have to he regarded with some caution. Nevertheless. the analysis has shown that the income levels of families dependent on social assistance in 1992 varied considerably between countries. They also varied between and within countries, by family type and according to whether the comparisons are made before or after housing costs. However. the highest levels of benefit overall appeared to be awarded in Switzerland (more specifically in Fribourg, since payments vary throughout the country), Luxembourg, the Netherlands. the Nordic countries and Australia. As we have seen in the previous chapters. among this group the Nordic countries and Switzerland have common characteristics - they have relatively high levels of GDP. traditionally low levels of unemployment, and social assistance schemes which are residual and locally administered. They also all have strict means tests --- Swiss assistance arrangements can be seen as basically a loan to the extended family -while in the Nordic countries there are few capital or earnings disregards and an emphasis on encouraging claimants to return to the labour market. These common 
features lead one to speculate that countries can have higher levels of social assistance provision when they are of benefit to only a small number of claimants, when they have a strict means test and the capacity to organise behavioural interventions. However, this hypothesis does not explain the position of Australia and the Netherlands in the leading group. The significance of the differences in payment levels identified here is explored further in Chapter Eight.

Table A6.1: Gross average male earnin ${ }^{\mathrm{g}}$ s per month, May 1992

\begin{tabular}{|c|c|c|c|}
\hline & National currencies & $£$ sterling, PPPs & S US, PPPs \\
\hline Australia & 2,575 & 1.209 & 1.922 \\
\hline Austria & 23,772 & 1.046 & 1.662 \\
\hline Belgium & 73,845 & 1.203 & 1,912 \\
\hline Canada & 2.892 & 1,446 & 2.299 \\
\hline Denmark & 19.333 & 1.302 & 2.070 \\
\hline Finland & 10.292 & 997 & 1,585 \\
\hline France & 9,600 & 922 & 1.577 \\
\hline Germany & 4,417 & 1,319 & 2.097 \\
\hline Greece & 186,400 & 674 & 1.072 \\
\hline Ireland & 1,219 & 1.184 & 1,882 \\
\hline Italy & $2,583.000$ & 1,091 & 1.734 \\
\hline Japan & 369.290 & 1,223 & 1,944 \\
\hline Luxembourg & 78.863 & 1,249 & $1 ; 989$ \\
\hline Netherlands & 3,989 & 1.153 & 1,883 \\
\hline New Zealand & 2,757 & 1,112 & 1.768 \\
\hline Norway & 17,333 & 1.182 & 1.879 \\
\hline Portugal & 81.700 & 438 & 696 \\
\hline Spain & 177,092 & 952 & 1,513 \\
\hline Sweden & 14,248 & 896 & 1,425 \\
\hline Switzerland & 4.643 & 1,323 & $2: 103$ \\
\hline United Kingdom & 1,208 & 1.208 & 1,920 \\
\hline USA NY & 2,245 & 1,412 & 2,245 \\
\hline
\end{tabular}

Note: Earnin ${ }^{\mathrm{g}} \mathrm{s}$ data were not available for bland.

Source: Authors' estimates, based on the 1989 Tax-Benefit Position of Production Workers (OECD. 1990). updated using index of hourly earnings of production workers (OECD. Main Economic Indicators). 
Table A6.2: $\quad$ Purchasing power parities and exchange rates (UK - 1.00), May 1992

\begin{tabular}{|c|c|c|c|c|}
\hline & \multicolumn{2}{|c|}{ Purchasing power parity 1992} & \multicolumn{2}{|c|}{ Exchange rates: average daily rate 1992} \\
\hline & & $\mathbf{L} \mathbf{S S}$ & & USS \\
\hline Australia & 2.13 & 1.34 & 2.39 & 1.36 \\
\hline Austria & 22.73 & 14.30 & 19.28 & 10.98 \\
\hline Belgium & 6137 & 38.60 & 56.40 & 32.14 \\
\hline Canada & 2.00 & 126 & 2.12 & 1.20 \\
\hline Denmark & 14.85 & 9.34 & 10.60 & 6.04 \\
\hline Finland & 10.32 & 6.49 & 7.87 & 4.48 \\
\hline France & 10.41 & 6.55 & 9.29 & 5.29 \\
\hline Germany & 3.35 & 2.11 & 2.74 & 1.56 \\
\hline Greece & 276.63 & 174.00 & 334.21 & 190.49 \\
\hline Iceland & 136.25 & 85.70 & 101.09 & 57,62 \\
\hline Ireland & 1.03 & 0.651 & I.03 & 0.58 \\
\hline Italy & $2.367 .{ }^{2} 5$ & 1.489 .00 & 2161.40 & 1.231 .99 \\
\hline Japan & 302.00 & 190.00 & 222.28 & 126.69 \\
\hline Luxembourg & 63.12 & 39.70 & 56.40 & 32.34 \\
\hline Netherlands & 3.46 & 2.18 & 3.08 & 1.75 \\
\hline New Zealand & 2.48 & 1.56 & 3.26 & 1.85 \\
\hline Norway & 14.66 & 9.22 & 10.90 & 6.21 \\
\hline Portugal & 186.60 & 118.00 & 236.49 & 134.79 \\
\hline Spain & 186.00 & 117.00 & 179.65 & 102.40 \\
\hline Sweden & 15.90 & 10.00 & 10.22 & 5.82 \\
\hline Switzerland & 3.51 & 2.21 & 2.47 & 1.40 \\
\hline Turkey & $5,608,90$ & 3.528 .00 & $12,036.84$ & 6.860 .52 \\
\hline UK & 1.00 & 0.629 & 1.00 & 0.57 \\
\hline USA & 1.59 & 1.00 & 1.75 & 1.00 \\
\hline
\end{tabular}

Source: OECD: Economic Outlook SU. December 1993, Table A33

Table A6.3: Social assistance (before housing costs) as percentage of average gr ss earnings, 1992

\begin{tabular}{|c|c|c|}
\hline & Couple 68 & Couple + two children $(7,14)$ \\
\hline Australia & 43 & 56 \\
\hline Austria & 28 & 47 \\
\hline Belgium & 34 & 46 \\
\hline Canada & 55 & 47 \\
\hline Denmark & 49 & 51 \\
\hline Finland & 45 & 58 \\
\hline France & 53 & 41 \\
\hline Germany & 23 & 36 \\
\hline Greece & 11 & 6 \\
\hline Ireland & 34 & 41 \\
\hline Italy' & 38 & 49 \\
\hline Japan & 30 & 54 \\
\hline Luxembour $^{\mathrm{g}}$ & 44 & 61 \\
\hline Netherlands & 44 & 52 \\
\hline New Zealand & 44 & 45 \\
\hline Norway & 45 & 71 \\
\hline Portugal & 36 & 42 \\
\hline Spain & 23 & 31 \\
\hline Sweden & 47 & 83 \\
\hline Switzerland & 61 & 81 \\
\hline United Kingdom & 32 & 43 \\
\hline USA NY & 36 & 45 \\
\hline USA Pen & 34 & 29 \\
\hline USA Texas & 33 & 25 \\
\hline USA Florida & 33 & 32 \\
\hline
\end{tabular}

Assistance data for non-pensioners in Italy needs to he treated with some caution. 


\section{Chapter 7 Social Assistance, Work and Incentives}

\subsection{Introduction}

This chapter is concerned with the relationship between receipt of social assistance and participation in the paid labour force. The analysis is primarily descriptive. This is because information on the actual effects of benefit systems on labour force behaviour varies greatly in availability and detail. with much more information being available for a small range of countries, including the USA and the UK. This chapter therefore seeks to provide an overview of arrangements in OECD countries that may influence labour supply behaviour, including the extent to which social assistance recipients may also receive income from earnings, as well as the extent to which exit from or entry to the labour force is facilitated or impeded.

Before turning to a description of relevant aspects of social assistance arrangements, it should be noted that the scope of this chapter has deliberately been limited. Many aspects of benefit rules may potentially affect workforce participation. For example. in all of the countries in this study the means test for social assistance is based on joint family income, or may be wider and include all sources of household income, or even potentially take account of the resources of other relatives (in Germany. Italy, Japan and Switzerland for example). Under a joint means test. the labour force behaviour of both partners may be affected by the substitution effects of the benefit withdrawal rate -- the 'perverse additional worker effect' (Scherer, 1978: Bradbury, 1993). In contrast. under a social insurance system. incentive effects will be largely confined to the recipient. ' Thus, the foreshadowed reforms to the Australian unemployment assistance scheme include Iiberalisation of the family means test, in order to improve workforce incentives for second earners in couples.

Moreover. in many social assistance schemes. including those of Denmark. Finland. Germany, Sweden and the United Kingdom, universal child benefits are deducted from social assistance rates. In the United Kingdom. it has been argued that this provides a financial incentive to increase income. and may therefore encourage earlier return to the labour force. In addition, cohabitation rules may not only affect choices about household formation, but also longer-term decisions about work. The age at which children cease to qualify as dependent may have a powerful impact on lone parents' incentives to enter the workforce. The way benefits are administered and the ease by which claimants are transferred from outof-work benefits to in-work benefits may influence the willingness of recipients to move into work.

Indeed. it could be argued that any measure that makes social assistance either more restrictive or more widely available will have potential effects on labour force participation. But it would clearly be impractical to attempt to draw out all of the implications of the details of benefit administration for labour force participation, and it would also replicate much of the information contained in other chapters. Therefore, this chapter follows a number of themes in order to illuminate the possible range of approaches to encouraging workforce participation.

We concentrate on people of workforce age, mainly the unemployed and lone parents. After discussing some background data from a variety of OECD sources,

\footnotetext{
' Assuming that the income effect associated with the provision of' benefits lower than insured earnings will encourage increased participation.
} 
we consider the duration conditions for social assistance, as well as the length of time for which unemployment assistance is available. More limited information is available on actual duration of receipt of social assistance. This is then followed by a discussion of work tests and sanctions (sticks'), as well as information on active insertion' or 'integration ' programmes for social assistance beneficiaries, and other 'carrots' to encourage active labour market involvement. It should be noted, however, that we have not collected information on labour market programmes more generally. so this description is limited. Finally, the chapter describes the structure of the means tests applying in different OECD countries, and presents calculations of benefit replacement rates and effective marginal tax rates.

\subsection{Background data}

In setting the context for the discussion that follows, Table 7.1 provides selected details of labour force statistics for OECD countries in 1992. The unemployment rate in these countries ranged between 1.5 per cent in Luxembourg (registered unemployed) ${ }^{\text {io }}$ and just over 18 per cent in Spain. with the OECD average being 7.4 per cent. It should he noted, however. that different countries were at different stages in the economic cycle in 1992, so that unemployment has since fallen in the United States, Canada. the United Kin ${ }^{\mathrm{g}}$ dom. Australia and New Zealand, but has risen in many other countries. particularly Finland, Sweden and Spain, and to a lesser but still significant extent in Belgium. France, Germany and the Netherlands.

The table also provides estimates of the extent of long-term unemployment, here defined as 12 months or over. It is likely that the extent of long-term unemployment is one important influence on claims for social assistance. although eligibility for unemployment insurance extends past one year in many countries, It should also be noted that the extent of long-term unemployment will tend to fall in the early stages of recessions. as many new unemployed people enter the unemployment stock. It could also be expected that the proportion who are longterm unemployed will increase in the early stages of' economic recovery.

The table also shows estimates of the long-term unemployed as a percentage of the total labour force. The proportion was very low .... under half of one per cent - in Japan. Luxembourg and Sweden, and was under one per cent in Austria and the United States. Long-term unemployment was between three and live per cent of the labour force in Australia, Bel ${ }^{g}$ ium. Denmark. France. the Netherlands. New Zealand, and the United Kingdom. Long-term unemployment was very high in Ireland and Spain. at around nine per cent. and also high in Italy, at around six per cent.

However, participation rates vary substantially across countries, and it is possible that in those countries with lower participation rates there are more discouraged workers and more eligible for social assistance. Participation rates were lowest for men in Belgium. France, Greece and Spain, and highest in Switzerland, Japan, Denmark, Australia, the USA. the UK and Sweden. The extent of part-time employment also varied substantiallyi with it tending to be high for men in those countries with higher participation rates, although the Netherlands stands out with the highest part-time rate for both men and women. Again, part-time employment for women tends to be highest in those countries with the highest part-time employment for men, with the exception of the United States.

Finally, labour force growth rates differ substantially across OECD countries, being highest in the 1983-91 period in Luxembourg, the Netherlands, and Australia - at three or more times the OECD average. They have been very low in Finland, Belgium, Ireland, Greece, and Sweden. 1992 was a year of low employment growth for the OECD, with substantial falls in the Iabour force in Iceland, Finland and Sweden. and more modest falls in Portugal, Switzerland and the United Kingdom.

The bracketed figures are based on registrations, and the other figures are standardised and drawn from labour force surveys. The OECD average refers to the standard figures only. 
Table 7.1: Selected labour force statistics for OECD countries. 1992

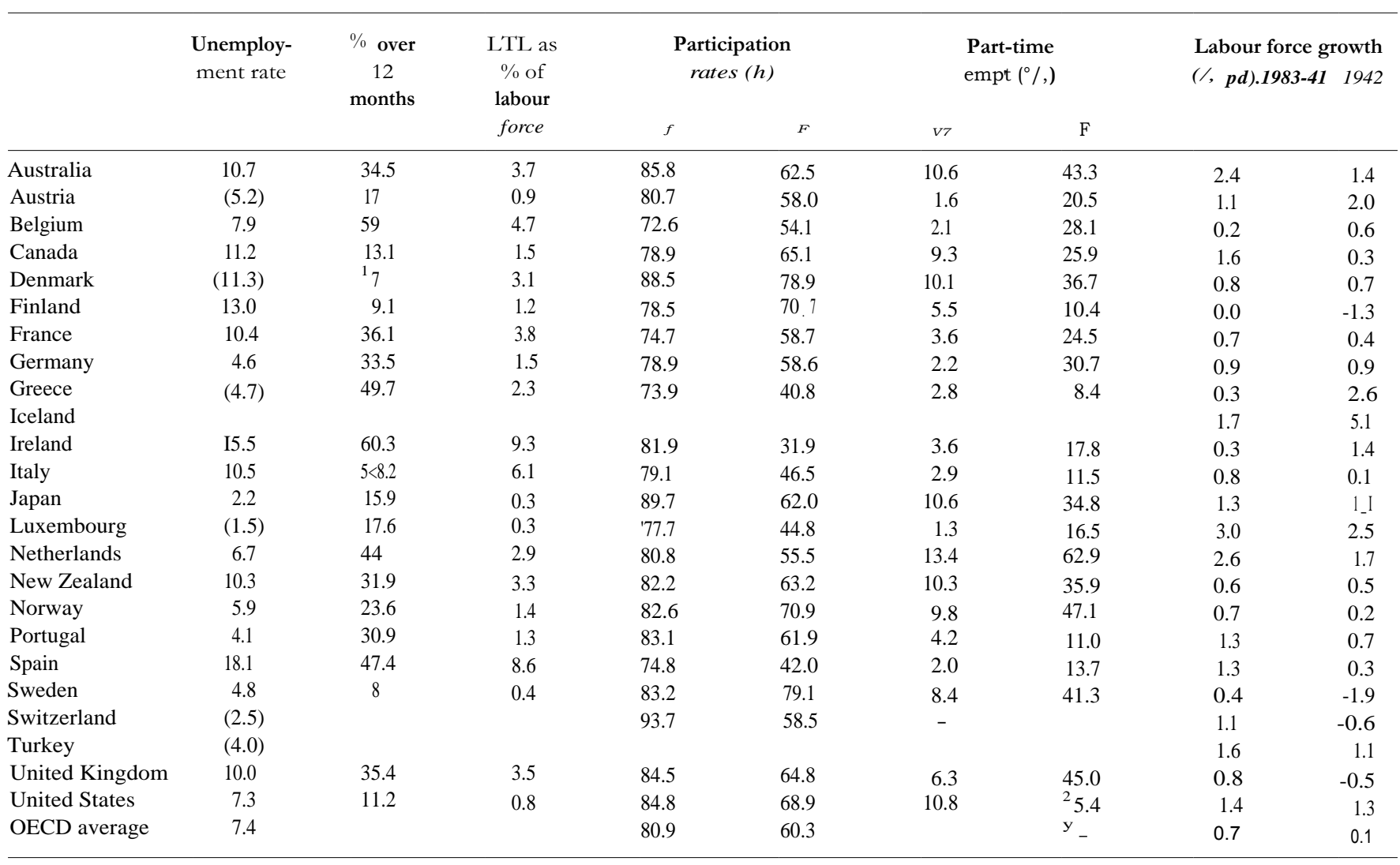

Source: OECD. Employment Outlook; July 1994, and Hain Economic Cnslicators, various years.

A major determinant of the extent of concern with work incentive issues will be the number of people receiving social assistance, particularly the number of people of work force age who could reasonably be expected to participate in the labour market. or 'emp.ioyables' in the Canadian parlance. Chapter Two provided information on the overall extent of receipt of social assistance, plus some data on the level of receipt among different categories of recipients.

In general. as we saw in Chapter Two, the proportion of the population in receipt of income-related benefits in 1992 was highest in New Zealand and Australia, where between one-fifth and one-quarter of the population received such assistance. The next highest proportion in receipt of social assistance was in the United Kingdom. where one person in six in the population was covered by Income Support. For some of these people. Income Support is a supplement to social insurance benefits. In the case of Canada, around ten per cent of the total population were estimated to be receiving social assistance. The proportion of the population in receipt of social assistance appeared to be relatively high in Finland, Ireland and the United States, although it was also significant in Sweden and Germany.

However, more important for the purposes of this chapter than the salience of social assistance generally is its importance for those people who would normally be expected to be active in the labour market, in particular those people of working age. Unfortunately the data on this are not available for all countries. We have already seen that the level of unemployment and long-term unemployment varies considerably between countries. In addition to these factors there is certainly variation in the coverage and level of social insurance benefits for the unemployed which will have an impact on the proportion of unemployed people receiving social assistance. Table 2.8 presented data for some countries on the proportion of the total population who were lone parent or unemployed social assistance recipients. From this it is possible to conclude that among the countries for which we have data this varied from relatively few in Luxembourg and Portugal to about a third in the $U K$. half in Canada and Ireland, two thirds in the Netherlands and nearly 
all in Sweden. It is also highly likely that the types of unemployed recipients of social assistance varies in different countries. Thus for example about two-thirds of social assistance recipients in the Nordic countries are young single persons who have not established an entitlement to insurance benefits. By contrast, in the UK, couples with children are the largest group of unemployed recipients of social assistance.

\subsection{Duration of assistance}

Table 7.2 summarises the information collected on duration conditions for receipt of unemployment insurance and for social assistance. Duration of unemployment insurance varies widely, and it will also vary within countries depending on the age of the individual and his or her employment history. It will be recalled from Table 7.1 that the extent of long-term unemployment was greatest in Ireland. Spain and Italy, followed at some distance by Belgium, France, Australia, the United Kingdom, New Zealand. Denmark and the Netherlands. Duration of unemployment insurance appears to be longest in the Netherlands and Belgium, assuming that individuals have had some recent employment. Duration in Spain is quite extended. but less so in Ireland. and appears to be limited in Italy.

While Australia and New Zealand do not provide unemployment insurance, it could be argued that in an informal sense - and until recently - they have provided the most generous conditions of unemployment coverage, since benefits were effectively available on an unlimited basis without contribution histories. The system of Income Support in the UK. also provides similar unlimited benefits, should an unemployed person move from Unemployment Benefit to Income Support after 12 months.

In most of these countries_the duration of social assistance is unlimited while individuals continue to remain eligible. The exceptions relate to young people in Portugal and New Zealand. More importantly, administrative discretion, plus the assumption that social assistance is for limited periods. appear to apply in Austria, Denmark, Italy, Spain (outside Madrid). Switzerland and Turkey. It can also be noted that in the USA, AFDC is directed towards those with children, while the more residual General Assistance varies across jurisdictions. It is also readily apparent that the most complex set of programmes apply in France, where there is a wide range of benefits for particular contingencies.

In summary. it is not possible with this data to relate systematically the duration rules to long-term unemployment rates. Such a relationship has been found in other studies (for example, OECD, 1994a). From observation. there does appear to be some broad measure of correlation between countries with more relaxed duration conditions and lon ${ }^{\mathrm{g}}$ er-term unemployment. However, those countries with the longest duration of unemployment do not have the most generous duration rules, suggesting that the general state of the labour market in these countries will have an important impact. 


\section{Duration of unemployment insurance}

Australia $\quad$ No insurance. All assistance is available for as long as the claimant qualifies, except for Job Search Allowance and Sickness Allowance.

$\overline{\text { Austria } \quad \text { Move to Unemployment Assistance after 5- } 12 \text { months }}$

Belgium Unemployment Benefit for 18 months, up January 1994. Then 15 months, plus 3 months per year of employment. Unlimited for those

who worked 20 years or more, or one-third incapacitated. Others can be suspended if unemployment more than twice regional average

for their type.

Canada Maximum of 50 weeks. varying by preceding eligible employment and

local unemployment rate. Range changed from 46 -50 weeks to 35"50 weeks in 1990.
Duration of social assistance

People claiming JSA over the age of 18 are eligible for the first 12 months only, thereafter they may claim the New Start Allowance.

Sickness Allowance for 12 months, renewable for further 12 months in special circumstances, and in certain circumstances 24 months. This is reviewed every 13 weeks. Other benefits unlimited while eligible.

There is no fixed time limit on claiming. At the discretion of provincial authorities it earn he given for a limited or unlimited time. It can be unlimited for older people, those with disabilities, or young children. Permanent recipients receive higher 7ea;efii lone mothers among them. Other recipients may als receive higher benefits if there is greater need, its their circumstances may suggest.

All minimum benefits are unlimited while eligible as long as all the conditions are met and resources are still low. C'ockx (1992) found a high turnover: 93\% of males and of women sign off of-tea three years. Many who cone off the

Minimex remain in lower-income bands.

There is no limit, provided that each household still satisfies the conditions. Some provinces require monthly re-applications, such as unemployed adults who have to reapply every month. This is used as a monitoring system and also who have to reapply every month. This is used as a mon
an encouragement to reintegrate into the labour :market.

Essentially social assistance is only short term. Local municipalities reconsider cases at 3 month intervals to see if other forms of assistance might be more appropriate. There is an expectation of short term duration.

There are no limits as long as the conditions remain met social assistance.

\begin{tabular}{ll} 
Finland & $\begin{array}{l}2 \text { years. Indefinite flat-rate benefit thereafter. but lower than } \\
\text { social assistance. }\end{array}$ \\
\hline France & Maximum of 60 months
\end{tabular}

$\begin{array}{ll}\text { Germany } & \text {.lrbeitslosengeld for between } 17 \text { and } 52 \text { weeks'. up to } 104 \text { weeks } \\ \text { for older work.ers. Arlbeitslosenhilje unlimited in principle. }\end{array}$

Greece The duration of unemployment insurance varies according to the period of previous paid employment. Maximum duration of benefits is 12 months for 250 days of previous employment.

Iceland All members of a trade union and all self-employed people (since 1993) are entitled to 180 days during a 12 month period. Entitlement is based on having worked 425 hours in the previous 12 months. The rate varies according to the number of hours.

reland Maximum of 15 months claimin $^{\mathrm{g}}$, and the claimant must have paid contributions for over 39 weeks in the tax yea
AA.II for 5 years renewable. API for 12 month: or once younge ${ }^{\mathrm{s}} \mathrm{t}$ hild $\mathrm{r}$.rns 3 .

$\mathrm{Ml}$ unlimited. AV for 3 years. or 5 if over 50 at partner's death. ASS renewable every 6 months. but unlimited in principc. Al up to 12 months. RMVII `or 3 months, then 3 "f2 months following insertion contract.

As long as the condi!ii ns are met there is no tutu

Unlimited, except First-time Jobseekers

Allow; ,, which lasts only a maximum of five months

There are no limits to the duration of entitlement to linaaacaa] assistance

Assistance available indefinitely as long as all conditions are still met 
Duration of unemployment insurance

Italy f redundant, up to 270 days. Other unemployed up to 6 months.

\begin{tabular}{ll}
\hline Japan & Basic allowance of $60-80 \%$ of the previous wage for $90--300$ days \\
\hline Luxembourg & 365 clays in a 24 month period. Further 612 months for those aged over 50. \\
\cline { 2 - 2 } Netherlands & $\begin{array}{l}\text { 26 weeks if covered for }{ }^{26} \text { out of previous } 52 \text { weeks. } \\
\text { Then up to } 4.5 \text { years if employed for } 3 \text { out of } 5 \text { previous years. } \\
\text { Then } 1 \text { extra year or } 3.5 \text { years if aged } 57.5 \text { years or over. }\end{array}$ \\
New Zealand & Not applicable \\
$\begin{array}{l}\text { Norway } \\
\text { ast }\end{array}$ & Unemployment Benefit is available dependent on wages \\
$\begin{array}{l}\text { Portugal } \\
\text { Contributory unemployment benefit is payable for between ten and } 30 \text { months, }\end{array}$
\end{tabular}

Spain $\quad$ Maximum of 24 months

Sweden 300 days maximum, and tap to 450 days for those $55--65$ years

Switzerland Maximum of 250 days if contribution paid for at least 18 months

Turkey There is a 'term a.tion benefit' available for a short time on redundancy

United Kingdom UB is currently payable for 12 months. After this it is possible to requalify if working for 13 weeks in following 6 months. JSA for 6 months from 1996.

United States $\quad$ Up to 26 weeks, extended in some states, and depending on unemployment rate. to up to 1 year. 1992 average of 16 weeks.

\section{Duration of social assistance}

Duration is unlimited in cases of nationals. but limited with the possibility of renewal in local cases. M.inimo Vitale can be paid without limits for pensioners and those with disabiliti.:>, it is always temporary ( 3 months) for others. As long as conditib is are -.till met it is unlimited while eligible

As long as conditions are still met it is unlimited while eligible

As long as conditions are still met it is unlimited while eligible

There arc no time limits on claiming, with one exception. The JSA for $16 \cdot 17$ year olds is Limited to 3 months, after which it is expected that claimants will complete a training scheme or some education.

Available without limit, as $\operatorname{lon}^{\mathrm{g}}$ as conditions are met and need continues

The duration of entitlement varies by benefit as follows:

For Young People's integration Benefit the duration is 15 months.

Orphan's Pension- up to the age of 18

Orphan's Pension- up to the age of 18 .
Family Allowance- for children up to the age of 25 if in education.

Supplementary Allowance for handicapped and young people, up to 18.

Duration varies between 6 and 12 months, though it can he longer in certain

circumstances. It varies by region:

6 months- Valencia, Andalucia, Madrid.

12 months- Aragon. Basque, Cantillia, Catolonia, Galicia, Murcia and Navarra.

It is always available as long as the conditions are met

There are no set limits, but the normal expectation is that it is temporary, except for older people and those with disability

OAA benefits are lifelong, or iii the case of a disability as long as siu;r ne is unable to work. Duration of SA benefits is dependent on the fuund ions that administer it.

As long as the conditions are still met there is no limit

No limits for SSI, AFDC or FS. As regards GA in New York, benefits are available indefinitely as long as conditions are met.. The same is true in Harris County. Texas. In Pennsylvania benefits for the needy are available indefinitely, but for the "transitionally needy" they are restricted for 3 months in every 12. All GA benefits in Dade County, Florida last for six months. 
Table 7.3 presents a range of information on the duration of receipt of social assistance benefits which was provided by the national informants for this study. Particular care should be taken with these comparisons, as it is highly likely that duration has been measured in different ways in different studies, some being average current duration of receipt. some covering average completed duration, and with information coming variously from cross-section and from panel data. In some cases, the information is based on spells of benefit receipt, while in others it only applies to particular parts of the country.

it should also be remembered that recipients of social assistance will only be a subset of the long-term unemployed, and that many recipients will actually be outside the labour market. Nevertheless, with the exception of Finland and Sweden, it appears that receipt of social assistance appears to be a long-term state for at least a significant minority of recipients. It should also be noted that many of these results refer to lone parents, and research tends to $\mathrm{su}^{\mathrm{g}}$ gest that the main reason for lone parents ceasing to receive benefits is either the formation of a new relationship or the ending of responsibility for a dependent child, rather than (re)entry to the labour force.

Bearing in mind the problems of comparability, it still appears that the proportion of lone parents receiving benefits for a year or more is rather similar in Australia and the UK, while the average current duration of receipt by lone parents is similar in Australia and in Canada. Average receipt of Domestic Purposes Benefit in New Zealand is less than three years, although it should be remembered that current duration will be shorter when the number of new recipients is growing rapidly. However, it is particularly notable that receipt of AFDC by single mothers in the USA appears to be very long. with 70 per cent of recipients being on benefits for two or more years. ${ }^{\mathrm{t} l}$

Receipt of benefits by single. unmarried mothers is longer than by separated mothers in the UK and Australia, and it is not clear from the source whether the US study by Ellwood covered only unmarried mothers.. or included other lone mothers. 
Table 7.3: Measured duration of receipt of social assistance benefits for selected count ${ }^{\mathrm{I}}$ ies

\begin{tabular}{|c|c|c|}
\hline & Duration & Source \\
\hline Australia & $\begin{array}{l}\text { ISA and NSA: Mean }=66 \text { weeks, Median }=35 \\
\text { weeks. } 70 \% \text { of sole parent pensioners receive } \\
\text { pension for } 12 \text { months or more. Average current } \\
\text { duration for female SPPs of } 3.4 \text { years. }\end{array}$ & $\begin{array}{l}\text { Australian DSS } \\
\text { statistics, } \\
\text { May } 1993\end{array}$ \\
\hline Austria & $60 \%=$ 'lon $^{\mathrm{g}}$-term recipients' & Steiner, 1994 \\
\hline Belgium & Minunex: around I year (men); IS months (women) & Cocks. 1992 \\
\hline Canada & 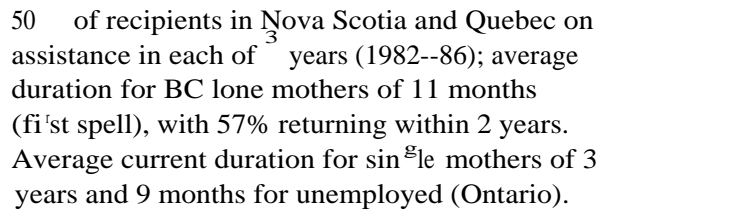 & See Evans, 1994 \\
\hline Finland & $\begin{array}{l}=3 \text { months }-\quad 4-6 \text { months }-20 \% \\
7--9 \text { months }-\mathrm{I} 1 ">10 \text { months }-\mathrm{I} \mathrm{I} \%\end{array}$ & Volume 2, p. 238 \\
\hline Germany & $\begin{array}{l}\text { Median duratio: of receipt }=23 \text { months (out of } 72 \text { ). } \\
\text { Median duration of episodes - } 12-18 \text { months. }\end{array}$ & $\begin{array}{l}\text { 'loges and Robwer, } \\
\text { 1992. p. I84-185 }\end{array}$ \\
\hline Netherlands & $\begin{array}{l}38 ' 3 \text { of } A B W \text { and } 29 \text { ta: of RWW recipients claiming } \\
\text { for } 5 \text { or more years }\end{array}$ & Volume 2, p. 500 \\
\hline New Zealand & $\begin{array}{l}\text { Average duration of DPB }=2 \text { years, S months. } \\
1988-2^{2} \% \text { of unemployed for more than } 27 \text { weeks. } \\
1992--44^{\circ}, z \\
1993 . .807 ;\end{array}$ & $\begin{array}{l}\text { Stephens, } 1994 . \\
\text { 'NZ Department of } \\
\text { Social Welfare }\end{array}$ \\
\hline Swede & $\begin{array}{l}\text { in } 1993.29 \% \text { of households received benefit for less than I } \\
\text { month. } 28 \% \text { for } 2-3 \text { months. } 637 \text { for whole of year. } \\
\text { Average duration in } 1994 \text { was } 5 \text { mouths. }\end{array}$ & $\begin{array}{l}\text { Sociaalstyrelsen, } \\
1994\end{array}$ \\
\hline Switzerland & $\begin{array}{l}\text { Avera }{ }^{\mathrm{g}} \text { e duration }=1.9 \text { years for divorced and } \\
\text { separated; } 1.3 \text { years for unemployed (Tessin] }\end{array}$ & Guillaume- 1994 \\
\hline United Kingdom & $\begin{array}{l}6573 \text { claiming for at least I year, and } 44 \% \text { for } 2 \\
\text { or more years. Just over half of long term aged } \\
\text { over } € 0.70 \% \text { of lone parents on benefit for } \\
\text { over } 1 \text { year. }\end{array}$ & DSS statistics, 1993 \\
\hline t sited States & $\begin{array}{l}\text { Mid-1980s: } 30^{\circ} \% \text {. of single mothers on AFDC for } \\
\text { under } 2 \text { years- } 40^{`} 1 \text { for } 3-7 \text { years, } 30 \% \text { for } S \text { or } \\
\text { more years }\end{array}$ & Ellwood, 1988 \\
\hline
\end{tabular}

\subsection{Job search requirements}

Table 7.4 provides an overall summary of the job search requirements for the main assistance benefits in the countries in our study. In the great majority of countries, there is a work test in operation which usually requires that recipients register as unemployed and establish that they are actively looking for work. The exceptions to this include Greece, where the only general payments are made on a one-off basis, and a work test for recurrent eligibility is not relevant. In addition, in Japan, outside Reykjavik in Iceland, and in Switzerland it appears that the requirement to seek work is not a formal rule. but that there are very strong expectations that individuals will make full use of their capacities. Work tests can also be applied informally through the basic conditions of eligibility. For example, the discourse on social assistance in Canada appears to make a strong distinction between the 'employable' and the 'unemployable', while in several of the United States. General Assistance is simply not available to able-bodied single people or couples without children - surely the strongest possible expression of the requirement to be actively seeking work. At the other extreme, under ten per cent of the already small number of social assistance recipients of Luxembourg are affected by the work test.

In virtually all countries, work tests are not applied. or are more relaxed. for people who are ill or experience disabilities. or who are over or approaching retirement age. The major variations relate to lone parents, in particular to the age of children who exempt lone parents from the requirement to actively seek work. The most liberal provisions apply in Ireland. the United Kingdom, Australia and 
New Zealand. where lone parents are not required to seek work until their youngest child is 16 years (or older). Requirements vary across provinces of Canada, from the most restrictive (six months) to the more generous (12 years). Germany is also relatively liberal in this respect, as lone parents must normally seek part-time work when their youngest child is at school. and full-time work when the child is 14 or over. In Norway, lone parents receiving the Transitional Allowance are not required to seek work until the youngest child turns ten years of age. In Luxembourg and the Netherlands, the qualifying ages are six years and five years respectively. In Austria and Finland, the qualifying age is three years. while in Sweden the age is being liberalised from about 1.5 months to three years. In both Sweden and Denmark, however - the two countries with the strongest expectation of work or work-seeking ---- municipalities are required to provide child care for lone parents looking for work. In France, the extent to which lone parents receiving the RM1 would be expected to engage in 'insertion' activities varies both by dcpertements and according to individual circumstances. Those with children under three receiving the Allocation de Parent Isole are not required to seek work. 


\begin{tabular}{|c|c|c|c|c|}
\hline & Work test & Sanctions/I ncentirea & Job offers/training schemes & Hours rules \\
\hline Australia & $\begin{array}{l}\text { Unemployed people must demonstrate that } \\
\text { they have sought work in the last two } \\
\text { weeks, (the "actively seeking work test") } \\
\text { The requirements differ by category of } \\
\text { people. namely oleic) people. lone parents, } \\
\text { short or long-term unemployed people } \\
\text { The activity test is not applicable to those } \\
\text { aged } 60 \text { and pension age Those near } \\
\text { retirement age do not have to look for work. } \\
\text { fo qualify for fortnightly payments people } \\
\text { must advise the Commonwealth } \\
\text { Employment Service of their efforts to find } \\
\text { work. }\end{array}$ & $\begin{array}{l}\text { The lcr.ment of income support } \\
\text { is linked to satisfying the work } \\
\text { test. Failure to do so may mean } \\
\text { loss of benefit. }\end{array}$ & $\begin{array}{l}\text { Refusing a a job } h \text { offer or trainin } \\
\text { scheme may he seen as failing } \\
\text { the qualification test }\end{array}$ & $\begin{array}{l}\text { Unemployed people can do up } \\
\text { to } 20 \text { hours voluntary work a } \\
\text { week but there are limits, so tlatit } \\
\text { they spend some of their time } \\
\text { looking for paid work. This } \\
\text { varies by client. For example. } \\
\text { those under } 18 \text { can do up to } 30 \\
\text { days a year. but those aged } 18 \text { - } \\
49 \text { can only do this much if } \\
\text { unemployed for more than } 6 \\
\text { months. }\end{array}$ \\
\hline Austria & $\begin{array}{l}\text { Yes, but not applicable to lone parents, } \\
\text { with child =3; disabled; } 60 \text { years and over. } \\
\text { Others register with Labour Markel } \\
\text { Administration, }\end{array}$ & Partial or full loss of benefit & $\begin{array}{l}\text { Not compulsory. No specific } \\
\text { insertion or integration } \\
\text { agreements. }\end{array}$ & $\begin{array}{l}\text { No limit, but laconic test } \\
\text { implies part-time work }\end{array}$ \\
\hline Belgium & Yes, not ill and lone parents (discretion) & $\begin{array}{l}\text { For } 25 \text { partial or total } \\
\text { suspension for } 1 \text { month for } \\
\text { noncompliance with 'integration } \\
\text { contract'. Up to } 3 \text { months for } \\
\text { repeated non-compliance. }\end{array}$ & $\begin{array}{l}\text { 'Programme for More } \\
\text { Solidaristic Society' compulsory } \\
\text { for <25. 'Social employment' by } \\
\text { municipalities }\end{array}$ & $\begin{array}{l}\text { No liniit, so long as available } \\
\text { for fall-time work }\end{array}$ \\
\hline Cinada & $\begin{array}{l}\text { Distinction between employable and } \\
\text { unemployable across provinces For } \\
\text { employables, must be involuntary and } \\
\text { taking active steps. Tone parents may be } \\
\text { exempted. but age of child for exemption } \\
\text { varies from } 6 \text { months to } 12 \text { years. More } \\
\text { relaxed with older workers. }\end{array}$ & $\begin{array}{l}\text { Suspension, reduction or } \\
\text { termination, varying across } \\
\text { provinces. Quebec most } \\
\text { systematic in sanctions. } \\
\text { Assistance for travel and care } \\
\text { costs in enhancement } \\
\text { programmes. }\end{array}$ & $\begin{array}{l}\text { ismployxhility enhancement } \\
\text { measures not compulsory. } \\
\text { "Four-cornered agreements } \\
\text { f'cac' increased participation by } \\
\text { claimants. General programmes } \\
\text { may have designated places for } \\
\text { recipients. }\end{array}$ & $\begin{array}{l}\text { No hours limit, but } \\
\text { earnings reduce benefits }\end{array}$ \\
\hline Denmark & $\begin{array}{l}\text { Yes eonfirmation friant employment } \\
\text { service that seeking job. If ill, they may be } \\
\text { exempt. With child, exempt if municipality } \\
\text { unable to provide sufficient child care. }\end{array}$ & Loss of benefit possible & $\begin{array}{l}\text { Yowl' Allowance for } 1824 \mathrm{~s} \text {. } \\
\text { Compul.or_y to undertake } \\
\text { training or other approved } \\
\text { scheme. MonieipitI Activation } \\
\text { Act for people up to } 66 \\
\text { Claimants may lose benefits, but } \\
\text { optional for municipalities }\end{array}$ & $\begin{array}{l}\text { No limit, so limp as not in } \\
\text { full-tine job }\end{array}$ \\
\hline Finland & $\begin{array}{l}\text { Able-bodied must register as job seekers. } \\
\text { Varies across municipalities. } \\
\text { No work test for lone parents with }\end{array}$ & $\begin{array}{l}\text { Not clear. } \\
\text { Help available with child care } \\
\text { costs. }\end{array}$ & $\begin{array}{l}\text { No workfare schemes. } \\
\text { Optional schemes, including for } \\
\text { early school leavers. }\end{array}$ & $\begin{array}{l}\text { No limit, but Cara zings reduce } \\
\text { benefits }\end{array}$ \\
\hline
\end{tabular}




\begin{tabular}{|c|c|c|c|c|}
\hline & Work test & Sanctions/Incentives & Job offers/training schemes & Hours rules \\
\hline France & $\begin{array}{l}\text { AI and ASS must register for work. Not } \\
\text { others. API available for } 12 \text { months, or } \\
\text { until youngest child turns } 3 \text {. }\end{array}$ & $\begin{array}{l}\text { Not stated. } \\
\text { Subsidies for employers, inc. } \\
\text { exemption from social security } \\
\text { contributions. }\end{array}$ & $\begin{array}{l}\text { Inse tion contracts for RMI. } \\
30 \% \text { in employment or training, } \\
\text { Some others involve non-labour } \\
\text { market activities. }\end{array}$ & Not stated \\
\hline Germany & $\begin{array}{l}\text { Yes, but not physically or mentally } \\
\text { incapable, if affects children, or hinder } \\
\text { return to previous principal activity. } \\
\text { Older unemployed usually exempt. For lone } \\
\text { parents, normally must seek part-time work } \\
\text { when youngest at school, and full-time at } 14 .\end{array}$ & $\begin{array}{l}\text { Not stated. } \\
\text { Small benefit supplements. }\end{array}$ & $\begin{array}{l}\text { Highly developed general } \\
\text { training. Obligations on } \\
\text { municipalities to offer regular } \\
\text { jobs, or special less regulated } \\
\text { schemes. Compulsory to accept } \\
\text { offers on special employment } \\
\text { schemes but limited spaces. }\end{array}$ & No limits \\
\hline Greece & $\begin{array}{l}\text { First time job seekers must register in special } \\
\text { lists for young unemployed }\end{array}$ & Not stated & $\begin{array}{l}\text { First time job-seekers must accept work } \\
\text { offered by local or central government } \\
\text { agencies or follow vocational training } \\
\text { provided by OAEI) }\end{array}$ & Not stated \\
\hline Iceland & $\begin{array}{l}\text { Since most people who claim assistance } \\
\text { need the benefits to supplement their } \\
\text { income, people call work any hours, but } \\
\text { earnings are taken into account. In } \\
\text { Reykjavik they must provide proof that they } \\
\text { are actively seeking work. }\end{array}$ & $\begin{array}{l}\text { Benefit payments rusty be } \\
\text { reduced if' claimants do not } \\
\text { satisfy the work test }\end{array}$ & $\begin{array}{l}\text { Refusal to accept a job would } \\
\text { lead to the withdrawal of } \\
\text { benefit }\end{array}$ & $\begin{array}{l}\text { Unemployed people can now } \\
\text { enter voluntary work and not } \\
\text { lose benefit }\end{array}$ \\
\hline Ireland & $\begin{array}{l}\text { Compulsory for Unemployment Assistance. } \\
\text { Those claiming Supplementary Welfare } \\
\text { Allowance may be required to seek work if } \\
\text { waiting for decision on claim for fJA_ } \\
\text { Must register with training and employment } \\
\text { authority (FAS). All other exempt }\end{array}$ & $\begin{array}{l}\text { Failure to attend training course } \\
\text { can lead to loss of entitlement } \\
\text { for up to } 9 \text { weeks. } \\
\text { Back to work allowance gives } \\
\text { partial benefits while working. }\end{array}$ & $\begin{array}{l}\text { Apart from compulsory FAS } \\
\text { courses, also voluntary partial } \\
\text { job incentive schemes etc to } \\
\text { provide "second chance" } \\
\text { education and training }\end{array}$ & $\begin{array}{l}\text { CIA allows up to } 3 \text { days work, } \\
\text { but retire rakes Ineligible. } \\
\text { Pre-retirees have earnings limit. } \\
\text { Carers cannot be in full-time } \\
\text { work. SWA not working more } \\
\text { than } 30 \text { hours per week_ }\end{array}$ \\
\hline Italy & $\begin{array}{l}\text { Partially disabled must attend employment } \\
\text { agency and accept suitable job. MV for } \\
\text { able-bodied requires job acceptance or } \\
\text { work. on public projects. }\end{array}$ & Not stated & $\begin{array}{l}\text { Public insertion projects, } \\
\text { but very small coverage }\end{array}$ & Not stated \\
\hline Japan & $\begin{array}{l}\text { Recipients must make full use of } \\
\text { personal capacities. Judgements } \\
\text { discretionary by local authorities. }\end{array}$ & Not stated & Not compulsory & No limit \\
\hline Luxembourg & $\begin{array}{l}\text { Yes, but } 91 \% \text { effectively exempt, due } \\
\text { to age, child<fi years, own invalidity, } \\
\text { caring for sick child or i.ll adult }\end{array}$ & $\begin{array}{l}\text { Benefit can be withdrawn for } \\
\text { tip to } 12 \text { months for } 3 \text { temporary' } \\
\text { suspensions due to non- } \\
\text { compliance. Benefit can be } \\
\text { withheld for voluntary job } \\
\text { leavers. Additional payments } \\
\text { over RMG on social } \\
\text { employment. }\end{array}$ & $\begin{array}{l}\text { Insertion agreements for RMU. } \\
\text { Participation in training low, } \\
\text { but community service options } \\
\text { popular. }\end{array}$ & No limit \\
\hline
\end{tabular}




\section{Work test}

\begin{tabular}{ll}
\hline Netherlands & RV V required to sign on. \\
& ABW exempt, but from 1994. lone parents \\
& required to seek work if no child under 5.
\end{tabular}

required to seek work if no child under 5 .

New Zealand

Compulsory for unemployment benefi

and Independent Youth Benefit.

Relaxed for those 55+. Not applicable

to lone parents.

\begin{tabular}{ll}
\hline Norway & $\begin{array}{l}\text { SEA claimants must he available for } \\
\text { work, and accept offers. } \\
\text { Lone parents with child under 10 } \\
\text { eligible for Transitional Allowance without } \\
\text { work test. Those aged over } 67 \text { and all } \\
\text { disabled exempt. }\end{array}$ \\
\hline Portugal & $\begin{array}{l}\text { Only for claimants of Young Persons } \\
\text { Integration Benefit. Must register at } \\
\text { employment centre. }\end{array}$ \\
\hline Spain & $\begin{array}{l}\text { Must be registered at National Institute of } \\
\text { Employment }\end{array}$ \\
\hline Sweden & $\begin{array}{l}\text { Strict requirements, except for those } 65 \\
\text { years and over, and those with documented } \\
\text { impediments to work. Lone parents must } \\
\text { have child care, but obligatory for } \\
\text { municipality to provide for children 18 } \\
\text { months and over. Parents allowance for } \\
\text { year after- birth (plus 90 days), and not } \\
\text { required to seek work, home care } \\
\text { allowance from July 1994 with no work } \\
\text { requirement for those with children up to } 3 \\
\text { years. }\end{array}$ \\
\hline $\begin{array}{l}\text { Apparently not compulsory. Benefits } \\
\text { depend on assessed need. }\end{array}$
\end{tabular}

'Benefits may he reduced to

absolute minimum' if

work refused.

Rehabilitation allowances

for those with permanently

reduced capacity to work.

Not stated

Many potential sanctions under

RWW, from benefit reduction to

suspension.

aking up jobs from local

Sanctions possible, but not

specified

Job offers/training schentes

Moors rules

Municipalities required to create

No unit

job pools'. Youth job

Guarantee Scheme pays

minimum wage after $6 \cdot 12$

months unemployment.

Pilot programmes for lone

parents. Training beneficiaries

must attend training. Small-

scale optional special work

schemes. Contracts being

considered.

'Voluntary' agreements between young people and municipalitie to take on special work. Work and training schemes available

with pay.

Young people r'u $\cdot$ - undertake vocational training or basic education before registration at employment centre

Proposals for those refusing lob offers to be struck off register

Supreme Administrative Court ruling that benefits cannot he denied if work refused.

Small extra assistance for those

in voluntary community service.
Regional 'social contracts`, but details limited

Municipalities may offer public relief work and organise

training. New unit in National

Board of Social Welfare.

Successful active labour marke

programmes.
Social reinte ${ }^{\mathrm{gr}}$ ation and

client rehabilitation are explicit
Unemployment beneficiaries mast be available for full-time

work. Working sickness

beneficiaries unlikely to he medically qualified. No limits otherwise, but must satisfy income test.

No hours limits. so long as available for full-time work

Not stated

No limit, but income dedaacted

No limit. hull-tithe work likely

to disqualify through income.

\begin{tabular}{lll}
\hline Turkey & Not stated \\
& Expected to seek work Disabled apply & No specialist agencies.
\end{tabular}

objectives. Beneficiary status

expected to he temporary.

Provision of equipment for

productive activity possible

No limit if resources

inadequate 
Table 7.4: Job search requirements in social assistance schemes, OECD countries, $1994 \quad$ (ratitil)

\begin{tabular}{|c|c|c|c|c|}
\hline & Work test & SanetionsIIncenlites & Job otters/training schemes & I lours rules \\
\hline United Kingdom & $\begin{array}{l}\text { es, except lone parents witht child under } \\
16 \text {. or } 19 \text { and in full-time education; ill and } \\
\text { disabled: } 91 \text { ) years and over maternity } \\
\text { confinements; certain carers. Others must } \\
\text { sign on, but not partners of claimants. }\end{array}$ & $\begin{array}{l}\text { Failure to seek work can lead to } \\
\text { ineligibility for benefit. but } \\
\text { hardship payment } s \text { availtible. } \\
\text { Rcduetion made in case of } \\
\text { voluntary unemployment. }\end{array}$ & $\begin{array}{l}\text { Wide range of trrtining schemes. } \\
\text { not fo'mally compulsory }\end{array}$ & $\begin{array}{l}24 \text { hours per week up to } 1992 . \\
\text { Since then, } 16 \text { hours per week } \\
\text { for claimants. but } 24 \text { hours per } \\
\text { week for partners of } \\
\text { unemployed, from October } \\
1994 \text {. }\end{array}$ \\
\hline United Sta-.es & $\begin{array}{l}\text { There is a work test to all programmes } \\
\text { except S51. AFDC must register foe the } \\
\text { JUBs programme. For FS people must } \\
\text { satisfy the work conditions. For (,OA, people } \\
\text { must satisfy conditions. }\end{array}$ & Loss of benefit & $\begin{array}{l}\text { Refusal to cooperate may affect } \\
\text { pitymettl }\end{array}$ & Not stated \\
\hline
\end{tabular}


Most social assistance schemes employ sanctions against those who fail the work tests. As shown in Table 7.4. these range from full loss of benefits either through ineligibility or suspension. or loss of part of benefits for defined periods. There is no indication from the material supplied to us how often these sanctions are applied, or how effective they are judged to be. There are also schemes offering incentives to return to work. or to set up as self-employed. Specific incentives were identified in Australia (from March 1995). Ireland, Luxembourg. the Netherlands. Norway, Sweden, the United Kingdom. and the United States. In most cases. these appear to be small extra supplements, or lump-sum grants, although a number of countries also made available loans and grants under their various special assistance arrangements for people wanting to start up in self-employment. In the United Kingdom a package of work measures was announced in the 1994 Budget. These measures are designed to improve the take-home pay of people working fulltime on modest incomes. and to provide incentives for those seeking work, as well as to boost jobs by reducing costs to employers.

Incentives may also be provided through training and education programmes, although because of the focus of this research we did not collect information on general training programmes in OECD countries. In the majority of countries, it appears that acceptance of job or training offers is compulsory. at least for young people (for example, Belgium, Denmark, the Netherlands, Norway and Portugal). or optional in the case of Finland. Municipalities have obligations to offer employment schemes in Belgium. Denmark, Germany, the Netherlands, Norway, Spain and Sweden. Such schemes appear to be most limited in countries with more restrictive assistance arrangements, such as Austria and Italy.

Finally. Table 7.4 provides details of the operation of 'hours rules' in social assistance schemes. Here it appears that only Ireland and the United Kingdom have rules formally excluding from benefits those working more than a specified number of hours per week. Both countries also. however. have separate in-work benefits which provide help for those working for more hours than the social assistance limits. In all other cases, there are no formal rules. although the operation of the income test generally implies that recipients could only be working part-time. or else recipients are required to be available to take full-time work, if offered. In Australia, there are a range of limits on hours worked by carers, the short-term sick and those with disabilities. but these are designed as tests of primary eligibility.

\subsection{Income tests and related arrangements}

Table 7.5 summarises key features of the income tests operating in social assistance schemes. Most countries appear to provide 'free areas' under which benefits are not reduced, or provide equivalent disregards of income or earnings. The situation is not entirely clear in the case of Iceland, Italy, Japan, Spain, Sweden. Switzerland and Turkey. The rules in Denmark and Finland also appear to allow for some discretion in the provision of disregards, although they are apparently not often applied. Where levels are stated clearly. disregards appear to be lowest in the United States (apart from for Food Stamps), followed by Belgium and the United Kingdom. The disregards seem to be most generous in Ireland. Australia and New Zealand. as well as in Luxembourg. The disregards are set as percentages of earnings in Canada, France and the Netherlands. and as a percentage of the minimum wage in Portugal.

In the majority of countries, social assistance is reduced in relation to net income, although in Australia. Denmark (from 1994). Luxembourg, New Zealand. Portugal and the United States (apart from Food Stamps) it is gross income that is taken into account. Virtually all social assistance schemes operate an income test with a withdrawal rate of 100 per cent. The exceptions are Australia. New Zealand. and Ireland for lone parents since July 1994. Portugal for social pensioners. and the United States, where lower withdrawal rates operate on earnings for SSI and AFDC, and Food Stamps are reduced by only 30 per cent of net income. Clearly. 
arrangements in Australia and New Zealand are the most liberal, although this reflects the absence of social insurance benefits. It should also be noted that in these countries the income taken into account is gross and not net of tax. so that the effective withdrawal rate will be increased over income ranges where income is also subject to tax. The income test - or rather the tax surcharge - - is most relaxed in the ease of recipients of superannuation in New Zealand. It can also be noted that the change to unemployment assistance arrangements in Australia from 1995 will dramatically reduce the withdrawal rate at higher levels of earnings. although the disregards will be reduced at the same time. 


\begin{tabular}{|c|c|c|c|}
\hline & Disregards & Income taken into account & Withdrawal rate \\
\hline Australia & $\begin{array}{l}\text { 'Free areas' for pensioners of A } \$ 44 \mathrm{pax} \text { for singles. A } \$ 76 \mathrm{pw} \text { for } \\
\text { couples, plus ASI2pw for each child. Earnings 'credit' of } \\
\text { A. } \$ 1000 \text { (singles) and A } \$ 2000 \text { (couples). For unemployment } \\
\text { payments, basic free area of A } \$ 30 \mathrm{pw} \text {, plus earnings disregard } \\
\text { of A } \$ 30 \mathrm{pw} \text { for singles and A } \$ 25 \mathrm{pw} \text { for each of couples. } \\
\text { Earnings credit of A } \$ 500 \text { l'rona } 1995 \text {, free area. to be reduced } \\
\text { to A } \$ 30 \ldots \text { but see changes to withdrawal rate. Also partial } \\
\text { individualisation of structure. }\end{array}$ & Gross & $\begin{array}{l}50 \% \text { for older people. those with disabilities, carers, sole } \\
\text { parents. For unemployed, SOY for first } \$ 40 \text { per week, and then } \\
100 \% \text {. From } 1995.50 \% \text {, between } \$ 30 \text { and } \$ 70 \text { per week. and } \\
\text { then } 30 \% \text {. }\end{array}$ \\
\hline Austria & Work expenses tnay be deducted & Net & $100 \%$ \\
\hline \multirow[t]{2}{*}{ Belgium } & $\begin{array}{l}\text { Minimex: general disregard of } £: 17 \mathrm{pm} \text { (US\$27) for families with } \\
\text { children, } £ 8 \text { (812) for couples without children, £14pm ( } \$ 22) \\
\text { for singles. }\end{array}$ & Not clear & $00 \%$ \\
\hline & $\begin{array}{l}\text { Additional earnings disregard of } £ 106 \mathrm{pm}(\$ 168) \text { for first year of } \\
\text { claiming, reducing over time. }\end{array}$ & & \\
\hline ('anada & Partial exemption of earned income & Not clear & $100 \%$ \\
\hline Denmark & Not legally defined. Some of up to $£ 136$ (5216) per month. & Gross from 1994 & 10(] \\
\hline Finland & $\begin{array}{l}\text { Local and infrequently applied directives ....i:3€) } £ 50 \text { per month } \\
(\$ 47 \$ 79)\end{array}$ & Net & \\
\hline France & R.MI: Earnings disregard of $50 \%$ of wage & Not clear & $100 \%$ \\
\hline (iertna€ny & $\begin{array}{l}30 \text { to } 50^{\circ} \text { of household head rate-i: } 45--75 \text { per month } \\
(871-5119)\end{array}$ & Net & $100 \%$ \\
\hline Greece & $\begin{array}{l}\text { Certain types of expense are disregarded when claiming for the } \\
\text { family allowance. These include rent, housing loans and } \\
\text { alimony. The rules are imprecise. Different limits are applied to } \\
\text { the circumstances of different families. }\end{array}$ & Net & One off payments $\left(100^{`} 4,\right)$ \\
\hline Iceland & $\begin{array}{l}\text { Municipalities have discretion to disregard some types of } \\
\text { income such as the income of a child and training allowances }\end{array}$ & Gross & $100 \% \mathrm{f}$ \\
\hline Ireland & $\begin{array}{l}\text { Daily rate of Unemploymen6 Assistance, plus :t:.15 per day } \\
\text { worked (£UKI5.45, \$23.04). } £ 30 \text { per week tor lone parents } \\
(£ 30.90, \$ 46.08) \text {. }\end{array}$ & $\begin{array}{l}\text { Net for VA. Before ta.x and } \\
\text { after social security otherwise. }\end{array}$ & $\begin{array}{l}\text { 100.c generally. All UA lost if fourth day worked St1. for lone } \\
\text { parents from July } 1994 \text {. }\end{array}$ \\
\hline Italy & Not clear & Taxable & $100 \%$ \\
\hline Japan & Part of earnings & Net of tax and social security & 1110"I \\
\hline 1.uxembourg & $\begin{array}{l}\text { Up to } 20 \% \text { of household benefit rate } £ 88 \text { per month } \\
\text { for single person (SI39.90) }\end{array}$ & Gross & I1)0\% \\
\hline Netherlands & $\begin{array}{l}25 \% \text { of net earnings up to } 1511 \text {, of benefit rate for } \mathrm{Al}) \text {. Extra } \\
15 \% \text { for lone parents. }\end{array}$ & Net & $1007 \mathrm{t}$ \\
\hline
\end{tabular}




\begin{tabular}{|c|c|c|c|}
\hline & Disregards & Income taken into account & Withdrawal rate \\
\hline New Zealand & $\begin{array}{l}\text { Income-tested benefits: 550pw or } \$ 6 € I p w \text { with children. } \\
\text { Extra \$2Opw for lone parents with childcare costs. } \\
\text { \$20pw fix earnings for Invalids Benefit. }\end{array}$ & Gross $-\longrightarrow$ & $\begin{array}{l}\text { Income-tested benefits: } 30 \% 0 \text { between disregard and S80pw. } \\
\text { then } 70^{\circ} \text { a Superanniutants: } 25^{\prime} 4 \text { above } \$ 80 \mathrm{pw} \text { (single) and } \\
\text { S6Opw for each of couple, }\end{array}$ \\
\hline Norway & Earnings disregard on Transitional Allowance & $\begin{array}{l}\text { Net of tax and social } \\
\text { insurance }\end{array}$ & $100^{\prime} 6$ \\
\hline Port ugal & $\begin{array}{l}\text { For an individual the monthly income of the individual must not } \\
\text { exceed } 40 \% \text { of the national minimum wage and the average } \\
\text { income of a family must not exceed } 80 \text { ii. For the integration } \\
\text { benefit it must not exceed } 60 \%\end{array}$ & Gross & $\begin{array}{l}\text { Illo", but } 30 \% \text { for single social pension and } 50 \% \text { for social } \\
\text { pension couple }\end{array}$ \\
\hline Spain & $\begin{array}{l}\text { Training allowances and one-off payments from chanties arc } \\
\text { disregarded }\end{array}$ & Net & $100 \%$ \\
\hline Sweden & No earnings disregards & Net of tax & $100 \%$ \\
\hline Switzerland & No formal earnings disregards (though local rules may apply) & Assessment of needs & $1(2 t)$ \\
\hline Turkey & No earnings disregards & Net income & $100 . / \mathrm{i}$ \\
\hline United .Kingdom & $\begin{array}{l}£ 5 \mathrm{pw} \text { for singles and each of couple; ff } 15 \mathrm{pw} \text { for lone parents, } \\
\text { couples under } 60 \text { on iS for two or mote years, carers. disability } \\
\text { premium. Special rules for childminders, and income from } \\
\text { subtenants and lodgers, }\end{array}$ & $\begin{array}{l}\text { Net of tax and NI and } \\
\text { half of pension } \\
\text { contributions }\end{array}$ & $1110 ; 4$ \\
\hline United States & $\begin{array}{l}\text { 5Si: } \$ 20 \mathrm{pm} \text {. } \$(\mathrm{i} 5 \mathrm{pm} \text { of gross earnings, El } 1 \mathrm{U} \text {, and other } \\
\text { payments. AFDC: } \$ 30 \mathrm{p} \mathrm{n} \text {, EPIC, other. FS: } \$ 127 \mathrm{pm}, 20 \% \text { of } \\
\text { household earnings, E.ITC. }\end{array}$ & $\begin{array}{l}\text { Generally gross. Net } \\
\text { for 1-S. }\end{array}$ & $\begin{array}{l}\text { SSE: } 1 \text { ariiinu }, \quad, \quad \text { other } 100^{\circ},, \\
\text { AFDC Earn,;; } \\
\text { FS: } 30 \% \text { x. }\end{array}$ \\
\hline
\end{tabular}




\subsection{Benefit replacement rates}

So far. this chapter has described the rules of social assistance programmes in different countries. The impact of these rules and their implications for behaviour can to some extent be given a quantitative value through the calculation of replacement rates and effective marginal tax rates.

Economic theory distinguishes between two factors that may be relevant to individual decisions to participate in the labour market the income effect and the substitution effect. The provision of social assistance will mean that a given level of income can be maintained without participation in the labour market (the income effect), while the withdrawal of benefits operates as a tax on earnings and reduces the cost of not earning (the substitution effect). However, if the level of social assistance is below the target level of income for an individual, the withdrawal rate may actually encourage further labour market effort, since the individual will have to work more hours to reach their income target (the income effect of the withdrawal rate).

Benefit replacement rates are usually calculated by comparing the levels of statutory entitlements to some measure of income in work (Balderson and Mabbett. 1991: Palme. 1990; Esping-Andersen, 1990), thus showing what percentage of earnings is 'replaced' by benefits. That is:

$$
\text { Replacement rate }=\frac{\text { Income when receiving benefits }}{\text { Income when employed }} \times 100
$$

Replacement rates can be altered either by changes in the level of benefits or by changes to the level of disposable income in work. In a number of countries. there are important schemes to provide in-work benefits, with examples including Family Credit in the United Kingdom, Additional Family Payment in Australia, Family Income Supplement in Ireland, the Earned Income Tax Credit in the United States, Family Support and the Guaranteed Minimum Family Income in New Zealand and a variety of Federal and provincial supplements in Canada. It is notable that these in-work benefits are most common in the English-speaking countriesi and are mainly directed to families with children, although the United Kingdom has announced the piloting of income-supplementation for persons without children. However, some other countries tend to provide extensive systems of income-related housing assistance and more substantial assistance with child-care costs, the effects of which may be broadly similar.

Such in-work benefits are an important component of the armoury of potential programmes to encourage workforce participation. However. it has not been possible to take account of these benefits in the calculation of the replacement rates that follow. since we were restricted to comparing those on social assistance with those on average earnings, and these programmes generally do not operate at that high an income level. For those interested in this issue, relevant figures were collected as part of the earlier study of support for families with children (Bradshaw et at.199;a; Bradshaw, 1995), and these in-work benefits for lone parents are also described in Whiteford and Bradshaw (1994).

It is also important to note that there are some difficulties involved in comparing benefit replacement rates across countries. There appear to be grounds to argue that neither gross nor disposable income are independent of the processes of redistribution in different countries. This argument is developed in detail in Whiteford (1995), but in summary there are significant differences in the level of manufacturing wages in countries with virtually identical levels of real GDP per head - for example, average wages in France are just under 70 per cent of average wages in Denmark, even though the levels of national income are about the same. This appears to be a consequence of differences in the tax structure. with employer social security contributions being shifted on to wages in France, but being virtually non-existent in Denmark. This effect is further complicated because 
disposable income actually means different things in different countries. For example. except for the very poor, health care costs must be paid for out of income after the deduction of taxes in the United States. but in most other countries in our study health insurance is provided by the state and paid for out of taxes and/or social security contributions. Similarly, in the United Kingdom employee contributions to occupational pensions exceed statutory national insurance contributions, but are not usually taken into account in calculating disposable income in replacement rate calculations. In other countries contributions to earnings-related state pension schemes are analogous to occupational or private pension contributions, and these employee social security contributions are netted out of disposable income. In other countries. however. employer social security or occupational pension contributions are important, but ignored in calculation of disposable income. These issues are particularly important when using replacement rates as measures of benefit adequacy. but they may also affect assessments of potential disincentive effects, as discussed below.

This analysis uses the data from the matrix tables. The methods used to derive these data have already been described at the start of Chapter Six. Table 7.6a shows estimates of replacement rates of social assistance (before housing costs) for a range of family types. These replacement rates are calculated by comparing the level of disposable income of persons receiving social assistance with the disposable incomes of the same household type where the head is earning average male earnings. Thus. they will probably understate the real replacement rates of individuals in each country who are actually receiving social assistance. since it could be expected that such individuals would be earning less - perhaps substantially less -- than average male earnin ${ }^{g} \mathrm{~s}$ if they gained a job. This would be even more likely in the case of female lone parents. This abstraction is unavoidable since it was only possible to collect earnings data for cases at the one income level. In any case, the dispersion of earnings varies across countries. Bearing these factors in mind, the results that follow should be considered as a simple measure of replacement rates that may be useful as an indicator of the scope of differences between countries. It needs to be emphasised again, however, that in countries with widely varying local assistance rates. the figures apply only in the specified location.

For single people and couples (aged 35 years). replacement rates are very low in Greece and in Texas and Florida in the USA. They are also quite low in Pennsylvania. Germany. Canada (for single people). and the United Kingdom. Replacement rates are highest in Switzerland. Sweden. the Netherlands, Norway and Denmark. They also appear high in Italy, but, as stated in the previous chapter, these figures have to be regarded with particular caution. For couples with children the highest replacement rates are in the same countries (followed by Australia). For other countries - with the exception of Greece - the presence of children brings quite a large jump in the replacement rate, particularly in Texas and Florida. In general, replacement rates in the UK are around two-thirds of the way down the overall 'league table'. before taking housing costs into account.

Replacement rates for lone parents are generally lower than for couples with children if the lone parent does not have to pay for child care when working. The exceptions are Belgium. Portugal and Switzerland. However. if the working lone parent has to pay for child-care because of the presence of a child under the age of three their replacement rates increase compared with a one-earner couple not requiring child care.

Table 7.6h shows replacement rates after housing costs have been deducted from benefits and net wages. In general. replacement rates will rise where there is additional assistance for housing costs for families on social assistance. In the case of Austria (Salzberg) and Finland this jump in replacement rates is quite substantial. In other cases, notably New York, Greece and Canada (for single people), replacement rates plummet. reflecting high housing costs in relation to the level of social assistance. It is also apparent that replacement rates exceed 100 per 
cent for couples with two children in Austria, Sweden and Switzerland, and for lone parents with a young child in Finland. while they approach 100 per cent for a number of other family types in these countries. In the UK. replacement rates rise somewhat, but its overall position in the ranking does not change much.

The finding that replacement rates calculated after housing costs for some categories of social assistance recipients are over 100 per cent implies that beneficiaries are actually better-off than average full-time workers. However, there is a sense in which these figures may not accurately characterise the relative advantage of employment compared to benefit receipt. First. as emphasised in the previous chapter. housing cost calculations are based on a number of assumptions which may not always emulate the real world. Secondly, as noted above, it appears that in some countries employer social security contributions may be incident upon wages, so that gross and net earnings are systematically lower in countries with high levels of employer social security taxes than in countries with low or no employer social security contributions. It could be argued that employer contributions (including compulsory employer contributions to occupational or private pension schemes) are analogous to employment fringe benefits. That is, an individual in work is accruing entitlements to more generous pensions in retirement. while a recipient of social assistance is receiving no such future benefit. While it is difficult to put a value on such future benefits (Stahlberg, 1986), they imply that effective replacement rates are lower than those shown in this table. But it should be remembered that replacement rates are $\mathrm{al}^{\mathrm{r}}$ eady lower in some countries which also have high levels of employer social security contributions, such as Italy. 
Table 7.6a: Replacement ratios: social assistance as percentage of net disposable income at average earnings, OECD countries 1992 (before housing costs)

\begin{tabular}{|c|c|c|c|c|c|c|}
\hline & $\begin{array}{c}\text { Single } \\
(35)\end{array}$ & $\begin{array}{c}\text { Couple } \\
\text { (35) }\end{array}$ & $\begin{array}{c}\text { Couple } \\
(35)+ \\
1 \text { child } \\
\text { (7) }\end{array}$ & $\begin{array}{c}\text { Couple (35) } \\
+ \\
2 \text { children } \\
\left({ }^{7},{ }^{14}\right)\end{array}$ & $\begin{array}{c}\text { Lone } \\
\text { parent (35) } \\
+.1 \text { child } \\
\text { (3) }\end{array}$ & $\begin{array}{c}\text { Lone } \\
\text { parent }(35) \\
+ \text { I child } \\
\text { (7) }\end{array}$ \\
\hline A ustralia & 31 & 54 & 60 & 67 & 43 & 44 \\
\hline A ustria & 26 & 35 & 46 & 58 & 34 & 34 \\
\hline Belgium & 39 & 47 & 52 & 53 & 56 & 57 \\
\hline Canada & 19 & 40 & 47 & 53 & 45 & 42 \\
\hline Denmark & 54 & 71 & 73 & 78 & 67 & 61 \\
\hline Finland & 23 & 40 & 51 & 65 & 67 & 39 \\
\hline France & 26 & 34 & 41 & 47 & 36 & 34 \\
\hline Germany & 17 & 28 & 36 & 44 & 33 & 30 \\
\hline Greece & 5 & 5 & 5 & 8 & 7 & 7 \\
\hline Iceland & $M a$ & $n / a$ & na & $n$ ॥ & $t t / a$ & $n^{\prime} a$ \\
\hline Ireland & 29 & 41 & 47 & 55 & 44 & 36 \\
\hline Italy & $4^{2}$ & 56 & 65 & 64 & 56 & 53 \\
\hline Japan & ${ }^{2} 5$ & 36 & 46 & 58 & 44 & 42 \\
\hline Luxembourg & 43 & 52 & 58 & 62 & 46 & 46 \\
\hline Netherlands & 58 & 77 & 78 & 81 & 69 & 69 \\
\hline New Zealand & 27 & 46 & 58 & 63 & 49 & 49 \\
\hline Norway & 54 & 72 & 64 & 84 & 58 & 54 \\
\hline Portugal & 44 & 43 & 45 & $=15$ & 68 & 68 \\
\hline Spain & 26 & 28 & 32 & 36 & 35 & 29 \\
\hline Sweden & 58 & 88 & 86 & 102 & 60 & 58 \\
\hline Switzerland & 62 & 89 & 91 & 102 & 77 & 91 \\
\hline Turkey & $m a$ & & $m a$ & $M a$ & $M a$ & $M a$ \\
\hline United $\mathrm{Kin}^{g}$ dom & 21 & 31 & 42 & 51 & 38 & 32 \\
\hline USA $N Y$ & 27 & 39 & 52 & 62 & 48 & 42 \\
\hline USA Pen & 15 & 25 & 40 & 44 & 20 & 29 \\
\hline USA Texas & 6 & 12 & 23 & 43 & 28 & 26 \\
\hline USA Florida & 7 & 14 & 48 & 68 & 45 & 36 \\
\hline
\end{tabular}

Table 7.6b: Replacement ratios: social assistance as percentage of net disposable income at average earnings, OECD countries 1992 (after housing costs)

\begin{tabular}{|c|c|c|c|c|c|c|}
\hline & $\begin{array}{c}\text { Single } \\
(35)\end{array}$ & $\begin{array}{c}\text { Couple } \\
\text { (35) }\end{array}$ & $\begin{array}{c}\text { Couple } \\
(35)+ \\
1 \text { child } \\
\left({ }^{7}\right)\end{array}$ & $\begin{array}{c}\text { Couple (35) } \\
+ \\
2 \text { children } \\
\left({ }^{7}, 14\right)\end{array}$ & $\begin{array}{c}\text { Lone } \\
\text { parent }(35) \\
+1 \text { child } \\
\left({ }^{3}\right)\end{array}$ & $\begin{array}{c}\text { Lone } \\
\text { parent (35) } \\
+1 \text { child } \\
(7)\end{array}$ \\
\hline A ustralia & 34 & 57 & 64 & 72 & 47 & 47 \\
\hline A ustria & 40 & 68 & 84 & 125 & 61 & 61 \\
\hline $\mathrm{B}^{\mathrm{e}}$ lgium & 28 & 35 & 42 & 44 & 46 & 47 \\
\hline Canada & 5 & 35 & 44 & 52 & 40 & 36 \\
\hline Denmark & 41 & 64 & 77 & 80 & 72 & 63 \\
\hline Finland & 42 & 81 & 84 & 96 & 107 & 60 \\
\hline France & 30 & 40 & 49 & 56 & 41 & 41 \\
\hline Germany & 23 & 39 & 49 & 63 & 46 & 41 \\
\hline Greece & 7 & -15 & -14 & -.31 & -16 & 15 \\
\hline Iceland & $M a$ & nia & $n / a$ & $M a$ & $n ! a$ & $n \cdot c$ \\
\hline Ireland & ${ }^{2} 8$ & 46 & 55 & 68 & 54 & 41 \\
\hline Italy & 43 & 58 & 71 & 72 & 60 & 57 \\
\hline Japan & 24 & 37 & 51 & 63 & 49 & 47 \\
\hline Luxembourg & 36 & 44 & 51 & 55 & 37 & 37 \\
\hline Netherlands & 53 & 81 & 83 & 86 & 68 & 68 \\
\hline New Ze,Lland & 18 & 39 & 54 & 61 & 43 & 42 \\
\hline _si $=$ L1y & 34 & 54 & 65 & 82 & 57 & 51 \\
\hline Portugal & 28 & 10 & 4 & 9 & 30 & 30 \\
\hline Spain & 19 & 22 & 27 & 31 & 29 & 24 \\
\hline Sweden & 45 & 89 & 96 & 118 & 59 & 56 \\
\hline Switzerland & 51 & 91 & 94 & 113 & 71 & 97 \\
\hline Turkey & $n^{\prime} a$ & Ilia & $n \cdot a$ & $M a$ & nie & nia \\
\hline$U K$ & 23 & 37 & 49 & 60 & 45 & 37 \\
\hline$U S A N Y$ & & 8 & 30 & 41 & 12 & 13 \\
\hline USA Pen & 15 & 25 & 40 & 44 & 20 & 29 \\
\hline USA Texas & 10 & 19 & 43 & 30 & 22 & 40 \\
\hline USA Florida & -23 & -20 & 23 & 34 & 9 & 10 \\
\hline
\end{tabular}


Before leaving the subject of replacement rates it is worth discussing the relationship between the level of insurance benefits paid to unemployed people compared with the benefits that are available from social assistance. The relationship between the net disposable resources of unemployed families receiving social assistance and social insurance has already been shown in Tables 6.6a and 6.6b.

The ratios give us an indication of the consequences for replacement rates of losing entitlement to social insurance benefits and moving on to social assistance. In those countries with high ratios, the replacement rates will not change very much. Indeed, those countries with ratios in excess of 100 per cent after housing costs will have larger replacement rates when the unemployed person is on social assistance than when they were receiving social insurance. However. in most countries, the level of income is substantially higher on social insurance benefits than social assistance benefits and the replacement rates fall. Thus the rewards of working increase when families move to social assistance benefits. This is one of the reasons why. in considering incentive structures in the benefit system, it is important to cover duration of entitlement as well as the level of benefits.

\subsection{Average effective tax rates and the poverty trap}

As discussed earlier, the other component of an analysis of work incentives is the substitution effect associated with the withdrawal of benefits. These are usually analysed through consideration of 'effective marginal tax rates' (EMTRs) applying to recipients, which are estimated as the sum of the withdrawal rate on benefits and its interactions with any other form of benefit withdrawal, including tax and social insurance contributions. These EMTRs are usually estimated for a small change in labour supply at the margin, looking for example. at what happens if incomes increase by $£ 1$ per week.

I. n this study, we consider average effective tax rates (.AEMTRs), which are estimated over a wider range of income - the difference between zero earnings and average male earnings - as this is likely to be a more realistic illustration of the choices available to individuals, who generally cannot vary their work effort by $£ 1$ increments. Averaging the marginal tax rates in this way tends to disguise narrow income ranges, where marginal tax rates may be particularly high. but where these ranges are narrow the number of people directly affected by them is likely to be small. In contrast, our measure provides an indication of the disincentive effects of moving from not being in paid work to a situation of full-time paid work. That is, they show the effective tax rate applying to a person who moves from a situation of complete 'dependence" on social assistance to a full-time job at average earnings. The calculation takes account of all relevant cash benefits available, plus changes in housing and health costs_ as well as child care costs. where relevant.

An average effective tax rate (AETR) can be defined as follows:

$$
\operatorname{AETR}=\frac{\mathrm{DI}}{\mathrm{E}} \times 100
$$

where DI is the change in disposable income and $\mathrm{E}$ is the change in earnings.

Table 7.7a shows the average effective tax rates before housing costs and Table $7.7 \mathrm{~b}$ shows estimates after housing costs. Effective tax rates are lowest where benefit levels are lowest, since there is less assistance to be withdrawn. Correspondingly, effective tax rates are highest where benefits are relatively high, and exceed 100 per cent in those countries where replacement rates also exceeded 100 per cent. Effective tax rates are higher for those without children than for those with children, although in many cases they are lower for lone parents than for unemployed couples with children. In a number of countries, child care costs add to effective tax rates. Housing costs also increase effective tax rates in all countries apart from Portugal. Spain. and the USA. Again, it should be noted that 
in countries with local assistance schemes the AETRs apply in these areas and not necessarily nationally.

AETRs are different from replacement ratios, but comparison of Tables 7.6 and 7.7 shows that the relationship between the two is fairly constant, both between countries and across family types. The tables show that many of the schemes involve effective marginal tax rates at a level which could act as a disincentive to return to work. The UK, in this respect. performs relatively well. with marginal tax rates below the average for most family types.

Table 7_7a: average effective tax rates for assistance recipients movin ${ }^{\mathrm{g}}$ into work on average earn ${ }^{\mathrm{g}} \mathrm{S}$. OECD countries 1992 (before housin ${ }^{\mathrm{g}}$ costs)

\begin{tabular}{|c|c|c|c|c|c|c|}
\hline & $\begin{array}{c}\text { Single } \\
(35)\end{array}$ & $\begin{array}{c}\text { Couple } \\
\text { (35) }\end{array}$ & $\begin{array}{l}\text { Couple } \\
\begin{array}{l}(35)+ \\
1 \text { child } \\
(7)\end{array}\end{array}$ & $\begin{array}{c}\text { Couple (35) } \\
+ \\
2 \text { children } \\
(7.14)\end{array}$ & $\begin{array}{c}\text { Lone } \\
\text { parent }(35) \\
+1 \text { child } \\
(3)\end{array}$ & $\begin{array}{c}\text { Lone } \\
\text { parent }(35) \\
+ \text { I child } \\
(7)\end{array}$ \\
\hline Australia & 48 & 63 & 68 & 73 & 54 & 54 \\
\hline Austria & 50 & 55 & 60 & 65 & 50 & 50 \\
\hline Belgium & 61 & 62 & 63 & 60 & 70 & 70 \\
\hline Canada & 40 & 53 & 56 & 59 & 57 & 52 \\
\hline Denmark & 76 & 82 & 83 & 85 & 81 & 76 \\
\hline Finland & 38 & 52 & 58 & 69 & 71 & 43 \\
\hline France & 47 & 50 & 53 & 54 & 35 & 45 \\
\hline Germany & 49 & 51 & 54 & 58 & 57 & 52 \\
\hline Greece & 21 & 13 & 13 & 25 & 25 & 21 \\
\hline Iceland & $\mathrm{a}$ & n'a & $\mathrm{n} ? \mathrm{a}$ & $\mathrm{n} / \mathrm{a}$ & nra & $\mathrm{ma}$ \\
\hline Ireland & 54 & 57 & 61 & 67 & 66 & $5^{2}$ \\
\hline Italy & 69 & 68 & 74 & 73 & 69 & 66 \\
\hline Japan & 36 & 41 & 51 & 61 & 55 & 50 \\
\hline Luxembourg & 58 & 60 & 63 & 62 & 52 & 52 \\
\hline Netherlands & 78 & $8^{7}$ & 87 & 88 & 81 & 81 \\
\hline New Zealand & 46 & 61 & 70 & 74 & 63 & 63 \\
\hline Norway & 68 & 79 & 72 & 87 & 64 & 59 \\
\hline Portugal & 54 & 53 & 52 & 50 & 72 & 72 \\
\hline Spain & 40 & 39 & 42 & 45 & 54 & 40 \\
\hline Sweden & 69 & 91 & 89 & 102 & 69 & 63 \\
\hline Switzerland & 74 & 92 & 94 & 102 & 83 & 94 \\
\hline Turkey & $\mathrm{n}: \mathrm{a}$ & $\mathrm{n}: \mathrm{a}$ & $\mathrm{n}$ a & $\mathrm{Ma}$ & $\mathrm{Ma}$ & aria \\
\hline UK & 41 & 47 & 54 & 60 & 57 & 44 \\
\hline USA NY & 44 & 55 & 65 & 72 & 69 & 58 \\
\hline USA Pen & 38 & 48 & 60 & 63 & 25 & 50 \\
\hline USA Texas & 28 & 38 & 53 & 66 & 59 & 49 \\
\hline USA Florida & 34 & 46 & 72 & 85 & 76 & 59 \\
\hline
\end{tabular}

Note: These AETRs are calculated over the $\operatorname{ran}^{\mathrm{g}} \mathrm{e}$ of income between zero earnings and average male earnings. 
Table 7.2b: Average effective tax rates for social assistance recipients Loving into work on avera ${ }^{g} \mathrm{e}$ earnings. OECD countries 1992 (after housing costs)

\begin{tabular}{|c|c|c|c|c|c|c|}
\hline & $\begin{array}{c}\text { Single } \\
(35)\end{array}$ & $\begin{array}{c}\text { Couple } \\
\text { (35) }\end{array}$ & $\begin{array}{c}\text { Couple } \\
(35)+ \\
1 \text { child } \\
(7\}\end{array}$ & $\begin{array}{c}\text { Couple (35) } \\
+ \\
2 \text { children } \\
(7.14)\end{array}$ & $\begin{array}{c}\text { Lone } \\
\text { parent }(35) \\
+1 \text { child } \\
(3)\end{array}$ & $\begin{array}{c}\text { Lone } \\
\text { parent }(35) \\
+1 \text { child } \\
(7)\end{array}$ \\
\hline Australia & 63 & 75 & 78 & 82 & 68 & 68 \\
\hline Austria & 74 & 89 & 94 & 111 & 84 & 84 \\
\hline Belgium & 63 & 63 & 64 & 61 & $7 \mathrm{t}$ & 72 \\
\hline Canada & 49 & 62 & 68 & 73 & 69 & 64 \\
\hline Denmark & 78 & 85 & 90 & 91 & 89 & 84 \\
\hline Finland & 74 & 93 & 92 & 97 & 104 & 76 \\
\hline France & 55 & 61 & 65 & 66 & 45 & 57 \\
\hline Germany & 64 & 69 & 73 & 82 & 78 & 67 \\
\hline Greece & 28 & 23 & 23 & 36 & 35 & 30 \\
\hline Iceland & $\mathrm{t}-\mathrm{a}$ & $\mathrm{n} / \mathrm{a}$ & nia & nia & $\mathrm{n} / \mathrm{at}$ & n: at \\
\hline Ireland & 63 & 70 & 74 & 83 & 80 & 67 \\
\hline Italy & 74 & $\cdot$ & 82 & 82 & 77 & 72 \\
\hline Japan & 51 & 58 & 67 & 78 & 72 & 67 \\
\hline Luxembourg & 58 & 60 & 63 & 62 & 52 & 52 \\
\hline Netherlands & 79 & 91 & 91 & 93 & 84 & 84 \\
\hline New Zealand & 55 & 70 & 77 & 82 & 71 & $7 \mathrm{t}$ \\
\hline Norway & 66 & 77 & 80 & 90 & 72 & 67 \\
\hline Portu ${ }^{\mathrm{g} a l}$ & 5-', & 53 & 52 & 50 & 72 & 72 \\
\hline Spain & 40 & 39 & 42 & 45 & 54 & 40 \\
\hline Sweden & 73 & 95 & 98 & 110 & 77 & 72 \\
\hline Switzerland & 81 & 97 & 98 & 105 & 88 & 99 \\
\hline Turkey & $n-a €$ & n. a & $\mathrm{n} / \mathrm{a}$ & riia & nut & $t^{\prime} \mathbf{a}$ \\
\hline UK & 51 & 60 & 66 & 72 & 68 & 55 \\
\hline USA NY & 52 & 60 & 69 & 77 & 75 & 63 \\
\hline USA Pen & 38 & 48 & 60 & 63 & 25 & 50 \\
\hline USA Texas & 48 & 59 & 80 & 40 & 44 & 74 \\
\hline USA Florida & 34 & 46 & 72 & 85 & 76 & 59 \\
\hline
\end{tabular}

Note: These AETRs are calculated over the range of income between zero earnings and average male earnings,

\subsection{Conclusion}

This study was not designed to explain differences in the impact of social assistance schemes on the labour force behaviour of participants. As a result. the chapter has been primarily descriptive, and has presented some evidence which has a bearing on the possible impact of benefits on labour force participation. It is readily apparent from this discussion that social assistance schemes commonly impose a range of work-seeking requirements on recipients and many offer incentives to return to work or set up as self employed. Nevertheless. many of the schemes involve quite high effective marginal tax rates, which may act as a disincentive to labour force participation. Such potential problems are inherent in any system of income support. although economic considerations are not the only factors involved in claimants' labour market decisions.

It is difficult to discern clear evidence of an association between the level of replacement rates or the stringency of work tests and the level of unemployment. If anything there is a tendency for the countries paying higher social assistance benefits to have tougher work tests and lower levels of unemployment. Thus the Nordic countries tend to have relatively high levels of social assistance, high replacement rates but quite a severe means test with little or no disregards and strong arrangements to encourage labour participation - even by lone parents. It is perhaps also significant that these countries have relatively small-scale and locallyadministered social assistance schemes. It may be difficult to combine strong labour participation policies when social assistance benefits are relatively low and also represent substantial elements of the benefit system for the unemployed. Alternatively. benefits can be perhaps relatively high only when they are not an important component of the benefit system for the unemployed, and when there are active insertion policies. 
In order to investigate these issues further. it would be desirable to have more detailed data on flows on to and off such benefits, but such information is available in respect of only a limited number of these countries. Further exploration of different approaches to encouraging labour force participation requires access to more detailed studies of the range of labour market and training programmes available in OECD countries. 


\section{Chapter 8 Diverse Systems, Common Destination?}

\subsection{Introduction}

This concluding chapter attempts to do four things. First, it brings together the key features of national social assistance systems described in this report in order to identify certain 'social assistance regimes' with common attributes. It is argued that the considerable variety found suggests at least seven different patterns. Secondly. the chapter briefly summarises the evidence from Volume Two about debates and policy issues salient in the different countries. These. it is argued. tend to differ according to the social assistance regime in each country. Thirdly, we attempt an explanation of these findings. in the light of the broad consensus that welfare systems in modern countries all now face common pressures and constraints. We try to show how these common pressures can be reconciled with the national variations which the report has charted. Fourthly. the chapter outlines a framework for the evaluation of these different national systems. We go no further at this stage than to discuss the criteria which might be relevant, with some brief pointers to factors which would need to be taken into account in different countries. Detailed evaluation of assistance systems in the 24 countries would require substantial further work.

\subsection{Patterns of social assistance}

Table 8.1 draws together some of the key features of social assistance arrangements identified in the previous chapters. The indicators selected are not comprehensive, but they provide a summary picture of schemes sufficient to allow us to begin to categorise the countries.

The indicators selected are the following:

- total extent. cost and coverage of social assistance

- the relative level of benefits provided

- the centrallocal dimension in re $^{\mathrm{g}}$ ulation and administration

- the operation of the means test, in particular:

whether the resource unit extends beyond the nuclear family

the tightness of the assets test

the extent to which earnings are disregarded in calculating entitlement to benefit

- the degree of officials' discretion in determining awards.

Another important feature. not recalled in this table. is the extent to which the dominant schemes are general or categorical. Also, as Chapter Seven showed systems vary in the extent to which they encourage or enforce job-seeking activity

-- a dimension which is discussed later in this chapter. 


\begin{tabular}{|c|c|c|c|c|c|c|c|c|}
\hline Country & $\begin{array}{c}\text { Expenditure } \\
\text { as St of social } \\
\text { security (1992) }\end{array}$ & $\begin{array}{c}2 \\
\text { Beneficiaries as } \\
\% \text { of total } \\
\text { population (1992) }\end{array}$ & $\begin{array}{c}3 \\
\text { Composite benefit } \\
\text { levels: } \mathrm{N} \text { from the } \\
\text { mean (after } \\
\text { housing costs) }\end{array}$ & $\begin{array}{c}4 \\
\text { Administrative } \\
\text { and regulatory } \\
\text { framework }\end{array}$ & $\begin{array}{c}5 \\
\text { Resource unit }\end{array}$ & $\begin{array}{c}6 \\
\text { l'reutment of income }\end{array}$ & $\begin{array}{c}7 \\
\text { Treatment } \\
\text { of assets }\end{array}$ & $\begin{array}{c}8 \\
\text { Rights } \\
\text { discretion }\end{array}$ \\
\hline$\underline{\text { Australia }}$ & $\underline{90}$ & $\underline{18}$ & $\underline{28}$ & Federal & $\underline{\text { Fit nily }}$ & 4 (with taper) & $\underline{2}$ & 3 \\
\hline Austria & 5 & I & 2 & Local & Household & & & \\
\hline$\underline{\text { Belgium }}$ & 3 & 4 & & Natllocal & Includes defined relatives & $4 \underline{\text { (time }} \underline{\underline{i} \text { mited })}$ & & \\
\hline$\underline{\text { Canada }}$ & $\underline{14}$ & $\underline{10}$ & & Fcdistate & $i_{\text {arnaly' }}{ }^{\text {ar }}$ & $\underline{3}$ (regional variations) & & 3 \\
\hline Denmark & 8 & & xa & $\overline{\text { Nat/local }}$ & I amily & 4 (discretionary) & 2 & 2 \\
\hline Finland & & 9 & & $\overline{\text { Nafilo-.: a) }}$ & Family & $\underline{\underline{3}}$ (discretionary) & $!$ & 3 \\
\hline France & $\underline{6}$ & $\underline{9}$ & & $\underline{\text { Natt }}-\underline{1 a}:$ & $\overline{\underline{\text { Family }}}$ & $\frac{-\frac{10}{3}}{3}$ & 2 & 2 \\
\hline Germany & $\overline{12}$ & 8 & $\underline{5}$ & $1: \underline{\mathrm{d} /}$ & $\overline{\text { Includes }}$ defined relatives & $\underline{3} \underline{4}$ (re auaaal variations) & ! & $\underline{2.5}$ \\
\hline Greece & $0.9^{-}$ & 1.3 & 119 & Naatllo ai & $\begin{array}{l}\text { Household for lump- } \\
\text { sum assistance }\end{array}$ & 1 & $\dot{\mathrm{n} / \mathrm{a}}$ & \\
\hline Iceland & 1 & 21 & $-\underline{50}$ & 1._isealrNat & $\underline{\text { Family: }^{:}}$ & & & \\
\hline Ireland & 41 & $12^{-}$ & 2 & National & $\overline{\text { Family }}$ & 4 (pl'cgraanane e...eiations) & 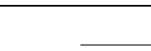 & \\
\hline Italy - & c) & 5 & 28 & L. ocal/Nat & $\underline{\text { Family }}$ & & & \\
\hline Japan $^{-}$ & 4 & l & $\$$ & Nat/local & $\begin{array}{l}\text { Household, includes } \\
\text { defined relatives }\end{array}$ & not clear & & \\
\hline Luxembourg & & & 35 & $\underline{\text { Nat/local }}$ & $\overline{11 \text { oilseho.ld }}$ & 2 & 2 & 1.5 \\
\hline 'Netherlands & $1 \mathrm{I}$ & & & Nat/local & 1 ranily & 2 & 2 & 2.5 \\
\hline$\underline{\text { New Zealand }}$ & $\underline{100}$ & & 18 & Nationa I & $\underline{\text { la,naily }}$ & $\underline{3}$ (with taper) & $\underline{2}$ & $\underline{3}$ \\
\hline$\underline{\text { Norway }}$ & $\underline{5}$ & $\underline{4}$ & $\underline{25}$ & Local/Nat & $\underline{\text { Family }}$ & I & ! & \\
\hline Portugal & $\underline{4}$ & $\underline{2}$ & $\underline{-90}$ & $\overline{\text { National }}$ & $\overline{\underline{\text { F'arnily }}}$ & I & i & 1.5 \\
\hline Spain & $\underline{8}$ & ! & $\underline{41}$ & $\overline{\text { Local!Nat }}$ & $\overline{\text { Family }}$ & ! & $i$ & \\
\hline$\underline{\text { Sweden }}$ & $\underline{7}$ & 1 & $\underline{24}$ & Local/Nat & $\underline{\text { Family }}$ & $!$ & $\overline{\mathrm{i}}$ & $\underline{2.5}$ \\
\hline Switzerland & $\overline{5}$ & $\overline{2}$ & $\overline{41}$ & Local & $\begin{array}{l}\text { Household, including } \\
\text { other relatives }\end{array}$ & 1 (discretionary) & 1 & \\
\hline$\underline{\text { Turkey }}$ & $\underline{\text { nia }}$ & $\underline{\text { nla }}$ & $\underline{\mathrm{n} / \mathrm{a}}$ & Local/Nat & Household & 1 & 1 & 1 \\
\hline UK & $\underline{33}$ & $\underline{16}$ & $\underline{11}$ & Nat & Family & $\underline{2}$ (but taper with Family $\underline{\text { Credit) }}$ & - & \\
\hline USA & 40 & 11 & $\overline{44}$ & Fed/state & $\overline{\text { Household (for Food Stamps) }}$ & $\overline{34} \overline{\text { (varies by programme) }} \overline{ }$ & 2 & vatrie $2 \cdots 3$ \\
\hline
\end{tabular}

Notes and Sources

Columns:

see Table 2.5. Countries marked with an asterisk would record higher spending if income related pension supplements were included. Note also that estimates of social assistance expenditure as a proportion of social security spending (based on OIICD figures) vary in some cases from those produced by national governments. Japan is a particular example. According to their estimates of overall social security spending, $9.5 \%$ went on social assistance.

Table 2.6

Table 6.7b (USA figure: average of the four states). Note that for countries with local variations in benefit levels, these apply to specific locations.

Chapter 4

Table 3.2

Table 3.2

Table 3.2

Chapter $4 . \mathrm{I}=$ full discretion exercised by officials; 3 = virtually no discretion and effective appeals. 2 between these two. 
Looking first at the extent and the generosity of social assistance schemes. summarised in columns 1-3, we can see that these two dimensions are not correlated across OECD countries (see Figure 8.1). The extensive social assistance programmes in the English-speaking countries deliver generous benefits in Australia and very low benefits in the USA' ${ }^{\prime}$. There are similar variations in those countries with low or modest reliance on social assistance. Switzerland, for example. which relies mainly on insurance-based schemes for social protection and thus has one of the least extensive social assistance programmes in the OECD area. records the highest level of benefits (at least in the Canton of Fribourg). The Scandinavian countries also all provide relatively generous benefits, vet southern European countries with similarly minimal reliance on assistance deliver very low benefits. The remaining EU member states deliver roughly average benefit levels. apart from Luxembourg and the Netherlands, which fall into the more generous group. As emphasised in Chapter Six, the data on benefit levels for local assistance in Italy are somewhat uncertain. at least for non-pensioner households.

Ingore S.I: A typology - extent and generosity of social assistance

\begin{tabular}{|c|c|c|c|}
\hline & & Extent of & assistance- $^{\circ}$ \\
\hline & & Extensive & Minor-modest \\
\hline & $>\mathrm{I} 70^{\prime}: \%$ & Australia & $\begin{array}{l}\text { Iceland, Switzerland, Luxembourg, Netherlands, } \\
\text { Finland.. Denmark.. Norway, Sweden. (Italy) }\end{array}$ \\
\hline $\begin{array}{l}\text { Level of } \\
\text { benef its' }=\text { ? }\end{array}$ & $100-120 X^{\prime \prime}$ & $\begin{array}{l}\text { UK, I I eland, } \\
\text { Canada }\end{array}$ & Japan. France \\
\hline & $\begin{array}{l}75-10\left(1^{\prime} 4\right. \\
<80 \mathrm{e}\end{array}$ & $\begin{array}{l}\text { New Zealand } \\
\text { USA }\end{array}$ & $\begin{array}{l}\text { Austria, Belgium. Germany } \\
\text { Spain. Portugal. Greece. Turkey }\end{array}$ \\
\hline
\end{tabular}

Notes:

Extensive $=>30$ ' -ii social security expenditure, and/or $>1 D^{\prime}:>$ population

Average net disposable incomes on social assistance (after housing costs) for ail family= types (except single person aged 17) as proportion of mean for all countries.

These differences also correlate with the national differences in the reliance on general or categorical schemes. summarised earlier in Tables 2.1 and 3.1. Among the English-speaking countries, Britain relies chiefly on a single giant programme and Canada has one overarching structure through the Canada Assistance Plan. though with substantial provincial variation (which is set to increase under the new Canada Health and Social Transfer funding arrangements). Australia. New Zealand, Ireland and the USA. on the other hand, feature several group-specific programmes. In the rest of the OECD. the Scandinavian countries. Netherlands. Austria. Germany and Japan also rely primarily on general assistance programmes. while all the remaining countries of Europe, plus Turkey, have some or many different categorical programmes. Each of the two patterns can be found with more or less generous provision.

There is another contrast between schemes which are nationally uniform and those which show regional or local variations. To begin with, it helps to demarcate federal states, where regional or provincial governments have a constitutional role. from unitary states. In the USA and Canada. there is considerable inter-state variation in benefits and eligibility. and in the Swiss confederation responsibility is located at the Cantonal and communal level. Spain too. while not constitutionally a federal state, allows its regions considerable autonomy. which includes the provision of minimum income protection. However, in the two remainin ${ }^{\mathrm{g}}$ federal states - Australia and Germany ---- there is little or no variation. Otherwise, there is a general contrast between the liberal, English-speaking countries and the rest. All of the former have national or national-state legal and administrative frameworks. At the other extreme. in south-western Europe (excluding Greece). Sweden, Norway, Iceland, and Austria (and notably in Switzerland. mentioned above) local governments have considerable power in provision of assistance. In

\footnotetext{
"We should note, though.. that benefits in New York state are above average and tli:,-.e in Pennsylvania are below-average but not in the lowest category, indicating the very wide spread o benefits in the USA. One might say that the South, Middle and West of the USA are uniquely low in the level of benefits in the English-speaking countries
} 
Finland. Denmark. Netherlands. Germany, France, Belgium and Japan. the central government provides a national framework of regulation within which local administrations operate.

The next level of variation is whether the resource unit extends beyond the nuclear family to embrace other household members or wider kin networks. With a few exceptions, modern systems of social assistance have retreated from the 'household means test' and kin liability. The exceptions are the German-speaking countries (Germany. Austria and Switzerland), Belgium, Luxembourg, Japan and Turkey, all of which either include other household members in the calculation of needs and resources (as does the Food Stamp programme in the USA). or, at least in theory, hold certain categories of other relatives liable for payment, or both.

The extent to which earnings are disregarded in the means-tests is another critical measure. Table 8.1 distinguishes three categories. First are those countries with relatively high earnings disregards - Australia, New Zealand, most programmes in the USA, together with Belgium and Germany. Denmark could perhaps be included here. though its relatively high guideline disregards appear rarely to be applied. At the other extreme are those countries with no earnings disregards at all

Southern Europe and Turkey. Austria and Switzerland. In between are countries like the UK, with low basic disregards, but the taper introduced by Family Credit, and the majority of assistance schemes in Ireland. It is not clear where Japan fits into this pattern, as the level of their disregards is not known.

Another important facet of the means test is the treatment of assets. Table 8.1 reproduces the results of findings from Chapter Three, to make a rough divide between those nations where most assets are counted and those where there are relatively high disregards on assets, in particular dwellings. Here the patterns are surprising. A less strict pattern of treatment is found in the extensive social assistance regimes of the. English-speaking world, with the exception of US prớrammes - particularly AFDC. Greater leeway on savin ${ }^{g_{s}}$ and owner-occupied homes is also common in many countries of the EU. though less so in the limited assistance regimes of the Mediterranean world. It appears to be in Scandinavia (except perhaps Denmark), Austria and Switzerland that the toughest tests are found.

Lastly. there are two partly related features - the degree of discretion in the award of benefits and the extent to which there are effective rights of appeal. At one end of the continuum are the English-speaking countries with established appeals mechanisms. where the discretion of officials tends also to be minimised. In Finland, Sweden. Luxembourg. the Netherlands and Germany applicants enjoy a similar degree of codified rights. At the other end are countries where individual officials and/or local municipalities enjoy considerable discretion in the award of benefits. These include most of the Mediterranean countries, Austria, Switzerland and Norway. Japan appears to be somewhere in the middle, with national regulations and appeal rights, but retaining a degree of officer discretion in the assessment of entitlements.

Can any pattern be identified in this welter of difference? To a certain extent it can, but it is not a simple pattern. This section concludes by grouping like countries together.

\section{Selective well are systems: Australia and New Zealand.}

These countries are unique in that all benefits are means-tested. There are several categorical programmes. nationally organised, inclusive and rights-based. The means-testing is carefully constructed and monitored and is implemented in a consistent way. Assets and earnings disregards are relatively generous. However, there is a significant gap in the value of benefits between Australia (relatively generous) and New Zealand (below average since 1991). 


\section{The public assistance state: USA.}

The USA exhibits an extensive set of means-tested benefits, arranged in hierarchy of acceptability and stigma. Assets tests are generally tough, but there are in-built earnings disregards and work incentives in every scheme. Benefits are variable but tend to be low both in comparison with other countries and in relation to domestic poverty lines. Procedural rights. on the other hand, are well entrenched. This picture must be qualified in certain states, including New York and most of New England. Minnesota and Wisconsin. California. Washington. Hawaii and Alaska. Here benefit levels are around the OECD average, though other features of US assistance remain the same.

3. $\quad l^{w}$ elfare states with integrated safety nets: Britain. Canada. Ireland and Germany.

This is a varied group of countries. but one with sufficient common factors to place them together. Income Support in the UK. is a large, national. general programme providing an extensive safety net at or below social insurance levels. When Housing Benefit is included. levels of payment are above the OECD average. Rights to benefit are relatively well entrenched and the means test contains important disregards, with some work incentives for people with children through Family Credit. Ireland is at first sight a mix between this and the antipodean pattern. There are numerous categorical assistance schemes covering a high proportion of the population with means tests and entitlements on a par with those in Britain. However, it is moving towards a more integrated system.

Both Canada and Germany are federal states and thus exhibit regional variations. These are considerable in Canada. but in other respects the Canadian Assistance Plan has had much in common with social assistance in Britain. Under the new funding arrangements coming into effect from 1996 onwards, however, the picture is likely to change. Germany has also developed in a similar way. thou ${ }^{\mathrm{g}} \mathrm{h}$ from different historical antecedents: Soiatlailfi' isi despite its federal-Land structure, geographically equitable. codified, rights-based. extensive and of average generosity ${ }^{1 i}$.

4. Dual social assistance: France and the Benelux countries.

These countries provide categorical assistance schemes for specific groups, but have supplemented these with newer programmes providing a general basic safety net. Local discretion remains, but is now firmly placed within a national regulatory framework. Assets tests are moderately flexible. as are earnings disregards. But benefit levels vary considerably between generous Netherlands and Luxembourg. and below-average Belgium.

\section{Rudimentary assistance: Southern Europe and Turkey.}

National categorical assistance schemes cover certain specific groups. mainly elderly and disabled people. Otherwise there is Iocal, discretionary relief provided by municipalities or religious charitable bodies (nationally regulated in Greece and Turkey). Means testing is not especially stringent and, apart from in Turkey, obligations do not extend beyond the nuclear family. Money assistance tends to be integrated with social work and other services. Benefits are very low or. for some groups and geographical areas. non-existent.

\section{Residual social assistance: the Nordic countries.}

A tradition of full employment and universal welfare provision has relegated social assistance to the margins of social programmes in these countries - or rather, it did

" The argument of Lodemel and Schulte (1992) for putting Germany in a separate category turns on the existence of a separate programme for the unemployed, which is in practice a peculiar hybrid of social insurance and assistance, and the existence of wider family obligations. This last is a distinguishing feature of the German-speaking countries in Europe, but appears to be of limited significance. Yet in other respects Germany can also be viewed as a bridge to the fourth group of countries below. 
so until sharp rises in unemployment hit Denmark in the late 1980s. . and Finland. Iceland and Sweden in the 1990s. Each country has a single general scheme with relatively high benefit levels. Though there are national regulatory frameworks (to varying degrees), the role of local authorities is substantial and Iinks with social work and social care persist. Strict means-tests combine with a view of family financial responsibilities which place more emphasis than in most countries on the individual, particularly in relation to cohabitation. General citizenship-based appeal systems modify the discretionary aspects of assistance in all countries except $\mathrm{N}$ orwav.

\section{Highly decentralised assistance with ieee1 discretion. Austria and Switzerland}

These countries contain elements of both the Nordic and Southern European models. I.n the Alpine countries, assistance consists of localised, discretionary relief, linked to social work and with wider kin obligations. However, benefit levels are above average _ in Switzerland the most generous in the OECD, on the basis of the particular local authority and canton studied. Yet relatively small numbers of people claim social assistance. This is partly because of a record, at least until recently, of full male employment. However, take-up also appears to be low, which is attributed to stigma and the substantial powers of intervention accorded to local social welfare workers.

Japan is difficult to place in this typology. In certain respects it resembles category 3 , the states with integrated safety nets, in that it has a long-standing, nationallyregulated system, with above average benefits and only moderate local variation. Expenditure is on a smaller scale than in these countries, however, but larger than in Austria and Switzerland, with whom it shares the wider concept of family obligation and the more comprehensive household means test. There are arguments, therefore, for placing it in a category of its own.

It is evident that the social assistance regimes tentatively outlined here bear only a distant resemblance to Esping-Andersen's typology of welfare regimes, in particular to his measures of welfare state stratification (1990. Chapter Three). His first, liberal' group of countries comprises the English-speaking countries, plus Japan and Switzerland. This cannot provide a framework for understanding social assistance programmes for the following reasons. First, the role of assistance is qualitatively different in Switzerland in particular, so much so it cannot be grouped with the English-speaking countries in any taxonomy of social assistance regimes. Secondly. as Castles and Mitchell (1993) point out, his treatment of Australia and New Zealand overlooks the very different principles of selectivity which they embody, and the higher level of benefit equality which they generate. Selectivity in Australasia is sui geneuis. Thirdly. the security, level and uniformity of the safety net is considerably weaker in most states of the USA than in Britain. Canada and Ireland. Though all countries in the English-speaking world exhibit extensive assistance regimes, they differ substantially in other respects.

Esping-Andersen's 'social democratic' world of welfare capitalism comprises countries with universal benefits and substantial redistribution: the Nordic countries plus the Netherlands. Apart from the Netherlands, these exhibit similar patterns of social assistance --- or at least did so until the recent rapid growth in unemployment in all of them except Norway. This, together with some similarities between this ${ }^{\mathrm{g}}$ roup and the other economies with relatively full employment in group seven above, suggest that employment regime may be as important as welfare regime in explaining their common features.

His third world of 'corporatist' welfare rests on occupational, contributory insurance schemes which reproduce stratified and differentiated benefit levels. The archetypical countries are Germany, Austria, Belgium. France and Italy. Here too, there cannot be found a single mode of assistance provision. Germany, we argue, is the only continental European country which has made the transition to a comprehensive. unified and rather extensive assistance safety net. Of the rest. we 
distinguish three groups, comprising north-western Europe, Mediterranean Europe and Austria. Other factors would appear to mediate the links between E.spingAndersen's principles of welfare state stratification and the social assistance regimes we have identified.

The careful study of means-tested benefits therefore muddies. but ultimately enriches, prior comparative models of welfare systems (cf. Gough. 1994).

\subsection{Debates and policy initiatives}

Using the record of current national debates and policy initiatives presented in Volume Two. it is possible to consider whether these are similar across countries, or whether they reflect the different regimes of social assistance noted above.

The English-speaking countries with extensive social assistance do report a range of issues in common. These include the cost of assistance, work disincentives. fraud and the issue of targeting. A variety of policy initiatives have been developed to tackle each of these, some of which are discussed below. In addition, however, a concern with the extent of poverty continues to feature in political debate in a way that is unusual in most other countries. In all countries, except the USA, the high level of unemployment is also a cause for concern.

These patterns are to be expected given the high cost of programmes and the large welfare clienteles in this group of countries. However_the question of behavioural incentives in welfare -- to discourage marriage or remarriage and to encourage teenage pregnancy and welfare dependency more generally - appears to be a defining feature mainly of the stigmatising and divided public assistance system of the USA. The concept of assistance as creating a new 'underclass' is relatively absent in Australia and New Zealand, and while present in debates in Britain and Canada it has not achieved ideolo ${ }^{\mathrm{g}}$ ical dominance.

The issues of programme costs, fraud and incentives do figure in some other countries, notably those with relatively high spending levels and numbers of recipients -- Germany and the Netherlands ....... or where recent unemployment is forcing more people on to assistance rolls as in Sweden and Finland today. In France and Belgium, where unemployment is higher and benefits are lower. there is also an ongoing debate about poverty and the role of targeted benefits plus work programmes in alleviating it. There is thus some overlap with the agenda of the English-speaking world.

A variety of other concerns feature in contemporary debates over social assistance. In the Northern European countries, outside Scandinavia. these include the rights of immigrants and asylum seekers to social assistance benefits. In Germany and Austria, the transfer of the costs of institutional and domiciliary care for the frail elderly from social assistance to social insurance is a live issue. In all the Scandinavian countries, a major issue of debate concerns the future role of social workers in the assessment and delivery of cash benefits: growing caseloads have posed strains on social workers and initiated a debate reminiscent of that in Britain fifty years ago. There is also a growing consensus in all these countries except Norway that more national regulation and uniformity should override traditional local autonomy in social assistance. The same is true. to some extent, in Switzerland, though there are no immediate indications that policy will move in this direction. Lastly. in some of the southern European countries there is still another agenda, which concerns the practicalities of introducing a national safety net for the first time__ in part a response to the European Commission's Draft Recommendation (Commission of the European Communities, 1991). .However there is little immediate prospect of development on this question in any of the countries. 
Overall. therefore, it is possible to see some relationship between contemporary debates and policy initiatives and the types of social assistance regime identified above.

\subsection{Common pressures and national responses}

Though there are disagreements, students of the welfare state agree on certain economic changes affecting the environment of modern welfare states (see for example, Pfaller et rrl.. 1991; Pierson. 1991; Taylor-Goohy, 1991_Esping-Andersen, 1994: OECD. 1988. 1994a). One of these sets of factors concerns changes in the economic environment, includin ${ }^{\mathrm{g}}$ the glohalisation of production, the rise of the emerging economies of East Asia. de-industrialisation. the exposure of governments to global financial markets and (for some) the end of the capacity of states to design their own political economic regime. One commonly perceived casualty of these shifts is full employment in its traditional sense and the emergence of atypical work. Moreover, pressures mount to cut labour costs, both direct and indirect, in advanced economies, with impacts on taxation, public finances and public spending. These pressures on the labour market and fiscal policy pose questions about traditional features of the welfare state in general and social assistance in particular.

One set of political changes concerns the effect of rising affluence and changing life styles on consumption patterns: it is contended that these undermine political support for traditional universal programmes in favour of differentiated services. Another school of theorists emphasises the effect of growing inequality and new divisions in society on older patterns of solidarity and the impetus for the more affluent to exit from state programmes. Either way. it is argued. political support for inclusive patterns of social provision ebbs.

The particular pressures driving policy change in the area of social assistance can be seen as falling into two groups: first those deriving from forces external to the structure of benefit systems themselves, and secondly those resulting from internal features of policy systems.

New demands from external. $j$ areas

demography

Although changing demographic patterns particularly population ageing _ are widely seen as posing a severe challenge for public pension systems, the so-called 'demographic crisis' actually impinges remarkably little on debates about the future of social assistance. This is because in most OECD countries social assistance spending on older people represents a declining share of an already small proportion of total expenditure on social security. The incomes of older people in many countries have increased, partly because of the maturation and improvement of pension schemes. and in a number of countries even poorer older people are protected from having claim assistance by the presence of minimum, noncontributory citizens' pensions. It is the future viability of insurance pension schemes themselves which most excites political debate in many countries of the world.

Older people are more likely to be receiving assistance in the English-speaking countries, where social assistance covers larger proportions of the population. However, the population structures of Australia, New Zealand, the USA, Canada. and Ireland are relatively youthful, whilst the UK has already effectively undergone much of the ageing process. In Australia, there has been some increase in the targeting of pensions. In New Zealand, a more concerted attempt to restrain expenditure has been made, including the taxation of benefits and their de-linking from earnin ${ }^{g}$. Yet even here, demographic pressures do not in themselves appear to be significant causes. 
Where ageing is impacting on social assistance, it is in the area of long-term care of older people. which has been creating considerable difficulties in Austria, Germany and the UK, in particular. This has led to policy responses such as the creation of the new long-term care insurance in Germany, whil.e in the UK older people are having to rely to a greater extent on their own private resources.

\section{- changing family structures}

Fundamental shifts have occurred in the role of women, which impact both on the labour market and on family structure. The rise of divorce, lone parenthood and other non-traditional family forms are examples of common trends, despite significant structural differences across nations. More young people are living apart from their families, which is likely to be one reason why increasing numbers of assistance recipients in some countries are young, single people. One policy response, in the UK. has been to reduce the availability of benefits to people under 18 , unless in demonstrable hardship.

Ideas about family obligations and relationships more generally have also been shifting. The rise of cohabitation. for example, has led some countries, such as the Netherlands. to review its payment structure for people sharing households and to shift the burden of proof of non-cohabitation more on to claimants. Cohabitation in the Nordic countries, on the other hand, seems to be regarded as unproblematic in relation to social assistance.

\section{- labour market change}

The importance of increasing unemployment - and particularly long-term unemployment_as a factor in increasing claims for social assistance has already been emphasised. The changing nature of the labour market in all the industrialised countries has also reduced opportunities for unskilled work, necessitating more pro-active approaches to re-training and job creation. The concentration of longterm unemployment amongst unskilled workers also leads to potential 'social exclusion', as the social and labour market difficulties of assistance recipients multiply and deepen. Policy approaches to deal with these problems are considered in more detail below.

\section{- $\quad$ rising housing and fuel cost problems}

Another significant factor driving the increase in costs of social assistance in some countries is a rise in housing costs. In the UK, for example, expenditure on Housing Benefit has risen faster than that on Income Support. not primarily because the number of claimants has grown dramatically, but because it has been Government policy to allow rents to rise closer to market levels. Similar pressures have been experienced in a number of other countries.

Pressures f-om within the policy systems

A number of related pressures which impact on social assistance policy stem from within the structure of social security systems themselves. These include:

\section{- the breakdown of traditional social insurance coverage}

Limits to duration of unemployment insurance mean that with longer-term unemployment fewer people are covered. With higher youth unemployment, there are more unemployed young people without entitlement to insurance benefits. This is alleviated in some countries __ in particular, the Benelux countries _-.._by giving education leavers special entitlement to short-term, non-contributory insurance benefits. The growth in lone parenthood has also exposed gaps in insurance coverage.

\section{- pressures on public expenditure}

Pressures on public expenditure on social programmes is common to all the countries in the study to some degree. In most countries where social assistance 
represents only a minor expenditure. costs have not in themselves been a major issue. but containment of expenditure on other insurance programmes is sometimes leading to increased claiming of assistance benefits.

The individual country chapters in Volume Two, and Chapter Four in this volume. show how in several of the countries with centralllocal cost-sharing for social assistance there has been pressure on local authorities to assume greater responsibility for expenditure. This has happened either through direct reductions in central ${ }^{\mathrm{g}}$ overnment subsidies, as in Canada from 1996 onwards. or by local authorities being given cash-limited block funding for exceptional needs expenditure. as in the Netherlands. Such changes may lead to greater geographical variation or inequity, as some of the areas with the most difficulty financing assistance are also those with the hi ${ }^{\mathrm{g}}$ hest numbers of claimants.

\section{- public sector staffing}

A related issue of costs applies to the staffing of public sector welfare agencies. There is a general pressure to simplify systems that are complex and staff-.intensive, as is often the case in social assistance. In the countries with a tradition of linking social work intervention closely with cash assistance. however, such a pressure results in tensions between a streamlined income maintenance role and the traditional casework approach. Such tensions have been particularly evident in the Nordic countries.

it was stated above that unemployment and labour market change were amongst the factors driving policy on social assistance. We now consider in more detail the different policy approaches to job search activity and work incentives.

\section{Unemployment and work incentives}

The pressures outlined above impinge on social assistance programmes in two main ways. First, as we have seen, rising unemployment drives more people to claim social assistance as their entitlement to unemployment insurance benefits (where they exist) is exhausted. Secondly. concern has ${ }^{\mathrm{g}}$ rown that assistance programmes create disincentives to find work and leave welfare beneficiaries in an unemployment trap'. This in turn exacerbates unemployment and boosts social expenditure.

These concerns have stimulated the search for ways to make the welfare system more compatible with the changing labour market, itself driven by shifts from an industrial to some form of post-industrial employment pattern. Policies can be loosely grouped into two familiar categories - 'carrots' and 'sticks'. 'Carrots' include reducing the withdrawal rate of benefits as earnings rise, providing education, trainin ${ }^{\mathrm{g}}$ and work experience programmes for jobless claimants, and extending child care and other benefits to enable claimants with caring responsibilities to combine these with paid work. 'Sticks' include enhanced monitoring of able-bodied claimants, stricter tests of job-search activity with sanctions for non-compliance. time-limited benefits and straightforward reductions in relative benefit levels.

It would appear from a reading of debates in the English-speaking world that this set of issues has dominated discussions about the future of social assistance. However, comparative study suggests a more variegated pattern. Let us consider the tw o trends in turn. First. the pressure of rising long-term unemployment on claimant numbers can certainly be observed in several countries. These include: Canada. New Zealand, the UK. Ireland, France. Germany. Netherlands and Belgium during the 1980s, and Sweden and Finland in the 1990s. However, not surprisingly. we do not find such pressures in those countries with better job records, including Australia, the USA. Luxembourg, Norway, Austria and Japan (and Finland and Sweden before 1990). Nor is this the case in Denmark and 
Switzerland, where other benefit programmes appear largely to have held up, or in the Mediterranean countries where assistance for the long-term unemployed is very limited. The end of full employment, if such it is, impacts differently according to both labour market and welfare regime.

Secondly, debates over work disincentives and policy proposals to deal with them vary across the najor forms of assistance regime identified above. They can be grouped into four sets for this purpose

- Those countries with a past record of full or near-full employment (the Nordic countries, Switzerland, Austria and Japan), here work incentives have not been a matter of political debate (though they are emerging as such in Denmark and Sweden) it is interesting to note that in all of them claimants are allowed to work whilst receiving benefits, provided that their income does not exceed the permitted level, Such policy shifts as have occurred in the Nordic countries are primarily of the incentive type, Including child-care provision, the Youth Allowance programme in Denmark and extraordinary work programmes in Norway. Developments in the other three countries are less clear, as they depend on more individualised and discretionary approaches.

- The limited social assistance regimes of southern Europe, including Turkey: lere the debate on labour market disincentives is less relevant. Social assistance for the able-bodied of working age is vestigial and its impact on local labour markets likewise slight. This is not to say that issues of work incentives are not relevant to certain unemployment insurance programmes, such as that of Spain. There has been some experimentation with work and integration schemes in Italy, Portugal and Spain, but their implementation has been patchy.

- The remaining EU member states (excluding the UK and Ireland) here a growing concern with the new poverty and social exclusion in the $1980 \mathrm{~s}$ has fuelled experiments with integration programmes. The RMI in France, Minimex in Belgiun, the re-integration programme in the RMG in Luxembourg have all targeted young unemployed people and tied improved benefit levels to insertion in training and work experience schemes, However, this combined carrot and stick approach appears to have only a matginal impact, and the issue appears to be of relatively low political salience, except in France, In the Netherlands, with nore generous benefits and typically weak links between social security and the labour narket, there has been some tightening of work requirements for lone parents. Germany has not developed special insertion schemes, preferring to rely on its already well-established mechanisms for training and work placements.

- The extensive social assistance states of the English-speaking world (including bilingual Canada) it is in these countries that the relation between assistance and the labour market has assumed greater importance in policy debates, Yet even here Ireland is an exception, with few major proposals or policy changes of any import New Zealand has opted for a variety of measures to make claiming less attractive, notably absolute cuts in benefit levels, especially for inemployed claimants.

The remaining countries in this group have adopted a mixture of carrot and stick. The carrots include higher benefits and partial individualisation of income support for couples (Australia), a substantial extension of Earned Income Tax Credit, nore generous tapers and help with child-care and medical care costs for lone parents and others who take up paid work (the USA), extensions and extra disregards within Family Credit and a package of back-to-work provisions (the UK), and, in Canada, 'employment enhancing measures' a new child tax benefit and time-limited wage supplements. 
The sticks have included more intensive requirements for job-search activity in all countries in this group. In addition, Britain is to introduce the new Jobseeker's Allowance, which further reduces the insurance element of unemployment protection and enhances work seeking requirements. Benefits and entitlements in the USA were reduced in 1981, and training requirements have been extended again in the 1990s. Following the recent mid-term elections, debate and policy proposals have become more punitive. Republican congressional leaders have called for time-limited benefits for AFDC claimants. yet without federally-funded work programmes, and for public orphanages for those children whose parents cannot support them (The Economist, 19 November 1994).

Overall. the pattern of response to common economic pressures is complex. In many respects the differences are to be expected, ${ }{ }_{\text {iven national differences in }}$ labour markets, social assistance regimes, political complexion and broader social traditions. The prominence of work incentives in policy debates is certainly greater in countries with greater reliance on social assistance. Yet even within this group, differences are noticeable between the Australian selective welfare state and the American public assistance state.

\subsection{Evaluating national assistance regimes}

Having observed patterns of debate and policy response to common political and economic pressures, it is necessary to reflect on how the variety of social assistance arrangements currently in operation across the OECD area can be evaluated on a comparative basis. We do not attempt a full-scale evaluation here. This was not within our original remit and could not be carried out within the time and resources available. Nevertheless, some discussion is appropriate of the criteria according to which national assistance programmes might be evaluated. There appear to be three main options.

First, we might specify and use the actual objectives which inform the operation of individual social assistance schemes in each country. There would be merit and logic in comparing performance to policy objectives in this way, but it would reveal very little. in so far as policy objectives are framed at all for social assistance, they are often at a level of generality which would make it difficult to measure their achievement. The greater the number of countries to be included in the framework. the greater also will be the diversity of more specific objectives. Within each country the relationship between social assistance and other elements of the social protection package is mediated by the structure and form of government. the level of unemployment, the demo ${ }^{\mathrm{g}}$ raphic profile and the overall size of the economy. The OECD countries satisfy certain basic criteria for admission to the organisation, but beyond that member states vary in many significant respects. One of the findings of the study is that social assistance programmes are too diverse for such a relative measuring rod to yield comprehensible results.

Secondly, we might identify certain benchmark criteria, as used in one country, and apply them to the schemes in the other countries. For example, we might turn to the elaboration of general 'aims, priorities and objectives', as presented by the UK Department of Social Security (1995). These include: that benefits should focus on the most needy: that there should be minimum disincentive effects within the benefit system: that the benefit system should be as simple as possible; that benefits should adapt to the differing needs of people rather than the other way around; that fraud and abuse should be kept to a minimum: that personal responsibility should be encouraged". Two observations must be made at this stage. First. these priorities and objectives are not criteria for the evaluation of either efficiency or effectiveness. There is no indication of what methodological procedures or data would be required to relate outcome to objectives systematically. Secondly, they are

\footnotetext{
4 These stategic priorities and objectives are presented in the context of the British social security system and not just the social assistance component. However, and by definition, several may be considered to apply to the objectives and operation of social assistance schemes.
} 
primarily internal objectives for the benefit system, without any broader view of what the outcomes of social assistance are meant to be. Such a view, of course. relates to the elaboration of wider policy and societal objectives: these are not always made explicit, in the United Kingdom or elsewhere. However, in some countries they are made more explicit. For example, the Australian government proposes a set of specific objectives for social policy within the context of a wider statement of objectives for social justice (equity, equality, access and participation). Quebec, among the Canadian provinces, also specifies objectives for its social assistance schemes.

Nonetheless, it would not be appropriate to derive evaluative standards from the objectives of any one territory, whether the United Kingdom, Australia. Quebec or anywhere else. There is no reason to suppose that even if valid criteria could be identified they would be relevant elsewhere.

The third approach is to construct evaluative criteria from first principles. We are not the first to seek benchmarks against which to measure social security schemes (Meade, 1978; NCC, 1984). Schulte (1994) has also used criteria derived particularly from a legal and administrative perspective to compare social assistance schemes. In a recent comprehensive survey, Barr (1992) has identified three categories of objectives for social institutions: efficiency, equity or supporting living standards, and administrative feasibility. These dimensions, formal and abstract, can be elaborated to suggest an evaluative framework for the comparative assessment of social assistance.

Barr argues that efficiency has the following aspects:

( Macro efficiency: the proportion of GDP committed to total social protection should avoid distortions which generate inflation.

( $\quad$ Micro efficiency: policy should ensure the efficient division of total welfare state resources between the different programmes. This applies to the division between social insurance and social assistance benefits.

B Incentives: the range of benefits should minimise adverse effects on labour supply, employment, saving and other forms of behaviour. The number and extent of 'traps' (savings, unemployment, poverty, disability) should be minimised if not eliminated.

His second strategic aim. 'supporting living standards', is wide-ranging and can be sub-divided into at least seven ${ }^{g}$ oals:

- Poverty relief: within any country or society no individual/family/household should fall below a prescribed minimum. However, the choice of standard is normative. The effectiveness with which this objective is achieved may be measured by the numbers falling below the prescribed level (a simple head count); or by how much below these people fall (the poverty gap) and for how long they are below the poverty line (life cycle/duration).

- Protection of accustomed standards: no one should experience an unexpected or dramatic fall in livin $\mathbf{n}^{\mathrm{g}}$ standards. Social assistance should provide protection and security against contingent events such as unemployment, disability, death of a bread-winner - either on a continuing or one-off basis. An indicator would be a replacement rate of income before and after a given life event.

(B) Income smoothing: structures and policies should enable individuals to reallocate their consumption over their lifetime. Assistance should be available when needs are acute (for example when there are young children, or costs associated with illness or disability).

- Vertical equity: the system should redistribute toward individuals or families with lower incomes. By definition, social assistance payments are 
made to the poor and not the rich, and to that extent they automatically contribute to this goal_ provided that their financing is progressive.

() Horizontal equity: benefits should take account of family size, age and composition. This requires that appropriate equivalence scales are applied to benefit rates to reflect differences in families' needs. Also, circumstances such as the extra costs of disability or illness should be taken into account when assessing the level of benefit.

( $\quad$ Dignity: policies and services should preserve individual dignity and should not engender unnecessary stigma. The difficulty here is in defining di ${ }^{\text {gnity }}$ and stigma and finding relevant indicators.

( ) Social solidarity: social programmes should seek to promote cohesion and to reduce exclusion. This objective too is fraught with definitional and measurement difficulties.

Lastly, administrative feasibility entails the following two objectives:

® Simplicity: the system should be simple, easy to understand and as cheap as possible to administer. Indicators might include administrative costs as a proportion of benefit expenditure, error rates in adjudication. kiwis of take-up or evidence of claimant satisfaction.

(B) Absence of abuse: there should be minimal fraud. Indicators might include estimates of the extent of fraudulent activity and the numbers of prosecutions.

It is apparent that these criteria are numerous, that each of them is complex and that some are difficult to put into operation. This is especially so with respect to social assistance programmes which serve people who are frequently vulnerable or marginal within the societies in which they live. The above criteria would have to be interpreted sensitively to reflect the experience of users. Nevertheless, Barr ${ }^{\mathrm{i}} \mathrm{s}$ list suggests the sort of measuring rods which would need to be applied if a normative comparison of social assistance systems is to be undertaken.

Yet this approach also faces practical and conceptual problems. First, even within a national context there are frequently limits to what is analytically possible because of data deficiency. The absence of detailed, accurate or recent data on the funding of social assistance, the characteristics of claimants, the impact on labour supply. the treatment of urgent or exceptional needs and the role and responsibilities of non-governmental organisations are all areas where information is patchy. Secondly. there is no fundamental agreement on basic definitions: social security, let alone the more specific term social assistance, means different things in different countries. Within and between countries there are differences over the meaning and measurement of poverty, inequality and unemployment. Thirdly, even if indicators for specified outcomes could be found, a further problem remains: the causal relationship between objectives inputs. outputs and outcomes will remain unclear. Indeed. such apparent relationships lie at the heart of important debates about dependency, underclass and incentives. Fourthly. it could be argued that these criteria give too little attention to the consequences of aspects of the administrative structure of social assistance, including rights and discretion. or local variation - aspects which Schulte (1994) emphasises.

\subsection{Conclusion}

This study has compared the structure and operations of arrangements for providing minimum income protection in 24 countries of the OECD. The research has found that as a form of social security, resource-tested social assistance is becoming more important in nearly all the countries studied, both in terms of expenditure and claimant numbers. There are wide differences in the form and structure of provision, while there are also similarities. By comparing key characteristics, it is possible to create a typology of social assistance regimes, which in some respects is consonant with previous efforts. but in others cuts across them. 
While policy debates also vary, there are a number of issues which are salient in most countries to varying degrees. particularly that of work incentives. Perhaps the clearest distinctions, however. between different countries' arrangements for social assistance, apart from the level of benefits provided, are whether they are organised on a national or local basis, and whether needs are met through one general inclusive scheme or on a cate ${ }^{\mathrm{g}}$ orical basis.

Such differences raise questions about how the performance of different schemes can be evaluated comparatively. We have discussed some criteria for how schemes might be judged, though it was not within our remit to carry out such an evaluation in this study. Nonetheless, we hope that it provides the beginnings of an empirical basis for that task to be attempted. 


\section{References}

Atkinson, A. (1989) 'Social insurance and income maintenance'. pp.104 $\cdots 124$ in Poverty and Social Security, Hemel Hempstead: Harvester Wh.eatsheaf.

Atkinson. A. (1992) The Western Experience with Social Safety Nets, Welfare State Programme Discussion Paper WSPI80, London: London School of Economies' STICERD.

Atkinson. A. (1993) On Targeting Social Security: Theory and Western Experience with Family Benefits. Welfare State Programme Discussion Paper WSP/99, London: London School of Economics/STICERD_

Atkinson, A. and Mogensen. G. (993) Welfare and Work Incentives: A Noral European Perspective. Oxford: Clarendon Press.

Ayala, L. (1994) 'Social needs, inequality and the welfare state in Spain: trends and prospects'. Journal of European Social Policy, 4, 3. pp.159-179.

Bardone, L. and Degryse,E. (1994) 'Poverty and social protection in the European Union'. Paper for the ISSA International Research Meeting Social Security: a Time for Redefinition?, Vienna, 9-11 November 11994.

Barr, N. (1992) 'Economic theory and the welfare state', Journal of Economic Literature, Volume XXX, pp.741-803.

Beckerman. W. (1979) Poverty and the Impact of Income Maintenance Programmes, Geneva: International Labour Office.

Beveridge, W. H. (1942) Social Insurance and Allied Services, Cmd. 6404. London: HMSO.

Bodart. M. and Dijon, X. (1990) Recours conire les decisions des CPAS en matiere df.Minimex et daide soci llE:: profit du fonctionnement des Tribunaux du Travail et de Chambres de Recoarrs. Leuven.

Bolderson, H. and Mabbett. D. (1991) Social Policy and Social Security in A ustralia, Britain and the USA. Aldershot: Avebury.

Bradbury, B. (1993) 'Family assistance, replacement rates and the unemployment of 'married men'. A ustralian Bulletin of Labour, 19, 12, pp.114--132.

Bradshaw, J. (1994) 'Simulating policies: an example in comparative method', paper presented at the MIREMaison Francaise conference Comparing Social Welfare in Europe, University of Oxford. May 1994.

Bradshaw. J. (1995) 'The level of social assistance in 18 countries', Benefits.

Bradshaw, J. and Lynes, T. (1995) Benefit (,prating Policy and Living Standards. Social Policy Report No.1, York: Social Policy Research Unit.

Bradshaw. J., Hicks, L., and Parker. H. (1992) Summary Budget Standards for Six Households. Family Budget Unit. Working Paper No 12., University of York. 
Bradshaw, J.. Ditch, J.. Holmes. H. and Whiteford. P. (1993a) Support for Children: a Comparison of Arrangements in 15 Countries. DSS Research Report No. 21. London: HMSO.

Bradshaw, J., Ditch, J., Holmes, H. and Whiteford, P. (1993b) Exceptional needs. social assistance and discretionary, additions in 15 countries, SPRU Working Paper DSS 1052, York: Social Policy Research Unit.

Breuer, W. and Engels. D. (1993) Der Abstand_wisehen derv Leistungsniveau der I"Iilfe um Lebensunterhalt ncah derv BSIIG and den verflagbaren arbeitneehrnereinkomrnen enterer Lohn-und Gehaltsgruppen in July 1992. Cologne: ISG.

Brooke Ross, R. and Zacher, H. (1983) Social Legislation in the Federal Republic of Germany, London: Bedford Square Press;'NCVO.

Brown, J., Hausman, P. and Kerger. A. (1991) Recommendations on Common Criteria Concerning Sufficient Resources and Social Assistance in the Social Protection Systems, Luxembourg: CEPS/INSTEAD.

Cameron, D. (1985) 'Public expenditure and economic performance in international perspective', in Klein. R. and O'Higgins, M. (eds) The Future ()J Welfare, Oxford: Basil Blackwell.

Castles. F. and Mitchell, D. (1.991) Three worlds of welfare capitalism or four?, Australian National University Discussion Paper 21. Canberra: ANU.

Cockx, B. (1992) The Minimum Income Guarantee: some views from a d?'namic perspective, $\mathrm{PhD}$ Thesis. Faculteit Economische en Toegepaste Economische Wetenscappen, Leuven: University of Leuven.

Commission of the European Communities (1991) Recommendation on common criteria concerning sufficient resources and social assistance in the social protection systems, Draft Recommendation by the Council COM(91) 161, 13 May, Brussels.

Commission of the European Communities (1994a) White Paper---- European Social Policy: A Way Forward for the Union, Luxembourg: Office for Official Publications of the European Communities.

Commission of the European Communities (1994b) White Paper - - - Growth, Competitiveness, Employment: The Challenges and Ways Forward into the 21st Centw' $t$. Luxembourg: Office for Official Publications of the European Communities.

Commission on Social Justice (1994) Social Justice.- Strategies for National Renewal. London: Verso.

Commission on Social Welfare (1986) Report of the Commission on Social Welfare. Dublin: Stationery- Office.

Commission van der Zwan (1993) Het recht op hijstand. near een beheerst proces toekenning van hiJstand, rapport van de Onder_oekscommissie toepassing ABU/. Den Haag: Ministerie van Sociale Zaken en Werkgelegenheid.

Carden, A. (1995) Changing Perspectives on Bernfit Take-Up, SPRU Papers, London: HMSO.

Craig, G. (1993) Replacing the Social Fund. a Strategy or Change, York: University of York. 
Craig. P. (1991) 'Costs and benefits: a review of take-up of income-related benefits', Journal of Social Policy, 20, 4, pp.537-566.

Deacon. A. and Bradshaw, J. (1983) Reserved for the Poor. Oxford: Martin Robertson.

Deleeck. H.. Van Den Bosch. K. and De Lathouwer, L. (1992) Poverty and Adequacy of Social Security in the European Community. Aldershot: Avebury.

Deleek. H., De Lathouwer, L.. Van den Bosch, K., Berghman. J.. Estivill, J., Kaptevn. A.. Muffels, R.. Ray, J.-C.. Schaber. G.. Whelan. B. and Yfantopoulos, J. (1991) Indicators of Poverty and Social Security: methodological considerations and comparative results for seven countries. Luxembourg: Eurostat.

Department of Health and Social Services (1985a) Reform of Social Security: Vol.!, Cmnd. 9517. London: HMSO.

Department of Social Security (1993) Social Security Statistics 1993, London: HMSO.

Department of Social Security (1994) Income Related Benefits: estimates of take-up in 1990 and 1991. Analytical Service Division. London: HMSO.

Department of Social Security (1995) Social Security Departmental Report: the Government's Expenditure Plans 1995/6 to 1997/8, Cm 2813. London: HMSO.

Ditch, J. (1994) 'Next Steps: restructuring the Department of Social Security', pp.64--83 in Page. R. and Deacon. N. (eds) The Costs of Welfare, Aldershot: Avebury.

Ellwood, D. (1988) Poor Support: Poverty in the American Family, New York: Basic Books.

Esping-Andersen, G. (1990) The Three Worlds of Welfare Capitalism Cambridge: Polity Press.

Esping-Andersen, G. (1994) 'After the Golden Age: welfare and employment in open economies'. Synthesis paper for UN Social Summit, UNRISD.

Eurostat (1993) Basic Statistics of the European Community: 3Oth Edition. Luxembour $^{\mathrm{g}}$ : Statistical Office of the European Communities.

Euvrard, F. (1989) 'Minimum income schemes: practical lessons', Paper presented at the European Conference on Basic incomes, 15-17 November, Cumberland Lodge, UK.

Evans, P. (1994) Response to social assistance expert questionnaire (Canada).

Finn. D. (1994) 'US welfare reform: ending welfare as we know it, Working Brie 59, November, pp.9 12.

FIora. P. (eel) (1987) Growth to Limits: The $f^{\circ}$ estern European Welfare States since World War IL Volumes 1-4, Berlin: Walter de Gruyter.

Fridberg, T. (eel) (1993) On Social Assistance in the Nordic Capitals. Copenhagen: Danish National Institute for Social Research.

Fry, V. and Stark, G. (1987) The take-up of supplementary benefit: gaps in the safety net', Fiscal Studies, 8. pp.1-14.

Gough, I. (1979) The Political Economy of the Welfare State, London: Macmillan. 
Gough, I. (1994) Means-testing in the western RR'orld, Richard Titmuss Memorial Lecture, Hebrew University of Jerusalem, 31 May.

Gould, A. (1993) Capitalist Welfare Systems: A Comparison of Japan, Britain and Sweden, London: Longman.

Guillaume, M.-L_(1994) Response to social assistance expert questionnaire (Switzerland).

Gustaffson, B. and Lindblom, M. (1993) 'Poverty lines and poverty in seven European countries, Australia. Canada and the USA', Journal of European Social Policy. 3, 1. pp.21-38.

Hagenaars. A., de Vos. K. and Zaidi, M. (1994) Patterns of Poverty in Europe. Paper presented at the 23rd General Conference of the International Association for Research on Income and Wealth. St Andrews, Canada. August 21-27.

Hauser, R. (1993) 'Approaches to comparative social policy analysis'. in Berghman. J. and Cantillon. J. (eds), The European Face of Social Security. Aldershot: Avebury.

Heidenheimer, A.. Heclo. H. and Adams, C. (eds) (1990) Comparative Public Policy, 3rd edition, New York: St Martins Press.

Huyse. L., Remy, D. and Sabbe, H. (1991) In heroep gain tegen een OCMWbeslissing: rapport van een under oek bij tiers provinciale heroepskamers (met speciale aandacht voor de positie van vreemdelingen), Leuven: KUL.

Huhtanen, R. (1994) Toimeentulotuen myontiiminen Tampereen yliopisto (dissertation investigating appeal cases handled by the County Court in Finland).

Ibbs Report (1989) Improving Management in Government: The Next Steps, London: HMSO.

Karagiorgas, S., Kasimatis, K. and Pantazidis, N. (1990) Dimensions of Poverty in Greece, Vols $A$ \& B, Athens: National Centre of Social Research.

Kerr, S. (1983) Making Ends Meet: an investigation into the non-claiming of supplementary pensions. London: Bedford Square Press.

Lambrechts. E. and Dehaes, V. (1986) Het OCMW en de onderhoudsp/icht: E'en enquete hij 224 Vlaamse OCMWs over kosten en terugvorderingen, Brussels: Centrum voor Bevolkings__ en Gezinssstudien.

Lauronen. K., and Lehto, J. (1991) Kunnallinen toirneentulotuki Alkuan joukkotyonomyyoen Oldissa. Sosiaali-ja terveryshallitus. Aiheita 10/91.

Layard. R., Nickell, S. and Jackman, R. (.1991) Unemployment: Macroeconomic Perfor, nance and the Labour Market, Oxford: Oxford University Press.

Lehto J. and Lamminpaa, K. (1992) Ruuhkaa ja Ieikattua perusturvaa toimeentulotukiluukulla Sosiacali, ja terveyshallitus raportteja 75, Helsinki: VAPK Publishing.

Lewis, J. (1992) 'Gender and the development of welfare regimes". Journal of European Social Policy'. 2, 3, pp.159-173.

Liebfried. S. (1991) Towards a European Welfare State: on integrating poverty, regimes, Centre for Social Policy Research Working Paper No.2, Bremen: University of Bremen. 
Lodemel. I. (1992) 'European Poverty Regimes', paper presented at the International Research Conference on Poverty and Distribution, Oslo, 16 November 1992.

Lodemel. I. and Schulte, B. (1992) 'Social assistance: a part of social security or the Poor Law in new disguise?' Paper presented at the conference Social Security Fifty Years after Beveridge, University of York. 27-30 September.

Mannion, R., Hutton. S. and Sainsbury, R. (1994) An Evaluation of Direct Payments from Income Support, DSS Research Report No. 33. London: HMSO.

Mantysaari, M. (1993) 'Toimeentulotuki- viimesijainen suojaverkko vai ensisijainen turvajarjestelmU' in Heikkild. M. et al. (eds) Hvvinvoinnin pcicitepysiikillci, STAKES raportteja 12811993, Helsinki: VAPK Publishing.

Marsh. A. and McKay. S. (1993) Families, Work and Benef London: Policy Studies Institute.

Meade. J. (1978) The Structure and Reform of Direct Taxation, London: Institute for Fiscal Studies.

Miller, S. and Tomaskovic-.Dewey. D. (1990) 'Targeting processes', Research in Social Policy. Volume 2. JAI Press. pp.91---117.

MISSOC (1992) Social Protection in the Member States of the Community. Colo ${ }^{g}$ ne: ISG.

MISSOC (1993) Social Protection in the MemberStates of the Community. Cologne: ISG.

Mitchell, D. (1991) IJ'elfrare States and Welfare Outcomes. Aldershot: Avebury.

Mitchell, .D., Harding, A. and Gruen, F. (1994) 'Targeting welfare - a survey', The Economic Record, 210, September, pp.315-340.

National Board of Health and Welfare (1994) The Social Services and Care in Sweden. Stockholm: Socialstyrelsen.

National Board of Health and Welfare (1995) Additional information supplied by officials.

National Consumer Council (1984) Of Benefit to All: A Consumer Review of Social Security, London: NCC.

O'Connor. J. (1973) The Fiscal Crisis of the State, New York: St James Press.

O'I-liggins. M. and Jenkins, S. (1989) 'Poverty in the EC: estimates for 1975, 1980 and 1985', in Eurostat. Analysing Poverty in the European Community, Luxembourg: Eurostat.

Organisation for Economic Co-operation and Development (1988) The Future of Social Protection, Paris: OECD.

$\mathrm{Or}^{\mathrm{g}}$ anisation for Economic Co-operation and Development (1992) Main Economic Indicators. Paris: OECD.

Organisation for Economic Co-operation and Development (1993) Employment Outlook. Paris: OECD.

Organisation for Economic Co-operation and Development (1994a) The Jobs Study: Facts, Analysis, Strategies. Paris: OECD. 
Organisation for Economic Co-operation and Development (1994b) New Orientations for Social Policy, Social Policy Studies No.12, Paris.

Organisation for Economic Co-operation and Development (1994c) Employment Outlook, Paris: OECD.

Organisation for Economic Co-operation and Development (1994d) Household Transfer Database, Paris: OECD.

Overbve, E. (1994) Comparative Review of Social Insurance and Social A ssistance Schemes in Europe, Oslo: National Institute of Social Research.

Palme. J. (1990) Pension Rights in Welfare Capitalism: The development of old-A ge pensions in 18 OECD countries, Stockholm: Swedish Institute of Social Research.

Petmesidou, M. (1991) 'Statism, social policy and the middle classes in Greece', Journal of European Social Policy. 1, 1, pp.31-48.

Pfaller. A.. Gough, I. and Therhorn, G. (1991) Can the Welfare State Con petc Comparative Study of Five Advanced Capitalist Countries, London: Macmillan.

Pfeil. W. (1994) Response to social assistance expert questionnaire (Austria).

Pierson, C. (1991) Beyond the Welfare State: the new political economy of the welfare state, Cambridge: Polity Press.

Rainwater. L., Rein. M. and Schwartz, J. (1986) Income Packaging in the Welfare State. a comparative study of Jiunilt' income. Oxford: Clarendon Press.

Ramprakash, D. (1994) Poverty in the countries of the European Union: a synthesis of Eurostat's statistical research on poverty'. Journal of European Social Policy, 4, 2, pp.1 17-128.

Roberts. S. and Bolderson, H. (1993) How closed are we/Dare states? Migration and national frontiers. - a case study' of social security provision for non-nationals in three EC countries, Brunel University, July, mimeo.

Room, G. (1990) New Poverty' in the EC, London: Macmillan.

Rowntree, B. S. (1937) The Human Needs of Labour (hew Edition), London: Longmans Green.

Russell. N. and Whitworth, S. (1992) Benefits A gency National Customer Survey 1991, DSS Research Report No.10. London: HMSO.

Saporiti. A. (1994) Response to social assistance expert questionnaire (Italy).

Saraceno. C. (1990) Observatory on Policies for Combating Social Exclusion: National Report: Italy, Torino: Dipartimento di Scienze Sociali, Universit ${ }^{\mathrm{y}} \mathrm{di}^{\mathrm{a}}$ Torino.

Saunders, P. (1991) 'Selectivity and targeting in income support: the Australian experience', Journal of Social Policy, 20, 3. pp.299-326.

Saunders, P. (1994) The Role, Value and Limitations of Poverty Research, Social Policy Research Centre Discussion Paper No.53. Sydney: University of New South Wales.

Saunders, P. (1995) 'Improving work incentives in a means-tested welfare system: the 1994 Australian social security reforms'. Fiscal Studies. 16, 2. pp.47---70. 
Scherer, P. (1978) 'The perverse additional worker effect' . A ustralian Economic Papers, 17, 32.

Schulte, B. (1994) 'Social assistance rationale and techniques', Paper given to a conference and discussion forum organised by the Hilscher Social Policy Association and Eotroes Lorand University, Budapest. 18-20 March.

Smeeding, T., Saunders, P., Coder. J., Jenkins, S., Fritzell, J., Hagenaars, A., Hauser, R. and Wolfson. M. (1992) Non-cash Income, Living Standards and Inequality: Evidence from the Luxembourg Income Stud LIS Working Paper, Walferdange: CEPS INSTEAD.

Smith, N. and Wright, C. (1993) The Benefits A gency Customer Surrey 1992, Leeds: Benefits Agency.

Sohara, T. (1985) 'Tei-shotoku setai to seikatsuhogo' (Low-income households and public assistance) in Shakaihosho. K. (ed) Fukushi-sesisaku no Kihon /Vandal' (Fundamental Problems of Welfare Policy), Tokyo: University of Tokyo Press.

Stahlherg, A.-C. (1986) 'Social welfare policy__ nothing but insurances?', Discussion Paper 6/1986, Stockholm: Swedish Institute for Social Research.

Steiner. H. (1994) Response to social assistance expert questionnaire (Austria).

Stephens, R. (1994) Response to social assistance expert questionnaire (New Zealand).

Stjerno, S. (1995) Mellom Kirke og Kapital, Oslo: L niversitetsforlagetiUniversity Press.

Tanninen. T. and Julkunen, I. (1993) Eliirnaei scidstrilekillci (life in frugality'), STAKES tutkimuksia 3211993, Helsinki: VAPK Publishing.

Taylor-Gooby. P. (1991) Social Change, Social Welfare and Social Science, Hemel H empstead: Harvester Wheatsheaf.

Terum, L.-I. (1994) Response to social assistance expert questionnaire (Norway).

Townsend, P. (1992) The International,4.ncalt sis of Poverty, Hemel Hempstead: Harvester Wheatsheaf.

Tsakoglou. P. (1993) `A critical presentation of empirical investigations of the phenomenon of poverty in Greece paper presented to the Third Social Policy Conference. Sakis Karaviorgas Foundation, Athens, 26---29 November 1991.

van Huffel. C. (1990) Beroep tegen OCMW-heslissingen in_ake bestcaansminiraaum en aatschappelijke dienstverlening: Profel van de arbeidsrechtbanken en van de beroepskamers van Vlaanderen, Leuven.

van Oorschot, W. (1991) 'Non take-up of social security benefits in Europe', Journal of European Social Policy, 1, I, pp.15-30.

van Oorschot, W. (1995) Take It Or Leave It: a study on non-take-up of social security benefits, Aldershot: Avebury.

van Oorschot, W, and Schell, J. (1991) 'Means testing in Europe: a growing concern', in Adler, M., Bell, C.. Clasen. J. and Sinfield, A. (eds) The Sociology of Social Security. Edinburgh: Edinburgh University Press. 
van Oorschot, W. and Smolenaars, E. (1993) Local Income Assistance Policies: The Dutch case and a European impression. Work and Organisation Research Centre. Tilburg University, Paper 93.07.011;28.

Veit-Wilson. J. (1994a) Dignity Not PoveFts, London: Institute for Public Policy Research.

Veit-Wilson. J. (1994b) -Comparing governmental minimum income standards', paper prepared for a seminar at the Work and Organisation Research Centre of the Department of Social Sciences. Tilburg University. The Netherlands. 2 June 1994.

Voges. W.. and Rohwer. G. (1992) 'Receiving social assistance in Germany: risk and duration'. Journal of European Social Policy, 2, 3, 175-191.

Wagner, A. (1994) Response to social assistance expert questionnaire (Luxembourg).

Whale. A. (1993) 'Voluntary welfare provision in a landscape of change: the emergence of food banks in Auckland', MA Hons. Thesis, Department of Geography. University of Auckland.

Whiteford, P. (1994a) 'Welfare targeting'. Parliamentary Brief, 2, 5. pp.58" 9.

Whiteford, P. (1994b) 'Measuring the impact of social policy: a comparative analysis of the well-being of older people', D.Phil. Thesis_ unpublished, University of York.

Whiteford. P. (1995) The Use of Replacement Ratios in International Comparisons of Benefit Systems, Social Policy Research Centre Discussion Paper No.54, Sydney. University of New South Wales.

Whiteford. P. and Bradshaw, J. (1994) 'Benefits and incentives for lone parents: a comparative analysis', International Social Security Review, 3-4;94. pp.59-89.

Whiteford, P. and Kennedy. S. (1995) Incomes and Living Standards of Older People: a Comparative Analysis. DSS Research Report No. 34. London: HMSO.

Wilensky, H. (1975) The Welfare State and Equality: Structural and Ideological Roots of Public Expenditure, Berkeley: University of California Press.

Woldringh, C., Miltenburg, T., and Peters. M. (1987) Landurig in de bijstand. Nijmegen: Tnstituut voor Toegepaste Sociologic (ITS).

World Bank (1990) World Development Report 1990. Oxford: Oxford University Press. 


\title{
Appendix Model Families Income Matrix
}

\author{
UNIVERSITY OF YORK \\ Social Policy Research Unit \\ INTERNATIONAL COMPARATIVE STUDY OF SOCIAL ASSISTANCE \\ SCHEMES: THE SOCIAL ASSISTANCE INCOME MATRIX
}

\section{Introduction}

As part of our comparison of social assistance across countries. we wish to be able to prepare quantitative estimates of the value of social assistance benefits for individuals in specified circumstances. It is very important that these estimates are prepared in exactly the same way in all countries, so that the final results can be comparable. We would like you to fill in the attached data matrix, which will enable us to make these comparisons.

If you have any questions about this data matrix, or if you require any further explanation of the circumstances of individuals in the matrix, please contact Tony Eardley by phone or fax.

In this matrix we want you to calculate the monthly disposable cash income of a number of households that differ in size and composition. These are 'model' or hypothetical families. It is possible that the circumstances described in the matrix are not realistic in your country, or that few people will actually be in the circumstances described. Nevertheless, it is very important that you follow all the assumptions that are spelt out or the results will not be comparable across countries. If you would like to comment on the representativeness of these assumptions. or if there are particular issues in your country that affect interpretation of the results, please write them down on a separate page.

We are trying to understand the structure of social assistance in your country and the relationship between social assistance and other forms of income. We are therefore interested in how much social assistance would be received by individuals and families in the specified circumstances. These calculations are to be made in the first matrix, labelled 'Category 1'. We also wish to compare the situations of people receiving social assistance with those of people with the same family characteristics but different levels of income. We are interested therefore in two further sets of calculations - 'Cate ${ }^{\mathrm{g}}$ ory 2 ' covers people who are not working but who receive social insurance benefits, on the basis that they have contributed to social insurance funds. 'Category 3 ' covers a number of individuals and families who are in full-time work as employees in manufacturing industry.

We are asking you about more than just cash social assistance, since our previous research in this area found that there are other important forms of protection available that can have a significant impact on the economic well-being of households receiving social assistance benefits. You will see from the matrix tables that we wish you to identify assistance with housing costs and with local taxes, the impact of health care costs, and the impact of school costs and pre-school child care costs, where relevant.

In some countries there may be no set rates of social assistance payments made to certain family types, even in specified locations, either because there are no 
assistance benefits at all or because payments are discretionary. Where you would expect no payment to be made at all you should indicate this. Where there is no set rate, please enter an amount which you would realistically expect a family in the specified circumstance to receive and explain in a note how you have arrived at this fi ${ }^{\mathrm{g}}$ ure.

For those countries which were part of the previous study of child support you will see that substantial parts of the tables have already been filled in. The figures are derived from the data obtained in that study. We would be grateful if you could check the entries for accuracy. They may not always be precise because they have been derived by reconverting rounded pounds sterling back into the original currency, using purchasing power parities. Please let us know if they appear to be more than five per cent out. For other countries some figures have been entered which are derived from published international data. Again we would be grateful if you would check the accuracy of this data.

\section{General assumptions}

The first point to note is that all incomes and benefits are those applying at May 1992. All components should be expressed in monthly terms in your own national currency. If benefits are actually paid weekly, then the weekly rate should be multiplied by 52 and then divided by 12 . If the rate is fortnightly, multiply by 26 and then divide by 12 , and so on. In the case of factors that are calculated on an annual basis --- perhaps income tax -- we want you to calculate the tax payable as if the monthly income were to be received for the whole tax year. This will involve you 'scaling down' the income tax schedule for your country to its monthly equivalent. We understand that this may have some implications for persons receiving social insurance benefits, which we will ask you to identify later.

\section{Location}

All cases in each category of the matrix should live in the same city or town. In order to be able to synthesise this information with that acquired for some countries in the earlier comparative study of child support, we need to keep the same locations for these countries. Also, because of known regional or local variation in benefits paid in some countries we have already specified certain areas for the official questionnaire. For your country we therefore need the location to be .................. The housing costs and local taxes should reflect actual practice in this city or town. The rates of social assistance should also be those actually applying in this city or town.

\section{Housing}

All cases are assumed to be living in a rented dwelling. Please assume that this is the most common form of renting in your chosen area, whether it is provided by a public authority, a housing co-operative or a private landlord. Please assume that all categories are renting the same type of dwelling, depending on the number of people in the household. Please assume:

1. Single people are renting a one-bedroom dwelling.

2. Couples with no children or with one chilth and lone parents with one child are renting two-bedroom dwellings.

3. Couples with two children are renting a three bedroom dwelling.

The gross rent payable should be the average rent for these types of dwellings in the city or town chosen. Net rent should be after the receipt of any relevant housing benefits or rent rebates.

Please note, we understand that these assumptions may be highly unrealistic in your country. We need to have the same assumptions in all countries, however, so that any housing benefits that exist are calculated on as similar a basis as is possible. We will be presenting results before and after cases pay their housing 
costs, so that in those countries where these assumptions are unrealistic we will still be able to compare incomes before housing costs. There is space at the end for you to indicate your views on these assumptions.

\section{Local taxes}

Please calculate the gross local taxes that cases in the location you have chosen would have to pay. If sewerage, garbage collection, water charges or other charges are not included in these taxes. do not calculate them. What we want to find out here is whether there are any programmes that reduce the impact of local taxes, so also calculate the net local taxes that cases would have to pay after receiving these benefits.

\section{Health costs}

For each case we want you to calculate how much the specified household would have to pay for a standard package of health care. This package is as follows:

- $\quad$ each person (including children) in the household makes three visits to a general practitioner in a year,

S each person is prescribed a standard antibiotic three times in each year,

o each person spends one week in hospital per year, and

(B) each person has one visit to a dentist in the year and has one tooth filled.

Once again we realise that this might not be particularly realistic. but it is important that you calculate the costs of a standard package. Please note that these should be net charges. That is, calculate how much each case would pay and subtract any reimbursement from the Government. If it is common in your country for households to take out private health insurance, then the costs of these premiums should be included in the charges. These should be added to the fees paid by the household, and the reimbursement that the health insurance company would provide should then be deducted.

After you have calculated the annual costs in this w monthly charge, if any, in the matrix tables.

please turn it into a

\section{School costs (or benefits)}

Please assume that the seven year old child is attending a public primary school and the 14 year old attending a public secondary school. Assume that the families live close to school and can walk, thus incurring no transport costs to school. Also ignore any occasional small voluntary contributions to school funds or charges for outings (such as going to a museum). Only include costs that parents must pay for books or equipment, or any benefits that families may receive for school meals or in terms of reduced costs for books. For the working lone parent with the preschool aged child only, the cost of the most common form of full-time. pre-school child-care should also be included.

Thank you very much for supplying this information. Please send your replies to SPRU by 31 May.

\section{CATEGORY 1; RECIPIENTS OF SOCIAL ASSISTANCE BENEFITS}

The following cases are to be estimated. All individuals have no income apart from the social assistance. child benefits, housing assistance, or non-contributory minimum pension relevant to people in their circumstances. In many cases only one form of social assistance would be applicable to any one family or individual. but where they might be entitled to more than one at a time the figure entered in the box labelled social assistance should represent the total payment available. If you have to make a decision about which benefit the individual or family might be receiving please add a note explaining your decision. 
Case 1 Single person, aged 17, living at home with parents

Case 2 Single person, aged 35, living alone

Case 3 Single person. aged 68, living alone

Case 4 Couple, no children. both aged 35

Case 5 Couple, no children, both aged 68

Case 6 Couple, both parents aged 35, with one child aged 2 years and 11 months

Case 7 Couple. both parents aged 35, with one child of 7 years

Case 8 Couple. both parents aged 35, with one child of 7 years and one child of 14 years

Case 9 Lone parent (female, separated or divorced, not widowed) aged 35. with one child of 2 years and 11 months

Case 10 Lone parent (female, separated or divorced, not widowed) aged 35, with one child of 7 years 


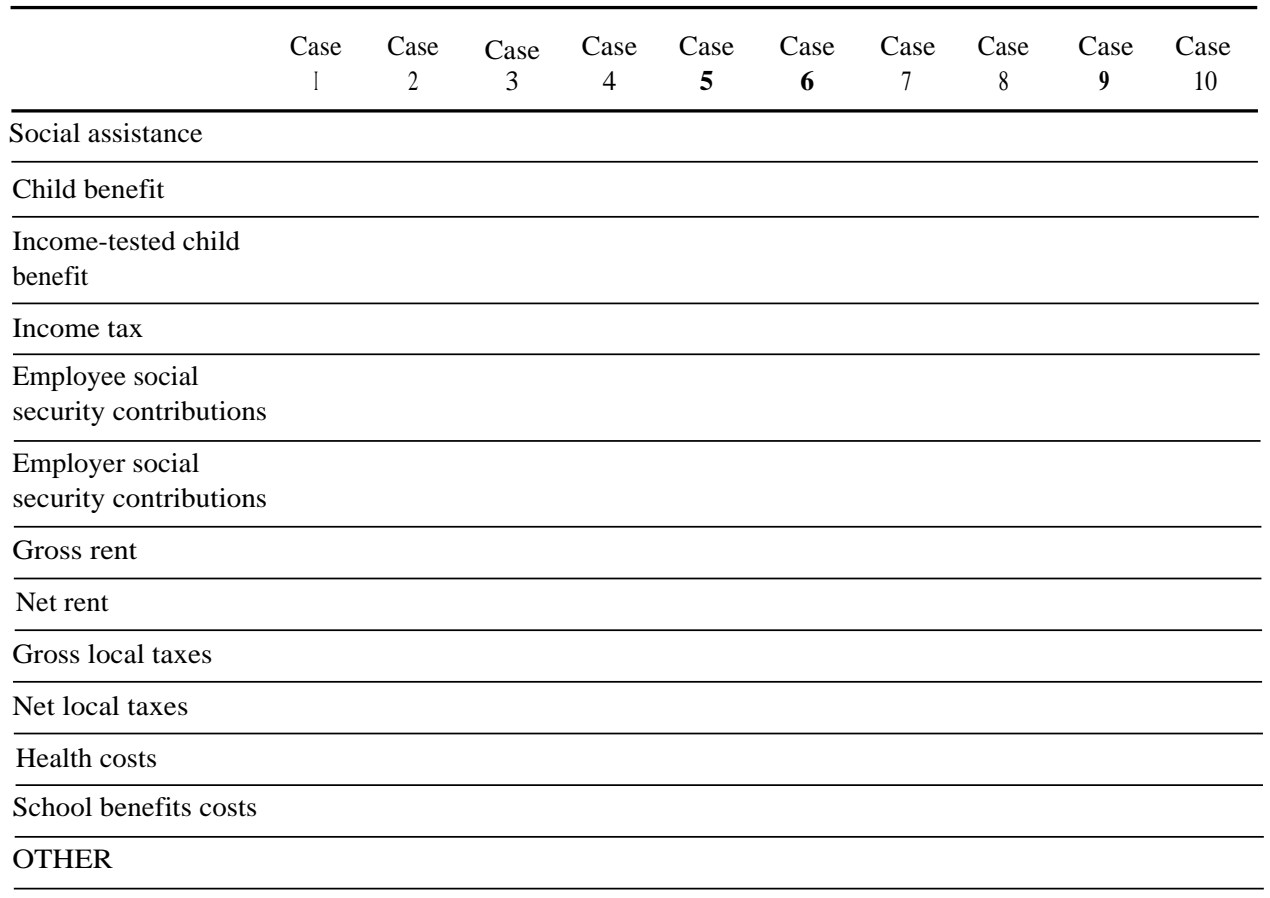

\section{CATEGORY 2: RECIPIENTS OF SOCIAL INSURANCE BENEFITS}

The following cases are to be estimated. All individuals only have income from the social insurance benefits relevant to people in their circumstances - they have no earnings or unearned income. Cases 1, 3, 5 and 6 are assumed to be unemployed and receiving the appropriate unemployment insurance benefits. Cases 2 and 4 are assumed to be receiving the insurance-based retirement pension appropriate to their circumstances. In addition, if their social insurance benefits are below the social assistance minimum, they receive supplementary social assistance benefits. if relevant.

Case I Single person, aged 35. living alone, unemployed for the past three months, when working he had received the average wages of male workers in the manufacturing sector and had paid continuous contributions

Case 2 Single person, aged 68, living alone, retired since 1989, when in work he had received the average male manufacturing wa ${ }^{g} \mathrm{e}$ and had made full contributions to the social insurance fund

Case 3 Couple, no children, both aged 35, the man has been unemployed for the past three months, when working he had received the average wages of male workers in the manufacturing sector and paid continuous contributions, the wife has never worked

Case 4 Couple, no children, both aged 68, the man has been retired since 1989, when in work he had received the average male manufacturing wage and had made full contributions to the social insurance fund. the wife has never worked

Case 5 Couple, with two children, both parents aged 35, one child of 7 years, one child of 14 years, the man has been unemployed for the past three months, when working he had received the average wages of male workers in the manufacturing sector and had paid continuous contributions, the wife has never worked

Case 6 Lone parent. aged 35, one child of 7 years, unemployed for the past three months, when working she had received the average wages of (male) workers in the manufacturing sector and paid continuous contributions 


\begin{tabular}{|c|c|c|c|c|c|c|}
\hline & $\begin{array}{c}\text { Case } \\
1\end{array}$ & $\begin{array}{c}\text { Case } \\
2\end{array}$ & $\begin{array}{c}\text { Case } \\
3\end{array}$ & $\begin{array}{c}\text { Case } \\
\mathbf{4}\end{array}$ & $\begin{array}{l}\text { Case } \\
\mathbf{S}\end{array}$ & $\begin{array}{c}\text { Case } \\
6\end{array}$ \\
\hline \multicolumn{7}{|c|}{$\begin{array}{l}\text { Social insurance } \\
\text { benefit }\end{array}$} \\
\hline \multicolumn{7}{|c|}{$\begin{array}{l}\text { Social assistance } \\
\text { benefits }\end{array}$} \\
\hline \multicolumn{7}{|c|}{ Child benefit } \\
\hline \multicolumn{7}{|c|}{$\begin{array}{l}\text { Income-tested child } \\
\text { benefit }\end{array}$} \\
\hline \multicolumn{7}{|c|}{ Income tax } \\
\hline \multicolumn{7}{|c|}{$\begin{array}{l}\text { Employee social } \\
\text { security contributions }\end{array}$} \\
\hline \multicolumn{7}{|c|}{$\begin{array}{l}\text { Employer social } \\
\text { security contributions }\end{array}$} \\
\hline \multicolumn{7}{|c|}{ Gross rent } \\
\hline \multicolumn{7}{|l|}{ Net rent } \\
\hline \multicolumn{7}{|c|}{ Gross local taxes } \\
\hline \multicolumn{7}{|c|}{ Net local taxes } \\
\hline \multicolumn{7}{|c|}{ Health costs } \\
\hline \multicolumn{7}{|c|}{$\begin{array}{l}\text { School benefits costs } \\
\text { per child }\end{array}$} \\
\hline OTHER & & & & & & \\
\hline
\end{tabular}

\section{CATEGORY 3: WORKING INDIVIDUALS AND FAMILIES}

Case I Single person, aged 35, living alone, receiving the average wages of male workers in the manufacturing sector

Case 2 Couple, no children, both aged 35, husband receiving the average wages of male workers in the manufacturing sector, wife not working

Case 3 Couple, with 1 child, both parents aged 35, child 2 years and 11 months, husband receiving the average wages of male workers in the manufacturing sector, wife not working

Case 4 Couple, with 1 child, both parents aged 35, one child of 7 years. husband receiving the average wages of male workers in the manufacturing sector, wife not working

Case 5 Couple, with 2 children, both parents aged 35, one child of 7 years, one child of 14 years, husband receiving the average wages of male workers in the manufacturing sector, wife not working

Case 6 Lone parent, aged 35, one child 2 years and 11 months, receiving the average wages of (male) workers in the manufacturing sector

Case 7 Lone parent, aged 35, one child of 7 years, receiving the average wages of (male) workers in the manufacturing sector 
CATEGORY 3: WORKING INDIVIDUALS AND FAMILIES

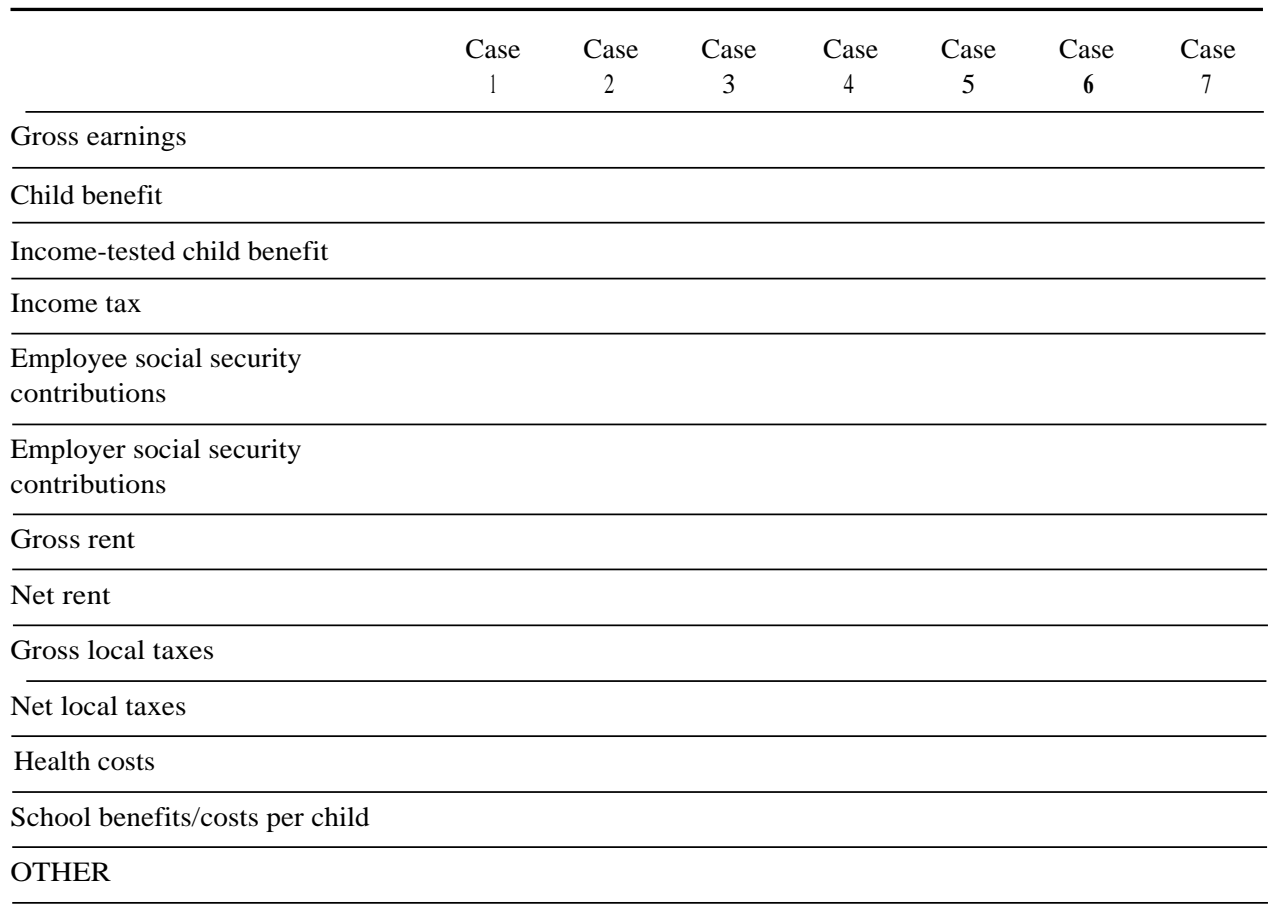


Other Research Reports available:

\begin{tabular}{|c|c|c|c|c|}
\hline No. & Title & \multicolumn{2}{|r|}{ ISBN } & Price \\
\hline 1. & Thirty Families: Their living standards in unemployment & 01 & 17616834 & $£ 6.65$ \\
\hline 2. & Disability household income \& expenditure & 0 & 7617555 & $£ 5.65$ \\
\hline 3. & Housing Benefit Reviews & 011 & 7618217 & $£ 16.50$ \\
\hline 4. & Social Security \& Community Care: The ease of the Invalid Care Allowance & 0 & 7618209 & $£ 9.70$ \\
\hline 5. & The Attendance Allowance Medical Examination: Monitoring consumer views & $0 \quad 11$ & 7618195 & $£ 5.50$ \\
\hline 6. & Lone Parent Families in the UK & $0 \quad 11$ & 7618683 & $£ 12.75$ \\
\hline 7. & Incomes In and Out of Work & $0 \quad 11$ & 7619108 & $£ .17 .20$ \\
\hline 8. & Working the Social Fund & 01 & 7619523 & $£ 9.00$ \\
\hline 9. & Evaluating the Social Fund & $0 \quad 1$ & 117619531 & $£ 22.00$ \\
\hline 10. & Benefits Agency National Customer Survey 1991 & 01 & 117619566 & $£ 36.00$ \\
\hline 1I. & Customer Perceptions of Resettlement Units & 01 & 117619760 & $£ 13.75$ \\
\hline 12. & Survey of Admissions to London Resettlement Units & 01 & 7619779 & $£ 8.00$ \\
\hline 13. & Researching the Disability Working Allowance Self Assessment Form & 01 & 7618349 & $£ 7.25$ \\
\hline 114. & Child Support Unit National Client Survey 1992 & 01 & 7620602 & $£ 30.00$ \\
\hline 15. & Preparing for Council Tax Benefit & 01 & 117620610 & $£ 5.65$ \\
\hline 16. & Contributions Agency Customer Satisfaction Survey 1992 & 01 & 7620645 & $£ 18.00$ \\
\hline 17. & Employers' Choice of Pension Schemes: report of a qualitative study & 01 & 117620734 & $£ 5.00$ \\
\hline 18. & GPs and IVB: A qualitative study of the role of GPs in the award of Invalidity & & & \\
\hline & Benefit & 01 & 117620777 & $£ 1.2 .00$ \\
\hline 19. & Invalidity Benefit: A Survey of Recipients & 01 & 117620874 & $£ 10.75$ \\
\hline 20. & Invalidity Benefit: A Longitudinal Survey of New Recipients & 01 & 117620882 & $£ 19.95$ \\
\hline 21. & Support for Children: A comparison of arrangements in fifteen countries & 01 & 7620890 & $£ 22.95$ \\
\hline 22. & $\begin{array}{l}\text { Pension Choices: A survey on personal pensions in comparison with other } \\
\text { pension options }\end{array}$ & 01 & 117620912 & $£ 18.95$ \\
\hline 23. & Crossing National Frontiers & 01 & 117621315 & $£ 17.75$ \\
\hline 24. & Statutory Sick Pay & 0 & 11762147 & $£ 23.75$ \\
\hline 25. & Lone Parents and Work & 0 & I1 $762148 x$ & $£ 12.95$ \\
\hline 26. & The Effects of Benefit on Housing Decisions & 0 & 117621579 & $£ 18.50$ \\
\hline 27. & Making a Claim for Disability Benefits & 0 & 117621625 & $£ 12.95$ \\
\hline 28. & Contributions Agency Customer Satisfaction Survey 1993 & 0 & 117622206 & $£ 20.00$ \\
\hline 29. & Child Support Agency National Client Satisfaction 1993 & 0 & 117622249 & $£ 33.00$ \\
\hline 30 . & Lone Mothers & 0 & 117622281 & $£ 16.75$ \\
\hline 31. & Educating Employers & 0 & 117622494 & $£ 8.50$ \\
\hline 32. & Employers and Family Credit & 0 & 117622729 & $£ 13.50$ \\
\hline 33. & Direct Payments from Income Support & 0 & 117622907 & $£ 16.50$ \\
\hline 34. & Incomes and Living Standards of Older People & 0 & 117622990 & $£ 24.95$ \\
\hline 35. & Choosing Advice on Benefits & 0 & I1 7623164 & $£ 13.95$ \\
\hline 36. & First-time Customers & 0 & 117623172 & $£ 25.00$ \\
\hline 37 & Contributions Agency Customer Satisfaction Survey 1994 & 0 & $11762339 \overline{3}$ & $£ 21.00$ \\
\hline 38. & Managing Money in Later Life & 0 & 117623407 & $£ 22.00$ \\
\hline 39. & Child Support Agency National Client Satisfaction 1994 & 0 & 117623415 & $£ 35.00$ \\
\hline 40. & Changes in Lone Parenthood & 0 & 117623490 & $£ 20.00$ \\
\hline 41. & Evaluation of Disability Living Allowance and Attendance Allowance & 0 & 117623512 & $£ 40.00$ \\
\hline 42. & War Pensions Agency Customer Satisfaction Survey 1994 & 0 & $11762358 X$ & $£ 18.00$ \\
\hline 43. & Paying for Rented Housing & 0 & 117623709 & $£ 19.00$ \\
\hline 44. & Resettlement Agency Customer Satisfaction Survey 1994 & 0 & 117623717 & $£ 16.00$ \\
\hline & Social Security Research Yearbook 1990-91 & 01 & 117617474 & $£ 8.00$ \\
\hline & Social Security Research Yearbook 1991--92 & 01 & 117618330 & $£ 12.00$ \\
\hline & Social Security Research Yearbook $1992 \cdots 93$ & 01 & $11762150 \mathrm{I}$ & $£ 13.75$ \\
\hline & Social Security Research Yearbook 1993-94 & 0 & 117623024 & $£ 16.50$ \\
\hline & Social Security Research Yearbook 1994-95 & 0 & 117623628 & $£ 20.00$ \\
\hline
\end{tabular}

Further information regarding the content of the above may be obtained from:

Department of Social Security

Attn. Keith Watson

Social Research Branch

Analytical Services Division 5

10th Floor. Adelphi

1-11 John Adam Street

London WC2N 6HT

Telephone: 01719628557 